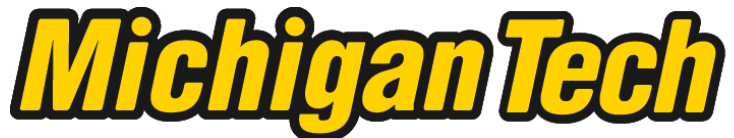 \\ Michigan Technological University Create the Future Digital Commons @ Michigan Tech
}

\section{Advanced Nanostructured Electro-Catalysts for Electricity Generation and Biorenewable Alcohol Conversion}

Zhiyong Zhang

Michigan Technological University

Follow this and additional works at: https://digitalcommons.mtu.edu/etds

Part of the Chemical Engineering Commons

Copyright 2012 Zhiyong Zhang

\section{Recommended Citation}

Zhang, Zhiyong, "Advanced Nanostructured Electro-Catalysts for Electricity Generation and Biorenewable Alcohol Conversion", Dissertation, Michigan Technological University, 2012.

https://doi.org/10.37099/mtu.dc.etds/458

Follow this and additional works at: https://digitalcommons.mtu.edu/etds

Part of the Chemical Engineering Commons 


\title{
ADVANCED NANOSTRUCTURED ELECTRO-CATALYSTS FOR ELECTRICITY GENERATION AND BIORENEWABLE ALCOHOL CONVERSION
}

By

Zhiyong Zhang

\begin{abstract}
A DISSERTATION
Submitted in partial fulfillment of the requirements for the degree of

DOCTOR OF PHILOSOPHY

(Chemical Engineering)
\end{abstract}

MICHIGAN TECHNOLOGICAL UNIVERSITY

2012

(C) 2012 Zhiyong Zhang 
This dissertation, “Advanced Nanostructured Electro-Catalysts for Electricity Generation and Biorenewable Alcohol Conversion," is hereby approved in partial fulfillment of the requirements for the Degree of DOCTOR OF PHILOSOPHY IN CHEMICAL ENGINEERING.

Department of Chemical Engineering

Signature:

Dissertation Advisor

Dr. Wenzhen Li

Department Chair

Dr. Komar Kawatra

Date 


\section{Table of Contents}

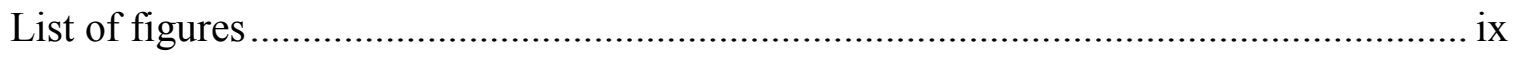

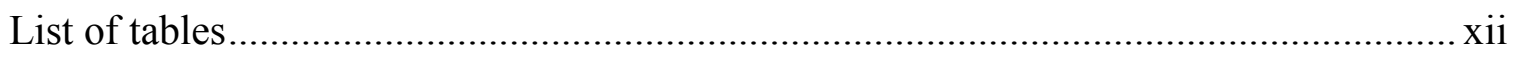

Preface

Publications at Michigan Technological University ..................................................... xiv

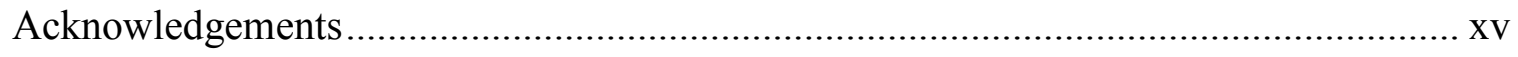

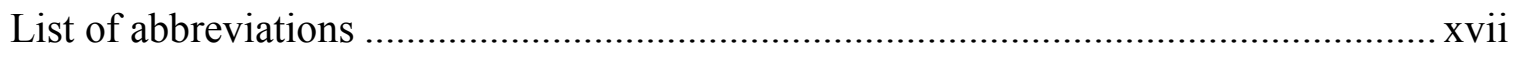

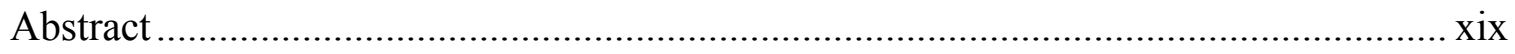

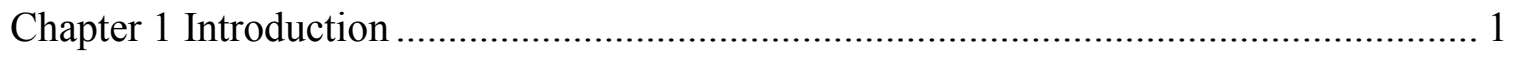

1.1 Energy: A grand challenge in $21^{\text {st }}$ century........................................................ 1

1.2 Fuel cells: A clean electrical energy technology ................................................... 1

1.3 Bioalcohols (ethanol and glycerol): Promising liquid fules for fuel cells ................ 2

1.4 Chemical production: Urgent need to develop green and sustainable electrocatalytic routes from biomass resources .................................................................... 4

1.5 Nanostructured electro-catalysts: Great opportunities to improve fuel cell

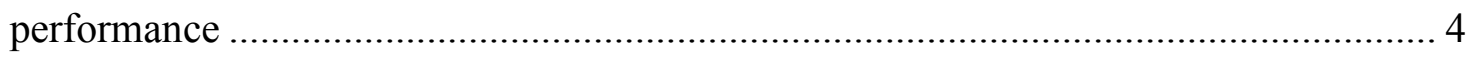

1.6 Advanced wet-chemistry synthesis methods: Essential to accurate control over

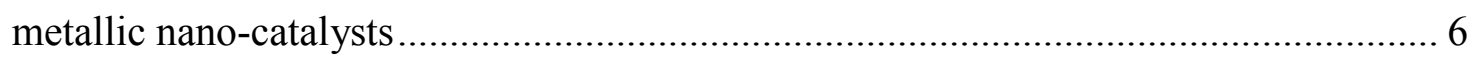

1.7 Goal and significance of my Ph.D research...................................................... 7

Chapter 2 General Experimental.......................................................................... 9

2.1 Organic solution phase synthesis method ........................................................... 9

2.1.1 Chemicals ............................................................................................... 9

2.1.2 Synthesis system and typical catalyst preparation procedures …….................. 9 


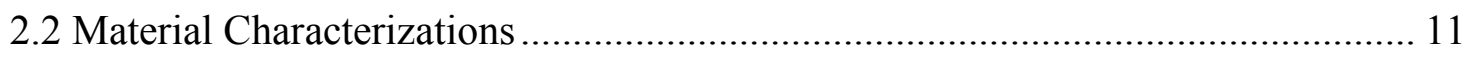

2.2.1 Transmission electron microscopy (TEM) …………………………............ 11

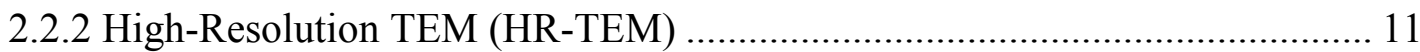

2.2.3 High angle annular dark field (HAADF) scanning transmission electron

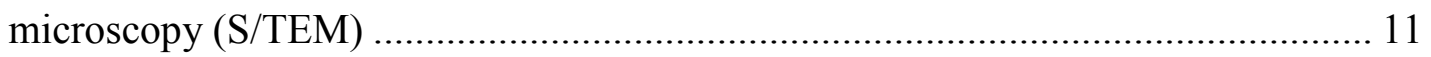

2.2.4 X-ray photoelectron spectroscopy (XPS) ……………………………….... 12

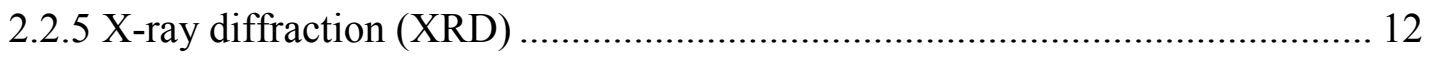

2.2.6 Inductively coupled plasma atomic emission spectroscopy (ICP-AES).......... 13

2.2.7 Thermal gravimetric analysis (TGA) ......................................................... 13

2.3 Electro-chemical investigation...................................................................... 13

2.3.1 Electro-chemical tests in half cell ............................................................. 13

2.4.2 Anion-exchange membrane fuel cell (AEMFC) test ......................................... 18

Chapter 3 Synthesis of Pt-Fe nanowires as highly durable catalysts for oxygen reduction

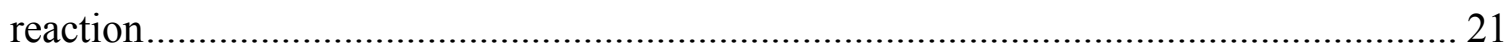

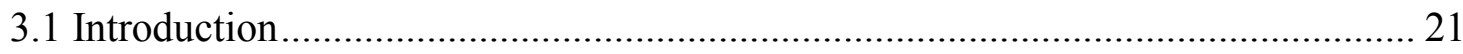

3.1.1 Operation mechanism and thermodynamics of $\mathrm{H}_{2} / \mathrm{O}_{2}$-fed PEMFC ................ 21

3.1.2 Oxygen reduction reaction (ORR) and the challenges in the durability of cathode catalyst ............................................................................................... 22

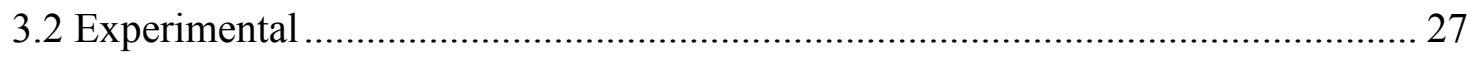

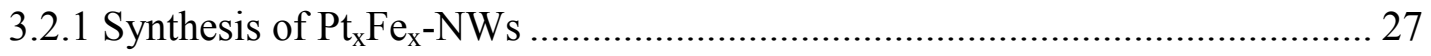

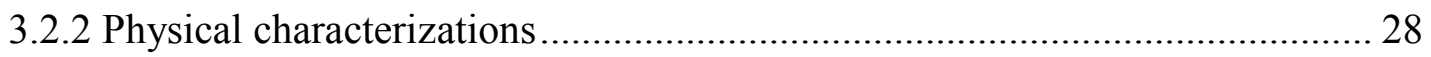

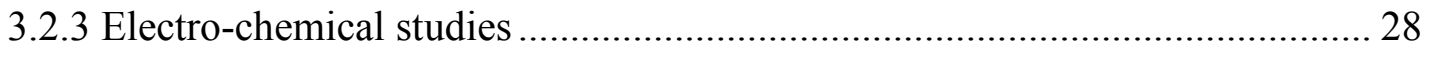

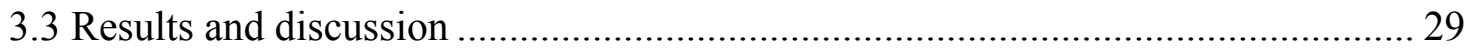

3.3.1 Physical characterizations .......................................................................... 29

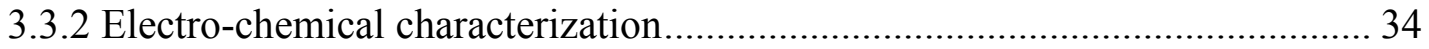




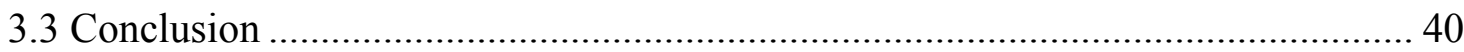

Chapter 4 Pd-Fe nanoleaves as electro-catalysts for ORR in alkaline electrolyte............ 41

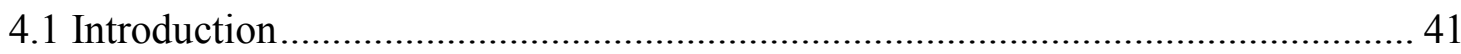

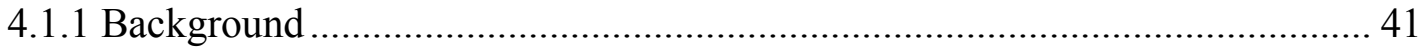

4.1.2 Thermodynamics in $\mathrm{H}_{2} / \mathrm{O}_{2}$ AEMFC .......................................................... 42

4.1.3 ORR mechanism in alkaline electrolyte ...................................................... 42

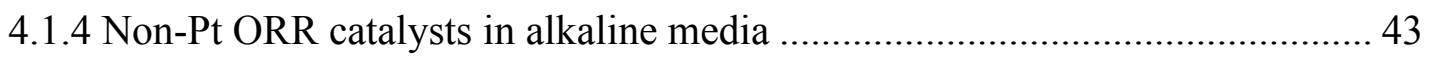

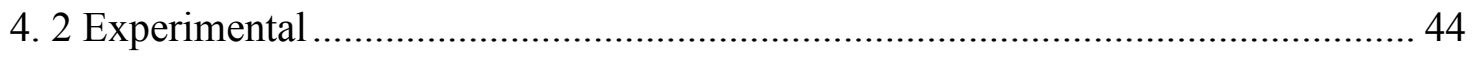

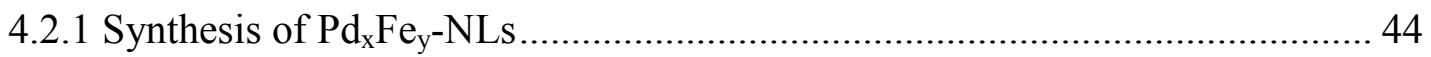

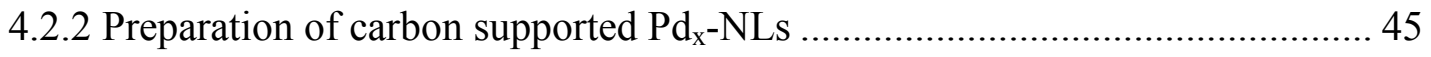

4.2.3 Preparation of carbon supported Pd............................................................... 45

4.2.4 Physical characterizations ............................................................................ 46

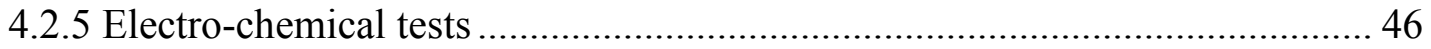

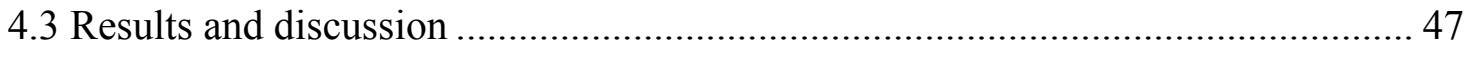

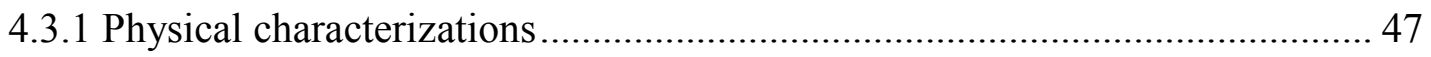

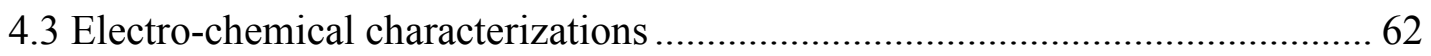

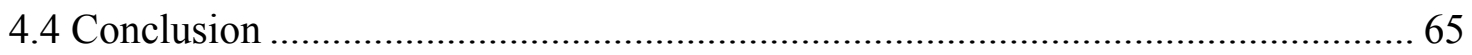

Chapter 5 Pd-Ni electro-catalysts for efficient ethanol oxidation reaction in alkaline

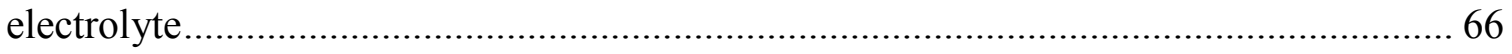

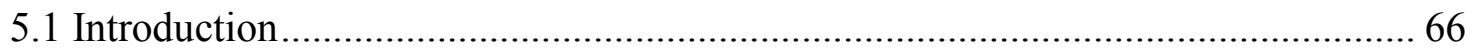

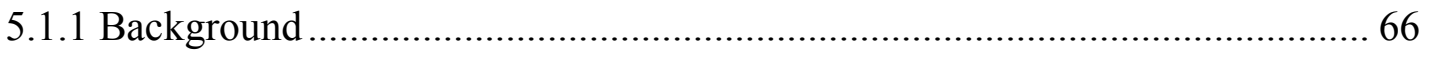

5.1.2 Pd-based ethanol electro-oxidation catalysts .................................................... 68

5.1.3 Mechanism of ethanol electro-oxidation on Pd catalyst ................................... 69

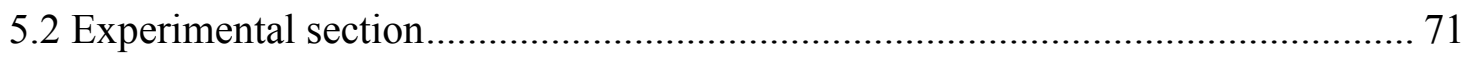

5.2.1 Preparation of $\mathrm{Pd} / \mathrm{C}, \mathrm{Pd}_{\mathrm{x}} \mathrm{Ni}_{\mathrm{y}} / \mathrm{C}$, and $\mathrm{Pd}_{1} \mathrm{Ni}_{1} / \mathrm{C}-\mathrm{NaBH}_{4}$ catalysts ..................... 71 


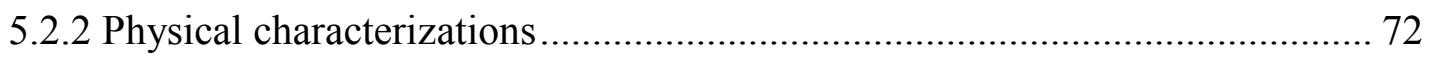

5.2.3 Electro-chemical characterizations ................................................................ 72

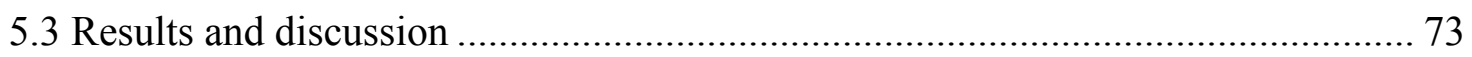

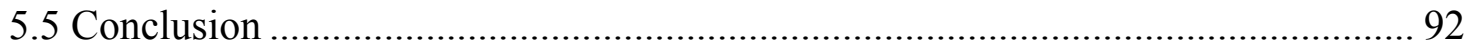

Chapter $6 \mathrm{Au} / \mathrm{C}$ as anode catalyst for anion-exchange membrane-direct glycerol fuel cell

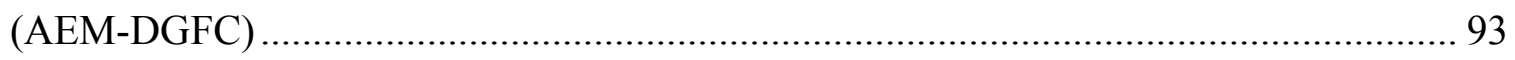

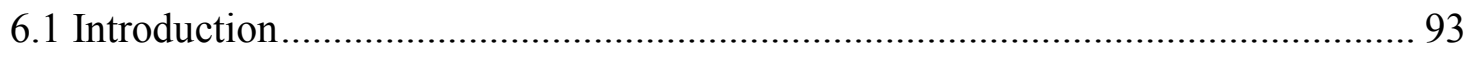

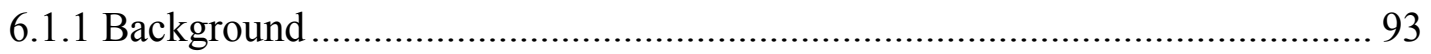

6.1.2 Recent development of anion-exchange membrane direct glycerol fuel cells

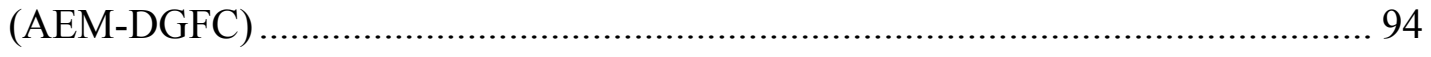

6.1.3 Glycerol electro-oxidation mechanism in alkaline electrolyte ........................ 95

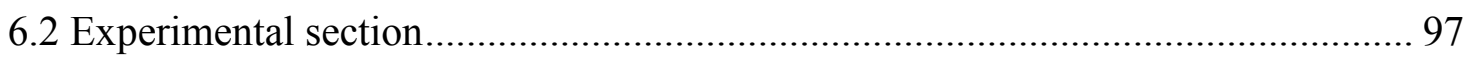

6.2.1 Preparation of $\mathrm{Au} / \mathrm{C}$ catalyst .......................................................................... 97

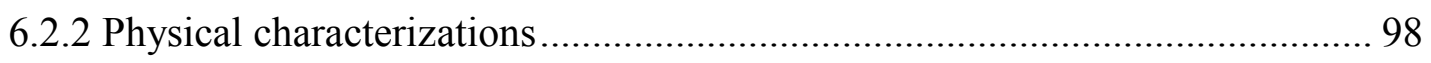

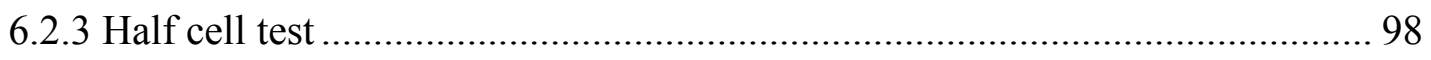

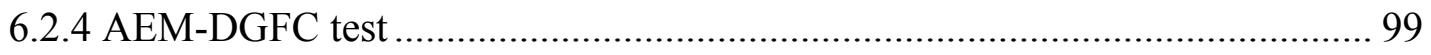

6.2.5 Faradic efficiency analysis and product analysis............................................. 99

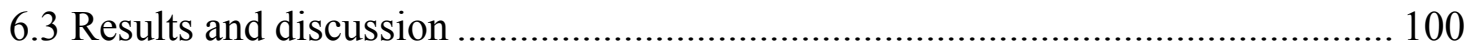

6.3.1 Physical characterizations ........................................................................... 100

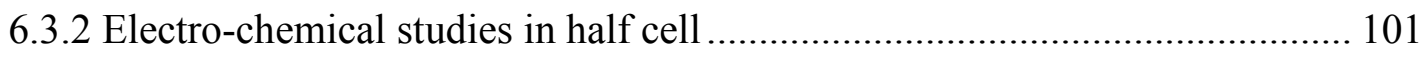

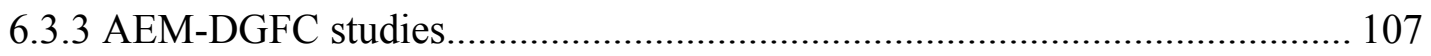

6.3.3 Products analysis and Faradic efficiency investigation ................................. 112

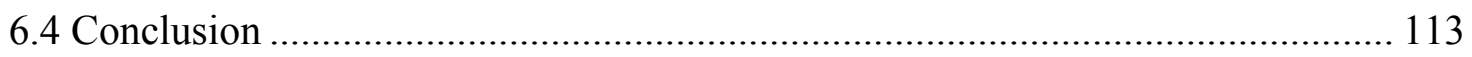

Chapter 7 Electro-catalytic oxidation of glycerol on $\mathrm{Pt} / \mathrm{C}$ in anion-exchange membrane fuel cell: Cogeneration of electricity and valuable chemicals ........................................ 115 


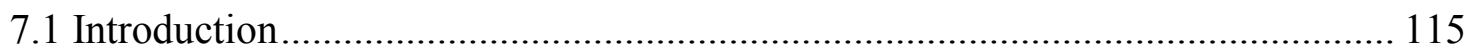

7.1.1 Biomass derived glycerol....................................................................... 115

7.1.2 Selective heterogeneous catalytic oxidation of glycerol............................... 116

7.1.3 Relationship between heterogeneous catalysis and fuel cell reactions.......... 117

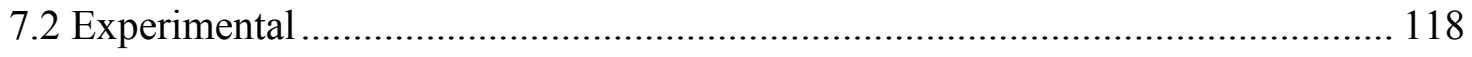

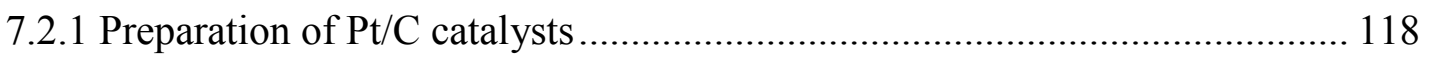

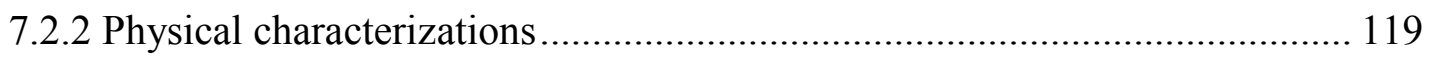

7.2.3 MEA fabrication and electro-oxidation of glycerol in AEM-DGFC ............. 119

7.2.4 Electro-oxidation of glycerol in half cell with online sample collection system

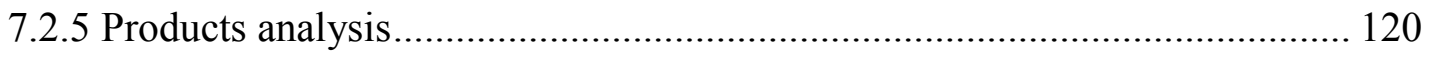

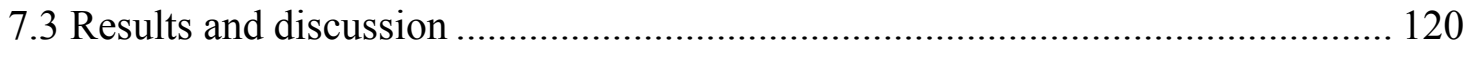

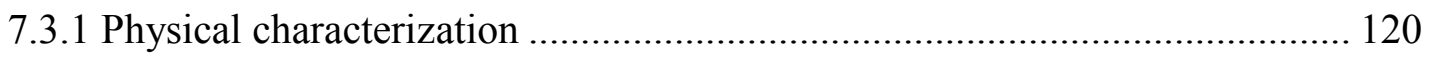

7.3.2 Electricity generation performance of anion exchange membrane direct

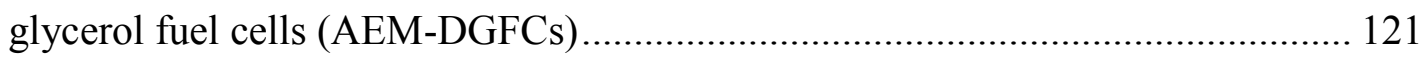

7.3.3 Electro-catalytic oxidation of glycerol in AEM-DGFCs ................................ 123

7.3.4 Reaction sequence of electro-oxidation of glycerol on $\mathrm{Pt} / \mathrm{C}$ in half cell ....... 132

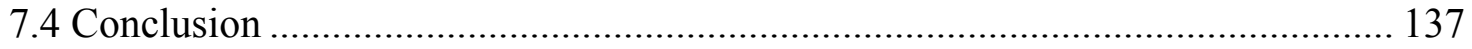

Chapter 8 Potential regulated electro-oxidation of glycerol to value-added products on supported Au catalysts ......................................................................................... 138

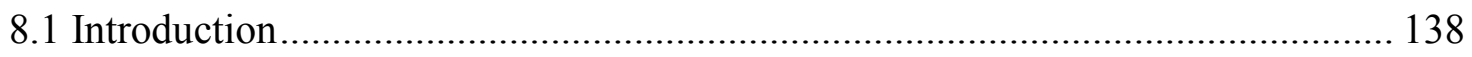

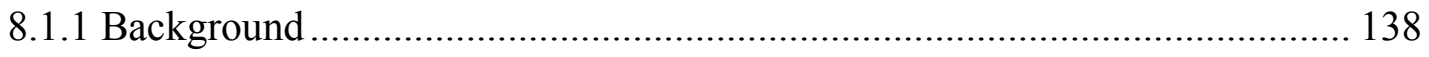

8.1.2 Glycerol oxidation on Au-based catalyst.................................................... 139

8.1.3 Cogeneration of value-added chemicals and electricity in Au-anode AEM-

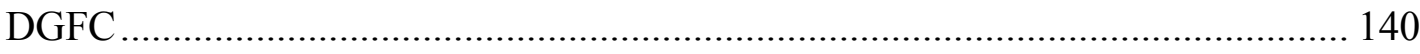




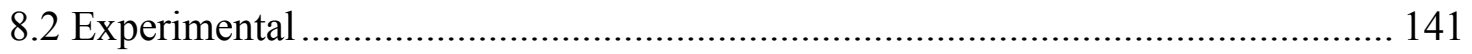

8.2.1 Preparation of $\mathrm{Au} / \mathrm{C}$ and $\mathrm{Au} / \mathrm{CNT}$ catalysts................................................ 141

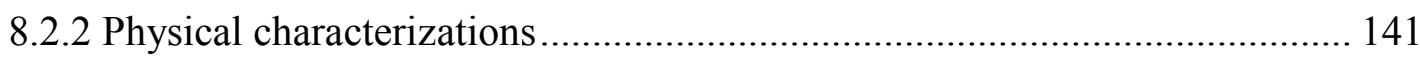

8.2.3 Electro-catalytic oxidation of glycerol........................................................ 142

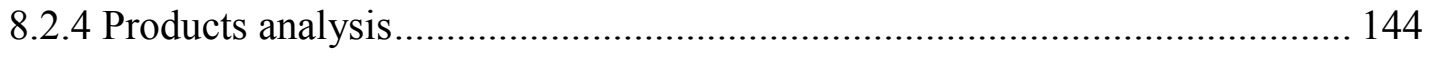

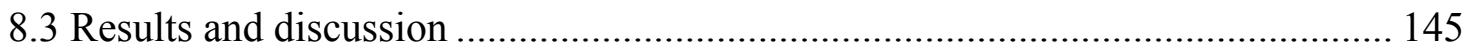

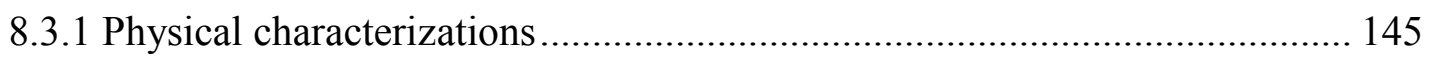

8.3.2 Potential controlled selective electro-oxidation of glycerol to tartronate and

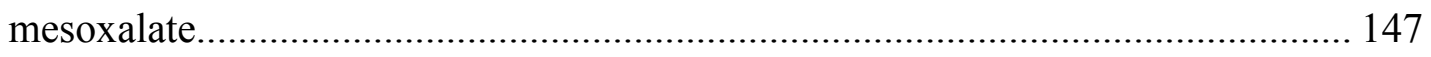

8.3.3 Selective electro-oxidation of glycerol to glycolate ....................................... 151

8.3.4 Reaction mechanism of the electro-catalytic oxidation of glycerol............... 156

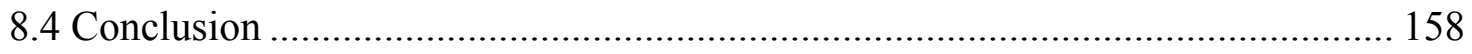

Chapter 9 Recommendations and future work........................................................ 159

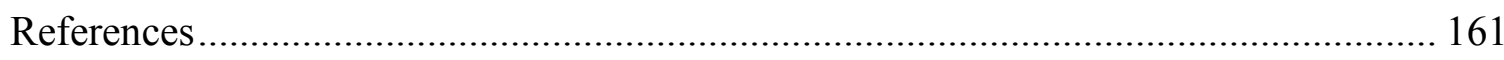

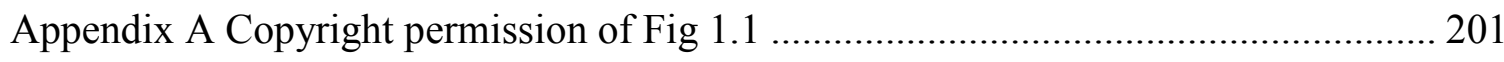

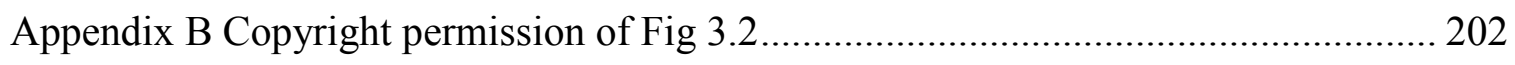

Appendix C Copyright permission of Fig. 3.3 …………………………………….... 204

Appendix D Copyright permission of Fig. 4.1 ............................................................. 206

Appendix E Copyright permission of Fig. 6.1 ……………......................................... 208

Appendix F Copyright permission of Fig. 6.2 ............................................................. 210

Appendix G Copyright permission of Chapter 3 ....................................................... 212

Appendix H Copyright permission of Chapter 4 ……………..................................... 214

Appendix I Copyright permission of Chapter 5 and 6 ................................................ 216

Appendix J Copyright permission of Chapter 7 ...................................................... 218

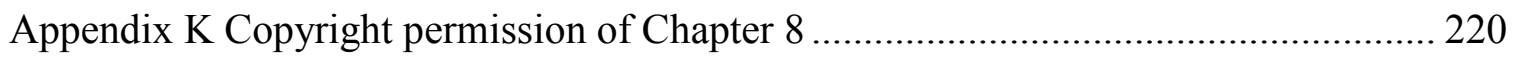




\section{List of figures}

Fig. 1.1 U.S. energy flow (2010), unit is given in quad, which is $10^{15}$ BTU .................. 2

Fig. 2.1 Experimental setup for the organic solution phase synthesis of nanocatalysts... 10

Fig. 2.2 half cell tests setups: (a) a three-compartment-cell with a reversible hydrogen . 14

Fig. 2.3 Scheme of online products collection system.............................................. 17

Fig. 3.1 Schematic drawing of a proton-exchange membrane fuel cell......................... 22

Fig. 3.2 Proposed schemes for oxygen reduction reaction in acid media ....................... 23

Fig. 3.3 Proposed mechanisms of instability of Pt nanoparticles in low temperature ...... 25

Fig. 3.4 (a) XRD patterns of $\mathrm{Pt}_{\mathrm{x}} \mathrm{Fe}_{\mathrm{y}}-\mathrm{NWs}(1: 1,2: 1$, and 5:1) and commercial Pt/C...... 31

Fig. 3.5 TEM images of (a) $\mathrm{Pt}_{1} \mathrm{Fe}_{1}-\mathrm{NW}$; (b) $\mathrm{Pt}_{2} \mathrm{Fe}_{1}-\mathrm{NW}$; and (c) $\mathrm{Pt}_{5} \mathrm{Fe}_{1}-\mathrm{NW} \ldots \ldots \ldots \ldots \ldots . . . . . . .33$

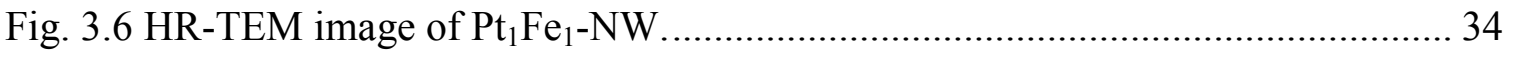

Fig. 3.7 Cyclic voltammograms of $\mathrm{Pt}_{\mathrm{x}} \mathrm{Fe}_{\mathrm{y}}-\mathrm{NWs}((\mathrm{a})-(\mathrm{c}))$ and the $\mathrm{Pt} / \mathrm{C}(\mathrm{d})$ catalysts ..... 37

Fig. 3.8 Accelerated durability tests on $\mathrm{Pt}_{\mathrm{x}} \mathrm{Fe}_{\mathrm{y}}-\mathrm{NW}(1: 1,2: 1,5: 1) / \mathrm{C}$ and $\mathrm{Pt} / \mathrm{C}$ catalysts .. 38

Fig. 3.9 ORR polarization curves of $\mathrm{Pt}_{1} \mathrm{Fe}_{1}-\mathrm{NWs}$ and commercial $\mathrm{Pt} / \mathrm{C}$ catalysts .......... 39

Fig. 4.1 Proposed schemes for oxygen reduction reaction in alkaline media .................. 42

Fig. 4.2 (a) XRD patterns of $\mathrm{Pd} / \mathrm{C}$ and $\mathrm{Pd}_{\mathrm{x}} \mathrm{Fe}_{\mathrm{y}}-\mathrm{NL} / \mathrm{C}$ samples with different $\mathrm{PdFe}$........ 49

Fig. 4.3 TEM images of the PdFe-NLs, (a,b) $\mathrm{Pd}_{1} \mathrm{Fe}_{1}-\mathrm{NLs},(\mathrm{c}, \mathrm{d}) \mathrm{Pd}_{2} \mathrm{Fe}_{1}-\mathrm{NLs}, \ldots \ldots \ldots \ldots \ldots . . . . . .51$

Fig. 4.4 Morphology of $\mathrm{Pd}_{1} \mathrm{Fe}_{1}-\mathrm{NLs} / \mathrm{C}$ : (a) TEM image, (b) HAADF-STEM image...... 53

Fig. 4.5 XPS spectrum of $\mathrm{Pd}_{1}-\mathrm{NL} / \mathrm{C}$ (a) Survey scan, (b) Narrow scan of Fe................. 55

Fig. 4.6 TEM images of the PdFe-NWs prepared with different conditions ................... 57

Fig. 4.7 Morphology of $\mathrm{Pd}_{1}-\mathrm{NL} / \mathrm{C}\left(\mathrm{Pd}_{1} \mathrm{Fe}_{1}-\mathrm{NL} / \mathrm{C}\right.$ after acid treatment): (a) TEM.......... 58 
Fig. 4.8 XPS spectra of $\mathrm{Pd}_{1}-\mathrm{NL} / \mathrm{C}$ : (a) survey scan, (b) narrow scan of $\mathrm{Fe}$, (c) narrow... 61

Fig. 4.9 TGA curves and temperature plots (inserted) of $\mathrm{Pd}_{1} \mathrm{Fe}_{1}-\mathrm{NL} / \mathrm{C}$ and. 61

Fig. 4.10 Cyclic voltammograms of commercial Pt/C, Pd/C (self-prepared ................... 62

Fig. 4.11 ORR polarization curves of commercial Pt/C, $\mathrm{Pd} / \mathrm{C}$ (self-prepared by............ 63

Fig. 5.1 Thermogravimetric analysis plot and temperature plot (inserted) of $\mathrm{Pd} / \mathrm{C}$........ 74

Fig. 5.2 XRD patterns of (a) $\mathrm{Pd} / \mathrm{C}$ and $\mathrm{Pd}_{\mathrm{x}} \mathrm{Ni}_{\mathrm{y}} / \mathrm{C}$ samples with different $\mathrm{Pd}: \mathrm{Ni}$.............. 77

Fig. 5.3 TEM images of (a) $\mathrm{Pd} / \mathrm{C}$, (b) $\mathrm{Pd}_{4} \mathrm{Ni}_{1} / \mathrm{C}$, (c) $\mathrm{Pd}_{2} \mathrm{Ni}_{1} / \mathrm{C}$, (d) $\mathrm{Pd}_{1} \mathrm{Ni}_{1} / \mathrm{C}, \ldots \ldots \ldots \ldots \ldots . . . . . .80$

Fig. 5.4 HR-TEM images of (a) $\mathrm{Pd}_{1} \mathrm{Ni}_{1} / \mathrm{C}$ and (b) $\mathrm{Pd}_{1} \mathrm{Ni}_{1} / \mathrm{C}-\mathrm{NaBH}_{4}$, both showing ....... 80

Fig. 5.5 Cyclic voltammograms of (a) $\mathrm{Pd} / \mathrm{C}$ and $\mathrm{Pd}_{\mathrm{x}} \mathrm{Ni}_{\mathrm{y}} / \mathrm{C}$ prepared by the................... 82

Fig. 5.6 Cyclic voltammograms of ethanol oxidation reaction on (a) $\mathrm{Pd} / \mathrm{C}$ and ............. 83

Fig. 5.7 Quasi-steady state linear scan voltammograms of ethanol oxidation reaction.... 88

Fig. 5.8 Tafel plots for ethanol electro-oxidation on $\mathrm{Pd} / \mathrm{C}, \mathrm{Pd}_{\mathrm{x}} \mathrm{Ni}_{\mathrm{y}} / \mathrm{C}$, and .................... 89

Fig. 5.9 Chronoamperometry curves on $\mathrm{Pd} / \mathrm{C}$ and $\mathrm{Pd}_{\mathrm{x}} \mathrm{Ni}_{\mathrm{y}} / \mathrm{C}$ and $\mathrm{Pd}_{1} \mathrm{Ni}_{1} / \mathrm{C}-\mathrm{NaBH}_{4} \ldots \ldots . . .91$

Fig. 6.1 Reaction mechanisms identified for $\mathrm{Pt} / \mathrm{C}, \mathrm{Pd} / \mathrm{C}$, and $\mathrm{Au} / \mathrm{C}$ for glycerol........... 96

Fig. 6.2 The glycerol oxidation mechanism on Au and Pt electrodes in alkaline media.. 97

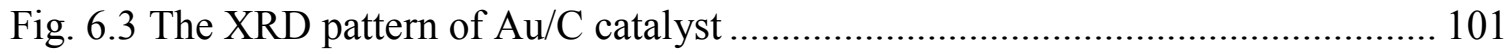

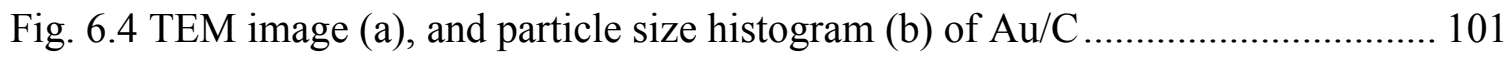

Fig. 6.5 Cyclic voltammograms of $\mathrm{Au} / \mathrm{C}$ in $1.0 \mathrm{M} \mathrm{KOH}, 50 \mathrm{mV} \mathrm{s}^{-1}$ (a), $1.0 \mathrm{M} \mathrm{KOH} \ldots 106$

Fig. 6.6 Polarization curves of an AEM-DGFC at operation temperature of............... 109

Fig. 6.7 Polarization curves before and after the durability test (a), and the relative.... 111

Fig. 7.1 Transesterification of vegetable oils or fats to biodiesel and byproduct ........... 116

Fig. 7.2 Morphology characterizations: (a) XRD pattern, (b) TEM image, .................. 122

Fig. 7.3 Polarization curves of AEM-DGFC at operation temperature ....................... 123 
Fig. 7.4 (a) Electricity generation and products distribution ..................................... 125

Fig. 7.5 Electricity generation and product distribution from electro-catalytic ............ 129

Fig. 7.6 Electricity generation and product distribution from electro-catalytic.............. 131

Fig. 7.7 Reusability results of Pt/C catalyst in AEM-DGFC ........................................ 132

Fig. 7.8 Electro-catalytic oxidation of glycerol on Pt/C catalyst................................... 134

Fig. 8.1 Schematic illustration of the anion exchange membrane-based....................... 143

Fig. 8.2 XRD patterns of $\mathrm{Au} / \mathrm{C}$ and $\mathrm{Au} / \mathrm{CNT}$ catalysts.............................................. 146

Fig. 8.3 The TEM images of Au/C and Au/CNT ((a) and (c)), .................................. 146

Fig. 8.4 Electro-oxidation of glycerol (2.0 M KOH + 1.0 M glycerol) on Au/C .......... 147

Fig. 8.5 Electro-oxidation of glycerol (2.0 M KOH + 1.0 M glycerol) on Au/C .......... 149

Fig. 8.6 Initial glycerol concentration effects, at the applied potential of ...................... 150

Fig. 8.7 Electro-oxidation of glycerol (2.0 M KOH + 1.0 M glycerol) on Au/CNT ..... 153

Fig. 8.8 Electro-oxidation of glycolate $(1.0 \mathrm{M})$ on Au/CNT catalyst under different ... 153

Fig. 8.9 Electro-oxidation of glycerol (2.0 M KOH + 1.0 M glycerol) on Au/CNT ...... 155

Fig. 8.10 Proposed reaction pathway for electro-oxidation of glycerol on Au catalyst . 157 


\section{List of tables}

Table 4.1 Atomic composition, length, diameter, and lattice parameter ....................... 48

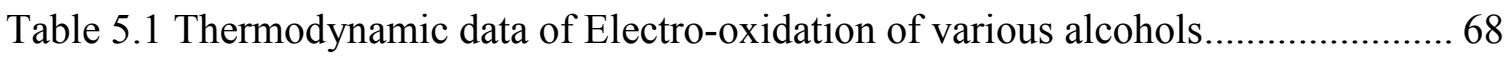

Table 5.2 Summary of physical properties of $\mathrm{Pd} / \mathrm{C}, \mathrm{Pd}_{\mathrm{x}} \mathrm{Ni}_{\mathrm{y}} / \mathrm{C}$, and, $\mathrm{Pd}_{1} \mathrm{Ni}_{1} / \mathrm{C}$ catalysts .. 74

Table 5.3 Electro-chemcial surface area (ECSA), mass activity, and specific activity.... 84

Table 5.4 Onset potential, Tafel slope and exchange current density of EOR ................ 88

Table 5.5 EOR mass activity (MA) at the end of 10000-second chronoamperometry..... 91

Table 6.1 Product selectivity and Faradic efficiency $\left(\eta_{\mathrm{e}}\right)$ of an AEM-DGFC ................ 112

Table 7.1 Electro-oxidation of glycerol over Pt/C in AEM-DGFC ............................. 124

Table 7.2 Electro-oxidation of glycerol over Pt/C in AEM-DGFC .............................. 127

Table 8.1 Electro-oxidation of glycerol on $\mathrm{Au} / \mathrm{CNT}$ at $1.6 \mathrm{~V}$ for 3 hours..................... 154 


\section{Preface}

Chapter 3 is an article I published in Nanotechnology, Volume 22, Issue 1, 015602. I did the catalyst synthesis, XRD analysis, and the electro-chemical tests. Drs. Meijun Li and Zili Wu did the TEM analysis.

Chapter 4 is an article I published in Chemistry of Materials, Volume 23, Issue 6, 15701577. I did the catalyst synthesis, XRD analysis, and the electro-chemical tests. Drs. Kai Sun and Karren L. More did the HR-TEM analysis. Dr. Zili Wu is the co-PI of this project and hosted my research in Oak Ridge National Lab.

Chapter 5 is an article I published in International Journal of Hydrogen Energy, Volume 36, Issue 20, 12686-12697. I did the catalyst synthesis, XRD and TEM analysis, and the electro-chemical tests. Le Xin assisted me in the synthesis and electro-chemical tests. Dr. Kai Sun did the HR-TEM tests.

Chapter 6 is an article I published in International Journal of Hydrogen Energy, Volume 37, Issue 11, 9393-9401. I did the synthesis, XRD and TEM analysis, the half cell tests, the durability test, and the Faradic efficient analysis. Le Xin did the performance tests and the product analysis.

Chapter 7 is an article I published in Applied Catalysis B: Environmental, Volume 119120, 40-48. I did all the experiments, with Le Xin's assistance.

Chapter 8 contains some data I originally published in Green Chemistry, DOI: 10.1039/C2GC35505A. I did all the experiments, with the assistance of Le Xin and Zhichao Wang. Ji Qi drew the scheme of the electro-catalytic cell in Fig. 8.1 (b).

All my Ph.D research was advised by Dr. Wenzhen Li. The results were discussed with all the co-authors before publication. 


\section{Publications at Michigan Technological University}

(1) Olumide Winjobi, Zhiyong Zhang, Changhai Liang, Wenzhen Li, Carbon nanotube supported platinum-palladium nanoparticles for formic acid oxidation, Electrochimica Acta, 2010, 13, 4217

(2) Zhiyong Zhang, Meijun Li, Zili Wu, Wenzhen Li, Ultra-thin PtFe-nanowire as durable electrocatalysts for fuel cells, Nanotechnology, 2011, 22, 015602

(3) Zhiyong Zhang, Karren L. More, Kai Sun, Zili Wu, Wenzhen Li, Preparation and characterization of PdFe nanoleaves as electrocatalysts for oxygen reduction reaction, Chemistry of Materials, 2011, 23, 1570

(4) Zhiyong Zhang, Le Xin, Kai Sun, Wenzhen Li, Pd-Ni electrocatalysts for efficient ethanol oxidation reaction in alkaline electrolyte, International Journal of Hydrogen Energy, 2011, 36, 12686

(5) Zhiyong Zhang, Le Xin, Wenzhen Li, Electrocatalytic oxidation of glycerol on $P t / C$ in anion-exchange membrane fuel cell: Cogeneration of electricity and valuable chemicals, Appied Catalysis B: Environmental 2012, 119-120, 40

(6) Zhiyong Zhang, Le Xin, Wenzhen Li, Supported gold nanoparticles as anode catalyst for anion exchange membrane-direct glycerol fuel cell (AEM-DGFC), International Journal of Hydrogen Energy, 2012, 37, 9393

(7) Le Xin, Zhiyong Zhang, Zhichao Wang, Wenzhen Li, Simultaneous Generation of Mesoxalic Acid and Electricity from Glycerol on Au Anode Catalyst in Anion Exchange Membrane Fuel Cells, ChemCatChem, doi:10.1002/cctc. 201200017

(8) Le Xin, Zhiyong Zhang, Ji Qi, David Chadderdon, Wenzhen Li, Electrocatalytic oxidation of ethylene glycol (EG) on supported Pt and Au catalysts in alkaline media: Reaction pathway investigation in three-electrode cell and fuel cell reactors, Appied Catalysis B: Environmental, 2012, 125, 85

(9) Zhiyong Zhang, Le Xin, Ji Qi, Zhichao Wang, Wenzhen Li, Selective electroconversion of glycerol to glycolate on carbon nanotube supported gold catalyst, Green Chemistry, 2012, 14, 2150 


\section{Acknowledgements}

Graduate study is a long and intense competition. I would not finish it without the help from many people. First and foremost, I would like to express my deepest gratitude to my dissertation advisor, Dr. Wenzhen Li, for his constant encouragement, guidance, and financial support (The NSF-CBET 1032547 and ACS-PRF grants partially supported my $\mathrm{Ph} . \mathrm{D}$ study and gratefully acknowledged). His serious attitude and persistently pursuing work ethic strongly impressed me and guided me on the road of my research career.

I would also like to thank Drs. Yun Hang Hu, Jason M. Keith (Mississippi State University), and Tony N. Rogers for serving on my dissertation committee, and spending time reading and correcting my dissertation. I also appreciate Drs. Michael E. Mullins and Jason M. Keith for sharing their labs.

I would also like to express my thanks to our collaborators. Thank you to Dr. Kai Sun from University of Michigan for his help on the HR-TEM analysis. Thank you to Drs. Zili Wu, Meijun Li and Karren L. More from Oak Ridge National Lab for their helps on material morphology analysis. Thank you to Dr. Bowen Li for his help on the ICP-AES analysis. Thanks Drs. David R. Shonnard and Susan T. Bagley, and their students for their help on the HPLC analysis.

I want to extend my warm thanks to Christine M. Abramson, David W. Caspary, Timothy P. Gasperich, Jerry A. Norkol, Alexis E. Snell, and David A. Zei for their help and support in lab setting up and operations. Thanks also go to Edward A. Latitila for his discussion on XRD analysis, and Owen P. Mills for his instruction on TEM operations.

Thanks to the faculty and staff that I have worked with during my graduate study for help me fulfill my duty as a teaching assistant. They are Drs. Daniel A. Crowl, Faith A. Morrison, and David R. Shonnard, and Mr. David W. Caspary. 
I would also like to express my pleasure of working with the nice members in Dr. Li's group, David J. Chadderdon, Le Xin, Ji Qi, Brandon S. Spigarelli, Kayla M. Warsko, and Zhichao Wang. I thank to them for their constant support and discussion with me.

Finally, I would like to express my deep thanks to my mom and dad for their long time support and encouragement in my life. Also, special thanks to my wife, Jing, for her endless love and support to me. 


\section{List of abbreviations}

\begin{tabular}{|c|c|}
\hline AEM & Anion-exchange membrane \\
\hline AEM-DGFC & Anion-exchange membrane - direct glycerol fuel cell \\
\hline AEMFC & Anion-exchange membrane fuel cell \\
\hline $\mathrm{CA}$ & Chronoamperometry \\
\hline CNT & Carbon nanotube \\
\hline $\mathrm{CV}$ & Cyclic voltammetry \\
\hline DAFC & Direct alcohol fuel cell \\
\hline DEFC & Direct ethanol fuel cells \\
\hline ECSA & Electro-chemical surface area \\
\hline EDS & Energy dispersive spectroscopy \\
\hline $\mathrm{FC}$ & Fuel cell \\
\hline FTIR & Fourier transform infrared \\
\hline GC & Graphite carbon \\
\hline GCE & Glassy carbon working electrode \\
\hline HAADF-S/TEM & $\begin{array}{l}\text { High angle annular dark field scanning transmission electron } \\
\text { microscopy }\end{array}$ \\
\hline HPLC & High-performance liquid chromatograph \\
\hline HR-TEM & High-resolution transmission electron microscopy \\
\hline ICP-AES & Inductive coupled plasma atomic emission spectroscopy \\
\hline LSV & Linear scan voltammetry \\
\hline MA & Mass activity \\
\hline MEA & Membrane electrodes assembly \\
\hline MWCNT & Multi-wall carbon nanotube \\
\hline MPG & Miles per gallon \\
\hline NW & Nanowire \\
\hline OAc & Oleic acid \\
\hline OAm & Oleylamine \\
\hline ORR & Oxygen reduction reaction \\
\hline PEM-DGFC & Proton-exchange membrane - direct glycerol fuel cell \\
\hline PEMFC & Proton-exchange membrane fuel cell \\
\hline
\end{tabular}


PGA

PGM

RID

SA

SHE

SLV

TEM

TGA

TPQPOH

UPD

VWD

XPS

$\mathrm{XRD}$
Polyglycolic acid

Platinum group metal

Refractive index detector

Specific activity

Standard hydrogen electrode

Staircase linear scan voltammetry

Transmission electron microscopy

Thermal gravimetric analysis

Tris(2,4,6-trimethoxyphenyl) polysulfone-methylene quaternary

phosphonium hydroxide

Under potential deposition

Variable wavelength detector

X-ray photoelectron spectroscopy

$\mathrm{X}$-ray diffraction 


\section{Abstract}

Direct bioalcohol fuel cells and green electro-chemical production processes are two key researches that can contribute to humanity's sustainable development. To achieve efficient electro-chemical conversion, highly active nanostructured electro-catalysts are an essential requirement. However, it remains a challenging task to construct nanostructured metallic materials serving as efficient electro-catalysts for electricity generation and biorenewable alcohol conversion, because of the technical difficulty in precisely controlling their size, shape, and composition.

In my $\mathrm{Ph} . \mathrm{D}$ research, a wet chemistry-based organic solution phase reduction method was developed, and was successfully applied in the preparation of a series of advanced electro-catalysts, including 0-dimensional (0-D) Pt, Pd, Au, and Pd-Ni nanoparticles (NPs), 1-D Pt-Fe nanowires (NWs) and 2-D Pd-Fe nanoleaves (NLs), with controlled size, shape, and morphology. These nanostructured catalysts have demonstrated unique electro-catalytic functions towards electricity production and biorenewable alcohol conversion.

The molecular oxygen reduction reaction (ORR) is a long-standing scientific issue for fuel cells due to its sluggish kinetics and the poor catalyst durability. The activity and durability of an electro-catalyst is strongly related with its composition and structure. Based on this point, Pt-Fe NWs with a diameter of $2-3 \mathrm{~nm}$ were accurately prepared. They have demonstrated a high durability in sulfuric acid due to its 1-D structure, as well as a high ORR activity attributed to its tuned electronic structure. By substituting Pt with Pd using a similar synthesis route, Pd-Fe NLs were prepared and demonstrated a higher ORR activity than Pt and Pd NPs catalysts in the alkaline electrolyte.

Recently, biomass-derived alcohols have attracted enormous attention as promising fuels (to replace $\mathrm{H}_{2}$ ) for low-temperature fuel cells. From this point of view, Pd-Ni NPs were prepared and demonstrated a high electro-catalytic activity towards ethanol oxidation. 
Comparing to ethanol, the biodiesel waste glycerol is more promising due to its low price and high reactivity. Glycerol (and crude glycerol) was successfully applied as the fuel in an Au-anode anion-exchange membrane fuel cell (AEMFC). By replacing Au with a more active Pt catalyst, simultaneous generation of both high power-density electricity and value-added chemicals (glycerate, tartronate, and mesoxalate) from glycerol was achieved in an AEMFC.

To investigate the production of valuable chemicals from glycerol electro-oxidation, two anion-exchange membrane electro-catalytic reactors were designed. The research shows that the electro-oxidation product distribution is strongly dependent on the anode applied potential. Reaction pathways for the electro-oxidation of glycerol on $\mathrm{Au} / \mathrm{C}$ catalyst have been elucidated: continuous oxidation of $\mathrm{OH}$ groups (to produce tartronate and mesoxalate) is predominant at lower potentials, while $\mathrm{C}-\mathrm{C}$ cleavage (to produce glycolate) is the dominant reaction path at higher potentials. 


\section{Chapter 1 Introduction}

\subsection{Energy: A grand challenge in $21^{\text {st }}$ century}

Sustainably meeting humanity's energy needs has been identified as a top challenge for the next fifty years. ${ }^{1}$ The ease and comfort of modern life are heavily reliant on nonrenewable fossil fuels (i.e. petroleum, coal, and natural gas). As shown in the U.S. energy flow in 2010 (Fig. 1.1), fossil fuels supplied $83 \%$ of the total energy consumption (petroleum: $37 \%$; coal: $21 \%$; and natural gas: $25 \%$ ), and supported all the sectors (transportation, industrial, commercial, and residential). However, the overall energy efficiency is only $43 \%$ (41.88/98). The fossil fuels reserves are not infinite. For example, based on the data from CIA World Factbook, ${ }^{2}$ the current proved world reserves of the most important fuel, crude oil, are 1,473,878,490,000 barrels. At the present world oil consumption rate $\left(99,091,752\right.$ barrels day $\left.{ }^{-1}\right)$, the glory of these 'Modern Times' will be gone in 40 years! Even though we can use coal and natural gas to cover the gap left behind oil, it is still only a matter of time to exhaust all the fossil resources. Driven by the depletion of traditional fossil resources, developing green energy conversion approaches that use renewable and sustainable energy sources have been of unique significance. ${ }^{3}$

\subsection{Fuel cells: A clean electrical energy technology}

Fuel cells have been widely considered as a promising alternative power generation technique, due to their high energy conversion efficiency and zero pollutant emissions. As a chemical - electrical energy conversion device, a fuel cell can directly convert the Gibbs free energy of a reaction into electrical energy without the Carnot cycle's limitation. Therefore, ideally, the efficiency of a $\mathrm{H}_{2} / \mathrm{O}_{2}$-fed fuel cell, which is calculated by the ratio between the Gibbs free energy and the enthalpy change, can reach $83 \%$. A typical proton-exchange membrane fuel cell (PEMFC) stack can stably work at low temperatures (usually $<100^{\circ} \mathrm{C}$ ) while maintaining a power generation capability up to 
$250 \mathrm{~kW} .{ }^{4}$ Therefore, it is considered a promising device for portable energy suppliers, small passenger vehicles, and even small plants. However, the widespread application of fuel cells has to address two issues: The first is the sluggish kinetics of oxygen reduction reaction (at the cathode) and the unsatisfied durability of the cathode catalyst. The second is the replacement of $\mathrm{H}_{2}$ with renewable, easily stored and transported liquid fuels.

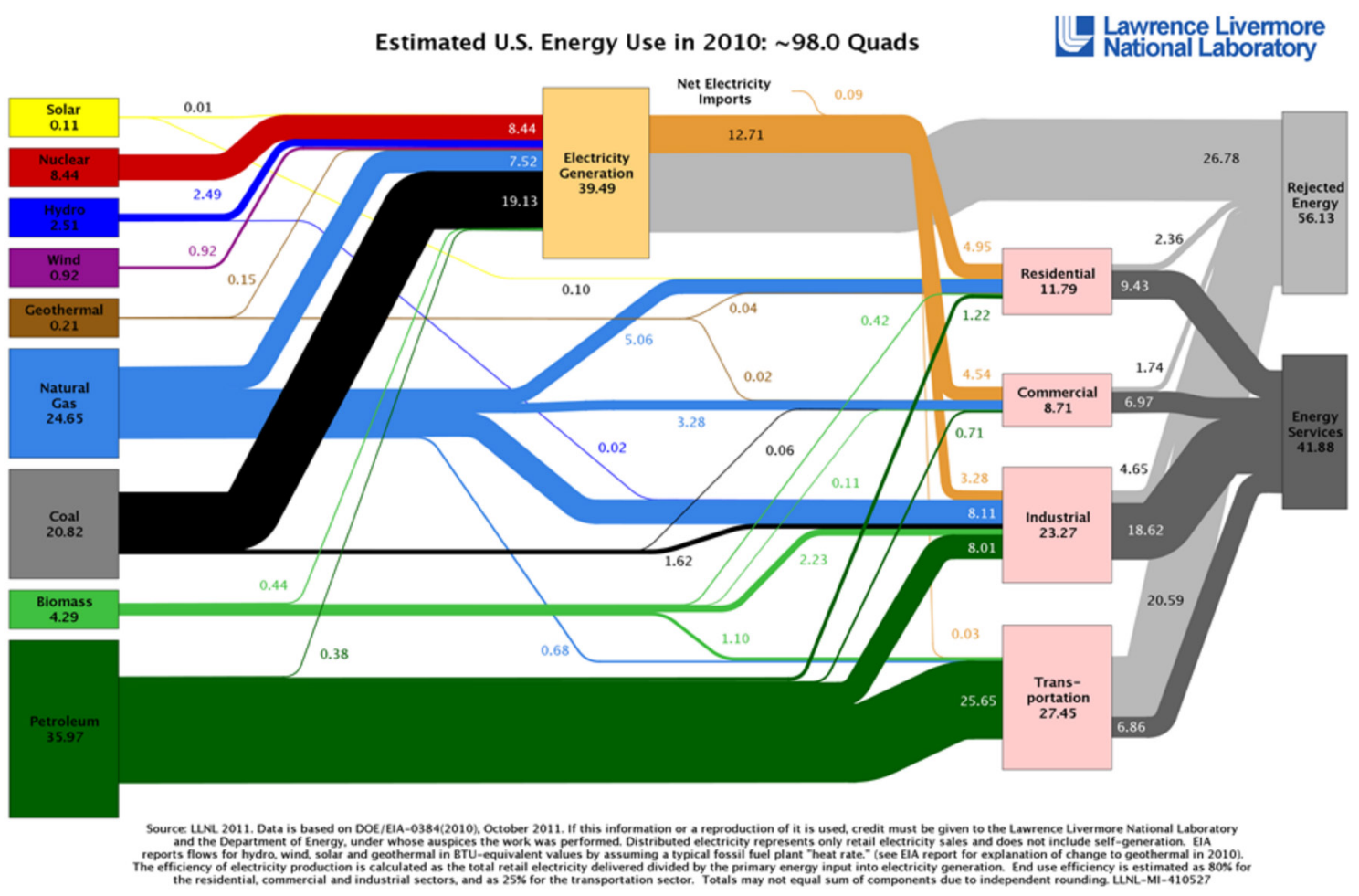

Fig. 1.1 U.S. energy flow (2010), unit is given in quad, which is $10^{15}$ BTU or $1,055 \times 10^{18}$ $\mathrm{J}^{5}$.

\subsection{Bioalcohols (ethanol and glycerol): Promising liquid fules for fuel cells}

Biomass resources are annually renewable, cheap, and abundant. Therefore, they are expected to take a big portion in our future energy landscape. The development of renewable biomass-derived fuels (such as bioethanol and biodiesel) is an important research topic for the sustainability. Spurred by the political and social concerns 
associated with the sustainable human development, in 2011, the biomass-derived ethanol has increased to 13.4 billion gallons per year in the United States. Its production will be further pushed by the U.S. Energy Independence and Security Act (passed by Congress in 2007 ) to 38 billion gallons by 2022. Alternative vehicle fuel E85 (containing $85 \%$ of denatured ethanol) is also commercially supplied at gas stations, mainly in the Midwest area. However, the efficiencies of all internal combustion engines are confined by Carnot's theorem. The efficiency of current transportation sector (mainly is internal combustion engine based) is only 25\% (as shown in Fig. 1.1, 6.85/27.45). In addition, the volumetric energy density of ethanol $\left(6.3 \mathrm{~kW} \mathrm{~h} \mathrm{~L}^{-1}\right)$ is only $65 \%$ of that of gasoline $(9.7$

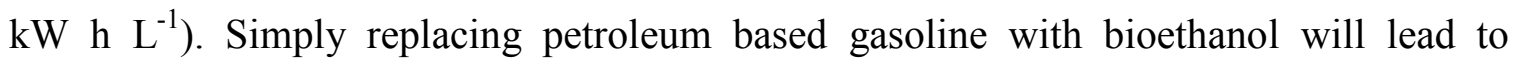
unavoidable fuel efficiency drop (lower miles per gallon, MPG).

In the meantime, production of biodiesel has been greatly stimulated by political decisions. In 2011, biodiesel production in the United State rose to 1.1 billion gallons per year. The biodiesel production is based on a chemical process of transesterification of vegetable oils, or of animal or waste fats, and the process inevitably yields $\sim 10 \mathrm{wt} \%$ of byproduct glycerol. As a result, the blooming biodiesel industry quickly leads to the saturation of the glycerol market. The price of crude glycerol subsequently drops to the

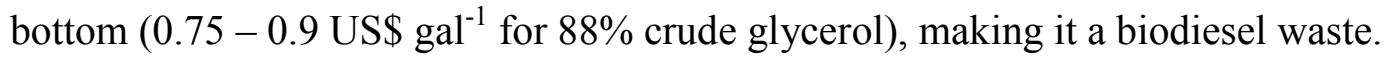

Exploration of more efficient approach to utilization of these bioalcohols is in high demand. The large amounts of low-cost bioethanol and biodiesel waste glycerol can serve as promising fuels in direct alcohol fuel cells (DAFCs). In principle, the energy conversion efficiency is not confined by the Carnot cycle limitation through direct electro-oxidation of alcohols to produce electricity. The thermodynamic (maximum) efficiency of a bioalcohol-fed fuel cell (based on the full utilized of the fuel) is higher than that of a $\mathrm{H}_{2}$-fed one (97\% for ethanol-fed and $98 \%$ for glycerol-fed fuel cells; $v s .83 \%$ for $\mathrm{H}_{2}$-fed fuel cell). In addition, the volumetric energy densities of ethanol and glycerol are also higher than that of $\mathrm{H}_{2}\left(6.3 \mathrm{~kW} \mathrm{~h} \mathrm{~L}^{-1}\right.$ for ethanol and glycerol vs. $2.6 \mathrm{~kW} \mathrm{~h} \mathrm{~L}^{-1}$ for $\mathrm{H}_{2}$ ). From these aspects, DAFC fed with biomass derived alcohols will be a promising high-efficient, cost-effective power generation technology. 


\subsection{Chemical production: Urgent need to develop green and sustainable electro-catalytic routes from biomass resources}

Development of green and sustainable routes to the production of chemicals from biomass resources is also in urgent need in order to lower the heavy dependence on the vanishing world petroleum reserves. ${ }^{7-11}$ Recently, biomass derived glycerol is obtained at very low prices. With a highly active triol structure, it has a potential serving as a main building block for a series of valuable chemicals. ${ }^{12-16}$ Great progresses have been made in heterogeneous catalysis in selective oxidation to glycerol with molecular $\mathrm{O}_{2}$ to glyceric acid $^{17,18}$ and dihydroxyacetone,,$^{19,20}$ and with $\mathrm{H}_{2} \mathrm{O}_{2}$ to glycolic acid. ${ }^{21}$ As the thermodynamics and kinetics of a reaction can be greatly enhanced under an applied potential, the electro-catalytic conversion of glycerol will be of exclusive significance, which may serve as a more efficient, eco-benign, and renewable process for chemical productions.

\subsection{Nanostructured electro-catalysts: Great opportunities to improve fuel cell performance}

Efficient electro-catalytic reactions are essential for a fuel cell. In the electro-catalytic reaction, the surface of the electro-catalyst plays a crucial role, as it is the place where all the chemistry steps are taking place, and determines the adsorption, dissociation, electron and atom transportation, and chemical bond cleavage and formation. All of these steps are directly related with the efficiency and power generation ability of the fuel cell. In early years, the investigation of electro-catalytic reaction was mainly focused on model surfaces, usually atomically clean single crystals. ${ }^{22-30}$ However, due to the low specific surface area of single crystals, large gap between ultra-vacuum and ambient pressure, and huge differences between single crystals and real-world polycrystals, these studies are mostly theoretical with little practical meanings to the application of fuel cells. 
Recently, the emergence of nanosciences and nanotechnologies, especially the precise morphology-controlled nano-material preparations, brought the electro-catalysis into a new world at the "bottom" of substances. The specific surface area greatly increases as the catalyst size shrinks into the nanoscale. For example, for a round shaped catalyst, the specific surface area will increase 100 times when its diameter reduces from $1 \mu \mathrm{m}$ to 10 $\mathrm{nm}$. Taking into account of the high prices of precious metals $\left(1,588 \mathrm{USS} \mathrm{oz}^{-1}\right.$ for $\mathrm{Au}$,

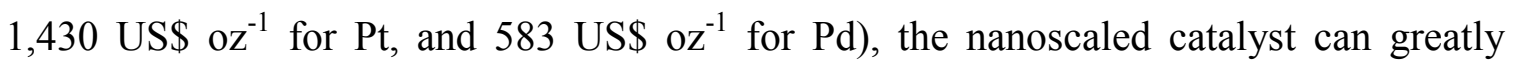
reduce the cost of precious metal catalysts.

Nano-catalysts are more attractive due to their unique electronic and physical properties, which are totally different from the bulk-scaled materials. Electro-catalysis is a catalytic process combining with the charge (electrons) transfer through the catalyst surface. In this process, the dangling bonds on catalyst surface are more active and are of unique importance in the activation of the electro-chemical reactions. When the size of catalysts shrinks to be nanoscale, the abundance of surface defects and large surface curvature will result in an increased number of dangling bonds on the surface, leading to a higher catalytic activity.

The shape-controlled nanostructures can further benefit the electro-catalytic activities. Model surface investigations based on single crystals have demonstrated that the electrocatalytic process is usually structure sensitive, which is the so-called geometrical effect. The geometrical effect is especially obvious when there is strong adsorption of species. One good example of the geometrical effect is the oxygen reduction reaction. Although the same activation energy in both acid $\left(\sim 42 \mathrm{~kJ} \mathrm{~mol}^{-1}\right)$ and alkaline $\left(\sim 40 \mathrm{~kJ} \mathrm{~mol}^{-1}\right)$ solution has been found on all three low index Pt facets, the order of ORR activity at Pt low index facets in $\mathrm{H}_{2} \mathrm{SO}_{4}$ electrolytes decreases in the sequence of (110)> (100) > (111), which is inverse to the (bi)sulfate anion adsorption sequence on these three facets. ${ }^{22}$ Therefore, the electro-catalytic activities can be further optimized by precisely controlling the nanostructure with more active facets, 
In order to further improve catalytic functions, the nanostructured catalyst can be further manipulated by employing a second or even a third element. In nanoscales, the local electronic structure can be modified by the addition of some foreign elements, which affects the adsorption-desorption energy of certain species on the active sites. Based on this so-called electronic effect theory, different bimetallic and trimetallic catalysts have been prepared and found broad applications in ORR, ${ }^{29,31-35}$ alcohols, ${ }^{36-38}$ or organic acids oxidation, ${ }^{39-44}$ etc.

\subsection{Advanced wet-chemistry synthesis methods: Essential to accurate control over metallic nano-catalysts}

It is an essential task to develop advanced synthesis methods to accurately prepare metallic nanocatalysts. The synthesis of metal nanostructures can be generally classified into 'top-down' physical (from large to smaller micro-/nano- dimensions) and 'bottom-up' chemical (from molecular/atomic scale to nano-scale) approaches. ${ }^{45}$ Generally speaking, the physical approach usually produces nanomaterials from bulk materials with the help of exact and sophisticated high price, energy-consuming equipment. On the contrary, chemical approach prepares nanostructures through a simple and economical chemical route. Typically, chemical approach could be classified into four types: self-assembly approach; hard or soft template approach; physical chemistry approach; and solutionbased wet chemistry approach. Self-assembly ${ }^{46,47}$ is a facile route to produce fancy structures. However, it is only suitable for a limited set of materials. The Template method $^{48,49}$ can have a good control over both the shape and size, but involvement of prefabricated template and the template removal greatly increased the complexity. The physical chemistry approach involves the use of sophisticated electrochemistry, ${ }^{22,50}$ photochemistry, ${ }^{51,52}$ sonochemistry, ${ }^{53}$ radiolysis, ${ }^{54}$ thermolysis ${ }^{55}$ etc. It is an effective route and usually could have a good control over both the size and shape of nanostructures; however, the special requirement of equipment will increase the cost. 
Wet chemistry method is related to reducing dissoluble metal precursors in an aqueous or an organic phase under mild conditions in the presence of surfactants. Since the shape of a crystal is determined by the relative specific surface energies with the facet of this crystal, ${ }^{56}$ wet chemistry method could easily control the nanostructures by using different surfactants to adjust the free energy of different crystallographic surfaces. Therefore, comparing to the other three methods, wet chemistry method is more economical, repeatable, and easy to carry out. Therefore, it is more suitable for both lab-scale researches and industry-scale processes. In the past years, many seminal works based on wet chemistry approach have been carried out to synthesize Ag, Au, Pt, Pd and their alloy nanostructure, such as nanowire, ${ }^{57,58}$ nanorod, ${ }^{59}$ nanocube, ${ }^{60,61}$ nanotadpole, ${ }^{62}$ and nanodendrites, ${ }^{63,64}$ etc. These nanostructures have been demonstrated as high performance electro-catalysts, and have a broad application as heterogeneous catalysts. The wet chemistry method has been reviewed in some literatures. ${ }^{65-69}$

In this thesis, a wet chemistry-based organic solution phase reduction method was developed to prepare the advanced nanostructured metal catalysts. Comparing to the aqueous phase syntheses, this method is better in controlling the size, structure, and composition of catalysts. In addition, this method is simple, reproducible and easy to scale up, at a larger production (grams of catalyst per batch).

\subsection{Goal and significance of my $P h . D$ research}

My $\mathrm{Ph} . \mathrm{D}$ research is devoted to the investigation and application of advanced metallic nanostructures for efficient durable ORR catalysts (at the cathode) for fuel cells (Chapter 3 and 4), and highly active alcohol oxidation catalysts (at the anode, Chapter 5, 6, and 7). In addition, an electro-catalytic process was also explored based on the nano-catalysts, which is more efficient than traditional heterogeneous catalysis in selective oxidation of low cost, green technology processed alcohols into valuable oxygenated chemicals (Chapter 8). 
My Ph.D research has successfully developed a series of advanced nanostructured metal electro-catalysts for efficient electricity generation and selective the conversion of biorenewable glycerol into high value chemicals. This will help to find solutions to partially alleviate our energy dependence on the declining fossil resources. My research also explored a new electro-catalytic process for valuable chemical production from biorenewable compounds. This may become a promising green route in reducing the chemical production dependence on traditional fossil resources. 


\section{Chapter 2 General Experimental}

\subsection{Organic solution phase synthesis method}

\subsubsection{Chemicals}

$\mathrm{Pt}(\mathrm{acac})_{2}, \quad \mathrm{Pd}(\mathrm{acac})_{2}, \quad \mathrm{PdCl}_{2}, \mathrm{Fe}(\mathrm{CO})_{5}, \mathrm{Ni}(\mathrm{acac})_{2} \cdot 2 \mathrm{H}_{2} \mathrm{O}, \operatorname{LiBEt}_{3} \mathrm{H}$ (1 $\mathrm{M}$ in $\left.\mathrm{THF}\right)$, octadecene, and benzyl ether are purchased from Acros Organics. Oleylamine and telfon are purchased from Aldrich Chemistry. Oleic acid and $\mathrm{NiCl}_{2} \cdot 2 \mathrm{H}_{2} \mathrm{O}$ are purchased from Fisher Chemical. $\mathrm{NaBH}_{4}$ and $\mathrm{AuCl}_{3}$ are purchased from Alfa Aesar. Acetone and Ethylene glycol (EG) are purchased from BDH. Hexane is purchased from Mallinckrodt Chemicals. Ethanol is purchased from Pharmco-Aaper. Carbon black (Vulcan XC-72R) is purchased from Fuel Cell Store.

\subsubsection{Synthesis system and typical catalyst preparation procedures}

A typical setup for organic solution phase synthesis of advanced nanostructured electrocatalysts is shown in Fig. 2.1. The reaction precursors, solvent, and surfactants were first introduced into a $250 \mathrm{ml}$ standard four-neck round bottom flask (Chemglass). The reaction was allowed by heating the system to a certain temperature through a hemispherical mantle heater (Glas-Col) under inert $\mathrm{N}_{2}$ protection. The temperature was controlled by temperature controller (J-KEM APOLLO) coupled with a Teflon coated thermocouple. During the reaction, the solution was stirred by a Teflon coated magnetic stirring bar (Fisherbrand), which is driven by a magnetic stirrer (ATE).

For the preparations of $\mathrm{Pd}-\mathrm{Ni} / \mathrm{C}$ (Chapter 5) and $\mathrm{Pt} / \mathrm{C}$ (Chapter 7), carbon supports (Vulcan XC-72R) was first dispersed into the solvent under sonication to directly prepare the corresponding carbon supported catalysts. The as-prepared catalysts were then collected by filtration, washed with copious of ethanol, and dried in a vacuum oven (Baxter Vacuum Drying Oven DP-32) overnight at $50^{\circ} \mathrm{C}$. 


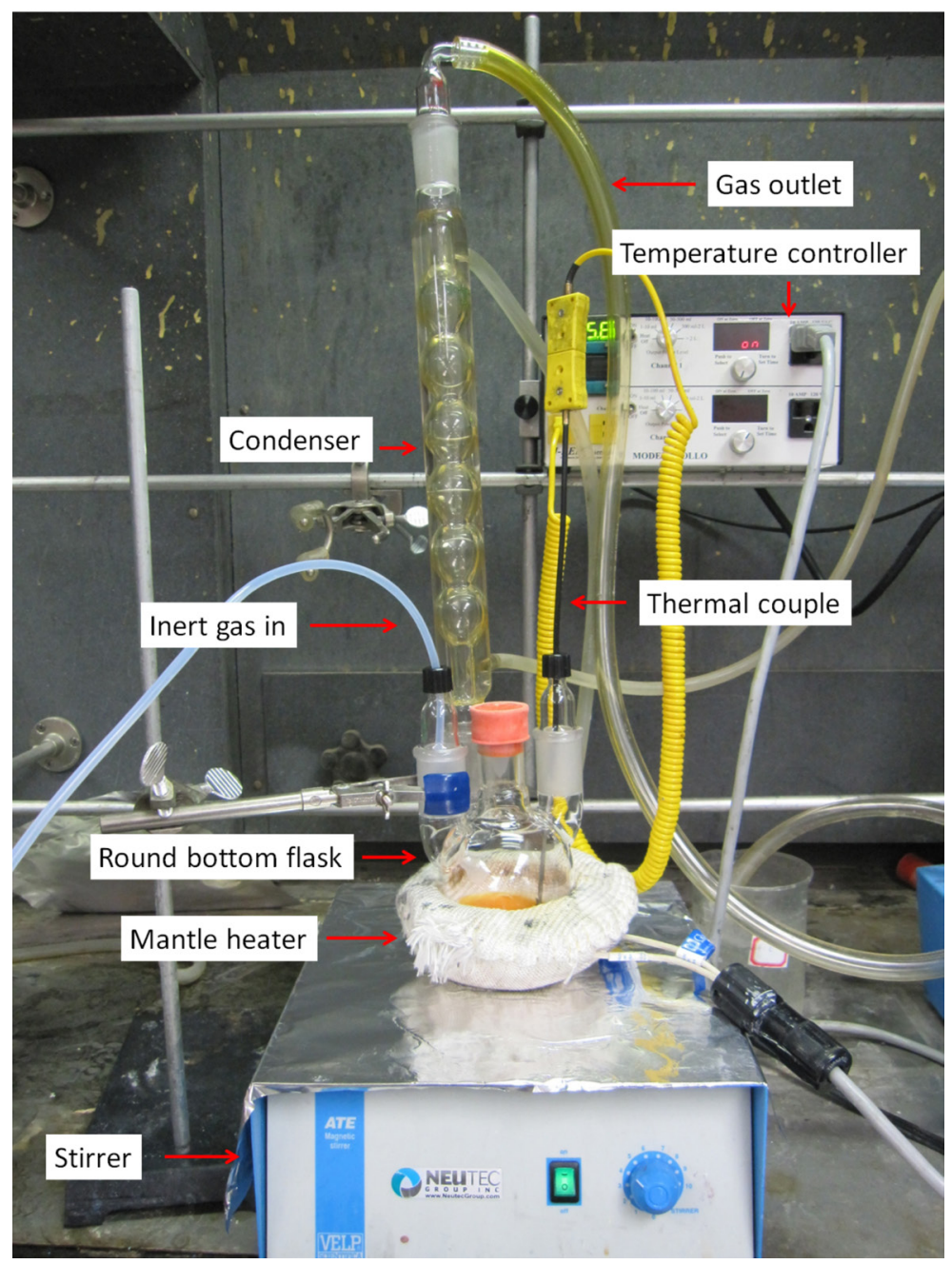

Fig. 2.1 Experimental setup for the organic solution phase synthesis of nanocatalysts.

For Pt-Fe NWs (Chapter 3), Pd-Fe NLs (Chapter 4), Au/C (Chapter 6 and 8), and $\mathrm{Au} / \mathrm{CNT}$ (Chapter 8), the non-supported nanostructure was first separated from the synthesis system, and then deposited on the carbon supports. The procedure is as follows: A certain amount of polar solution (ethanol or isopropanol) was first added into the organic phase synthesis system. The as-prepared nanostructure was then separated by centrifugation (6000 - 10000 revolutions per minute (rpm), Thermo Scientific Legend $\mathrm{X} 1$ ). The product was cleaned by re-dispersing into a mixture of hexane and polar solution and separating by centrifugation multiple times and stored in hexanes. To prepare carbon supported catalysts, an appropriate amount of carbon support (carbon black or carbon nanotube (CNT)) was first dispersed into ethanol or isopropanol under 
sonication to achieve a uniform ink. The hexane dispersed nanostructure was then added dropwisely into the ink under vigorous stirring. The final carbon supported electrocatalyst was obtained after filtration and dried in a vacuum oven overnight at $50^{\circ} \mathrm{C}$.

\subsection{Material Characterizations}

\subsubsection{Transmission electron microscopy (TEM)}

TEM images of as-prepared catalysts were usually collected on JEOL 2010 with an operating voltage of $200 \mathrm{KV}$, unless otherwise mentioned. Before tests, the as-prepared catalysts were first dispersed in ethanol or isopropanol to form a uniform dilute solution, followed by depositing one or two drops of this solution on a carbon film covered copper grid (Ted Pella, Inc). The average size (length or diameter) and the histogram of the asprepared samples were analyzed from the TEM images, by randomly measuring over 100 nanostructures.

\subsubsection{High-Resolution TEM (HR-TEM)}

HR-TEM images of Pd-Fe NLs (Chapter 4) and Pd-Ni (Chapter 5) were collected by our collaborators in University of Michigan, on JEOL 2040 with an operating voltage of $300 \mathrm{KV}$. The surface crystal facet was investigated in HR-TEM by measuring the atom interlayer spacing.

\subsubsection{High angle annular dark field (HAADF) scanning transmission electron microscopy (S/TEM)}

Simultaneous HAADF-STEM, TEM, and SEM imaging of Pd-Fe NLs (Chapter 4) was performed by our collaborator in Oak Ridge National Lab, using a Hitachi HF3300 TEM/STEM operated at $300 \mathrm{kV}$. HAADF-S/TEM was conducted using a probe-corrected 
(CEOS aberration-corrector) JEOL 2200FS with an operating voltage of $200 \mathrm{kV}$. Highspatial-resolution EDS compositional analysis (Bruker X-flash silicon drift detector (SDD)) was performed on this microscope using a beam diameter of $\sim 2 \AA$ and beam current of $\sim 1400 \mathrm{pA}$.

\subsubsection{X-ray photoelectron spectroscopy (XPS)}

XPS spectra of Pd-Fe NLs (Chapter 4) were collected by our collaborator in Oak Ridge National Lab, using a Thermo Scientific K-Alpha instrument. Samples for XPS were prepared by depositing a thin layer of the catalyst on a silicon substrate.

\subsubsection{X-ray diffraction (XRD)}

A Scintag XDS-2000 $\theta / \theta$ Diffractometer with $\mathrm{Cu} \mathrm{K}_{\alpha}$ radiation $(\lambda=1.5406 \AA)$, with a tube current of $35 \mathrm{~mA}$ and a tube voltage of $45 \mathrm{KV}$ was employed to collect X-ray diffraction data for the as-prepared nanostructures. Samples for XRD test were prepared by dispersing a thin layer of the electro-catalysts on a zero background silicon substrate. The crystal size of nanostructures will be calculated by Debye-Scherrer formula:

$$
L=\frac{0.9 \lambda_{K_{\alpha}}}{B_{2 \theta} \cos \theta_{\max }}
$$

where $\mathrm{L}$ is the mean crystal size (diameter of nanostructures), $\lambda_{K \alpha}$ is the wavelength of $\mathrm{X}$ ray $(1.5406 \AA), B_{2 \theta}$ is the full width at half-maximum of the peak (rad), and $\theta_{\max }$ is the Bragg angle (deg).

And the lattice parameter $\left(\alpha_{f c}\right)$ is calculated by the following equation:

$$
\alpha_{f c c}=\frac{\sqrt{2} \lambda_{K_{\alpha}}}{\sin \theta_{\text {max }}}
$$




\subsubsection{Inductively coupled plasma atomic emission spectroscopy (ICP-}

AES)

ICP-AES was employed to analyze the bulk elements composition of the as-prepared catalysts, as well as the metal loading of the carbon deposited catalysts. A certain amount of catalyst (1 - 5 mg) was carefully measured and dissolved in $4.0 \mathrm{ml}$ Aqua Regia (A strong oxidative acid formed by mixing concentrated nitric acid and hydrochloric acid with the volume ratio of 1:3). The solvent was then accurately diluted to $15 \mathrm{ml}$ for the composition analysis.

\subsubsection{Thermal gravimetric analysis (TGA)}

Thermal gravimetric analysis was carried out on TGA Q500 (TA Instruments) in order to analyze the weight ratio of surfactants and the metal loading of the as-prepared catalysts. $6-10 \mathrm{mg}$ of the sample was placed in an inert alumina pan and heated from the room temperature (RT) to $500^{\circ} \mathrm{C}$ under a $\mathrm{N}_{2}$ gas flow, at the heating rate of $10^{\circ} \mathrm{C} \mathrm{min}^{-1}$. The temperature was held there for $20 \mathrm{~min}$, before switching the purge gas to regular air. The temperature was then increased to $900^{\circ} \mathrm{C}$ at the same heating rate.

\subsection{Electro-chemical investigation}

\subsubsection{Electro-chemical tests in half cell}

\subsubsection{Instrument and working electrode preparation}

The half cell tests were performed in a conventional three-compartment cell (AFCELL3, Pine Instrument) with a glassy carbon working electrode (GCE) and a Pt wire counter electrode. $\mathrm{Hg} / \mathrm{HgO} / 1.0 \mathrm{M} \mathrm{KOH}$ electrode (Pine instruments) and standard hydrogen electrode (SHE, Hyderoflex ${ }^{\circledR}$ ) were applied as the reference electrodes in alkaline and acid electrolytes, respectively. All the potentials are given $v s$. the employed reference 
electrode, unless otherwise mentioned. Data was collected by a multi-channel potentiostat (Versastat MC, Princeton applied research). The whole setup is shown in Fig 2.2. Prior to preparing the working electrode, the GCE was first carefully polished with $0.5 \mu \mathrm{m}$ and $0.05 \mu \mathrm{m}$ alumina suspensions to form a mirror like surface. After that, $1.0 \mathrm{mg}$ of catalyst was dispersed in $1.0 \mathrm{ml}$ of ethanol or isopropanol under sonication, to make a uniform ink. The working electrode was prepared by depositing a certain amount of the catalyst ink on the polished GCE dropwisely, which was subsequently covered by dilute ionomer solution (Nafion ${ }^{\circledR}$, TPQPOH, or Tokuyama AS-4). The prepared working electrode was dried in vacuum oven at $70^{\circ} \mathrm{C}$ in order to remove all the solution (ethanol or isopropanol).
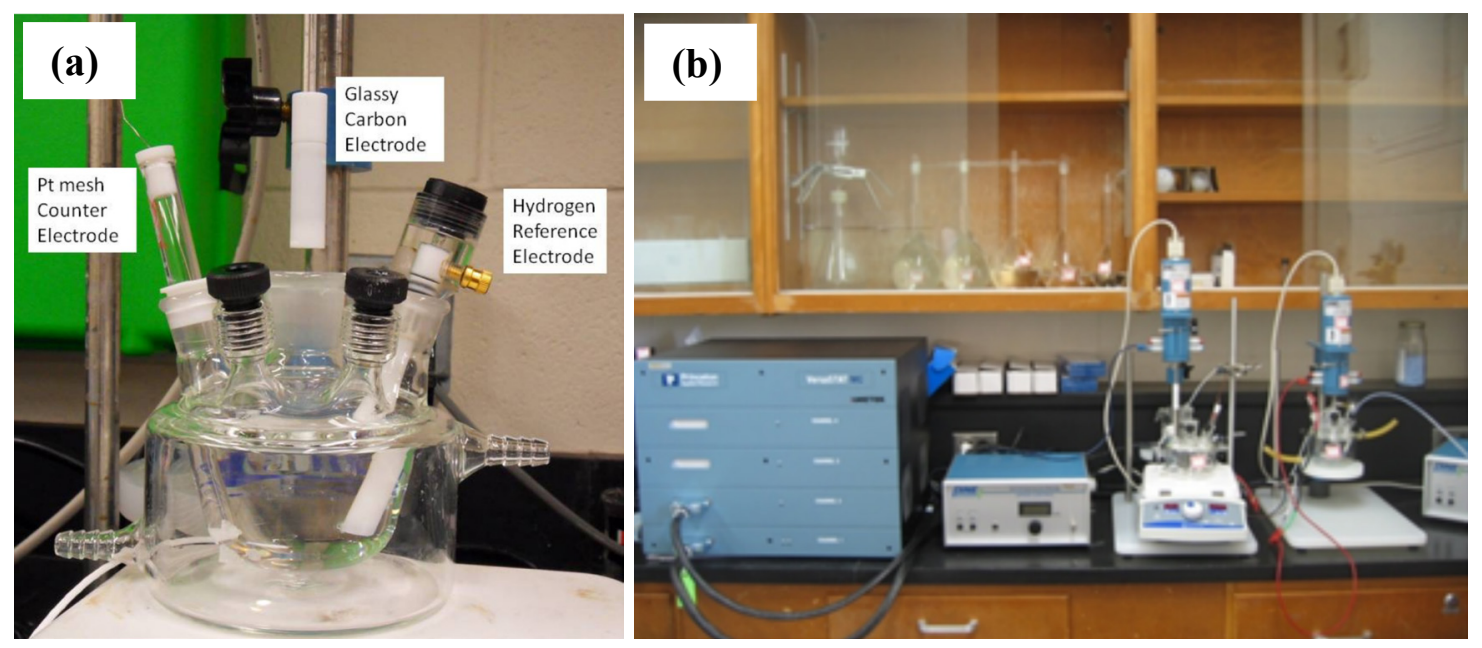

Fig. 2.2 half cell tests setups: (a) a three-compartment-cell with a reversible hydrogen reference electrode and a Pt wire counter electrode; (b) electro-chemical workstation lined with three-compartment-cell and rotating disk electrode.

\subsubsection{Cyclic voltammetry (CV) scan}

CV scans were carried out in either $0.5 \mathrm{M} \mathrm{H}_{2} \mathrm{SO}_{4}$ or in $1.0 \mathrm{M} \mathrm{NaOH}$ (or $1.0 \mathrm{M} \mathrm{KOH}$ ) to obtain the electro-chemical surface areas (ECSAs) of the as-prepared electro-catalysts. The sweep rate (v) was set at $50 \mathrm{mV} \mathrm{s}^{-1}$, and the ECSA was calculated from the following equation:

$$
S_{e}=\frac{Q_{r}}{m \times C}
$$


where $\mathrm{m}$ is the mass of precious metal on the GCE, $\mathrm{Q}_{\mathrm{r}}$ is the transferred charge for a specific electro-chemical reaction, and $\mathrm{C}$ is the corresponding charge density for the reaction. $\mathrm{Q}_{\mathrm{r}}$ is calculated by the equation:

$$
Q_{r}=\frac{1}{v} \int_{a}^{b}\left(I-I_{d l}\right) d E
$$

where $v$ is the sweep rate, $a$ and $b$ are the starting and stopping potentials for the reaction, and $I_{d l}$ is the current generated from double layer charging, which is assumed as a constant.

Typically, the $\mathrm{H}_{2}$ under-potential desorption reaction was chosen in acid electrolyte, whereas the reduction of metal oxide was chosen in alkaline electrolyte, to evaluate the ECSA of the electro-catalyst.

CV scans were also performed in alcohol alkaline electrolyte in order to study the catalytic activity of the as-prepared catalyst towards alcohol oxidation. The sweep rate was fixed at $50 \mathrm{mV} \mathrm{s}^{-1}$, while the ratio of alcohol to alkaline concentration was varied to investigate their effects.

\subsubsection{Linear scan voltammetry (LSV)}

A LSV was performed in either $\mathrm{O}_{2}$ saturated $0.5 \mathrm{M} \mathrm{H}_{2} \mathrm{SO}_{4}$ (Chapter 3) or $0.1 \mathrm{M} \mathrm{NaOH}$ (Chapter 4) to investigate the catalytic activity of the as-prepared catalyst towards the oxygen reduction reaction (ORR). The sweep rate was set at $10 \mathrm{mV} \mathrm{s}^{-1}$, while the rotation rate was controlled at $2500 \mathrm{rpm}$. The ORR activity can be presented by the kinetic current density $\left(i_{k}\right)$, which represents the current without any mass transfer effects. The kinetic current density is calculated by the Levich-Koutecky equation: ${ }^{70}$

$$
\frac{1}{i}=\frac{1}{i_{k}}+\frac{1}{i_{f}}+\frac{1}{i_{d}}=\frac{1}{i_{k}}+\frac{L}{n F C_{f} D_{f}}+\frac{1}{B C_{O} \omega^{\frac{1}{2}}}=\frac{1}{i_{k}}+\frac{L}{n F C_{f} D_{f}}+\frac{1}{0.62 n F D_{O}^{\frac{2}{3}} \nu^{-\frac{1}{6}} C_{O} \omega^{\frac{1}{2}}}
$$

where $\mathrm{i}$ is the current density collected from the working electrode, $\mathrm{i}_{\mathrm{k}}$ is the kinetic current density, $i_{\mathrm{f}}$ is the diffusion limiting current density in the polymer electrolyte (Nafion, TPQPOH, or AS-4) film covering the catalyst layer, $i_{d}$ is the diffusion limiting 
current density through the solution boundary layer; $\mathrm{C}_{\mathrm{f}}$ is the $\mathrm{O}_{2}$ concentration at the outer boundary of film, $\mathrm{D}_{\mathrm{f}}$ is diffusion coefficient of $\mathrm{O}_{2}$ in the film, $\mathrm{L}$ is the film thickness; $\mathrm{D}_{\mathrm{O}}$ is the diffusion coefficient of $\mathrm{O}_{2}$ in the bulk electrolyte, $v$ is the kinematic viscosity of the electrolyte, $\mathrm{C}_{\mathrm{O}}$ is the $\mathrm{O}_{2}$ concentration in the bulk electrolyte. In $0.5 \mathrm{M}$ $\mathrm{H}_{2} \mathrm{SO}_{4}, \mathrm{C}_{\mathrm{O}}$ is $1.26 \times 10^{-3} \mathrm{~mol} \mathrm{~L}^{-1}$; $\mathrm{D}_{\mathrm{O}}$ is $1.93 \times 10^{-5} \mathrm{~cm}^{2} \mathrm{~s}^{-1}$; $v$ is $1.009 \times 10^{-2} \mathrm{~cm}^{2} \mathrm{~s}^{-1} .{ }^{23} \mathrm{In} 0.1$ $\mathrm{M} \mathrm{NaOH}, \mathrm{C}_{\mathrm{O}}$ is $1.13 \times 10^{-6} \mathrm{~mol} \mathrm{~L}^{-1}$; $\mathrm{D}_{\mathrm{O}}$ is $2.22 \times 10^{-5} \mathrm{~cm}^{2} \mathrm{~s}^{-1} ; v$ is $1.1 \times 10^{-2} \mathrm{~cm}^{2} \mathrm{~s}^{-1}{ }^{71}$

The polymer electrolyte film is usually thinner than $0.1 \mu \mathrm{m}$ in the half cell test. Therefore, the second part $\left(\frac{1}{i_{f}}\right)$ on the right side can be neglected. Therefore, the Levich-Koutecky equation is simplified to:

$$
\frac{1}{i}=\frac{1}{i_{k}}+\frac{1}{i_{d}}
$$

Solving for $i_{k}$, the equation is arranged as following:

$$
i_{k}=\frac{i \times i_{d}}{i_{d}-i}
$$

LSVs were also performed in alcohol alkaline electrolyte to study the alcohol oxidation activity of the as-prepared catalyst (Chapter $\mathbf{5}$ and 6). The sweep rate was chosen as 1 $\mathrm{mV} \mathrm{s}^{-1}$ in order to minimize the mass transfer and diffusion issues, and therefore, allow the alcohol oxidation to take place on the catalyst at quasi-steady state. The onset potential of alcohols oxidation is defined as the potential where the inflection is observed on the quasi-steady state polarization curve.

To study the Tafel slope and exchange current density of an alcohol oxidation, the relationship between the current density and over-potential is described as:

$$
\eta=2.303 \frac{R T}{\alpha n F} \log \left(\frac{j}{j_{0}}\right)
$$

where $\eta$ is the over-potential $\left(\eta=E-E_{\text {theory }}\right), \alpha$ is the anodic transfer coefficient, $n$ is the number of electrons transferred in the reaction, and $\mathrm{j}_{0}$ is the exchange current density. The quantity proceeding the logarithm is defined as Tafel slope $b=2.303 \frac{R T}{\alpha n F}$. The Tafel 
plots were achieved by plotting the overpotential $(\eta)$ against log $(j)$. The exchange current density $\mathrm{j}_{0}$ was obtained by extrapolating the linear fitted Tafel line to where the over potential equals zero.

\subsubsection{Staircase linear scan voltammetry (SLV)}

SLVs coupled with online sample collection offline HPLC analysis techniques were applied to investigate the instantaneous products under different potentials of glycerol oxidation in alkaline electrolytes (Chapter 7). The online products collection system is illustrated by the scheme in Fig. 2.3, which is enlightened by the publications in Koper's group. $^{72-74}$ In the course of SLVs with an increment of $100 \mathrm{mV}(10 \mathrm{~min})^{-1}$, the instantaneous reaction products under different potentials were collected on-line through a self-designed collector whose tip was positioned within $0.5 \mathrm{~mm}$ to the center of working electrode surface. Before collection, the needle was washed with copious amounts of de-ionized water. The collection rate was controlled at $50 \mu 1 \mathrm{~min}^{-1}$ by a peristaltic pump (Gilson minipuls 3). At each potential, $0.5 \mathrm{ml}$ sample was collected and stored in a $2 \mathrm{ml}$ screw cap vial (Agilent).

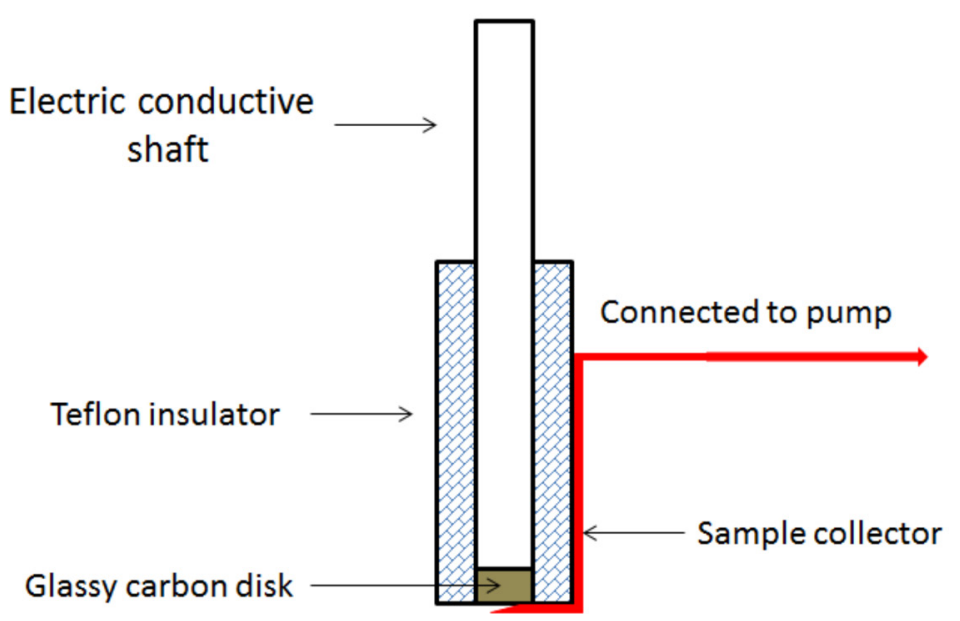

Fig. 2.3 Scheme of online product collection system. 


\subsubsection{Chronoamperometry (CA)}

CAs were employed to study the electro-oxidation of alcohols at a certain potential (Chapter 5 and 8), while the current was recorded as a function of time.

\subsubsection{Anion-exchange membrane fuel cell (AEMFC) test}

\subsubsection{Fabrication of membrane electrodes assembly (MEA)}

MEA was mechanically sandwiched with anode, solid electrolyte membrane, and cathode, without any hot-press. A catalyst ink containing $90 \mathrm{wt} \%$ of as-prepared catalyst and 10 $\mathrm{wt} \%$ of Teflon was airbrushed on a carbon cloth anode liquid diffusion layer. On the cathode, $70 \mathrm{wt} \%$ of a commercial non-Pt group metal (PGM) HYPERMECTM catalyst $\left(\mathrm{Fe}-\mathrm{Cu}-\mathrm{N}_{4} / \mathrm{C}\right.$, Acta) was blended with $30 \mathrm{wt} \%$ AS-4 anion conductive ionomer (Tokuyama), and sprayed directly onto the A201 anion-exchange membrane (Tokuyama). A 25CC carbon paper (SGL Group) was then covered on the cathode catalyst as a cathode gas diffusion layer.

\subsubsection{Electricity generation performance investigation}

The electricity performance of AEMFC was evaluated in a fuel cell stack with an active cross-sectional area of $5.0 \mathrm{~cm}^{2}$, controlled by a fuel cell test station (Scribner $850 \mathrm{e}$ ). An alcohol $\mathrm{KOH}$ solution was applied to the anode through a peristaltic pump (Gilson minipuls 3), while high purity $\mathrm{O}_{2}(99.999 \%)$ was applied to the cathode at a constant flow rate of $0.4 \mathrm{~L} \mathrm{~min}^{-1}$ under $30 \mathrm{psi}$ back pressure. The fuel cell and cathode humidification temperature was controlled from 50 to $80^{\circ} \mathrm{C}$ 


\subsubsection{Product analysis}

The liquid phase product distribution of an alcohol oxidation was investigated by continuously looping $55 \mathrm{ml}$ of alcohol $\mathrm{KOH}$ solution from a plastic vessel into the anode, while a constant cell operation voltage was applied at $50^{\circ} \mathrm{C}$. The products at different cell operation voltages were analyzed using a High-performance liquid chromatography HPLC (Agilent 1100) with a refractive index detector (RID, G1362A, Agilent) and a variable wavelength detector (VWD, $220 \mathrm{~nm}$, Agilent G1314A). The samples were separated using an OA-1000 column (Alltech) at $60^{\circ} \mathrm{C}$ with an eluent of $5 \mathrm{mM}$ aqueous sulfuric acid $\left(0.3 \mathrm{ml} \mathrm{min}^{-1}\right)$. The products were identified by comparison with authentic samples. The concentration was calculated from the peak area observed in liquid chromatograms.

For the products analysis in anion-exchange membrane - direct glycerol fuel cells (AEM-DGFC) (Chapter 6 and 7), the selectivity (S) is defined as the moles of product divided by the moles of $C_{2}$ and $C_{3}$ products observed at the given time: ${ }^{75,76}$

$$
\text { Selectivity }=\frac{\text { Moles of specific product forms }}{\text { Total moles of } C_{2} \text { and } C_{3} \text { products detected }} \times 100 \%
$$

The carbon balance is calculated by the following equation:

$$
\text { Carbon balance }=\frac{3 M_{G_{i}}-3 M_{C_{3}}-2 M_{C_{2}}-M_{C_{1}}-3 M_{G_{f}}}{3 M_{G_{i}}} \times 100 \%
$$

where $\mathrm{M}_{\mathrm{Gi}}$ and $\mathrm{M}_{\mathrm{Gf}}$ are the initial and final moles of glycerol in the electrolyte, $\mathrm{M}_{\mathrm{C} 3}, \mathrm{M}_{\mathrm{C} 2}$, and $\mathrm{M}_{\mathrm{C} 1}$ are the moles of $\mathrm{C}_{3}$ products (glycerate, tartronate, and mesoxalate), $\mathrm{C}_{2}$ products (glycolate and oxalate), and $\mathrm{C}_{1}$ products (formate and carbonate), respectively. Assuming that no $\mathrm{C}_{2}$ product was further oxidized to $\mathrm{C}_{1}$ products, $\mathrm{M}_{\mathrm{C} 2}$ is equal to $\mathrm{M}_{\mathrm{C} 1}$. Therefore, the equation can be simplified as:

$$
\text { Carbon balance }=\frac{M_{G_{i}}-M_{C_{3}}-M_{C_{2}}-M_{G_{f}}}{M_{G_{i}}} \times 100 \%
$$

where a smaller carbon balance indicates less $C_{2}$ chemicals were further oxidized to $C_{1}$ products 
Based on the product distributions, the Faradic efficiency $\left(\eta_{\mathrm{e}}\right)$, which is defined as the ratio of transferred electrons in the partial oxidation to that in the complete oxidation (combustion to $\mathrm{CO}_{2}$ ), was calculated by using the following equation:

$$
\eta_{e}=\sum S_{i} \bullet \eta_{e_{i}}
$$

where $S_{i}$ is the selectivity of product $i$, and $\eta_{e i}$ is the Faradic efficiency of partial oxidation product. 


\section{Chapter 3 Synthesis of Pt-Fe nanowires as highly durable catalysts for oxygen reduction reaction*}

\subsection{Introduction}

\subsubsection{Operation mechanism and thermodynamics of $\mathrm{H}_{2} / \mathrm{O}_{2}$-fed PEMFC}

The operation mechanism of a typical $\mathrm{H}_{2}$-fed PEMFC is illustrated in Fig. 3.1. $\mathrm{H}_{2}$ is introduced to the anode and is oxidized to generate protons and electrons. The protons go through membrane (usually Nafion membrane), while electrons go through the external circuit and react with $\mathrm{O}_{2}$ to produce water at the cathode.

At the anode, the electro-oxidation of $\mathrm{H}_{2}$ is as follows:

$$
H_{2} \longrightarrow 2 H^{+}+2 e^{-} \quad E_{a}^{0}=0.000 \mathrm{~V} \text { vs. SHE }
$$

At the cathode, the electro-reduction of $\mathrm{O}_{2}$ takes place as follows:

$$
\mathrm{O}_{2}+4 \mathrm{H}^{+}+4 e^{-} \longrightarrow 2 \mathrm{H}_{2} \mathrm{O} \quad E_{c}^{0}=1.229 \mathrm{~V} \text { vs. SHE }
$$

Therefore, the standard cell voltage is $1.229 \mathrm{~V}$. The corresponding overall fuel cell reaction is:

$$
\mathrm{H}_{2}+\frac{1}{2} \mathrm{O}_{2} \longrightarrow \mathrm{H}_{2} \mathrm{O} \quad E^{0}=1.229 \mathrm{~V}
$$

The theoretical efficiency is defined as the ratio between the electrical energy produced by fuel cell and the combustion heat at constant pressure:

$$
\varepsilon_{\text {cell }}^{\text {rev }}=\frac{\Delta G^{0}}{\Delta H^{0}}=\frac{237 \mathrm{~kJ} \mathrm{~mol}^{-1}}{286 \mathrm{~kJ} \mathrm{~mol}^{-1}} \times 100 \%=83 \%
$$

\footnotetext{
*The material contained in this chapter was previously published in Nanotechnology. Reprinted with permission from Nanotechnology 2011; 22(1), 015602 by Zhiyong Zhang, Meijun Li, Zili Wu, and Wenzhen Li. "Ultra-thin PtFe-nanowires as durable electrocatalysts for fuel cells", DOI: 10.1088/0957-4484/22/1/015602, Copyrith 2011 IOP Publishing Ltd.
} 


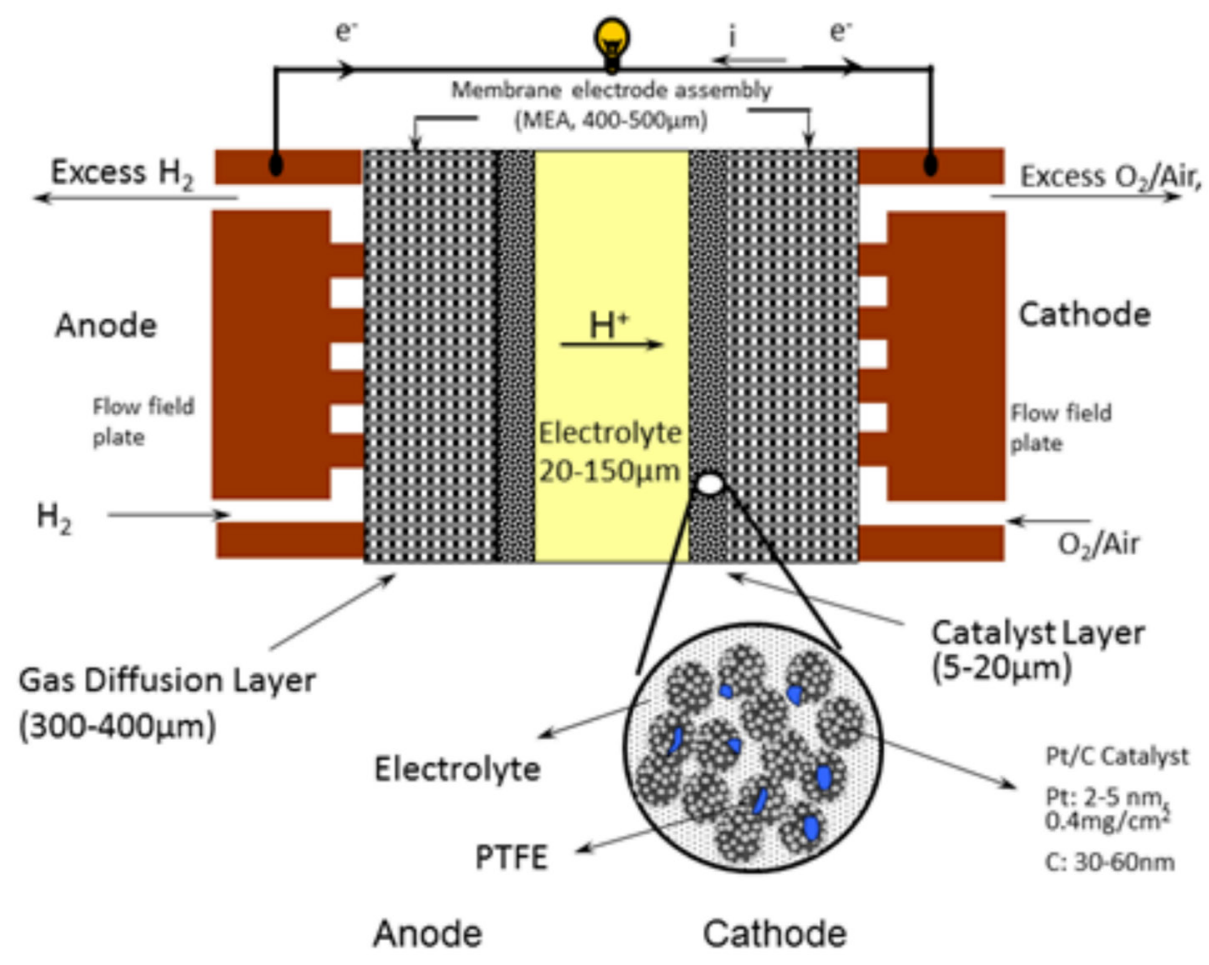

Fig. 3.1 Schematic drawing of a proton-exchange membrane fuel cell.

\subsubsection{Oxygen reduction reaction (ORR) and the challenges in the durability of cathode catalyst}

Compared to the fast, efficient anode $\mathrm{H}_{2}$ oxidation reaction, the ORR at the cathode is more complicated and always limits the fuel cell performance. Generally, an ORR in acid media can be described by a modified Wroblowa scheme, which as Fig. 3.2. ${ }^{22,29,77} \mathrm{O}_{2}$ is firstly adsorbed on the catalyst surfaces to form $\mathrm{O}_{2}$, ad, then it can either be directly electro-chemically reduced by $\mathrm{k}_{1}$ path to form $\mathrm{H}_{2} \mathrm{O}$ by a 4-e path, or go through a set of pathways through the intermediate of $\mathrm{H}_{2} \mathrm{O}_{2}$, ad by $\mathrm{k}_{2}$ path. The adsorbed $\mathrm{H}_{2} \mathrm{O}_{2}$, ad can further go through $\mathrm{k}_{3}$ path to form $\mathrm{H}_{2} \mathrm{O}\left(2+2 \mathrm{e}^{-}\right)$, or desorbed into the bulk of the electrolyte, or can even be catalytically decomposed back to $\mathrm{O}_{2}$ and water. As shown in the reaction pathway in Fig. 3.2, the ORR contains a series of elementary reaction steps, intermediates, and multiple electrons transfer. The kinetics is usually very slow due to its complexity. ${ }^{78}$ A highly active cathode catalyst is an essential requirement to allow the 
ORR kinetics practicable for fuel cell application. Although many attempts were devoted to create a non-Pt catalyst for low temperature ORR catalyst, ${ }^{79-82} \mathrm{Pt}$-based catalysts remains the most practical ones. ${ }^{29} 83$

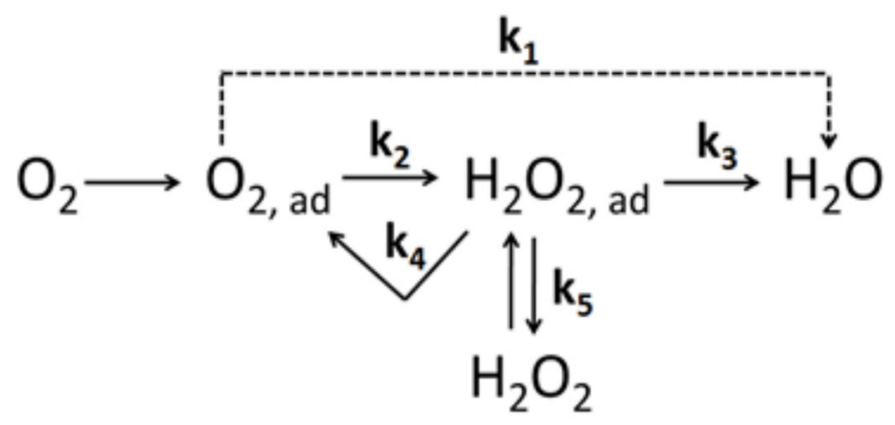

Fig. 3.2 Proposed schemes for oxygen reduction reaction in acid media ${ }^{22}$.

However, the harsh working conditions of cathode catalysts in real fuel cells, high acid environment $(18 \mathrm{M}$ ) and working potential (usually $>0.6 \mathrm{~V}$ ), always lead to gradually reduction in the cathode catalytic activity, even for the most stable Pt catalyst. ${ }^{84-86}$

For Pt nanoparticle cathode catalyst, four mechanisms have been proposed to explain its instability in low temperature fuel cells (as shown in Fig 3.3): ${ }^{86,87}$ a) Modified Ostwald ripening (especially at cathode, $>0.8 \mathrm{~V}$ ), which involves the dissolution of small $\mathrm{Pt}$ particles and its diffusion to large Pt particles driven by the reduction of surface energy. $b$ ) Pt crystal migration and coalescence (at lower voltage), which involves the motion of $\mathrm{Pt}$ particles and their coalescence on the surface of the carbon support. c) Detachment (remarkable when $>1.1 \mathrm{~V}$ ), which is related to the Pt particles dislocate from the carbon support, as the result of carbon corrosion, and agglomerate together. d) Dissolution and re-precipitation, which are due to the soluble Pt species precipitate out in the ionomer and membrane under chemical reduction.

Among these four degradation mechanisms, both the Ostwald ripening and the dissolution - re-precipitation are governed by the intrinsic properties of the metal catalyst, therefore it is important to improve the stability of the metal catalyst. From this point of 
view, different Pt-M ( $\mathrm{M}=\mathrm{Au}, \mathrm{Pd}, \mathrm{Co}, \mathrm{Ni}, \mathrm{Cu})$ bi-metallic catalysts were prepared to increase the durability of the cathode catalyst. ${ }^{32,35,88}$

Zhang et al. developed a high durability $\mathrm{Au} / \mathrm{Pt} / \mathrm{C}$ catalyst through an under potential deposition (UPD) method. ${ }^{88}$ Due to the stabilization effects from the Au clusters, the oxidation of $\mathrm{Pt}$ active sites on $\mathrm{Au} / \mathrm{Pt} / \mathrm{C}$ catalyst is strongly decreased. As a result, both the ECSA and the ORR activity of the $\mathrm{Au} / \mathrm{Pt} / \mathrm{C}$ catalyst almost remains the same after 30,000 cycles potential cycling from $0.6-1.1 \mathrm{~V}$ in $\mathrm{O}_{2}$-saturated $0.1 \mathrm{M} \mathrm{HClO}_{4}$. In contrast, the $\mathrm{Pt} / \mathrm{C}$ catalyst suffers an ECSA loss of $45 \%$ and an ORR half-wave potential degradation of $39 \mathrm{mV}$. Zhou et al also reported an increased catalyst durability of an ethylene glycol reduction method prepared $\mathrm{Pt}_{3} \mathrm{Pd} / \mathrm{C}$ catalyst. Due to the weakening effect of Pd on Pt-O bond, the addition of Pd reduced the formation of surface Pt oxides and increased the stability of the catalyst. After 500 cycles of potential cycling from $0.6-1.2 \mathrm{~V}$ in $\mathrm{N}_{2}$ saturated $0.5 \mathrm{M} \mathrm{H}_{2} \mathrm{SO}_{4}$, the ECSA loss of $\mathrm{Pt}_{3} \mathrm{Pd} / \mathrm{C}$ is $55 \%$, which is lower than that of commercial $\mathrm{Pt} / \mathrm{C}$ catalyst (65\%). However, the increasing of durability is only achieved at the sacrifice of the intrinsic catalytic activity; the absolute ORR activities of both $\mathrm{Au} / \mathrm{Pt} / \mathrm{C}$ and $\mathrm{Pt}_{3} \mathrm{Pd} / \mathrm{C}$ are lower than that of $\mathrm{Pt} / \mathrm{C}$ catalyst, under the same testing conditions.

Recently, one-dimensional (1D) nanostructures have been emerging as a new approach to avoid the agglomerations of 0D nanoparticles. Chen et al. prepared a Pt nanotube (NT) with an average diameter of $50 \mathrm{~nm}$, a wall thickness of $4-7 \mathrm{~nm}$, and a length of $1-5$ $\mu \mathrm{m} .{ }^{89}$ As the Ostwald ripening and aggregation are both eliminated by the micrometersized length of the Pt-NT, $>80 \%$ ECSA survived after 1,000 cycles of accelerated durability test. In contrast, the ECSA of Pt/C dropped down to $<15 \%$. However, due to its large wall thickness and its inaccessible inner tube surface area, its initial ECSA is very small $\left(<15 \mathrm{~m}^{2} \mathrm{~g}^{-1}\right)$, which greatly limits the ORR mass activity enhancement. 
(a) Growth via Modified Ostwald Ripening

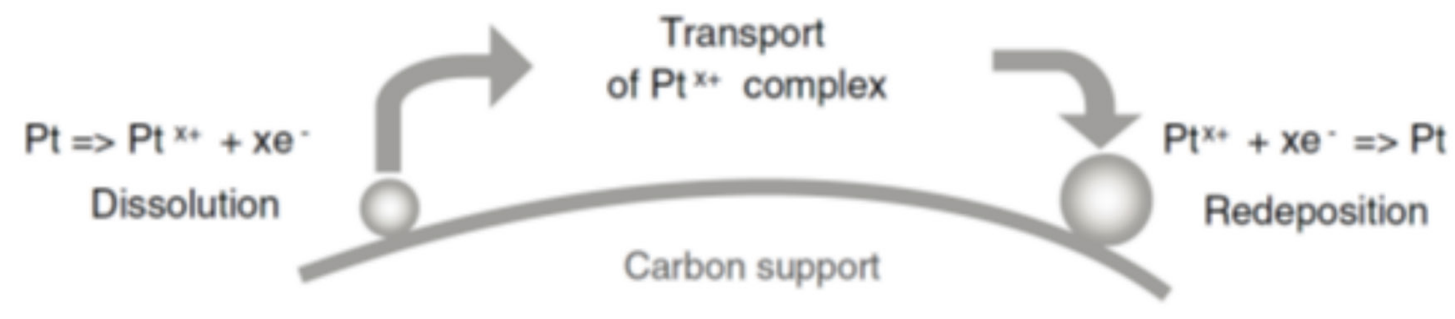

(b) Coalescence via Crystal Migration

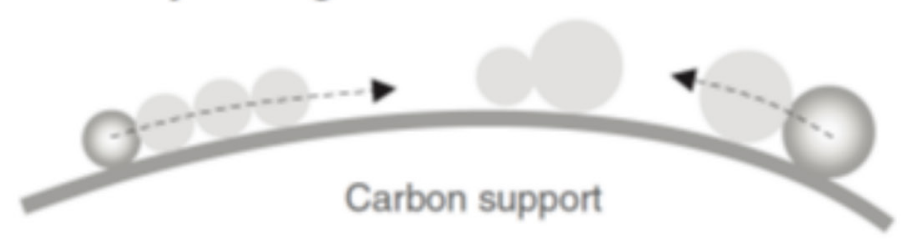

(c) Detachment from carbon support

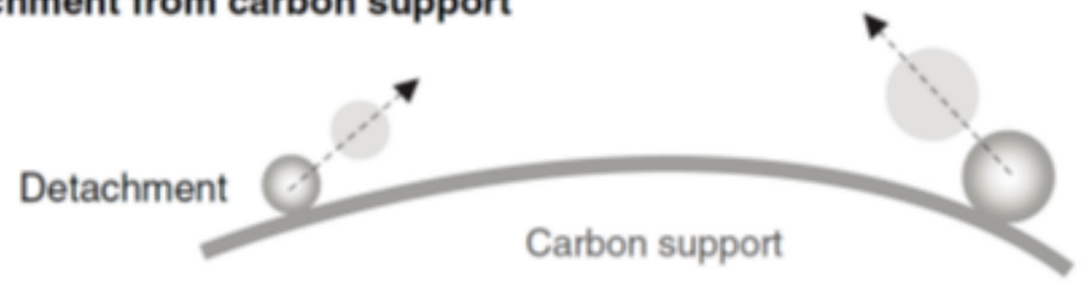

(d) Dissolution and Precipitation in the lon Conductor

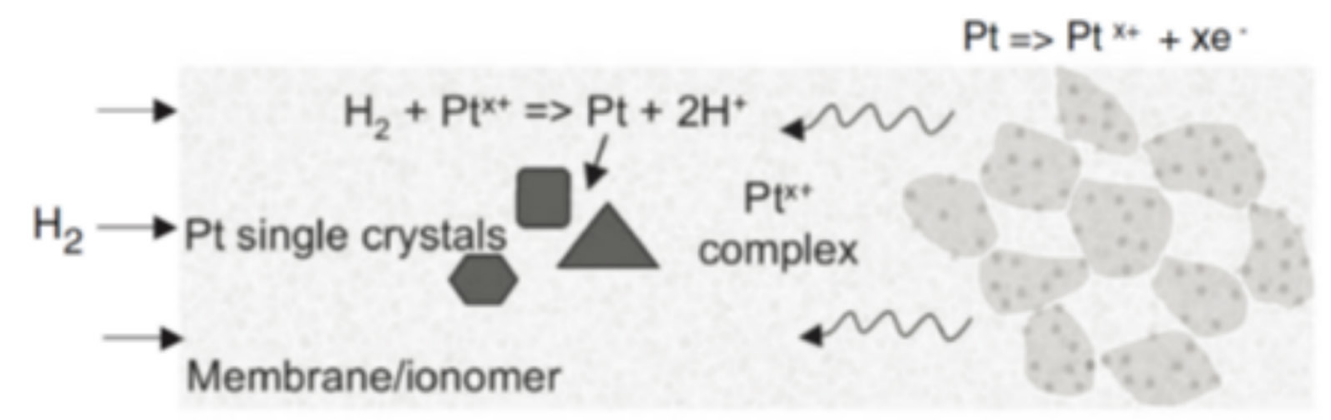

Fig. 3.3 Proposed mechanisms of instability of Pt nanoparticles in low temperature fuel cells ${ }^{87}$.

Tan et al recently developed $\mathrm{Au} / \mathrm{Pt}$ and $\mathrm{Au} / \mathrm{Pt}_{3} \mathrm{Ni}$ nanowire (NW) catalysts by growing the $\mathrm{Pt}$ or $\mathrm{Pt}_{3} \mathrm{Ni}$ nanodendritic structures on a Au nanowire support. ${ }^{90}$ Owing to the higher 
stability of the Au nanowire and the stronger interaction between the Au nanowire and the $\mathrm{Pt}$ or $\mathrm{Pt}_{3} \mathrm{Ni}$ nanodendrites, the $\mathrm{Au} / \mathrm{Pt}$ and $\mathrm{Au} / \mathrm{Pt}_{3} \mathrm{Ni}$ nanowire catalysts demonstrated higher durability than commercial $\mathrm{Pt} / \mathrm{C}$ catalyst. After 5,000 potential sweeps in $\mathrm{O}_{2}$ saturated $0.1 \mathrm{M} \mathrm{HClO}_{4}$ between 0.6 and $1.1 \mathrm{~V}$, the ECSAs of the $\mathrm{Au} / \mathrm{Pt}$ and $\mathrm{Au} / \mathrm{Pt}_{3} \mathrm{Ni}$ nanowire catalysts dropped only by $6.8 \%$ and $9.9 \%$, respectively, while that of $\mathrm{Pt} / \mathrm{C}$ catalyst reduced by $37.9 \%$. Meanwhile, due to the small size of the nanodendrite structures $(<3 \mathrm{~nm})$, the $\mathrm{Au} / \mathrm{Pt}$ and $\mathrm{Au} / \mathrm{Pt}_{3} \mathrm{Ni}$ also demonstrated a higher utilization of $\mathrm{Pt}$ and a better ORR activity. However, use of a large amount of $\mathrm{Au}$ as a catalyst backbone/support will definitely increase the cost of the catalysts preparation.

Another method to increase the durability of the fuel cell cathode catalyst is to use higher corrosion-resistant supports. Publications on CNTs, highly graphitized carbon, and graphene, have demonstrated that carbon supports with higher graphitization degree are able to effectively anchor Pt-based nanoparticles from agglomeration and improve catalyst life time. Wang et al compared the stabilities of multi-wall carbon nanotube (MWCNT) and Vulcan carbon black supported Pt catalysts by a CA test in $\mathrm{N}_{2}$-purged 0.5 $\mathrm{M} \mathrm{H}_{2} \mathrm{SO}_{4}$ at $0.9 \mathrm{~V} v$ s. SHE for over 168 hours, and confirmed that the highly graphitized MWCNT supported Pt catalyst suffered a corrosion current lower than three fourths that of Pt/C. Corresponding, only $37 \%$ of its original ECSA was lost on Pt/MWCNT after 168 hours of oxidation, while that on $\mathrm{Pt} / \mathrm{C}$ was up to almost $80 \%$.

Another elegant piece of work has been recently carried out by Watanabe's group. ${ }^{91}$ The group synthesized Pt/graphitized carbon (Pt/GC) catalysts based on an organic phase reduction method, and compared its durability with that of commercial Pt/GC (c-Pt/GC) and commercial $\mathrm{Pt} / \mathrm{C}(\mathrm{c}-\mathrm{Pt} / \mathrm{CB})$ by a potential step cycles $(0.9$ and $1.3 \mathrm{~V}$, alternatively, each for 30 second) in $0.1 \mathrm{M} \mathrm{HClO}_{4}$ at $25^{\circ} \mathrm{C}$. The results show that when the ECSA dropped to half of its original value, the time elapse of $\mathrm{n}-\mathrm{Pt} / \mathrm{GC}$ was 12 and 22 times that of c-Pt/GC and c-Pt/CB. By comparing the STEM images of these three catalysts before and after the durability tests, it has been found that all of the three catalysts have a remarkable size increase. However, in $\mathrm{c}-\mathrm{Pt} / \mathrm{CB}$, many $\mathrm{Pt}$ particles have been found detached from the CB support, some part of Pt particles detached from the support in c- 
$\mathrm{Pt} / \mathrm{GC}$, while few of them detached in the case of $\mathrm{n}-\mathrm{Pt} / \mathrm{GC}$. This result indicates that the corrosion resistance ability of support holds significant importance to the durability of catalysts. In addition, it is interesting to discover that the dispersion of catalysts on support is also of great importance: the small inter-particle distance will also lead to coalescence.

In this chapter, ultra-thin $\mathrm{Pt}_{\mathrm{x}} \mathrm{Fe}_{\mathrm{y}}$ nanowires (NWs) were prepared as robust catalysts for ORR. The $\mathrm{Pt}_{\mathrm{x}} \mathrm{Fe}_{\mathrm{y}}-\mathrm{NWs}$ with a diameter of $2-3 \mathrm{~nm}$ were successfully prepared through a solution-phase reduction method at Pt-Fe compositions from 1:1 to 2:1. The carbon supported $\mathrm{Pt}_{\mathrm{x}} \mathrm{Fe}_{\mathrm{y}}-\mathrm{NWs}\left(\mathrm{Pt}_{\mathrm{x}} \mathrm{Fe}_{\mathrm{y}}-\mathrm{NWs} / \mathrm{C}\right)$ demonstrated higher ORR activity and better electro-chemical durability than conventional $\mathrm{Pt} / \mathrm{C}$ catalyst. After 1000 cycles of $0-1.3$ $\mathrm{V}$ (vs. SHE), the relative ECSA of $\mathrm{Pt}_{2} \mathrm{Fe}_{1}-\mathrm{NW} / \mathrm{C}$ dropped down to $46 \%$, which was 2 times better than $\mathrm{Pt} / \mathrm{C}$ catalyst, and the mass activity at $0.85 \mathrm{~V}$ ( $v s$. SHE) for $\mathrm{Pt}_{1} \mathrm{Fe}_{1}$ $\mathrm{NW} / \mathrm{C}$ was $39.9 \mathrm{~mA} / \mathrm{mg}_{\mathrm{Pt}}$, which is twice $\mathrm{Pt} / \mathrm{C}\left(18.6 \mathrm{~mA} / \mathrm{mg}_{\mathrm{Pt}}\right)$.

\subsection{Experimental}

\subsubsection{Synthesis of $\mathrm{Pt}_{\mathrm{x}} \mathrm{Fe}_{\mathrm{x}}-\mathrm{NWs}$}

The synthesis procedure of $\mathrm{Pt}_{1} \mathrm{Fe}_{1}-\mathrm{NWs}$ is described as follows: ${ }^{92-94} 197 \mathrm{mg}$ of $\mathrm{Pt}(\mathrm{acac})_{2}$ $(0.5 \mathrm{mmol})$ was first dissolved in $20 \mathrm{ml}$ of oleylamine at $60^{\circ} \mathrm{C}$, under the protection of $\mathrm{N}_{2}$ gas flow. The temperature was then quickly raised to $120^{\circ} \mathrm{C}$, and was kept at that temperature for 30 minutes. $120 \mu \mathrm{l}$ of $\mathrm{Fe}(\mathrm{CO})_{5}(1.0 \mathrm{mmol})$ was then injected into the synthesis system. The system was then heated to $160^{\circ} \mathrm{C}$ and was held at that temperature for another 30 minutes before it was cooled down to room temperature (RT) by removing the mantle heater. $10 \mathrm{ml}$ of hexanes and $50 \mathrm{ml}$ of ethanol were mixed with the obtained suspension and the product was separated by centrifugation (8,000 rpm for 10 minutes). The product was further cleaned by being redispersed in $5 \mathrm{ml}$ of hexanes and precipitated by adding $25 \mathrm{ml}$ of ethanol, and was separated by centrifugation at the same conditions. 
The procedure was repeated three times and the final product $\mathrm{Pt}_{1} \mathrm{Fe}_{1}-\mathrm{NW}$ was stored in 10 $\mathrm{ml}$ of hexanes.

Following similar procedures, $60 \mu \mathrm{l}(0.5 \mathrm{mmol})$ and $24 \mu \mathrm{l}(0.2 \mathrm{mmol})$ were injected to prepare $\mathrm{Pt}_{2} \mathrm{Fe}_{1}-\mathrm{NW}$ and $\mathrm{Pt}_{5} \mathrm{Fe}_{1}-\mathrm{NW}$, respectively.

\subsubsection{Physical characterizations}

The morphologies and structures of the $\mathrm{Pt}_{\mathrm{x}} \mathrm{Fe}_{\mathrm{y}}-\mathrm{NWs}$ were analyzed by Z-contrast transmission electron microscopy (Hitachi HD2000 STEM). The compositions of the $\mathrm{Pt}_{\mathrm{x}} \mathrm{Fe}_{\mathrm{y}}-\mathrm{NWs}$ were determined by energy dispersive X-ray spectroscopy (EDX) connected to a JEOL JEM-4000JX TEM instrument with an operating voltage of $200 \mathrm{kV}$. XRD patterns of the $\mathrm{Pt}_{\mathrm{x}} \mathrm{Fe}_{\mathrm{y}}-\mathrm{NWs}$ were collected following the procedure described in Section 2.2.5.

\subsubsection{Electro-chemical studies}

The ECSAs, durabilities, and ORR activities of the $\mathrm{Pt}_{\mathrm{x}} \mathrm{Fe}_{\mathrm{y}}-\mathrm{NWs}$ were investigated in half cell setups (see Section 2.3.1). Before testing, $1.0 \mathrm{mg}$ of $\mathrm{Pt}_{\mathrm{x}} \mathrm{Fe}_{\mathrm{y}}-\mathrm{NWs}$ (dispersed in hexanes) was deposited on $4.0 \mathrm{mg}$ carbon black (dispersed in ethanol by sonication for 1 hour) to make $\mathrm{Pt}_{\mathrm{x}} \mathrm{Fe}_{\mathrm{y}}-\mathrm{NW} / \mathrm{C}$ catalysts. The working electrode with $\mathrm{Pt}_{\mathrm{x}} \mathrm{Fe}_{\mathrm{y}}-\mathrm{NW}$ catalyst or commercial $\mathrm{Pt} / \mathrm{C}$ catalyst was prepared by the procedure mentioned in Section 2.3.1.1.

The durabilities of $\mathrm{Pt}_{\mathrm{x}} \mathrm{Fe}_{\mathrm{y}}-\mathrm{NW} / \mathrm{C}$ catalysts and commercial $\mathrm{Pt} / \mathrm{C}$ catalyst were evaluated by a 1000 -cycle CV scan from $0-1.3 \mathrm{~V}$ (vs. SHE) in $0.5 \mathrm{M} \mathrm{H}_{2} \mathrm{SO}_{4}$, at the sweep rate of $50 \mathrm{mV} \mathrm{s}^{-1}$. The ECSA was calculated based on the hydrogen underpotential desorption peak: ${ }^{95}$

$$
S_{e}=\frac{Q_{r}}{m \times C}
$$


where $\mathrm{m}$ is the mass of $\mathrm{Pt}$ on the GCE, $\mathrm{Q}_{\mathrm{r}}$ is the hydrogen underpotential desorption charge, and $\mathrm{C}$ is the charge density constant $\left(0.21 \mathrm{mC} \mathrm{cm}^{-2}\right.$ for Pt polycrystals). $\mathrm{Q}_{\mathrm{r}}$ is calculated by the equation:

$$
Q_{r}=\frac{1}{v} \int_{a}^{b}\left(I-I_{d l}\right) d E
$$

where $v$ is the sweep rate, $a$ and $b$ are $0 \mathrm{~V}$ and $0.4 \mathrm{~V}$ (vs. SHE), which are the starting and stopping potentials for the hydrogen underpotential desorption on Pt polycrystals, and $\mathrm{I}_{\mathrm{dl}}$ is the current generated from double layer charging, which is assumed to be a constant.

The rotating disk electrode (RDE)-based ORR activities on these catalysts were measured by a linear scan voltammetry (LSV), performed in $\mathrm{O}_{2}$-saturated $0.5 \mathrm{M} \mathrm{H}_{2} \mathrm{SO}_{4}$ from 0 $1.2 \mathrm{~V}$ (vs.SHE). The ORR activities on these catalysts were presented by the kinetic current density $\left(i_{k}\right)$, calculated by equation (2-7), which is derived from the LevichKoutecky equation: ${ }^{96}$

$$
i_{k}=\frac{i \times i_{d}}{i_{d}-i}
$$

The mass activity (MA) is obtaining by normalizing the kinetic current $\left(\mathrm{i}_{\mathrm{k}} \times \mathrm{A}\right)$ with the $\mathrm{Pt}$ loading on the GCE:

$$
\mathrm{MA}=\frac{i_{k} \times A}{m_{P t}}
$$

\subsection{Results and discussion}

\subsubsection{Physical characterizations}

The chemical compositions of $\mathrm{Pt}: \mathrm{Fe}$ in the $\mathrm{Pt}_{\mathrm{x}} \mathrm{Fe}_{\mathrm{y}}-\mathrm{NWs}$ were determined by TEM-EDX, which are 0.8:1, 2.4:1, and 4.0:1 for $\mathrm{Pt}_{1} \mathrm{Fe}_{1}, \mathrm{Pt}_{2} \mathrm{Fe}_{1}$, and $\mathrm{Pt}_{5} \mathrm{Fe}_{1}-\mathrm{NWs}$, respectively. It is interesting that the $\mathrm{Fe}(\mathrm{CO})_{5}$ that was initially injected was only partially incorporated into the $\mathrm{Pt}_{\mathrm{x}} \mathrm{Fe}_{\mathrm{y}}-\mathrm{NWs}$, due to the evaporation of a portion of the $\mathrm{Fe}(\mathrm{CO})_{5}$ under the reaction temperature $\left(120-160^{\circ} \mathrm{C}\right)$, which is higher than its boiling point of $104^{\circ} \mathrm{C} .^{94,97}$ 
The XRD patterns collected from $\mathrm{Pt}_{\mathrm{x}} \mathrm{Fe}_{\mathrm{y}}-\mathrm{NWs}$ and commercial Pt/C are shown in Fig. 3.4. The diffraction peak at $25.1^{\circ}$ is attributed to the (002) graphitic facet of carbon in $\mathrm{Pt} / \mathrm{C}$ catalyst, while the diffraction peaks at $2 \theta=39.7^{\circ}, 46.2^{\circ}, 67.3^{\circ}$, and $81.2^{\circ}$ are assigned to the Pt (111), (200), (220), and (311) diffraction peaks, respectively. In all XRD patterns of $\mathrm{Pt}_{\mathrm{x}} \mathrm{Fe}_{\mathrm{y}}-\mathrm{NWs}$, no diffraction peak of $\mathrm{Fe}$ has been observed, indicating that the $\mathrm{Fe}$ has formed an alloy with $\mathrm{Pt}$ or is in amorphous phases. ${ }^{95,98,99}$ The average metal crystal sizes of commercial $\mathrm{Pt} / \mathrm{C}$ and as-prepared $\mathrm{Pt}_{\mathrm{x}} \mathrm{Fe}_{\mathrm{y}}-\mathrm{NWs}$ are calculated by the Debye-Scherrer formula (equation 2-1): ${ }^{95,100,101}$

$$
L=\frac{0.9 \lambda_{K_{\alpha}}}{B_{2 \theta} \cos \theta_{\max }}
$$

The results yielding from (220) peaks for $\mathrm{Pt} / \mathrm{C}, \mathrm{Pt}_{5} \mathrm{Fe}_{1}, \mathrm{Pt}_{2} \mathrm{Fe}_{1}$, and $\mathrm{Pt}_{1} \mathrm{Fe}_{1}$-nanowires are $1.8,4.2,3.0$ and $2.6 \mathrm{~nm}$, respectively. As the Fe amount in the catalysts increases, the diffraction peaks shift to the right (marked by the dash lines for (111) and (220) peaks in Fig. 3.5). The lattice parameters of $\mathrm{Pt} / \mathrm{C}$ and $\mathrm{Pt}_{\mathrm{x}} \mathrm{Fe}_{\mathrm{y}}-\mathrm{NWs}$ were calculated from $\mathrm{Pt}(220)$ diffract peaks using equation (2-2), which are 3.942, 3.902, 3.882, $3.871 \AA$ for $\mathrm{Pt} / \mathrm{C}$, $\mathrm{Pt}_{5} \mathrm{Fe}_{1}, \mathrm{Pt}_{2} \mathrm{Fe}_{1}, \mathrm{Pt}_{1} \mathrm{Fe}_{1}$, respectively. The result shows that a better Pt-Fe alloy structure was formed with the Fe amount increasing in the catalysts. It is interesting to point out that the lattice parameter of $\mathrm{Pt}_{1} \mathrm{Fe}_{1}-\mathrm{NWs}$ is very close to that of $\mathrm{Pt}_{1} \mathrm{Fe}_{1}$ solid solution (3.877 $\AA$, PDF 29-717), indicating a formation of ideal solution phase formed in these nanowires. 

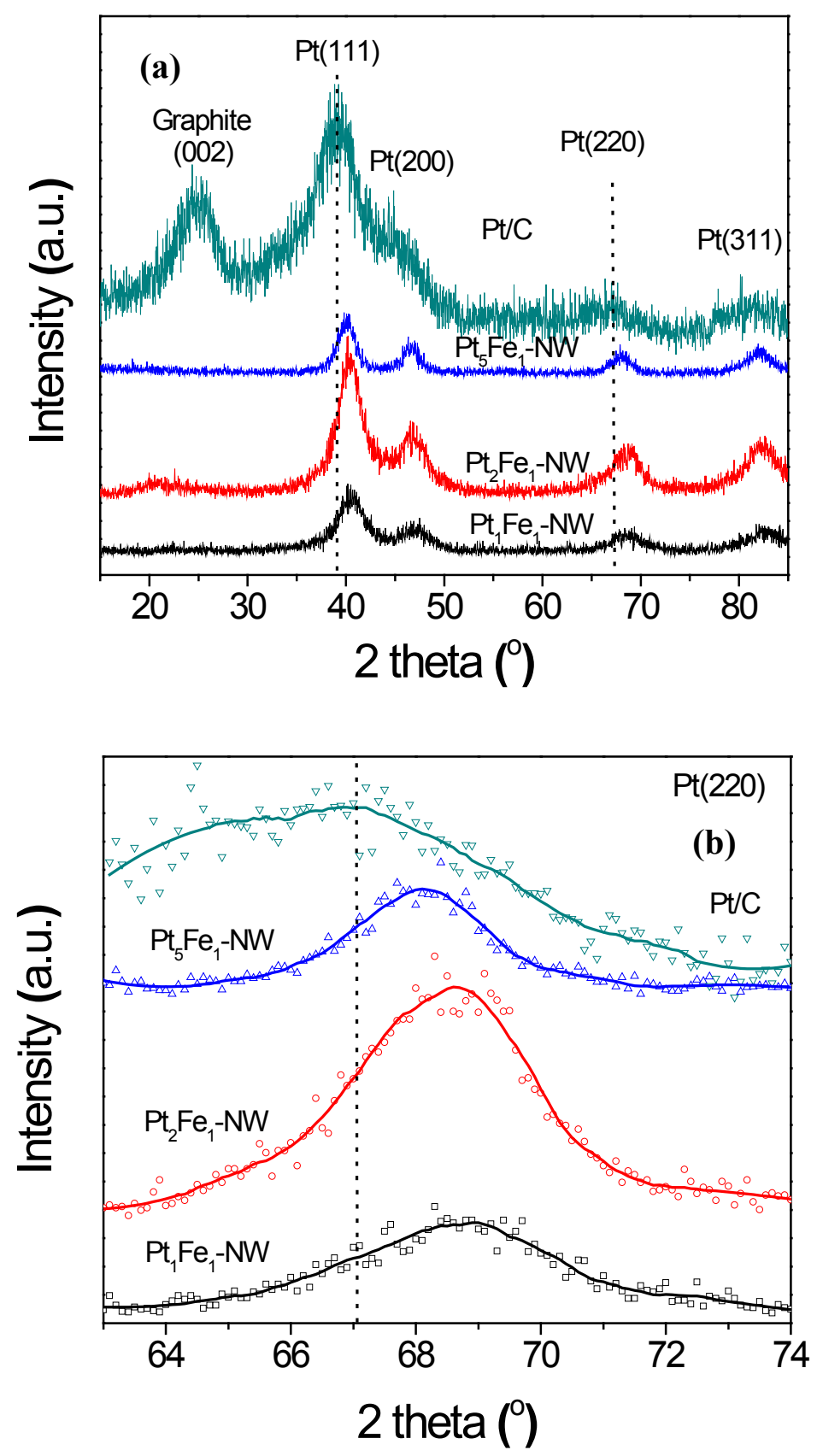

Fig. 3.4 (a) XRD patterns of $\mathrm{Pt}_{\mathrm{x}} \mathrm{Fe}_{\mathrm{y}}-\mathrm{NWs}(1: 1,2: 1$, and 5:1) and commercial Pt/C catalyst; (b) detailed Pt (220) diffraction peaks.

Typical TEM images of the $\mathrm{Pt}_{\mathrm{x}} \mathrm{Fe}_{\mathrm{y}}-\mathrm{NWs}$ are shown in Fig. 3.5. It can be found that $\mathrm{Pt}_{\mathrm{x}} \mathrm{Fe}_{\mathrm{y}}-\mathrm{NWs}$ can be successfully synthesized at a Pt-Fe composition range of 1:1 - 2:1. The average diameters are $2.7 \mathrm{~nm}$ for the $\mathrm{Pt}_{1} \mathrm{Fe}_{1}-\mathrm{NW}$ and $2.9 \mathrm{~nm}$ for the $\mathrm{Pt}_{2} \mathrm{Fe}_{1}-\mathrm{NW}$, which are in good agreement with the XRD results. It is not easy to measure the lengths 
of the $\mathrm{Pt}_{\mathrm{x}} \mathrm{Fe}_{\mathrm{y}}-\mathrm{NWs}$ due to their curved formation. However, when comparing Fig. 3.5 (a) and (b), it is quite obvious that with the Fe amount decreasing, the nanowires become shorter and thicker. When the atom ratio of Pt to Fe further increases to 5: 1, the majority of the nanostructures are particles, and minority short rods (shown in Fig. 3.5 (c)). The $\mathrm{Pt}_{5} \mathrm{Fe}_{1}$ nanostructures have an average diameter of $4.2 \mathrm{~nm}$ with a broad size distribution. Comparison of TEM images of the three samples leads to a conclusion that the $\mathrm{Fe}$ amount in this synthesis plays a critical role on the shape and size of the products. At higher Fe concentrations, long and thin nanowires can be predominantly produced, while at low Fe concentrations, the major products are nanoparticles with a larger diameter. During the synthesis, OAm works as a solvent, surfactant, and reductant, and selforganizes into an elongated reverse-micelle-like structure, ${ }^{94}$ with a higher density of surfactant on the sides of $\mathrm{Pt}_{\mathrm{x}} \mathrm{Fe}_{\mathrm{y}}-\mathrm{NWs}$, and a little on the tips and ends. Therefore, atoms are more likely to be attached/added on the tips and ends, leading to the formation of NW structure. The Fe atom is likely to couple with the $\mathrm{Pt}$ atom through a spin-orbit coupling and hybridization between $\mathrm{Fe} 3 \mathrm{~d}$ and $\mathrm{Pt} 5 \mathrm{~d}$ states, ${ }^{102,103}$ and incorporated into $\mathrm{Pt}$ fcc crystalline structure to form a uniform phase. ${ }^{94}$ This incorporation of $\mathrm{Fe}$ into $\mathrm{Pt}$ crystalline structure is also evidenced by the XRD pattern, by the shift of Pt diffraction peak to a higher $2 \theta$ angle and the disappearance of Fe diffraction peak. Reducing the amount of $\mathrm{Fe}$ changes the coupling between $\mathrm{Pt}$ and $\mathrm{Fe}$, and therefore will affect the morphology of $\mathrm{Pt}_{\mathrm{x}} \mathrm{Fe}_{\mathrm{y}}$-NWs. ${ }^{97}$ 

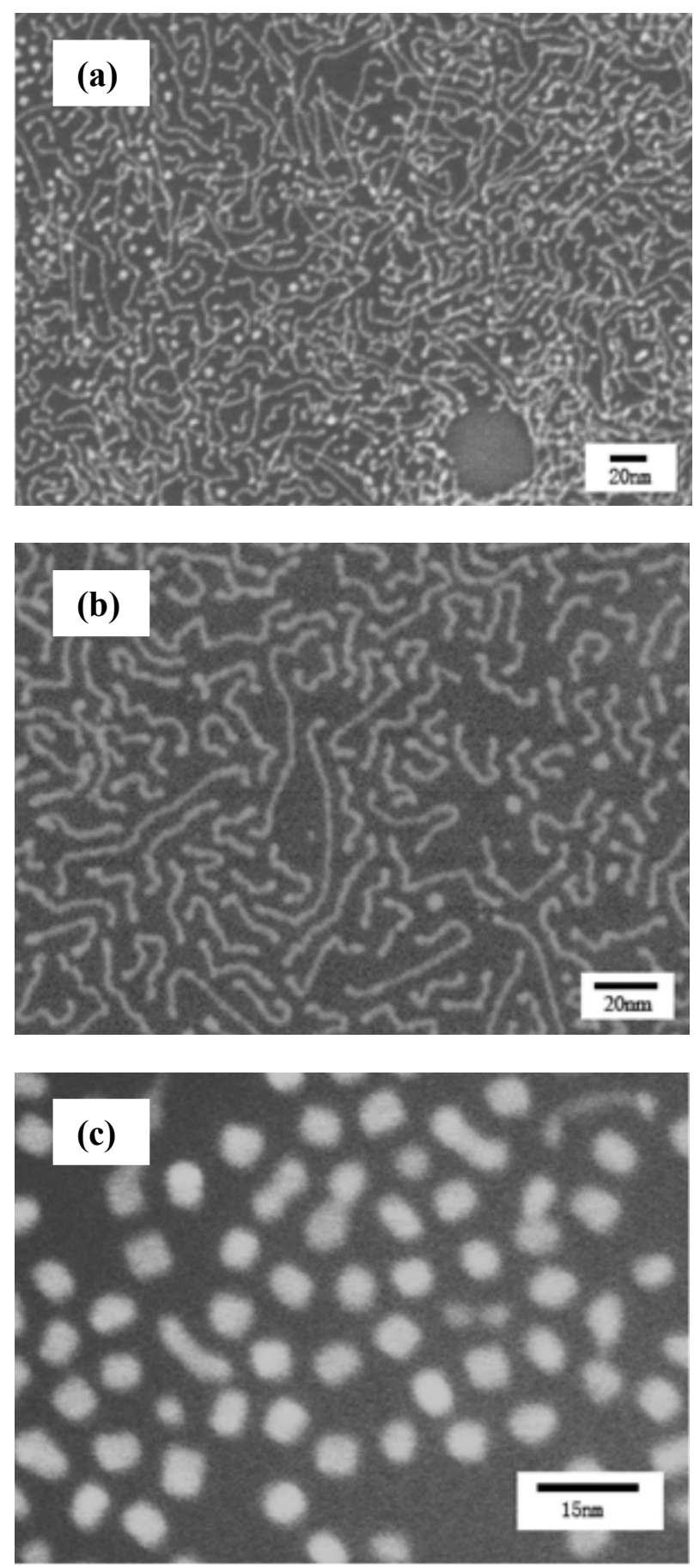

Fig. 3.5 TEM images of (a) $\mathrm{Pt}_{1} \mathrm{Fe}_{1}-\mathrm{NW}$; (b) $\mathrm{Pt}_{2} \mathrm{Fe}_{1}-\mathrm{NW}$; and (c) $\mathrm{Pt}_{5} \mathrm{Fe}_{1}-\mathrm{NW}$. 
A typical HR-TEM image of $\mathrm{Pt}_{1} \mathrm{Fe}_{1}-\mathrm{NW}$ is shown in Fig. 3.6. The interfringe distance was measured to be $0.198 \mathrm{~nm}$, indicating that the side of the NW is covered by Pt (100) planes. This result is in good agreement with other publications that the $\mathrm{Pt}_{\mathrm{x}} \mathrm{Fe}_{\mathrm{y}}-\mathrm{NW}$ grows along $\mathrm{Pt}(100)$ direction. ${ }^{94}$

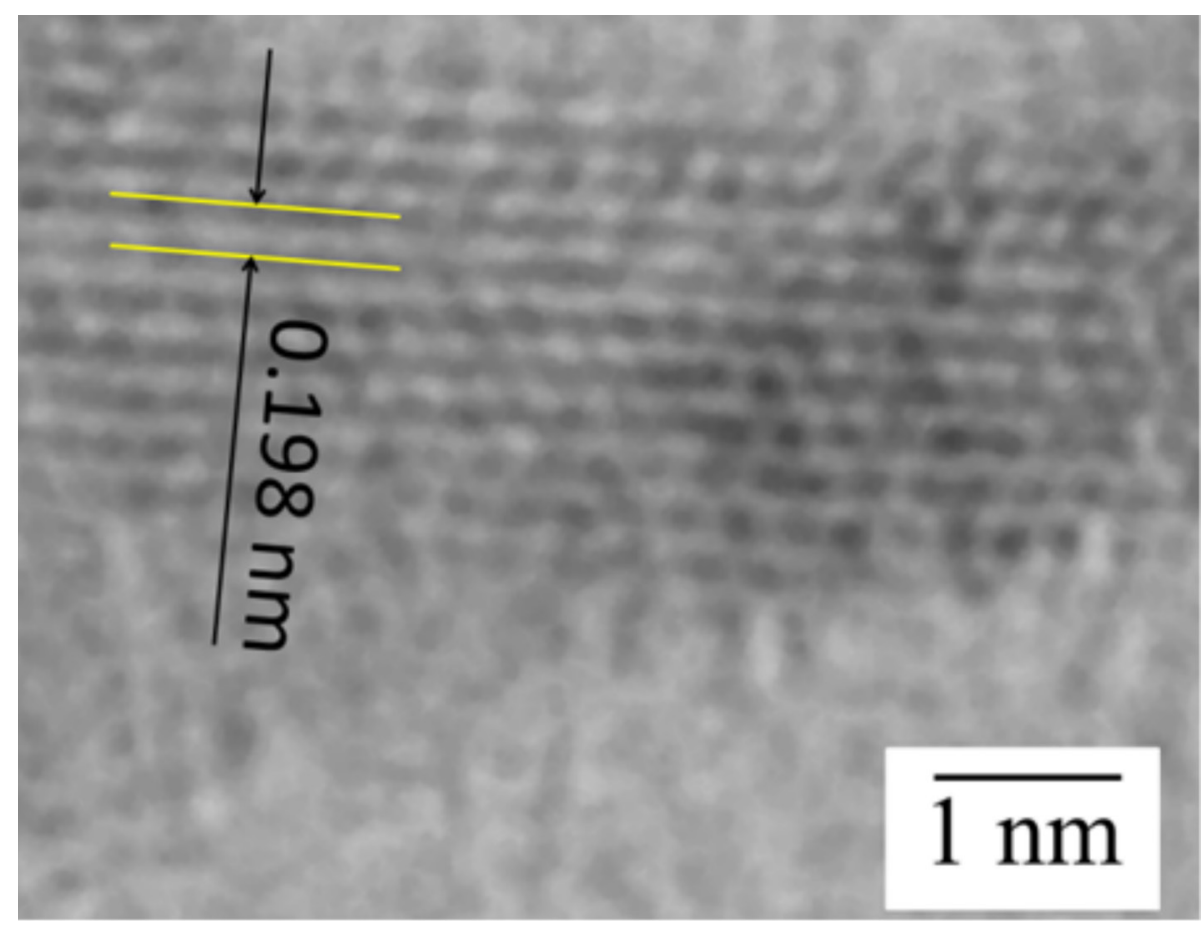

Fig. 3.6 HR-TEM image of $\mathrm{Pt}_{1} \mathrm{Fe}_{1}-\mathrm{NW}$.

\subsubsection{Electro-chemical characterization}

The durability of the $\mathrm{Pt}_{\mathrm{x}} \mathrm{Fe}_{\mathrm{y}}-\mathrm{NWs}$ and the $\mathrm{Pt} / \mathrm{C}$ catalysts were evaluated by the accelerated $\mathrm{CV}$-based tests in $0.5 \mathrm{M} \mathrm{H}_{2} \mathrm{SO}_{4}$. The cyclic voltammograms for the $\mathrm{Pt}_{\mathrm{x}} \mathrm{Fe}_{\mathrm{y}^{-}}$ NWs and the Pt/C catalysts before and after 1,000 cycles are summarized in Fig. 3.7. Comparing to the cathode catalyst assembled in MEA, in which only the parts of Pt contacting with the ionomer are active, the catalysts tested in three-electrode setups are completely exposed to the liquid electrolyte. ${ }^{32}$ In addition, the CV scan range of $0-1.3 \mathrm{~V}$ is a big challenge to the $\mathrm{Pt}$ (the redox potential of $\mathrm{Pt} / \mathrm{Pt}^{2+}$ is $1.19 \mathrm{~V}$ ), the deterioration of the catalysts is accelerated. Therefore, as shown in Fig. 3.7, the hydrogen underpotential 
desorption peaks on all of these catalysts are remarkably suppressed after the accelerated durability tests, due to the aggregation and dissolution of Pt-nanostructures. The original ECSA of $\mathrm{Pt}_{1} \mathrm{Fe}_{1}-\mathrm{NW} / \mathrm{C}, \mathrm{Pt}_{2} \mathrm{Fe}_{1}-\mathrm{NW} / \mathrm{C}, \mathrm{Pt}_{5} \mathrm{Fe}_{1}-\mathrm{NW} / \mathrm{C}$ and $\mathrm{Pt} / \mathrm{C}$ calculated from their corresponding hydrogen underpotential desorption peaks are 52.2, 45.6, 38.5, and 61.4 $\mathrm{m}^{2} \mathrm{~g}^{-1}$, respectively. Although the commercial Pt/C demonstrates a better initial ECSA, it is noted that the $\mathrm{Pt}$ utilization is $76 \%$ for $\mathrm{Pt}_{1} \mathrm{Fe}_{1}-\mathrm{NW} / \mathrm{C}$, which is nearly twice as that of $\mathrm{Pt} / \mathrm{C}(40 \%)$. The relative ECSA losses are plotted in Fig. 3.8. After 1000 cycles, the relative ECSA loss of $\mathrm{Pt}_{\mathrm{x}} \mathrm{Fe}_{\mathrm{y}}-\mathrm{NWs} / \mathrm{C}$ is less than $\mathrm{Pt} / \mathrm{C}$ catalysts. The absolute ECSA of $\mathrm{Pt}_{2} \mathrm{Fe}_{1}-\mathrm{NW} / \mathrm{C}$ after 1000 cycles remains $21 \mathrm{~m}^{2} / \mathrm{g}$ (46\% of its original ECSA), which is nearly twice than that of the Pt/C catalyst $\left(12 \mathrm{~m}^{2} / \mathrm{g}, 20 \%\right.$ of its original ECSA). It is interesting to find that $\mathrm{Pt}_{1} \mathrm{Fe}_{1}-\mathrm{NW} / \mathrm{C}$ has a remarkable increase in ECSA within the first 150 cycles. This is probably because the leaching out of $\mathrm{Fe}$ in the few monolayers of the NW structure, ${ }^{104}$ which will leave a highly active Pt-rich surface. This trend can also be observed in the $\mathrm{Pt}_{2} \mathrm{Fe}_{1}-\mathrm{NW} / \mathrm{C}$ sample, which also has a small increase at around 50 cycles. The better durability of $\mathrm{Pt}_{x} \mathrm{Fe}_{y}-\mathrm{NWs} / \mathrm{C}$ may lie in two possible reasons: 1) The nanowire samples have a very large aspect ratio comparing to $\mathrm{Pt} / \mathrm{C}$ catalysts. Therefore, the nanowires do not easily aggregate as nanoparticles, which has been identified as a major cause for the surface area reduction for nanoparticle ( 0 -D sphere) electro-catalysts. ${ }^{86}$ ) The spin orbit coupling and the hybrization of between Fe $3 \mathrm{~d}$ and Pt $5 \mathrm{~d}$ states will lead to an enhancement of the chemical stability of PtFe alloy, ${ }^{94,97}$ and further result in the durability improvement of $\mathrm{Pt}_{\mathrm{x}} \mathrm{Fe}_{\mathrm{y}}$-NWs. 

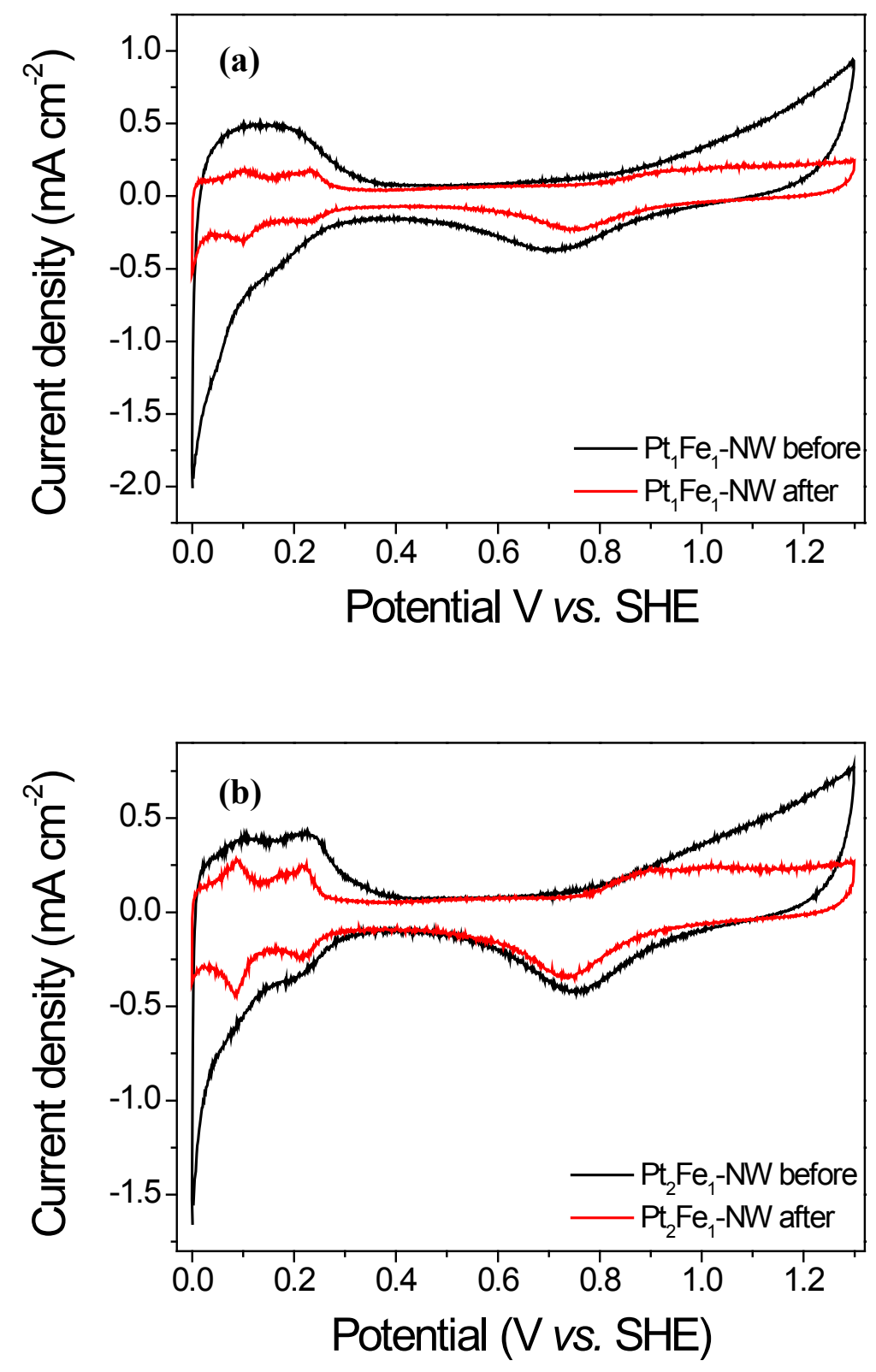

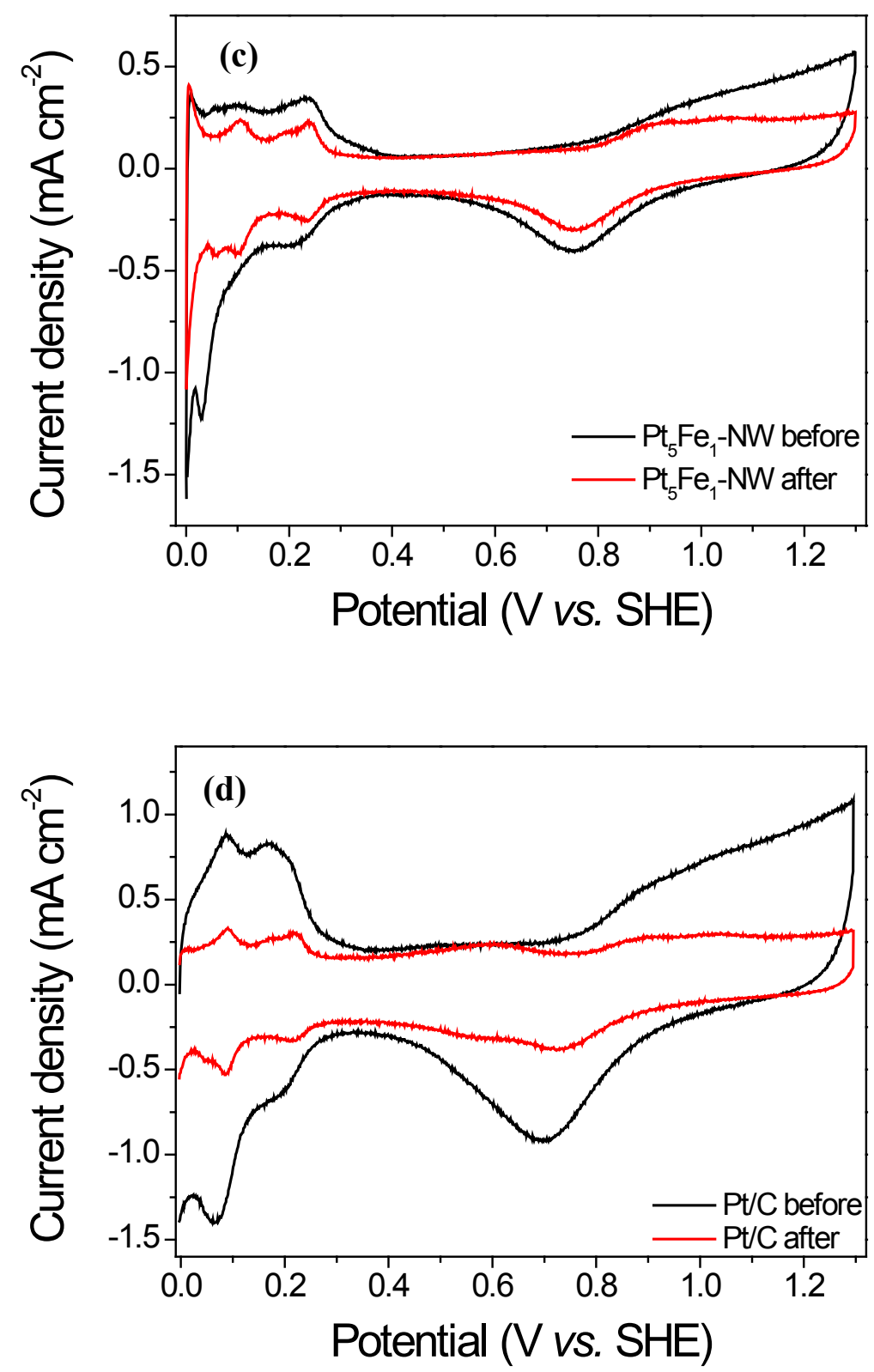

Fig. 3.7 Cyclic voltammograms of $\mathrm{Pt}_{\mathrm{x}} \mathrm{Fe}_{\mathrm{y}}-\mathrm{NWs}((\mathrm{a})-(\mathrm{c}))$ and the $\mathrm{Pt} / \mathrm{C}$ (d) catalysts, before and after the accelerated durability tests 


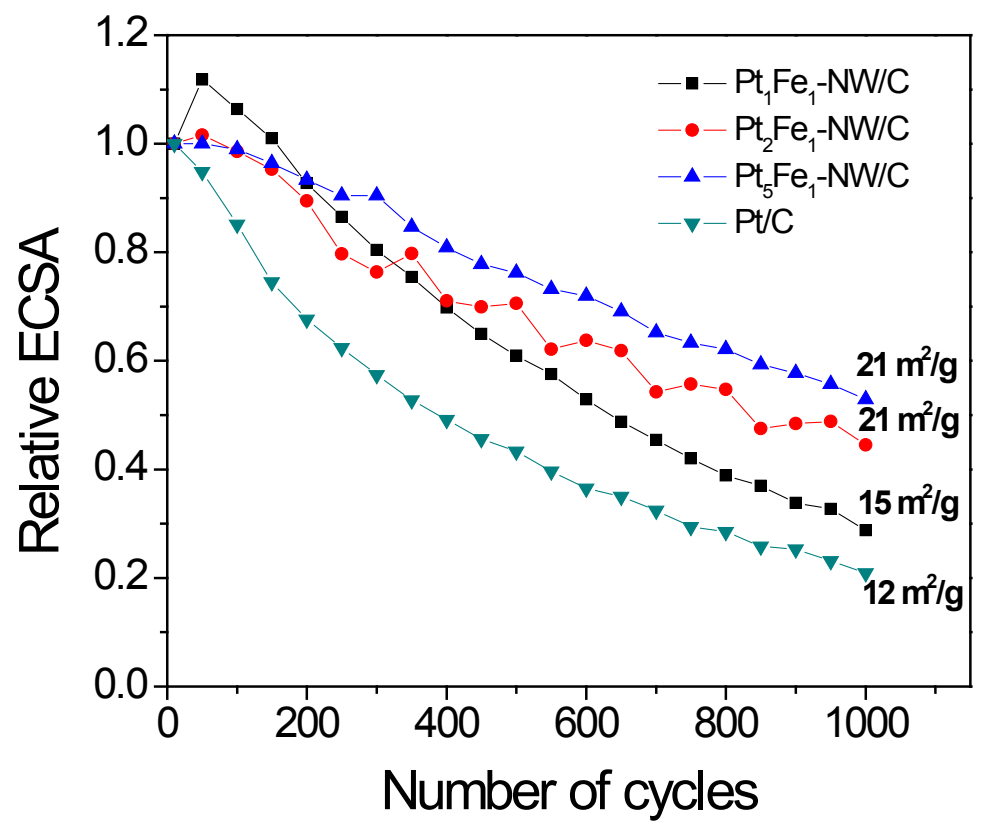

Fig. 3.8 Accelerated durability tests on $\mathrm{Pt}_{\mathrm{x}} \mathrm{Fe}_{\mathrm{y}}-\mathrm{NW}(1: 1,2: 1,5: 1) / \mathrm{C}$ and $\mathrm{Pt} / \mathrm{C}$ catalysts in $0.5 \mathrm{M} \mathrm{H}_{2} \mathrm{SO}_{4}, 0-1.3 \mathrm{~V}$ vs. SHE, survived ECSAs after 1,000 cycles are listed on the right side.

Meanwhile, $\mathrm{Pt}_{\mathrm{x}} \mathrm{Fe}_{\mathrm{y}}-\mathrm{NWs} / \mathrm{C}$ catalysts also exhibit higher ORR activity when compared with that of the commercial $\mathrm{Pt} / \mathrm{C}$ catalyst in the course of the durability test. The ORR polarization curves of $\mathrm{Pt}_{1} \mathrm{Fe}_{1}-\mathrm{NWs} / \mathrm{C}$ and $\mathrm{Pt} / \mathrm{C}$ catalysts are shown in Fig. 3.9. The initial onset potential of $\mathrm{Pt}_{1} \mathrm{Fe}_{1}-\mathrm{NWs}$ is $0.95 \mathrm{~V}$ (vs. SHE), which is $0.02 \mathrm{~V}$ lower than that of the commercial Pt/C (0.93 V vs. SHE), while after the durability test, the onset potential of the $\mathrm{Pt}_{1} \mathrm{Fe}_{1}-\mathrm{NWs} / \mathrm{C}(0.93 \mathrm{~V}$ vs. SHE) still lower than that of the $\mathrm{Pt} / \mathrm{C}(0.92 \mathrm{~V}$ vs. SHE), indicating a better catalytic property of $\mathrm{Pt}_{1} \mathrm{Fe}_{1}-\mathrm{NWs} / \mathrm{C}$ towards ORR reaction exited throughout the durability test. The enhanced ORR activity of $\mathrm{Pt}_{1} \mathrm{Fe}_{1}-\mathrm{NWs} / \mathrm{C}$ can also be proved by the kinetic currents density $\left(i_{k}\right)$ calculated by equation $(2-7)$ :

$$
i_{k}=\frac{i \times i_{d}}{i_{d}-i}
$$

The diffusion limiting currents $\left(i_{d}\right)$ were collected at the region below $0.3 \mathrm{~V}$. After normalizing the kinetic currents with the metal loading by equation (3-5), $\mathrm{Pt}_{1} \mathrm{Fe}_{1}-\mathrm{NWs} / \mathrm{C}$ shows a MA of $77.1 \mathrm{~mA} \mathrm{mg}^{-1} \mathrm{Pt}$ at $0.85 \mathrm{~V}$, while that of the $\mathrm{Pt} / \mathrm{C}$ was $65.7 \mathrm{~mA} \mathrm{mg}^{-1} \mathrm{Pt}$. After the durability test, the MA of $\mathrm{Pt}_{1} \mathrm{Fe}_{1}-\mathrm{NWs}_{\mathrm{s}} / \mathrm{C}$ only decreased to $39.9 \mathrm{~mA} \mathrm{mg}{ }^{-1}$, 
which is twice that of the $\mathrm{Pt} / \mathrm{C}\left(18.6 \mathrm{~mA} \mathrm{mg}_{\mathrm{Pt}}^{-1}\right)$. The calculation of MA shows that $\mathrm{Pt}_{\mathrm{x}} \mathrm{Fe}_{\mathrm{y}}-\mathrm{NWs} / \mathrm{C}$ possesses both a higher ORR activity and better electro-chemical durability than commercial $\mathrm{Pt} / \mathrm{C}$ catalysts. While the better durability can be attributed to the high aspect ratio 1-D nanowire structure and the spin orbit coupling and the hybrization of between $\mathrm{Fe}$ and $\mathrm{Pt}$, the reasons for the better ORR activity may rise from the electronic effects. It is well known that the ORR activity can be enhanced through the modified electronic structure of Pt surface layer by underlying $\mathrm{M}(\mathrm{Fe}, \mathrm{Ni}, \mathrm{Co}$, etc) sublayer. ${ }^{104-107}$ The surface transition metal $\mathrm{Fe}$ with a redox potential much lower than precious metal Pt, which will leach out under electro-chemical cycling, and could lead to formation of Pt-rich shell nanostructures. ${ }^{104}$ The adsorption energy of oxygen on surface Pt will be reduced by the sub-layer Fe atoms, resulting in a better ORR activity than that of commercial $\mathrm{Pt} / \mathrm{C}$ catalyst.

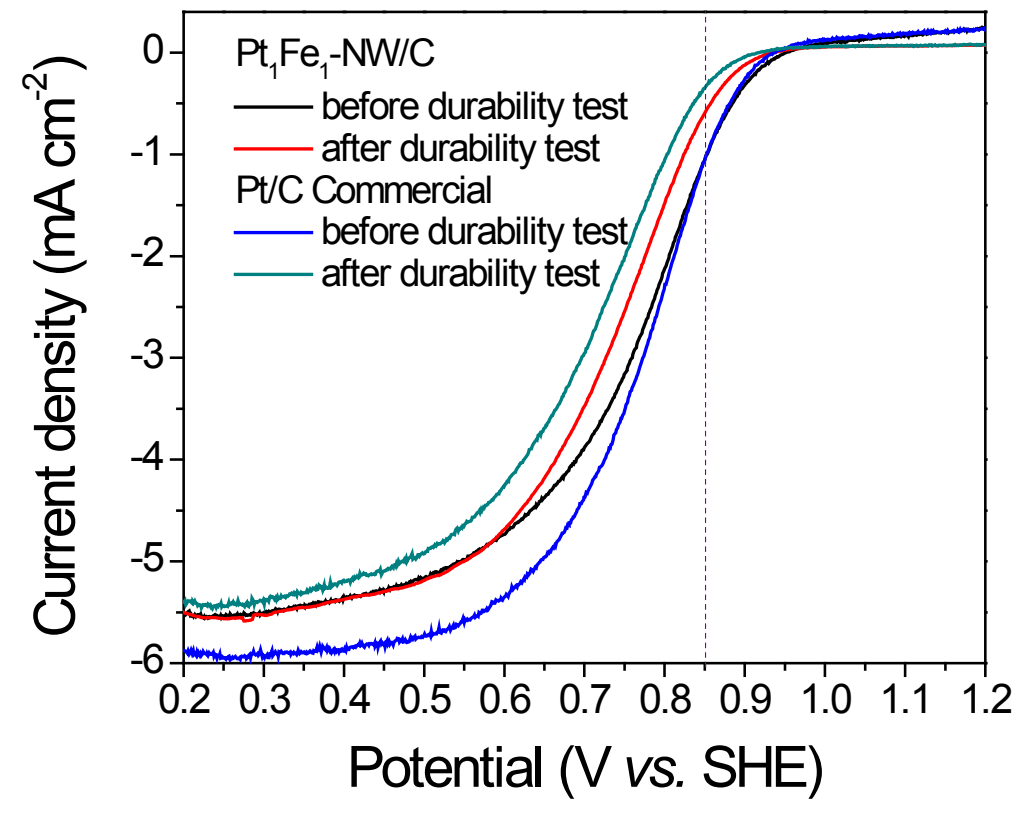

Fig. 3.9 ORR polarization curves of $\mathrm{Pt}_{1} \mathrm{Fe}_{1}-\mathrm{NWs}$ and commercial $\mathrm{Pt} / \mathrm{C}$ catalysts before and after the accelerated durability test, test conditions: $0.5 \mathrm{M} \mathrm{H}_{2} \mathrm{SO}_{4}, 2500 \mathrm{rpm}$, room temperature. 


\subsection{Conclusion}

In this study, ultra-thin $\mathrm{Pt}_{\mathrm{x}} \mathrm{Fe}_{\mathrm{y}}-\mathrm{NWs}$ were successfully prepared through a solution-phase reduction route. The $\mathrm{Pt}_{\mathrm{x}} \mathrm{Fe}_{\mathrm{y}}-\mathrm{NWs} / \mathrm{C}$ have higher electro-chemical surface areas and $\mathrm{Pt}$ utilization (i.e. $52 \mathrm{~m}^{2} / \mathrm{g}$ and $76 \%$ for $\mathrm{Pt}_{1} \mathrm{Fe}_{1}-\mathrm{NW} / \mathrm{C}$ ). They can survive better than $\mathrm{Pt} / \mathrm{C}$ under accelerated electro-chemical cycling tests. It is very interesting to find that $\mathrm{Pt}_{\mathrm{x}} \mathrm{Fe}_{\mathrm{y}^{-}}$ NWs an enhanced intrinsic ORR activity comparing to commercial Pt/C. Therefore, the ultra-thin nanowires show great potentials as promising fuel cell electro-catalysts. 


\section{Chapter 4 Pd-Fe nanoleaves as electro-catalysts for ORR in alkaline electrolyte*}

\subsection{Introduction}

\subsubsection{Background}

Alkaline fuel cells or alkaline electrolyte fuel cells were extensively studied between 1960s -1980 s. ${ }^{108}$ However, they gradually lost their popularity to the newly emerged proton-exchange membrane fuel cells (PEMFCs), which are more flexible and eliminated the electrolyte carbonation and leakage problems. However, fuel cells have to meet three criteria before commercialization: cost, performance, and durability. From this point of view, the widespread application of PEMFC is obstructed by its sluggish ORR kinetics and its heavy dependence on high price Pt-based catalysts. Recently, novel solid alkaline membranes have been developed and demonstrated a high anion exchange conductivity and carbonate tolerance, ${ }^{109-113}$ thereby leading to the resurgence of the low-temperature anion-exchange membrane fuel cells (AEMFCs). ${ }^{114-116}$ The anion-exchange membrane fuel cell (AEMFC) possesses numerous advantages over PEMFC on both cathode kinetics and ohmic polarizations. ${ }^{117}$ Comparing to the PEMFC, the less corrosive nature of AEMFC ensures a higher durability of cathode catalyst. ${ }^{115}$ The relatively lower cathode working potentials enables the application of non-Pt oxygen reduction catalysts. In addition, the lower adsorption of spectator ions and the improved charge/ion transfer in alkaline environment greatly promoted the kinetics of oxygen reduction reaction. ${ }^{24,28,118-}$ ${ }^{122}$ These advantages of AEMFC make it more attractive for ORR catalysts in high $\mathrm{pH}$ media.

\footnotetext{
*The material contained in this chapter was previously published in Chemistry of Materials. Reprinted with permission from Chemistry of Materials 2011; 23(6), Zhiyong Zhang, Karren L. More, Kai Sun, Zili Wu, and Wenzhen Li, "Preparation and characterization of PdFe nanoleaves as electrocatalysts for oxygen reduction reaction", 1570-1577. Copyright 2011American Chemical Society.
} 


\subsubsection{Thermodynamics in $\mathrm{H}_{2} / \mathrm{O}_{2}$ AEMFC}

Different from the PEMFC where $\mathrm{H}^{+}$is the charge carrier, in an AEMFC, the $\mathrm{OH}^{-}$is transported from the cathode to the anode. The anode reaction is as follows: ${ }^{109}$

$$
2 \mathrm{H}_{2}+4 \mathrm{OH}^{-} \longrightarrow 4 \mathrm{H}_{2} \mathrm{O}+4 e^{-} \quad E_{a}^{0}=-0.828 \mathrm{~V} \text { vs. SHE }
$$

while at the cathode:

$$
\mathrm{O}_{2}+2 \mathrm{H}_{2} \mathrm{O}+4 e^{-} \longrightarrow 4 \mathrm{OH}^{-} \quad E_{c}^{0}=0.401 \mathrm{~V} \text { vs. SHE }
$$

The overall reaction is:

$$
2 \mathrm{H}_{2}+\mathrm{O}_{2} \longrightarrow 2 \mathrm{H}_{2} \mathrm{O} \quad E_{\text {cell }}^{0}=1.229 \mathrm{~V}
$$

\subsubsection{ORR mechanism in alkaline electrolyte}

A brief ORR pathway was proposed by Schmidt, et al. as shown in Fig 4.1. Similar to the ORR in acidic media, $\mathrm{O}_{2}$ is first adsorbed on catalysts to form $\mathrm{O}_{2}$, ad, then it could either be electro-chemically reduced directly by $\mathrm{k}_{1}$ path to form $\mathrm{OH}^{-}$by a 4-e path, or go through a set of pathway through the intermediate of $\mathrm{HO}_{2 \text {, ad }}^{-}$by $\mathrm{k}_{2}$ path. The adsorbed $\mathrm{HO}_{2}^{-}$could further go through $\mathrm{k}_{3}$ path to form $\mathrm{OH}^{-}\left(2+2 \mathrm{e}^{-}\right)$, or desorbed into the bulk of the solution, or even be catalytically decomposed back to $\mathrm{O}_{2}$ and water.

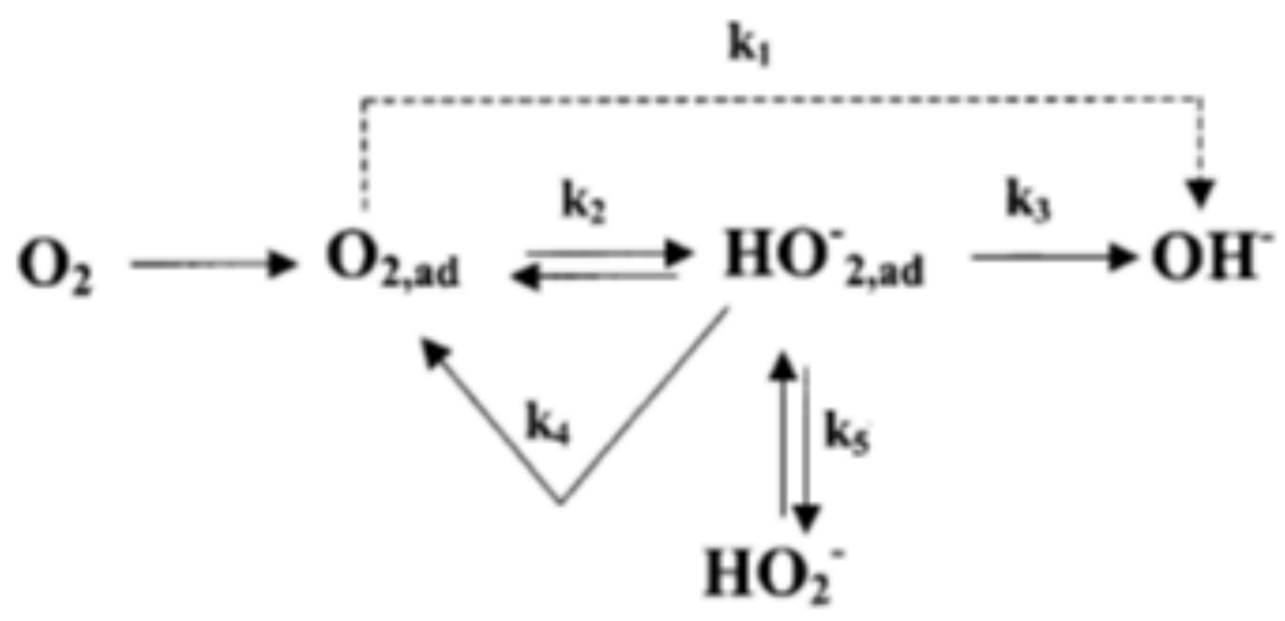

Fig. 4.1 Proposed schemes for oxygen reduction reaction (ORR) in alkaline media ${ }^{31}$. 


\subsubsection{Non-Pt ORR catalysts in alkaline media}

One of the most attractive advantages of AEMFC is its relatively mild cathode catalyst working conditions, which enables the use of a series of non-Pt ORR catalysts, including non-Pt metal catalysts: $\mathrm{Pd},{ }^{119,123-125} \mathrm{Rh},{ }^{119,126} \mathrm{Ir},{ }^{119} \mathrm{Ru},{ }^{119,127} \mathrm{PdFe},{ }^{128,129} \mathrm{PdAg},{ }^{130-133}$ $\mathrm{PdNi},{ }^{120}$, and $\mathrm{Ag},{ }^{134-137}$, etc; transition cheap metal - macrocomponds catalysts: Fe-, ${ }^{138}$ $\mathrm{Co}-,{ }^{139,140} \mathrm{FeCu}-,{ }^{141,142}$ based nitrogen-containing organic macro-compounds; and nonmetal catalysts: N-doped CNT, ${ }^{143-146} \mathrm{~N}$-doped carbon sphere, ${ }^{147} \mathrm{~N}$-doped mesoporous carbon, ${ }^{148}, \mathrm{~N}$-doped graphene, ${ }^{149}$ iodine-doped graphene. ${ }^{150}$ However, among these catalysts, only Pd and Pd-based catalysts possess intrinsic ORR activities competitive to $\mathrm{Pt}$, and are most widely studied. Jiang et al. investigated the ORR on $\mathrm{Pd} / \mathrm{C}$ and $\mathrm{Pt} / \mathrm{C}$ in alkaline solutions, and demonstrated a lower peroxide yields on $\mathrm{Pd} / \mathrm{C}$ at the mixed kinetic-diffusion control region. ${ }^{122} \mathrm{Pt}$ (111) single crystal covered by a monolayer of $\mathrm{Pd}$ has demonstrated higher intrinsic ORR activity than $\mathrm{Pt}(111)$ in $0.1 \mathrm{M} \mathrm{KOH}$, which is due to an optimization of the balance between the kinetics of O-O bond breakage and electroreduction of the intermediates. ${ }^{28} \mathrm{Pd}-\mathrm{Ni}$ alloy nanoparticles are reported to be able to facilitate a high number of electron-transfer during oxygen reduction in high $\mathrm{pH}$ media, and thus exhibit a comparable ORR activity as $\mathrm{Pt}$, which is attributed to Pd lattice shrinkage due to the incorporation of $\mathrm{Ni}^{120}$ There is an imperative need to explore novel Pd nanostructures with advantageous facets and/or optimized electronic properties to further improve the ORR activity in alkaline electrolyte.

In this chapter, Pd-Fe nanoleaves (NLs) have been prepared through an organic solution phase reduction synthesis route. The morphology investigations clearly show this newlydeveloped structure is assembled from Pd-rich nanowires (NWs) surrounded by Fe-rich sheets. The Pd-NWs have a diameter in range of $1.8-2.3 \mathrm{~nm}$ and a large electrochemical surface area of $>50 \mathrm{~m}^{2} \mathrm{~g}^{-1}$. By etching away the enveloping Fe-rich sheets using an organic acid, the Pd-rich NWs are exposed on the surface of nanoleaves, and they demonstrated high reactivity towards electro-catalytic reduction of oxygen in a 0.1 
$\mathrm{M} \mathrm{NaOH}$ electrolyte: $3.0 \times$ increase in the specific activity and $2.7 \times$ increase in the mass activity compared with a commercial $\mathrm{Pt} / \mathrm{C}$ catalyst (at $0 \mathrm{~V} v s . \mathrm{Hg} / \mathrm{HgO} / 1.0 \mathrm{M} \mathrm{NaOH}$ ).

\section{2 Experimental}

\subsubsection{Synthesis of $P d_{x} F e_{y}-N L s$}

$\mathrm{Pd}_{\mathrm{x}} \mathrm{Fe}_{\mathrm{y}}-\mathrm{NLs}(\mathrm{Pd}-\mathrm{Fe}$ atomic ratio: 1:1, 2:1, and 5:1) were prepared through a solution

phase reduction approach. ${ }^{92,93}$ The synthesis of $\mathrm{Pd}_{1} \mathrm{Fe}_{1}-\mathrm{NL}$ is described as follows: a mixture of $153 \mathrm{mg}$ of $\mathrm{Pd}(\mathrm{acac})_{2}(0.5 \mathrm{mmol})$ and $20 \mathrm{ml}$ of oleylamine $(\mathrm{OAm})$ was rapidly heated to $105^{\circ} \mathrm{C}$ under a blanket of nitrogen, at which time $120 \mu 1$ of $\mathrm{Fe}(\mathrm{CO})_{5}(1.0 \mathrm{mmol})$ was immediately injected into the synthesis system. The temperature was held at $105^{\circ} \mathrm{C}$ for 20 minutes, and then raised to $160^{\circ} \mathrm{C}$ and held for an additional 30 minutes. The solution was cooled to room temperature by removing the mantle heater. A mixture of 10 $\mathrm{ml}$ of hexane and $50 \mathrm{ml}$ of ethanol was added, and the product was separated by centrifuging at $8,000 \mathrm{rpm}$ for 10 minutes. The product was then cleaned by re-dispersing it in a mixture of $5 \mathrm{ml}$ of hexane and $25 \mathrm{ml}$ of ethanol and then separating it by centrifuging. This is done for three more times. The final $\mathrm{Pd}_{1} \mathrm{Fe}_{1}-\mathrm{NL}$ ( $\mathrm{Pd}-\mathrm{Fe}$ atomic ratio: 1:1) sample was stored in $10 \mathrm{ml}$ of hexane. Following a similar procedure, $60 \mu \mathrm{l}(0.5$ $\mathrm{mmol})$ and $24 \mu \mathrm{l}(0.2 \mathrm{mmol})$ of $\mathrm{Fe}(\mathrm{CO})_{5}$ were injected in the synthesis solutions to prepare $\mathrm{Pd}_{2} \mathrm{Fe}_{1}-\mathrm{NL}$ and $\mathrm{Pd}_{5} \mathrm{Fe}_{1}-\mathrm{NL}$, respectively. To investigate the effect of synthesis conditions on the nanoleaves morphology, $120 \mu 1$ of $\mathrm{Fe}(\mathrm{CO})_{5}$ was injected into the system at different temperatures, $60^{\circ} \mathrm{C}$ (immediately at this temperature) and $105^{\circ} \mathrm{C}$ (after aging at this temperature for 20 minute), the samples were named $\mathrm{Pd}_{1} \mathrm{Fe}_{1}-\mathrm{NL}-\mathrm{B}$, and $\mathrm{Pd}_{1} \mathrm{Fe}_{1}-\mathrm{NL}-\mathrm{C}$, respectively. 


\subsubsection{Preparation of carbon supported $\mathrm{Pd}_{\mathrm{x}}-\mathrm{NLs}$}

Appropriate amount of $\mathrm{Pd}_{\mathrm{x}} \mathrm{Fe}_{\mathrm{y}}-\mathrm{NL}$ was deposited on carbon black through the procedure in Section 2.1.2 to obtain carbon supported $\mathrm{Pd}_{\mathrm{x}} \mathrm{Fe}_{\mathrm{y}}-\mathrm{NL}$ sample (including $\mathrm{Pd}_{5} \mathrm{Fe}_{1}-\mathrm{NL} / \mathrm{C}$, $\mathrm{Pd}_{2} \mathrm{Fe}_{1}-\mathrm{NL} / \mathrm{C}$ and $\mathrm{Pd}_{1} \mathrm{Fe}_{1}-\mathrm{NL} / \mathrm{C}$ ) with a Pd loading of around $20 \mathrm{wt} . \%$. To remove the Fe-rich sheets that enveloped the Pd-rich NWs, an organic acid treatment was performed. In detail, $100 \mathrm{mg}$ of the as-prepared $\mathrm{Pd}_{\mathrm{x}} \mathrm{Fe}_{\mathrm{y}}-\mathrm{NL} / \mathrm{C}$ sample was dispersed in $20 \mathrm{ml}$ of hexane under sonication to form a uniform ink. This was followed by an injection of 20 $\mathrm{ml}$ of acetic acid and heating at $70^{\circ} \mathrm{C}$ for 10 hours. After the system was cooled to room temperature, $50 \mathrm{ml}$ of acetone was added and the product was separated by centrifuging the mixture at 5,000 rpm for $5 \mathrm{~min}$. The product was washed in $20 \mathrm{ml}$ of acetone four more times to remove all the acetic acid, and then dried at $40^{\circ} \mathrm{C}$ overnight. After the organic acid treatment, the resulting product from the $\mathrm{Pd}_{x} \mathrm{Fe}_{y}-\mathrm{NL} / \mathrm{C}$ was designated as $\mathrm{Pd}_{\mathrm{x}} \mathrm{-NL} / \mathrm{C}$ (since most of Fe has been corroded away).

\subsubsection{Preparation of carbon supported Pd}

Serving as a control sample, a $\mathrm{Pd} / \mathrm{C}(20 \mathrm{wt} \%)$ was synthesized through our wellestablished ethylene glycol (EG) reduction method, ${ }^{44,100}$ which can be briefly described as follows: $106 \mathrm{mg}$ of carbon black was dispersed uniformly in $25 \mathrm{~mL}$ of EG under sonication and a solution of $5 \mathrm{~mL}$ EG containing $58 \mathrm{mg} \mathrm{Pd}\left(\mathrm{NO}_{3}\right)_{2}$ was then added into the system dropwisely. A solution of $1.0 \mathrm{M} \mathrm{NaOH}$ (in EG) was added to adjust the $\mathrm{pH}$ of the synthesis solution to above 13 , and then the mixture was heated at $135^{\circ} \mathrm{C}$ for 3 hours to reduce the Pd completely. After the system cooled down to room temperature, the $\mathrm{pH}$ of the synthesis system was adjusted to $1-2$ by $1.0 \mathrm{M} \mathrm{HCl}$. The $\mathrm{Pd} / \mathrm{C}$ catalyst was obtained after filtration, washing, and drying at $70^{\circ} \mathrm{C}$ overnight. 


\subsubsection{Physical characterizations}

The composition, morphology, and structure of the NLs were analyzed by X-ray diffraction (XRD), high-resolution transmission electron microscopy (HR-TEM), high angle annular dark field (HAADF) scanning transmission electron microscopy (S/TEM) coupled with high-spatial-resolution energy dispersive spectroscopy (EDS), scanning electron microscopy (SEM). X-ray photoelectron spectroscopy (XPS), inductively coupled plasma atomic emission spectroscopy (ICP-AES), and thermogravimetry analysis (TGA).

\subsubsection{Electro-chemical tests}

Cyclic voltammetry (CVs) tests and rotating disk electrode (RDE)-based ORR activity tests of the $\mathrm{Pd}_{\mathrm{x}}-\mathrm{NLs}, \mathrm{Pd} / \mathrm{C}$, and commercial $\mathrm{Pt} / \mathrm{C}$ (20 wt\%, E-TEK) catalysts were investigated at room temperature, with a $\mathrm{Hg} / \mathrm{HgO} / 1.0 \mathrm{M} \mathrm{NaOH}$ reference electrode $(0.140 \mathrm{~V}$ vs. NHE). The working electrode was prepared through the procedure elucidated in Section 2.3.1.1. The CV tests were performed from $-0.87-0.50 \mathrm{~V}$ (vs. $\mathrm{Hg} / \mathrm{HgO} / 1.0 \mathrm{M} \mathrm{NaOH}$ ) for 20 cycles. To exclude the hydrogen penetration/multi-layer absorption issues on $\mathrm{Pd}$, the $\mathrm{PdO}$ reduction peak was chosen instead of the hydrogen desorption peak to evaluate the ECSA, which was calculated by modified equation (2-3):

$$
S_{e}=\frac{Q_{r}}{m \times C}
$$

where $\mathrm{m}$ is the mass of $\mathrm{Pd}$ on the GCE, $\mathrm{Q}_{\mathrm{r}}$ is the $\mathrm{PdO}$ reduction charge, and $\mathrm{C}$ is the charge density constant $\left(0.405 \mathrm{mC} \mathrm{cm}^{-2}\right.$ for Pd polycrystals). $\mathrm{Q}_{\mathrm{r}}$ is calculated by the equation:

$$
Q_{r}=\frac{1}{v} \int_{a}^{b}\left(I-I_{d l}\right) d E
$$

where $v$ is the sweep rate of $50 \mathrm{mV} \mathrm{s}^{-1}$, a and $\mathrm{b}$ are $-0.05 \mathrm{~V}$ and $-0.50 \mathrm{~V}(v s . \mathrm{Hg} / \mathrm{HgO} / 1.0$ $\mathrm{M} \mathrm{NaOH}$ ), which are the starting and stopping potentials for the PdO reduction peak, and $I_{\mathrm{dl}}$ is the current generated from double layer charging. 
For the ORR activity test, a linear scan from $-0.80-0.20 \mathrm{~V}(v s . \mathrm{Hg} / \mathrm{HgO} / 1.0 \mathrm{M} \mathrm{NaOH})$ was conducted on the catalyst in $0.1 \mathrm{M} \mathrm{NaOH}$ at room temperature and ambient pressure. The kinetic current density $\left(i_{k}\right)$ was calculated using equation (2-7):

$$
i_{k}=\frac{i \times i_{d}}{i_{d}-i}
$$

where $i$ is the current density collected from the working electrode, and $i_{d}$ is the diffusion limiting current density collected at the region below $-0.3 \mathrm{~V}(v s . \mathrm{Hg} / \mathrm{HgO} / 1.0 \mathrm{M} \mathrm{NaOH})$.

The mass activity (MA) is calculated by normalizing the $\mathrm{i}_{\mathrm{k}}$ with the $\mathrm{Pd}$ loading on the GCE:

$$
\mathrm{MA}=\frac{i_{k} \times A}{m_{P d}}
$$

\subsection{Results and discussion}

\subsubsection{Physical characterizations}

The bulk chemical compositions of $\mathrm{Pd}_{\mathrm{x}} \mathrm{Fe}_{\mathrm{y}}-\mathrm{NL} / \mathrm{C}$ catalysts were determined by ICP-AES. As shown in Table 4. 1, the atomic ratio of $\mathrm{Pd}: \mathrm{Fe}$ in the $\mathrm{Pd}_{\mathrm{x}} \mathrm{Fe}_{\mathrm{y}}-\mathrm{NL}$ catalysts is $0.98: 1$ for $\mathrm{Pd}_{1} \mathrm{Fe}_{1}-\mathrm{NL}$, 1.97:1 for $\mathrm{Pd}_{2} \mathrm{Fe}_{1}-\mathrm{NL}$, and 4.92:1 for $\mathrm{Pd}_{5} \mathrm{Fe}_{1}-\mathrm{NL}$. It is interesting to note that the initially injected $\mathrm{Fe}(\mathrm{CO})_{5}$ was only partially incorporated into the $\mathrm{Pd}_{\mathrm{x}} \mathrm{Fe}_{\mathrm{y}}-\mathrm{NL}$ catalysts, i.e. only $0.51 \mathrm{mmol} F e$ was incorporated in $\mathrm{Pd}_{1} \mathrm{Fe}_{1}-\mathrm{NL}$ at an injection of 1.0 mmol $\mathrm{Fe}(\mathrm{CO})_{5}$. This is due to the evaporation of a portion of the $\mathrm{Fe}(\mathrm{CO})_{5}$ at the aging temperature of $160^{\circ} \mathrm{C}$, which is higher than its boiling point of $104^{\circ} \mathrm{C} . .^{94,97}$ 
Table 4.1

Atomic composition, diameter, and lattice parameter of $\mathrm{Pd} / \mathrm{C}$ and $\mathrm{Pd}_{\mathrm{x}} \mathrm{Fe}_{\mathrm{y}}-\mathrm{NLs}$.

\begin{tabular}{|c|c|c|c|c|c|c|}
\hline & \multicolumn{2}{|c|}{$\begin{array}{l}\text { Atomic composition } \\
\text { (by ICP-AES) }\end{array}$} & \multicolumn{2}{|c|}{$\begin{array}{c}\text { Surface atomic } \\
\text { composition (by XPS) }\end{array}$} & \multirow{2}{*}{$\begin{array}{c}\text { Diameter } \\
\text { of Pd rich } \\
\text { NWs } \\
\text { (nm, by } \\
\text { TEM) }\end{array}$} & \multirow{2}{*}{$\begin{array}{c}\text { Lattice } \\
\text { parameter } \\
\text { (A, by } \\
\text { XRD) }\end{array}$} \\
\hline & $\begin{array}{c}\text { Before } \\
\text { acid } \\
\text { treatment }\end{array}$ & $\begin{array}{c}\text { After } \\
\text { acid } \\
\text { treatment }\end{array}$ & $\begin{array}{c}\text { Before } \\
\text { acid } \\
\text { treatment }\end{array}$ & $\begin{array}{l}\text { After acid } \\
\text { treatment }\end{array}$ & & \\
\hline $\mathrm{Pd} / \mathrm{C}$ & - & - & - & - & $4.2^{\mathrm{a}}$ & 3.891 \\
\hline $\mathrm{Pd}_{1} \mathrm{Fe}_{1}-\mathrm{NL}$ & $\mathrm{Pd}_{0.98} \mathrm{Fe}_{1}$ & $\mathrm{Pd}_{16.8} \mathrm{Fe}_{1}$ & $\mathrm{Pd}_{2} \mathrm{Fe}_{1}$ & $\mathrm{Pd}_{17.3} \mathrm{Fe}_{1}$ & 1.8 & 3.888 \\
\hline $\mathrm{Pd}_{2} \mathrm{Fe}_{1}-\mathrm{NL}$ & $\mathrm{Pd}_{1.97} \mathrm{Fe}_{1}$ & $\mathrm{Pd}_{11.4} \mathrm{Fe}_{1}$ & - & - & 2.0 & 3.880 \\
\hline $\mathrm{Pd}_{5} \mathrm{Fe}_{1}-\mathrm{NL}$ & $\mathrm{Pd}_{4.92} \mathrm{Fe}_{1}$ & - & - & - & 2.3 & 3.885 \\
\hline
\end{tabular}

The XRD patterns of the $\mathrm{Pd}_{\mathrm{x}} \mathrm{Fe}_{\mathrm{y}}-\mathrm{NL} / \mathrm{C}$ and $\mathrm{Pd} / \mathrm{C}$ catalysts are shown in Fig.4.2 (a). Both $\mathrm{Pd} / \mathrm{C}$ and $\mathrm{Pd}_{\mathrm{x}} \mathrm{Fe}_{\mathrm{y}}-\mathrm{NL} / \mathrm{C}$ catalysts displayed a typical face-centered cubic (fcc) XRD pattern. However, it is observed that all of the diffraction peaks for each of the $\mathrm{Pd}_{\mathrm{x}} \mathrm{Fe}_{\mathrm{y}^{-}}$ NL/C catalysts were slightly shifted to a higher $2 \theta$ (Fig.4.2 (b).), indicating that some Fe atoms may substitute in the Pd lattice, forming an alloy. No obvious diffraction peaks for $\mathrm{Fe}, \mathrm{Fe}_{2} \mathrm{O}_{3}$, or other $\mathrm{Fe}$ oxides were observed in the XRD data of the $\mathrm{Pd}_{\mathrm{x}} \mathrm{Fe}_{\mathrm{y}}-\mathrm{NL} / \mathrm{C}$ catalysts, which suggests that most of the Fe (primarily associated with the Fe sheets, described in detail in the following sections) was amorphous in nature. The average Pd particle size obtained from the $\mathrm{Pd}$ (220) peak using the Debye-Scherrer formula (equation $2-1$ ) is $4.2 \mathrm{~nm}$, while the broad $\mathrm{Pd}$ diffraction peaks associated with the $\mathrm{Pd}_{\mathrm{x}} \mathrm{Fe}_{\mathrm{y}}-\mathrm{NLs} / \mathrm{C}$ (compared to $\mathrm{Pd} / \mathrm{C}$ ) indicate the $\mathrm{Pd}_{\mathrm{x}} \mathrm{Fe}_{\mathrm{y}}-\mathrm{NWs}$ have smaller diameters. 

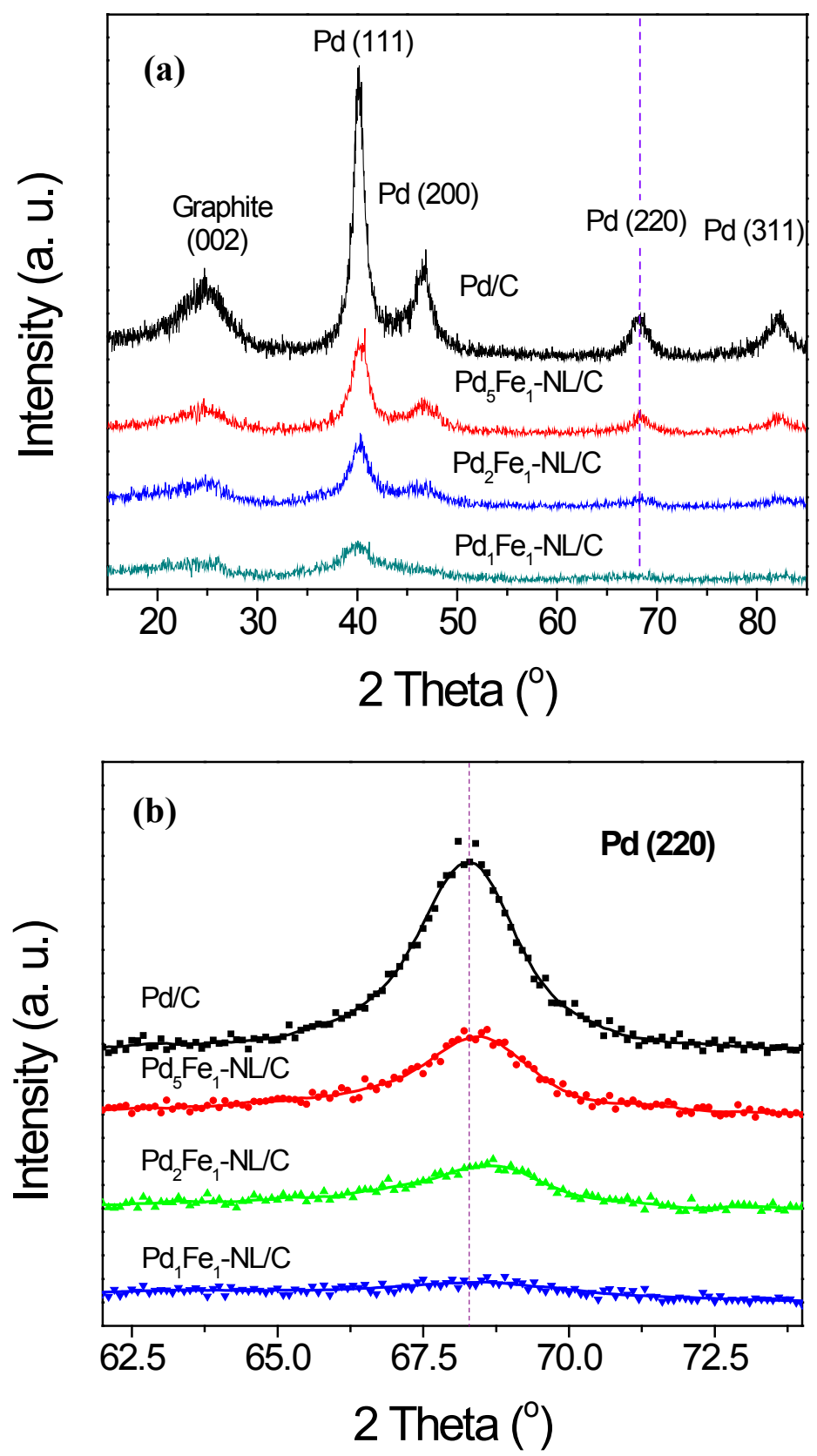

Fig. 4.2 (a) XRD patterns of $\mathrm{Pd} / \mathrm{C}$ and $\mathrm{Pd}_{\mathrm{x}} \mathrm{Fe}_{\mathrm{y}}-\mathrm{NL} / \mathrm{C}$ samples with different $\mathrm{PdFe}$ compositions produced by the solution-phase reduction method, and (b) detailed $\mathrm{Pt}$ (220) diffraction peaks.

Fig. 4.3 shows TEM images of $\mathrm{Pd}_{x} \mathrm{Fe}_{\mathrm{y}}$-NLs with different $\mathrm{Pd}-\mathrm{Fe}$ atomic ratios of 1:1, 2:1, and 5:1. It is clearly observed that the amount of the sheet-like material in the NLs was reduced with smaller amounts of Fe injected into the synthesis system, suggesting that the sheets are Fe-based phases and the Fe concentration (in the synthesis system) controls the 
morphology of the as-prepared nanowires embedded in the sheets. As shown in Fig. 4.3 (a) and (b), a higher Fe concentration results in long, thin and straight Pd-NWs with a size of $\sim 100 \mathrm{~nm} \times 1.8 \mathrm{~nm}$ (length $\times$ diameter). As the Fe concentration is decreased by half, the size of Pd-NWs is $\sim 60 \mathrm{~nm} \times 2.0 \mathrm{~nm}$, as shown in Fig. 4.3 (c) and (d). A further decrease of the Fe content to one fifths leads to shorter and slightly wider nanorods with a size of $\sim 30 \mathrm{~nm} \times 2.3 \mathrm{~nm}$, as shown in Fig. 4.3 (e) and (f). Therefore, decreasing the Fe content results in the formation of 1-D Pd nanostructures with shorter lengths and larger diameters. A typical HR-TEM image of the Pd-NWs in the $\mathrm{Pd}_{1} \mathrm{Fe}_{1}-\mathrm{NL}$ sample is shown in Fig. 4.3 (g), which clearly shows that the side surfaces of the Pd-NWs are predominantly Pd (111) planes, while (110) and (100) planes are at the ends and tips of the NWs.
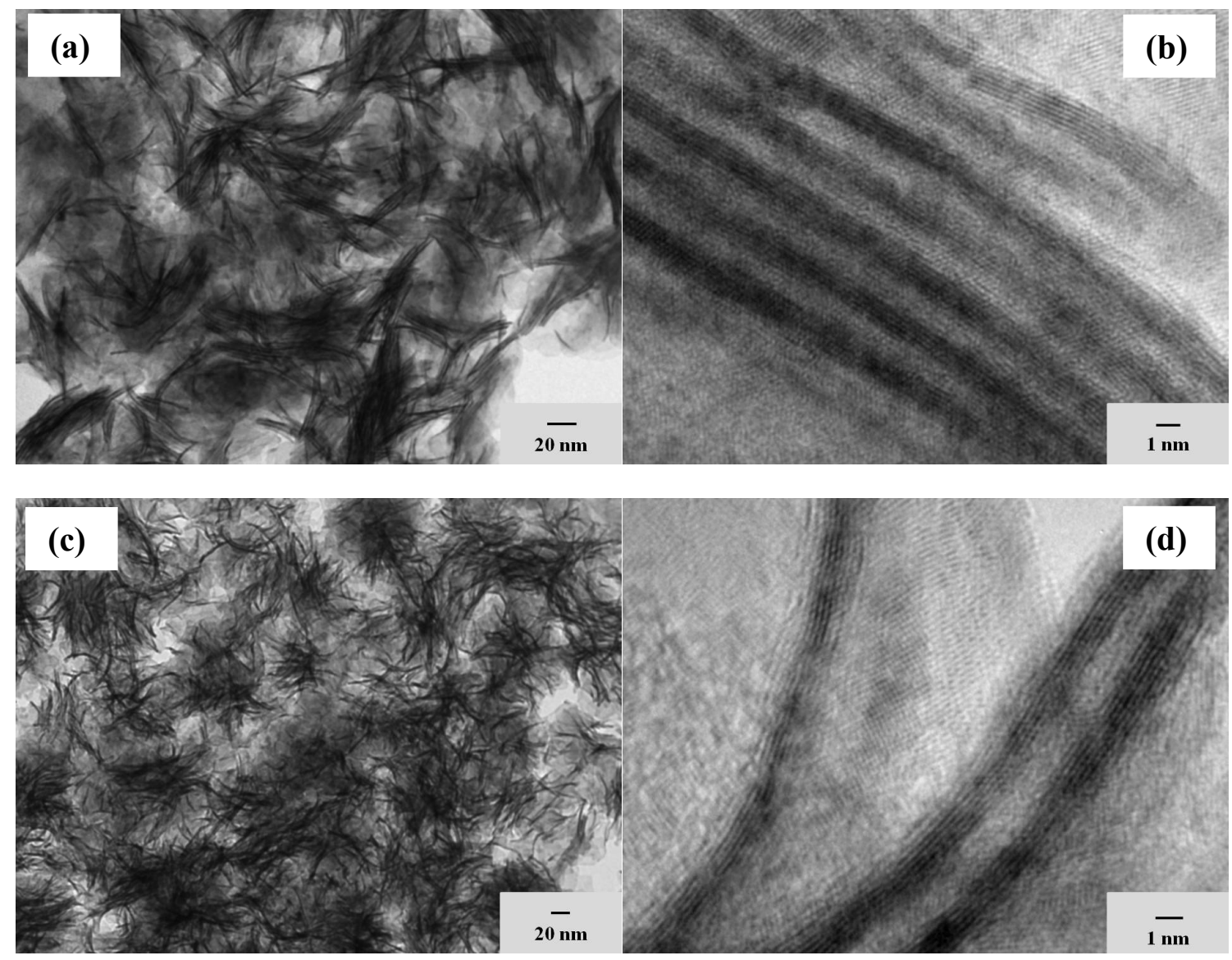

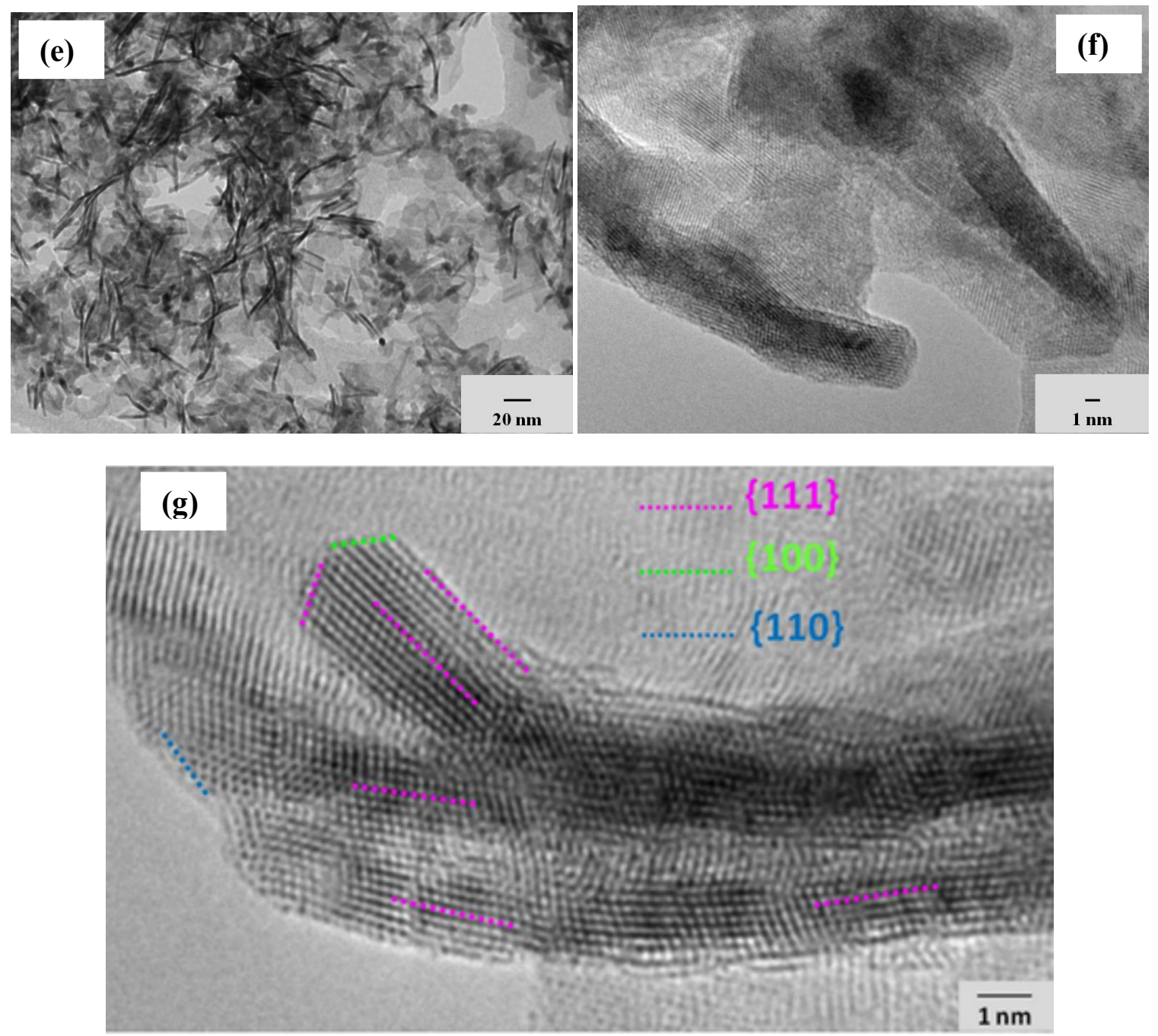

Fig. 4.3 TEM images of the PdFe-NLs, (a,b) $\mathrm{Pd}_{1} \mathrm{Fe}_{1}$-NLs, (c,d) $\mathrm{Pd}_{2} \mathrm{Fe}_{1}$-NLs, (e,f) $\mathrm{Pd}_{5} \mathrm{Fe}_{1}-$ NLs, and HRTEM image of $\mathrm{Pd}_{1} \mathrm{Fe}_{1}-\mathrm{NLs}$ (g), showing $\mathrm{Pd}(111)$-rich side and $\mathrm{Pd}(110)$ and (100) on tips and edges.

To avoid nanoleave agglomeration, the $\mathrm{Pd}_{\mathrm{x}} \mathrm{Fe}_{\mathrm{y}}-\mathrm{NLs}$ were deposited on carbon black before acid treatments. The morphology, compositional architecture, and crystalline structure of $\mathrm{Pd}_{\mathrm{x}} \mathrm{Fe}_{\mathrm{y}}-\mathrm{NLs} / \mathrm{C}$ were compared to the as-prepared $\mathrm{Pd}_{\mathrm{x}} \mathrm{Fe}_{\mathrm{y}}-\mathrm{NLs}$. As shown in Fig. 4.4 (a), the $\mathrm{Pd}_{1} \mathrm{Fe}_{1}-\mathrm{NLs}$ were well attached to the carbon black support. The HREDS elemental mappings shown in Fig. 4.4 (b) - (d) differentiate the Pd-rich-NW veins ( $\mathrm{Pd}$ shown in green) and the Fe-rich-sheet blades (Fe shown in red) of the nanoleaves. It is noted that there is an overlap between the Pd and Fe, indicating that a small amount of $\mathrm{Pd}$ is in the Fe-rich sheets and that the Fe-rich sheets encapsulate the Pd-NWs. The 
encapsulation of the NWs by the Fe-rich sheets is also evident from the HAADF-STEM and TEM images in Fig. 4.4 (e) and (f), where the thin Fe-rich layers encapsulate the PdNWs. In addition, a direct comparison between simultaneously acquired HAADF-STEM (Fig. 4.4 (g)) and SEM (Fig. 4.3 (h)) images clearly show this encapsulation effect, where the HAADF-STEM image predominantly emphasizes the high atomic number NWs within the NL structure and the SEM image shows the topography (sheet-like encapsulation) of the NL.

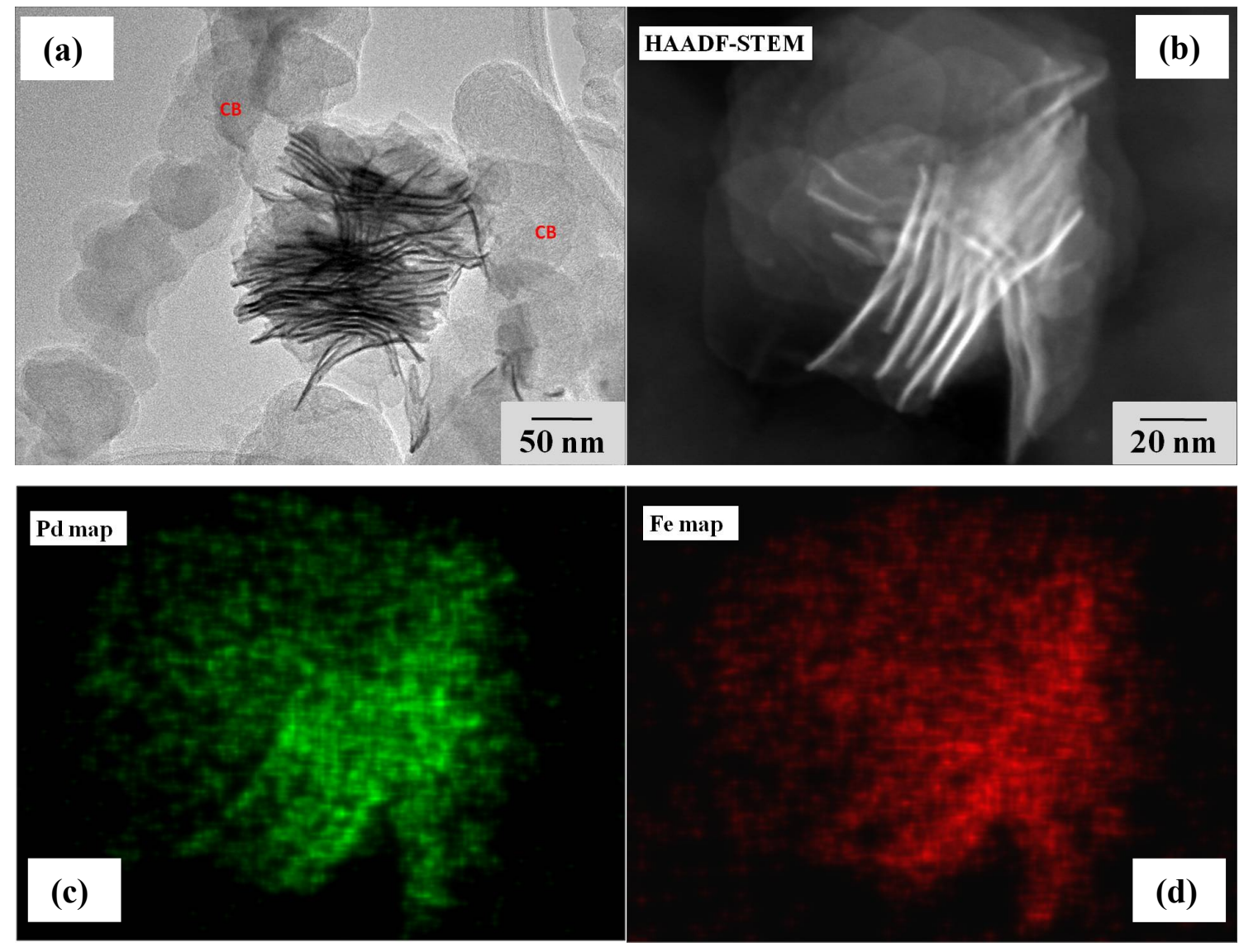



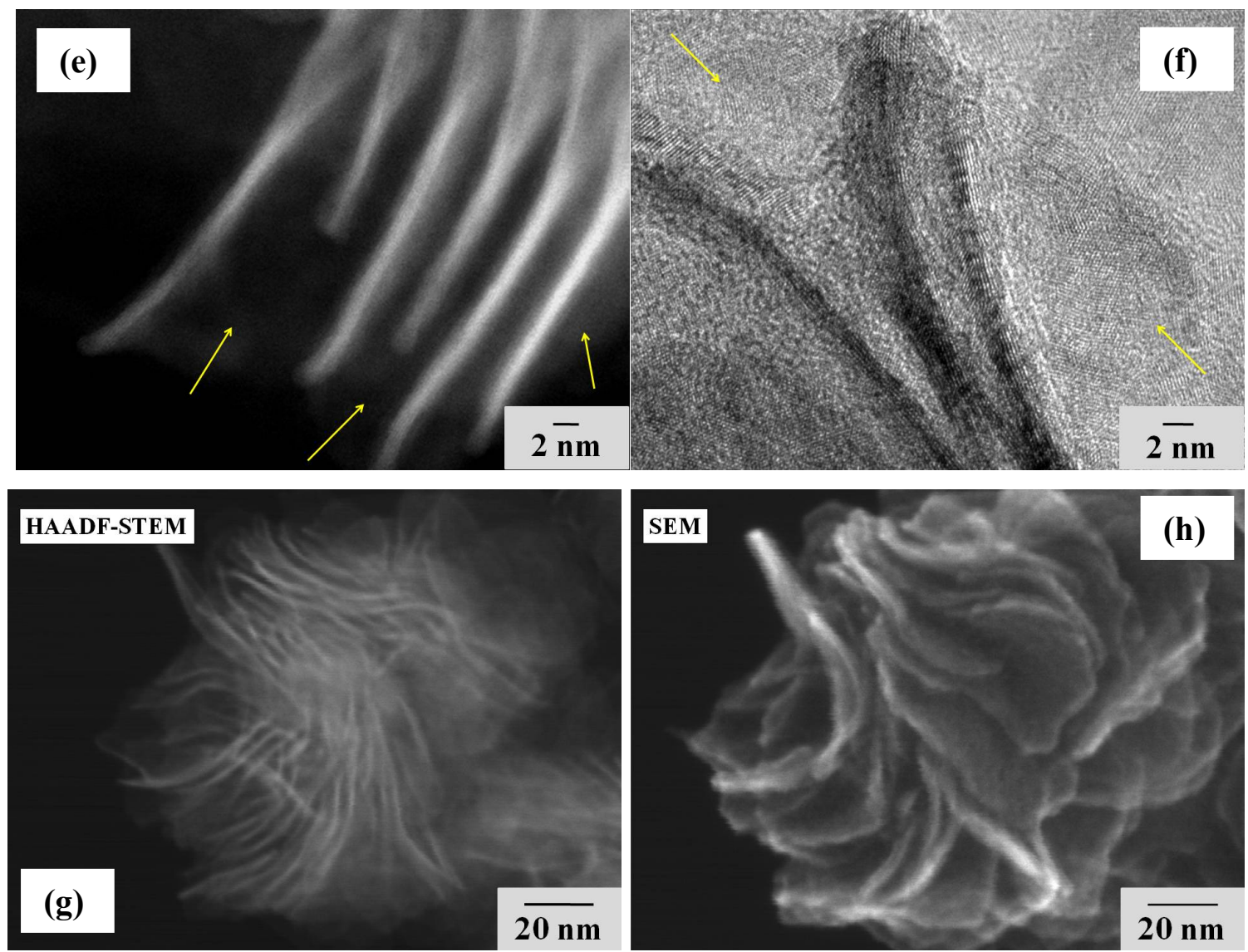

Fig. 4.4 Morphology of $\mathrm{Pd}_{1} \mathrm{Fe}_{1}-\mathrm{NLs} / \mathrm{C}$ : (a) TEM image, (b) HAADF-STEM image, (c) and (d) elemental mapping (HR-EDS); (e) and (f) HAADF-STEM and TEM images showing NWs encapsulated by Fe-rich sheets (designated by yellow arrows), (g) and (h) HAADF-STEM and SEM images showing the encapsulation of NWs in $\mathrm{Pd}_{1} \mathrm{Fe}_{1}-\mathrm{NL}$ and its topography.

The XPS spectra for the $\mathrm{Pd}_{1} \mathrm{Fe}_{1}-\mathrm{NL} / \mathrm{C}$ sample are shown in Fig. 4.5. The large-range XPS survey clearly shows $\mathrm{Pd}, \mathrm{Fe}$, and $\mathrm{C}$, as well as trace amounts of $\mathrm{S}$ and $\mathrm{N}$ that originate from the carbon black and absorbed OAm, respectively. Due to the fact that the asprepared NLs were exposed to air, $\mathrm{O}$ was also detected. The atomic ratio of $\mathrm{Pd}$ and $\mathrm{Fe}$, which was calculated based on narrow scans at $329-347 \mathrm{eV}$ and $700-740 \mathrm{eV}$, is close to $2: 1$. It is interesting to observe that the surface atomic ratio of $\mathrm{Pd}$ to $\mathrm{Fe}$ determined from XPS is twice that of the bulk composition obtained from ICP-AES (Pd:Fe = 0.98:1). As XPS measures the top-most several nanometers of material, the difference of atomic ratios from XPS and ICP are consistent with a higher concentration of $\mathrm{Pd}$ on the $\mathrm{Fe}$ substrates in the NLs. Combining the evidence for encapsulation of Pd-NWs by Fe-rich 
sheets from the HAADF-STEM and TEM analysis, with the Pd-Fe composition from the XPS and ICP-AES results, we can reveal that the $\mathrm{Pd}_{\mathrm{x}} \mathrm{Fe}_{\mathrm{y}}-\mathrm{NLs}$ has a unique structure with Fe-rich sheets as a substrate and Fe-covered Pd-NWs on the surface. Since Pd-NWs are only covered by a thin Fe layer, XPS analysis could detect and count both Pd and Fe in the analysis area.
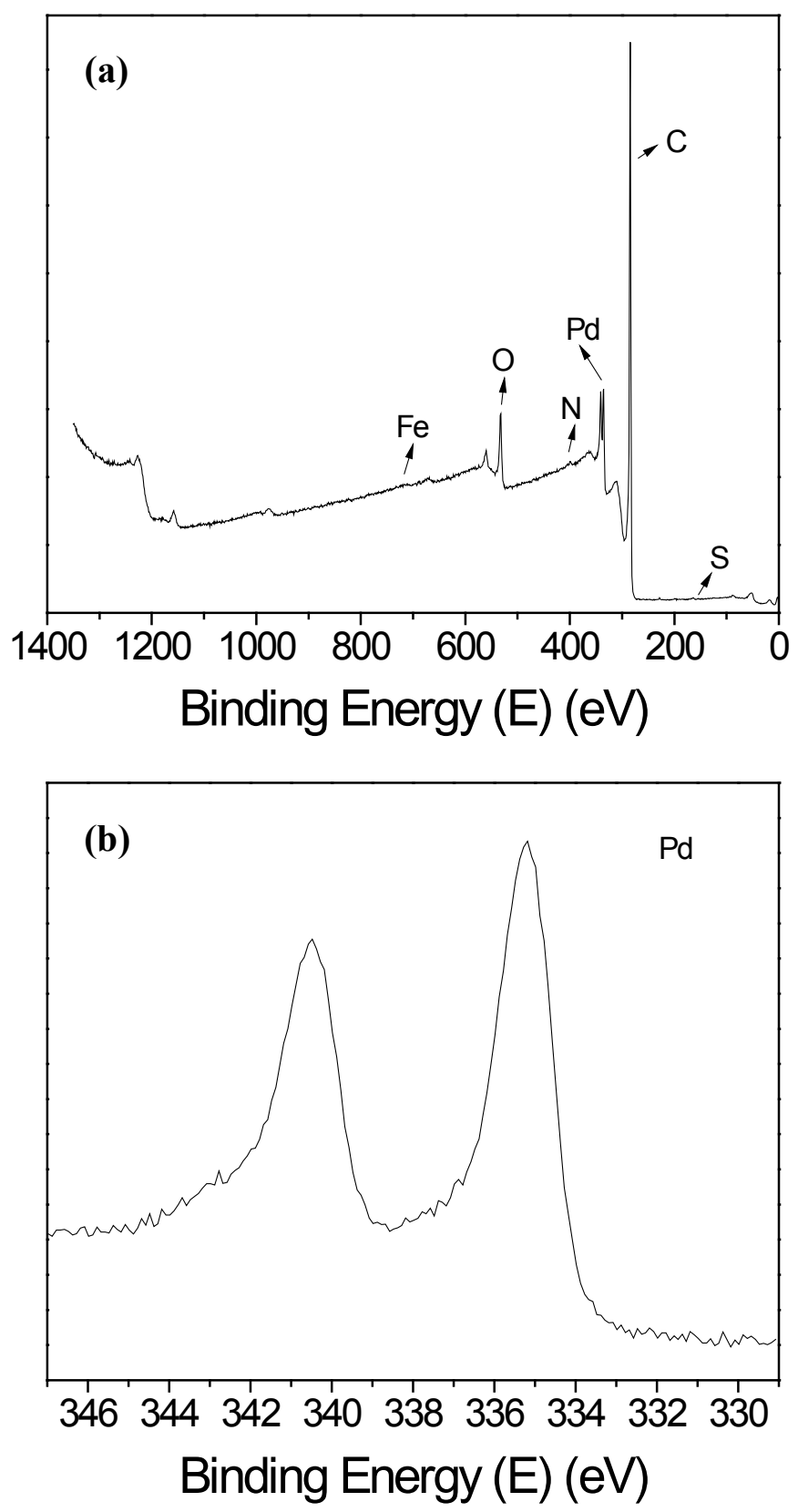


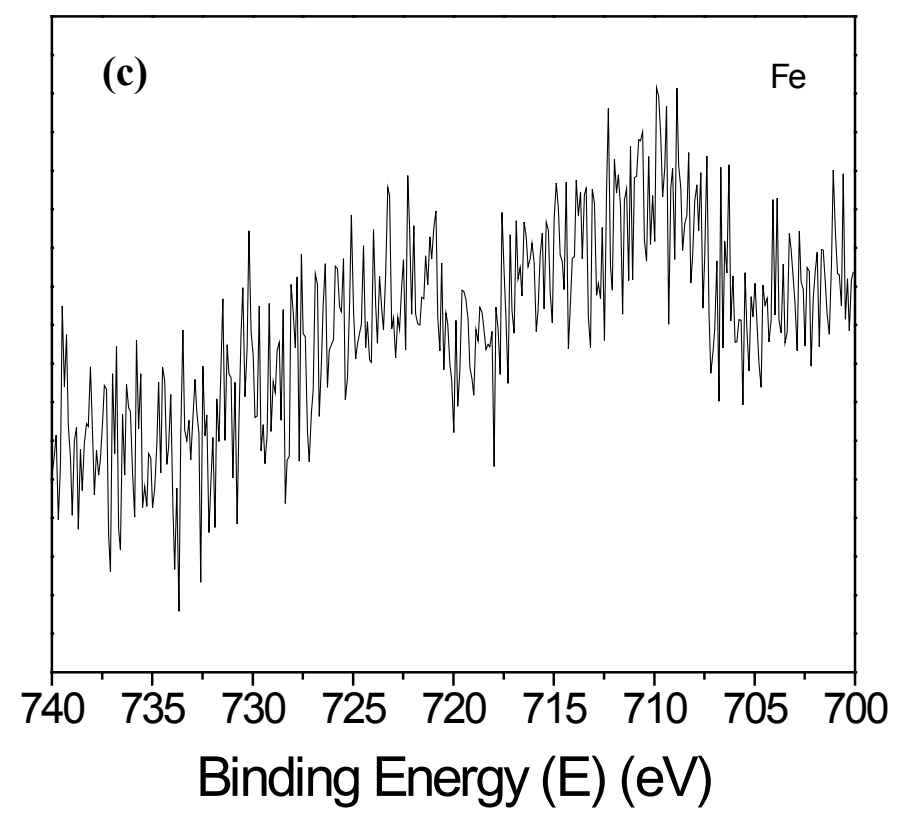

Fig. 4.5 XPS spectrum of $\mathrm{Pd}_{1}-\mathrm{NL} / \mathrm{C}$ (a) Survey scan, (b) Narrow scan of Fe, (c) Narrow scan of Pd

Based on the characterization results presented, a mechanism is proposed for formation of the PdFe nanoleaves. $\mathrm{Pd}(\mathrm{acac})_{2}$ is dissolved in $\mathrm{OAm}$ with a quick injection of $\mathrm{Fe}(\mathrm{CO})_{5}$ at $105^{\circ} \mathrm{C}$, which facilitates fast $\mathrm{Pd}$ nucleation and produces a large density of Pd nuclei. This process can be evidenced by an immediate color change from bright yellow to dark black. The optimized temperature promotes a balance between the generation of new Pd atoms and the growth of $\mathrm{Pd}$ atoms on existing Pd nuclei. The OAm in the system works as solvent, surfactant, and a reducing agent. ${ }^{94,152}$ It is demonstrated to facilitate the generation of $\mathrm{Pd}$ (111) surface plane in previous published work, ${ }^{152}$ indicating that OAm will selectively bond on Pd (111) facets, leading to a higher surfactant density on these surfaces. Therefore, Pd atoms are more easily attached or added on the (100) and (110) facets at the NW ends, which have less surfactants, resulting in the elongation of the nanowire parallel to the (111) surface facets. $\mathrm{Fe}(\mathrm{CO})_{5}$ injected into the system also facilitates the formation of uniformed Pd-NWs. Without $\mathrm{Fe}(\mathrm{CO})_{5}$, the main products in pure OAm system are Pd nanoparticles. ${ }^{152}$ In the present study, it is also observed that short rods and nanoparticles co-exist in the $\mathrm{Pd}_{5} \mathrm{Fe}_{1}-\mathrm{NL}$ sample. Unlike Pt, which can form a PtFe alloy NW through a spin-orbit coupling and hybridization between $\mathrm{Fe} 3 \mathrm{~d}$ and $\mathrm{Pt}$ 5d, ${ }^{94,97} \mathrm{Pd}$ seems more likely to form NWs with very small amounts of Fe dissolved in it, 
which is evidenced by slight shifts observed for the Pd (220) peak (less formation of a PdFe alloy structure) in Fig. 4.2 and the HR-EDS elemental mapping in Fig. 4.4. Considering the fact that $\mathrm{OAm}$ is not a strong ligand for $\mathrm{Fe},{ }^{153} \mathrm{Fe}$ atoms prefer to grow as Fe-rich sheets, which is supported by the fact that less Fe-rich sheets are observed with decreasing Fe concentration, as shown in Fig. 4.3 (a), (c), and (e). For the Pd fcc structure, the surface energy of low-index crystallographic facets in vacuum follows a sequence of $\gamma(111)<\gamma(100)<\gamma(110)$, Pd atoms are expected to nucleate and grow into cuboctohedral or quasi-spherical seeds with a mixture of (111) and (100) facets in order to minimize the total surface energy. ${ }^{59,154,155}$ Under the synthesis conditions describe herein, the Pd-NWs in PdFe-NLs were enveloped in Fe-rich sheets, which may effectively prohibit the deformation or breakage of the Pd-NWs to convert into Pd nanoparticles with a surface energy balance between (111) and (100) facets. This further suggests that thin and long Pd nanowires have an ability of maintaining a large portion of surface Pd (111) plane, which cannot be achieved by Pd nanoparticles with a cuboctohedron shape. When the Fe amount decreased to one half of that of Pd, not enough Fe sheets were formed to protect the long and straight Pd-NWs from deformation, leading to the formation of curved nanowires, as shown in Fig. 4.3 (c). Further reduction in the Fe amount would likely lead to reduced Fe-rich sheet formation, and result in the enhanced likelihood of breakage and rearrangement of Pd-NWs, which is evidenced by the formation of shorter and thicker Pd nanorods, as shown in Fig. 4.3 (e).

To further clarify the proposed nanoleaves growth mechanism, we investigated the effects of injecting $\mathrm{Fe}(\mathrm{CO})_{5}$ on the formation of the $\mathrm{Pd}_{1} \mathrm{Fe}_{1}-\mathrm{NLs}$. For these experiments, a sample of $\mathrm{Pd}_{1} \mathrm{Fe}_{1}$-NL-B was prepared by mixing $\mathrm{Pd}(\mathrm{acac})_{2}$ and $\mathrm{Fe}(\mathrm{CO})_{5}$ at $60^{\circ} \mathrm{C}$. A sample of PdFe-NL-C was produced by the injection of $\mathrm{Fe}(\mathrm{CO})_{5}$ after reducing $\mathrm{Pd}(\mathrm{acac})_{2}$ at $105^{\circ} \mathrm{C}$ for 20 minute. The TEM images of $\mathrm{Pd}_{1} \mathrm{Fe}_{1}-\mathrm{NL}-\mathrm{B}$ and $\mathrm{Pd}_{1} \mathrm{Fe}_{1}-\mathrm{NL}-\mathrm{C}$ are shown in Fig. 4.6. Although Pd-NWs with small diameters of $2-3 \mathrm{~nm}$ are produced for each synthesis condition, the homogeneity of these two samples are not well controlled compared to $\mathrm{Pd}_{1} \mathrm{Fe}_{1}-\mathrm{NL}$. Lowering the injection temperature of $\mathrm{Fe}(\mathrm{CO})_{5}$ restricted the reduction rate of $\operatorname{Pd}(\mathrm{acac})_{2}$, thus leading to a slow and continuous nucleation process, which resulted in a broader length distribution of Pd-NWs (Fig. 4.6 (a) and (b)). On the 
other hand, immediately increasing the temperature right after the quick injection of $\mathrm{Fe}(\mathrm{CO})_{5}$ without further aging will accelerate the decomposition of $\mathrm{Fe}(\mathrm{CO})_{5}$. Therefore, serious PdFe-NRs entanglements/aggregations are observed in $\mathrm{Pd}_{1} \mathrm{Fe}_{1}-\mathrm{NL}-\mathrm{C}$ sample (Fig. 4.6 (c) and (d)).

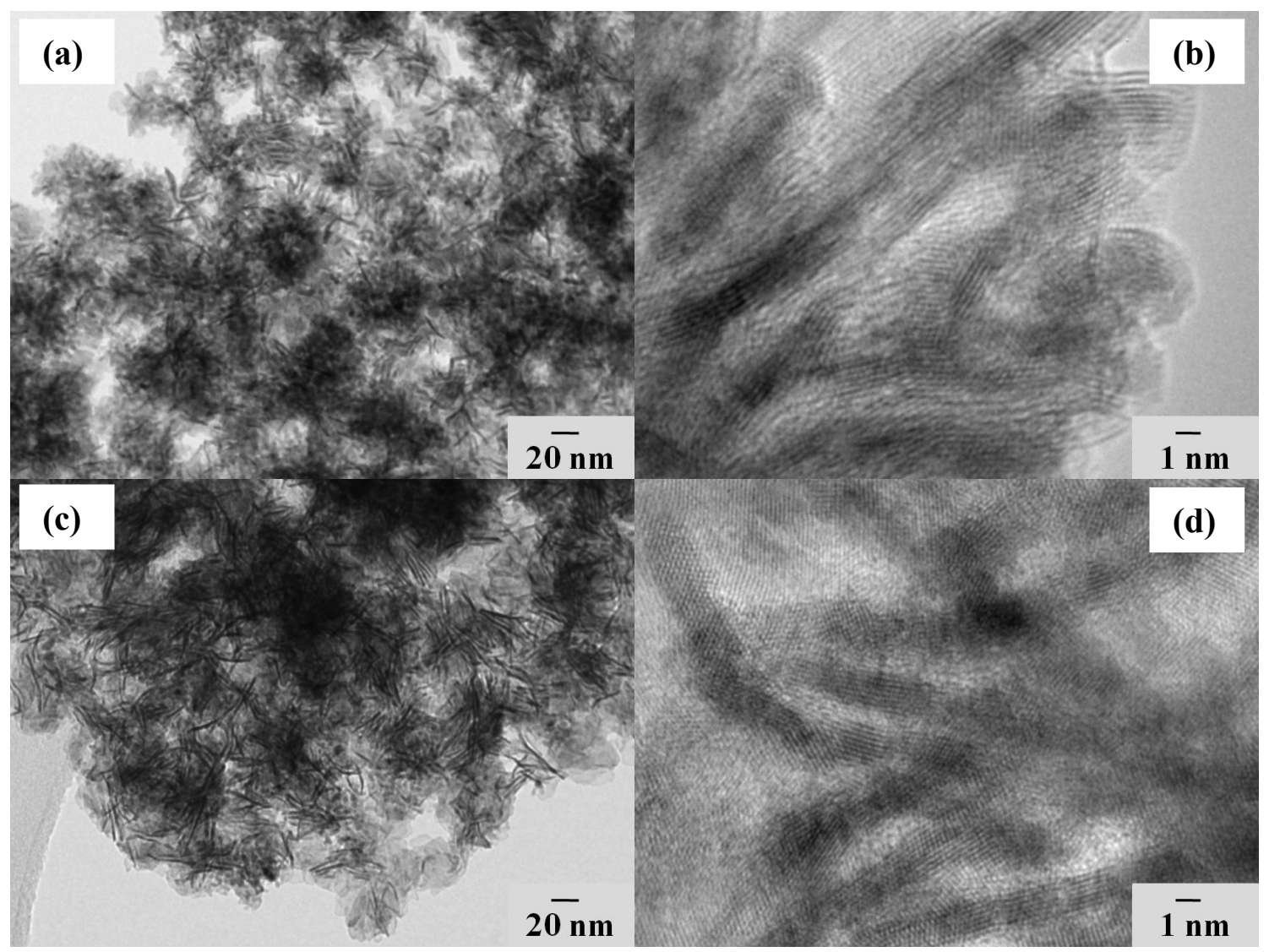

Fig. 4.6 TEM images of the PdFe-NWs prepared with different conditions: (a, b) injection of $\mathrm{Fe}(\mathrm{CO})_{5}$ at $60^{\circ} \mathrm{C}$, (c, d) injection of $\mathrm{Fe}(\mathrm{CO})_{5}$ after aging at $105^{\circ} \mathrm{C}$ for $20 \mathrm{~min}$.

Pd-rich NLs can be achieved after the removal of Fe in the PdFe-NLs through an organic acid treatment. After the acid treatment, the structure of the $\mathrm{Pd}_{1}-\mathrm{NL} / \mathrm{C}\left(\mathrm{Pd}_{1} \mathrm{Fe}_{1}-\mathrm{NL} / \mathrm{C}\right.$ after acetic acid treatment) was characterized using SEM, HAAD-S/TEM, and HR-EDS element mapping. The TEM image in Fig. 4.7 (a) clearly shows that after acid leaching, the NW structure is maintained in a NL structure without any observable morphology changes. HR-EDS elemental mappings were obtained to study the effects of acid treatment on the composition of the NL particles, and are shown in Fig. 4.7 (b) - (d). The removal of Fe is clearly shown, with most of the Fe confined to the center of the NL 
structure, while little change was observed for the Pd-NWs. Quantitative EDS analysis showed the overall $\mathrm{Pd}_{1}-\mathrm{NL}$ has an atomic ratio of $\mathrm{Pd}$ : $\mathrm{Fe}=16: 1$, which is in good agreement with the results of ICP-AES analysis $(\mathrm{Pd}: \mathrm{Fe}=16.8: 1)$. Since the ratio of $\mathrm{Pd}$ : Fe in the initial $\mathrm{Pd}_{1} \mathrm{Fe}_{1}-\mathrm{NL}$ is very close to $1: 1$, this indicates that a significant amount of the Fe phase has been removed and that nearly pure Pd-NWs remain in the NLs.

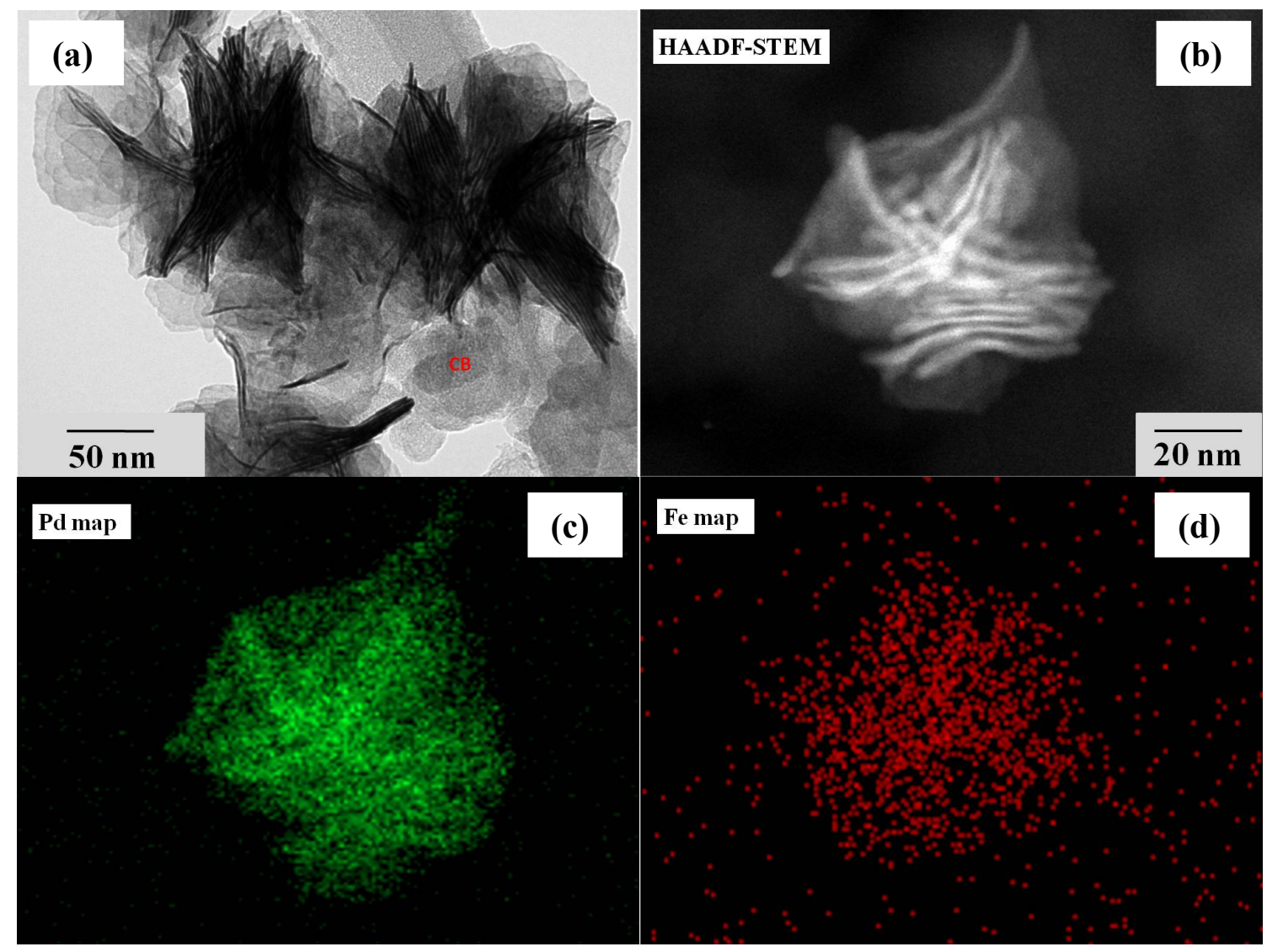

Fig. 4.7 Morphology of $\mathrm{Pd}_{1}-\mathrm{NL} / \mathrm{C}\left(\mathrm{Pd}_{1} \mathrm{Fe}_{1}-\mathrm{NL} / \mathrm{C}\right.$ after acid treatment): (a) TEM image; (b) HAADF-STEM image, (c) and (d) elemental mapping (HR-EDS).

XPS characterization results for the acid-leached $\mathrm{Pd}_{1}-\mathrm{NL}$ sample are shown in Fig. 4.8 and confirm the significant removal of $\mathrm{Fe}$ from the $\mathrm{Pd}_{1} \mathrm{Fe}_{1}-\mathrm{NL} / \mathrm{C}$. The atomic ratio of Pd:Fe measured by XPS is 17.3: 1, which is consistent with the ratio determined by both EDS and ICP-AES. The XPS analysis also shows a sharp decrease in $\mathrm{N}$ as a result of the acid treatment, from $1.6 \%$ to $0.4 \%$, which could be attributed to the removal of surfactant OAm through the acid-leaching procedure. However, because of the adsorption of $\mathrm{N}_{2}$ 
from the air, the $\mathrm{N}$ concentration determined by XPS cannot be used to determine the actual amount of residual surfactants.

The amounts of surfactants removed were determined by comparing the thermal gravimetric analysis (TGA) curves on $\mathrm{Pd}_{1} \mathrm{Fe}_{1}-\mathrm{NL} / \mathrm{C}$ and $\mathrm{Pd}_{1}-\mathrm{NL} / \mathrm{C}$, and the results are shown in Fig. 4.9. The first two steps were carried out form R. T. to $500^{\circ} \mathrm{C}$ in inert $\mathrm{N}_{2}$ gas, and the third step is from $500-700^{\circ} \mathrm{C}$ in oxidative air (as shown in Fig. 4.9 inserted). During the first two steps, the weight loss can be mainly attributed to the thermodecomposition of organic surfactants taking into consideration of the good stabilities of $\mathrm{Pd}, \mathrm{Fe}$ metals and carbon black in $\mathrm{N}_{2}$ in the conducted temperature range. Before the acetic acid treatment, the weight loss of $\mathrm{Pd}_{1} \mathrm{Fe}_{1}-\mathrm{NL} / \mathrm{C}$ initiated at around $125^{\circ} \mathrm{C}$ and underwent a total loss of $24 \mathrm{wt} . \%$ at $500^{\circ} \mathrm{C}$. However, after the acetic acid treatment, the weight loss of $\mathrm{Pd}_{1}-\mathrm{NL} / \mathrm{C}$ was only $13 \mathrm{wt} . \%$. The weight loss observed at around $100^{\circ} \mathrm{C}$ for the $\mathrm{Pd}_{1}-\mathrm{NL} / \mathrm{C}$ was assigned to the evaporation of water absorbed into the sample. However, the weight loss (at around $100^{\circ} \mathrm{C}$ ) was not observed on the $\mathrm{Pd}_{1} \mathrm{Fe}_{1}-\mathrm{NL} / \mathrm{C}$, which was probably a result of the hydrophobic nature of OAm that covered the untreated $\mathrm{Pd}_{1} \mathrm{Fe}_{1}-\mathrm{NL}$ and compelled water absorption. The removal of OAm in organic acid is in agreement with prior work from other groups. ${ }^{152,156}$ The removal of OAm may be caused by the reaction between $-\mathrm{COOH}$ in acetic acid and $\mathrm{NH}_{2}-$ in $\mathrm{OAm}$ at an elevated temperature, i.e. at $70^{\circ} \mathrm{C}$ in our study. The huge loss from $500-600^{\circ} \mathrm{C}$ is the rapid oxidation of carbon support in air. Due to the formation of metal oxides at higher temperature, a gradual weight increasing and a small step afterward exists on $\mathrm{Pd}_{1}-\mathrm{NL} / \mathrm{C}$ in step 3, which are attribute to the oxidation of $\mathrm{Pd}$ and the decomposition of $\mathrm{PdO}$ to $\mathrm{Pd}^{0}$, respectively. ${ }^{157}$ As the encapsulation of Pd-NWs by Fe-rich sheets, this thermodecomposition peak of $\mathrm{PdO}$ vanished on $\mathrm{Pd}_{1} \mathrm{Fe}_{1}-\mathrm{NL} / \mathrm{C}$. As the carbon black will be oxidized to $\mathrm{CO}_{2}$ after TGA, the weight of residues can be used to estimate the PdFe metal loading. After the acid treatment, the metal loadings of the $\mathrm{Pd}_{1}-\mathrm{NL} / \mathrm{C}$ and $\mathrm{Pd}_{2}-\mathrm{NL} / \mathrm{C}$ determined by TGA were reduced to $16.5 \mathrm{wt} \%$ and $18.9 \mathrm{wt} \%$, respectively. 

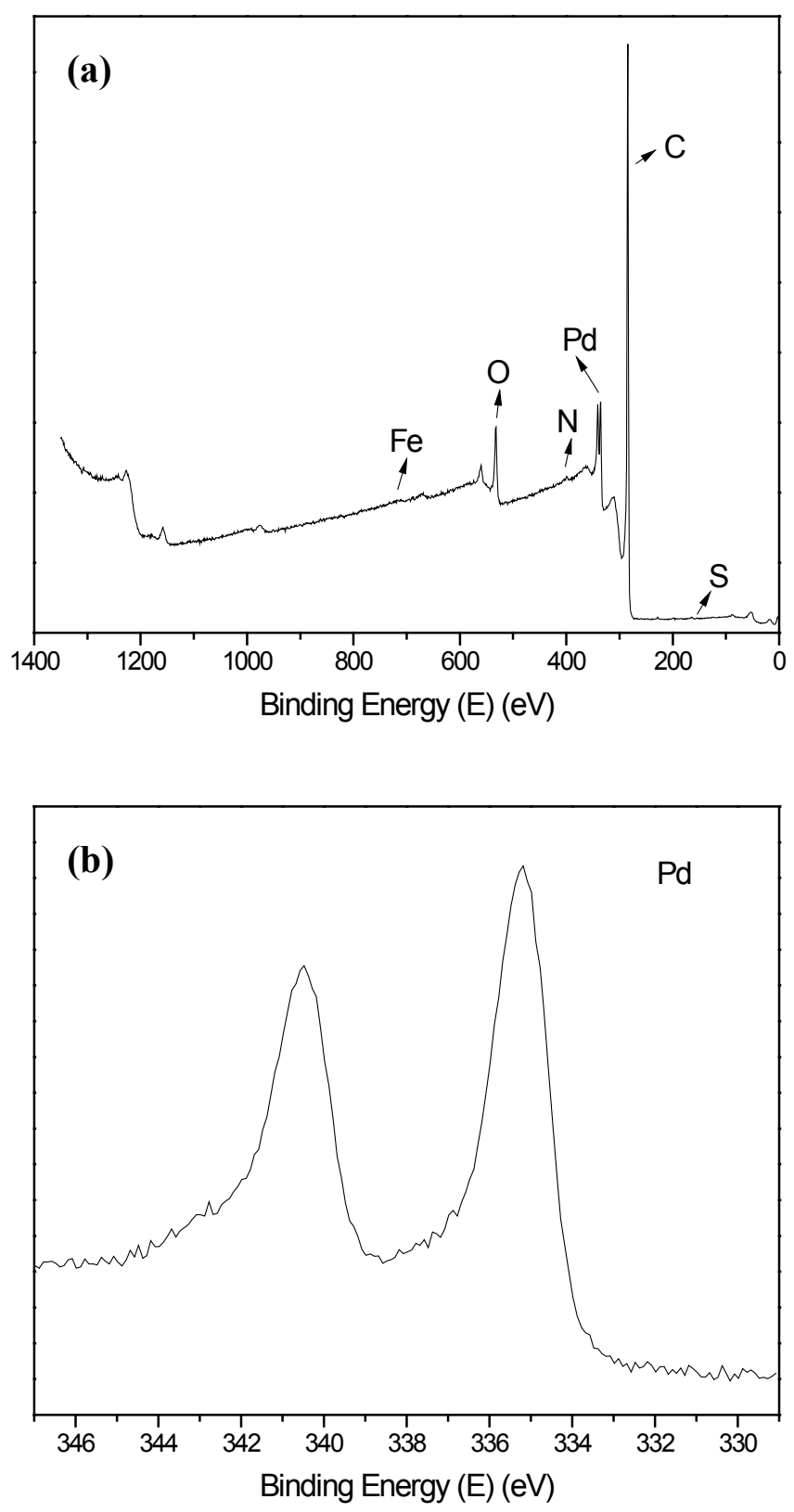


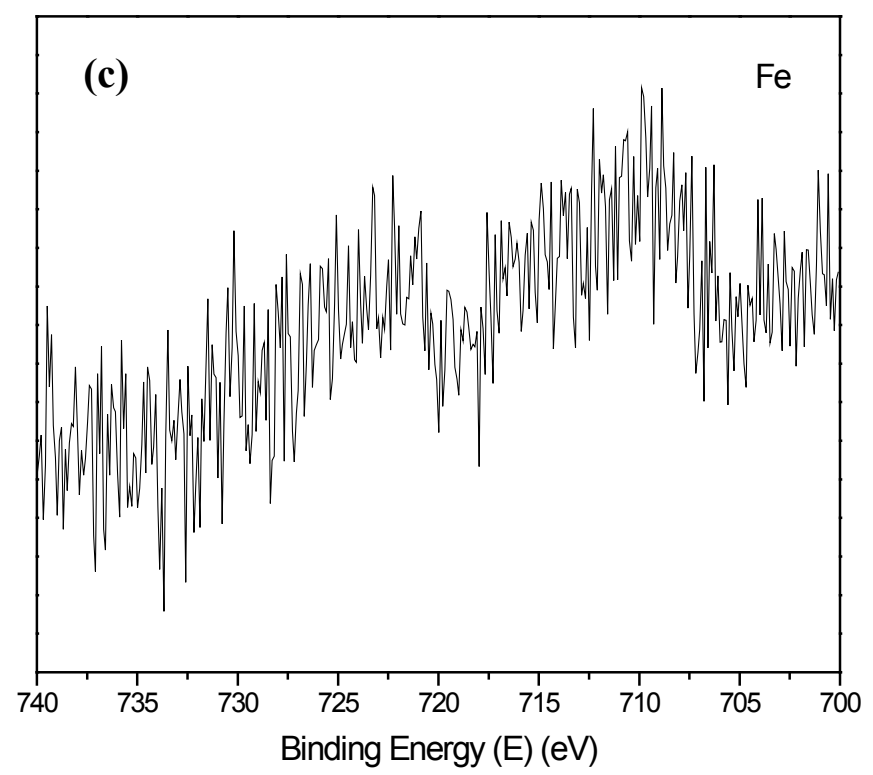

Fig. 4.8 XPS spectra of $\mathrm{Pd}_{1}-\mathrm{NL} / \mathrm{C}$ : (a) survey scan, (b) narrow scan of Fe, (c) narrow scan of $\mathrm{Pd}$.

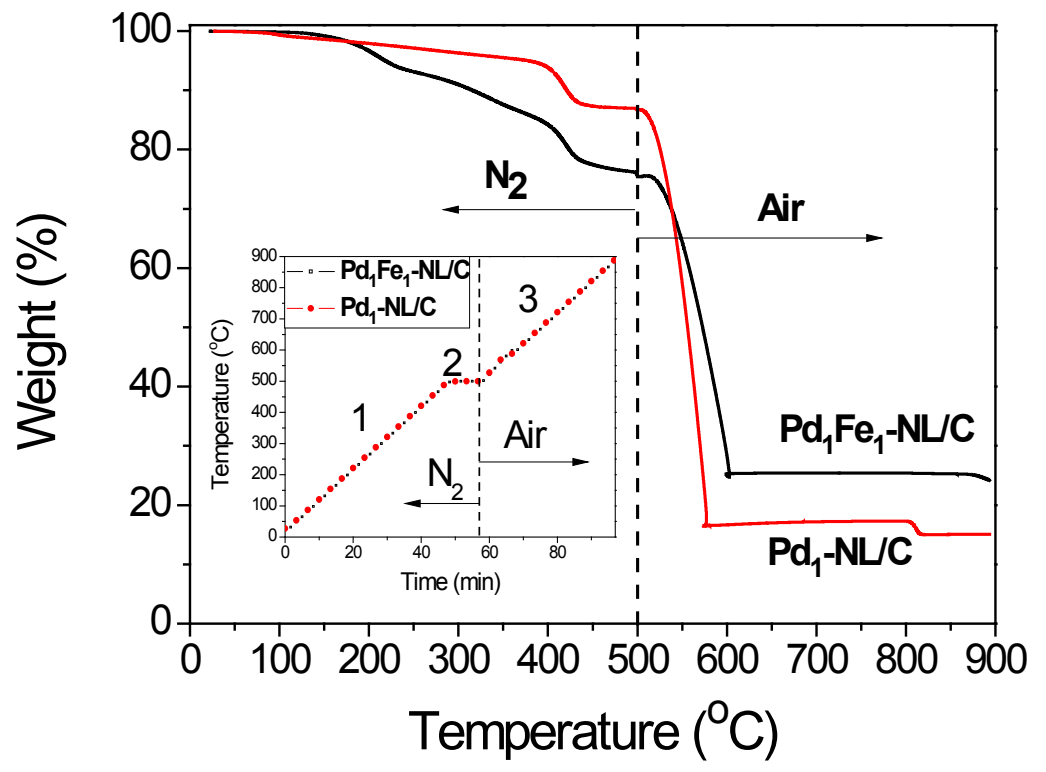

Fig. 4.9 TGA curves and temperature plots (inserted) of $\mathrm{Pd}_{1} \mathrm{Fe}_{1}-\mathrm{NL} / \mathrm{C}$ and $\mathrm{Pd}_{1}-\mathrm{NL} / \mathrm{C}$ $\left(\mathrm{Pd}_{1} \mathrm{Fe}_{1}-\mathrm{NL} / \mathrm{C}\right.$ after acid treatment $)$. 


\subsection{Electro-chemical characterizations}

The electro-catalytic performances were investigated on the $\mathrm{Pd}_{1}-\mathrm{NL} / \mathrm{C}$ and $\mathrm{Pd}_{2}-\mathrm{NL} / \mathrm{C}$ $\left(\mathrm{Pd}_{1} \mathrm{Fe}_{1}-\mathrm{NL} / \mathrm{C}\right.$ and $\mathrm{Pd}_{2} \mathrm{Fe}_{1}-\mathrm{NL} / \mathrm{C}$ after the acid treatment, respectively), and the results were compared with those on the $\mathrm{Pd} / \mathrm{C}$ and commercial $\mathrm{Pt} / \mathrm{C}$ catalysts. Fig. 4.10 shows the cyclic voltammograms of the four catalysts recorded in $\mathrm{N}_{2}$-saturated $1.0 \mathrm{M} \mathrm{NaOH}$ at a sweep rate of $50 \mathrm{mV} \mathrm{s}^{-1}$. Since hydrogen can penetrate into the Pd-based alloy lattices, the ECSAs of the Pd-based catalysts were calculated based on the charge of the reduction region of $\mathrm{PdO} / \mathrm{Pd}$ at around $-0.28 \mathrm{~V}(v s . \mathrm{Hg} / \mathrm{HgO} / 1.0 \mathrm{M} \mathrm{NaOH})$ with double-layer correction, assuming $0.405 \mathrm{mC} \mathrm{cm}^{-2}$ for the reduction of a monolayer $\mathrm{PdO}$ on the catalyst surface. ${ }^{121,122,158}$ The specific ECSAs were 50.9, 51.4 and $35.5 \mathrm{~m}^{2} \mathrm{~g}^{-1}{ }_{\mathrm{Pd}}$ for $\mathrm{Pd}_{1}-\mathrm{NL}, \mathrm{Pd}_{2^{-}}$ $\mathrm{NL}$, and $\mathrm{Pd} / \mathrm{C}$, respectively. For comparison, the ECSA of $\mathrm{Pt} / \mathrm{C}$ was calculated from both the hydrogen desorption peak and PtO reduction peak, these values are 71.8 and $56.9 \mathrm{~m}^{2}$ $\mathrm{g}^{-1} \mathrm{Pt}$, respectively. The $\mathrm{Pd}_{\mathrm{x}}-\mathrm{NLs}$ have larger specific ECSAs, which are attributed to their ultra-thin diameters (around $2 \mathrm{~nm}$ ) of Pd-rich NWs in the Pd-NLs.

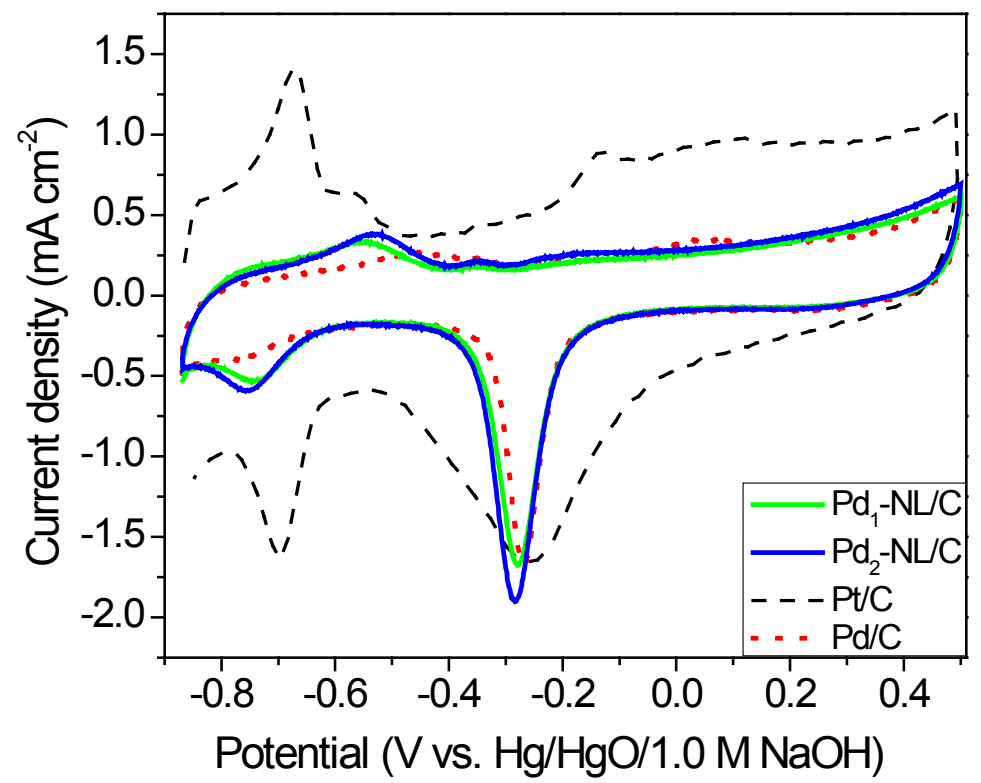

Fig. 4.10 Cyclic voltammograms of commercial $\mathrm{Pt} / \mathrm{C}, \mathrm{Pd} / \mathrm{C}$ (self-prepared by $\mathrm{EG}$ method), $\mathrm{Pd}_{1}-\mathrm{NL} / \mathrm{C}$ and $\mathrm{Pd}_{2}-\mathrm{NL} / \mathrm{C}$ in $1.0 \mathrm{M} \mathrm{NaOH}, \mathrm{N}_{2}$ saturated, $50 \mathrm{mV} / \mathrm{s}$, room temperature. 
The ORR polarization curves for the four catalysts are shown in Fig. 4.11. While the $\mathrm{Pd} / \mathrm{C}$ has a slightly higher ORR activity than the commercial $\mathrm{Pt} / \mathrm{C}$, the $\mathrm{Pd}-\mathrm{NLs}$ show a remarkable improvement in ORR activity with the half-wave potential shifting positively by $\sim 38 \mathrm{mV}$ as compared to $\mathrm{Pt} / \mathrm{C}$. At $0 \mathrm{~V} v s . \mathrm{Hg} / \mathrm{HgO} / 1.0 \mathrm{M} \mathrm{NaOH}$, the mass activity of $\mathrm{Pd}_{1}-\mathrm{NL}$ and $\mathrm{Pd}_{2}-\mathrm{NL}$ are $0.159 \mathrm{~A} \mathrm{mg}^{-1}$ Pd and $0.157 \mathrm{~A} \mathrm{mg}^{-1}$ Pd, respectively, which are 2 times higher than that of $\mathrm{Pd} / \mathrm{C}\left(0.0735 \mathrm{~A} \mathrm{mg}^{-1} \mathrm{Pd}\right)$ and 2.7 times higher than that of $\mathrm{Pt} / \mathrm{C}$ $\left(0.0585 \mathrm{~A} \mathrm{mg}_{\mathrm{Pt}}^{-1}\right)$. Although the TGA curves indicate there are still some surfactants covering Pd-NLs even after the acid treatment, the specific activities of $\mathrm{Pd}_{1}-\mathrm{NLs}$ and $\mathrm{Pd}_{2^{-}}$ NLs at $0 \mathrm{~V}$ vs. $\mathrm{Hg} / \mathrm{HgO} / 1.0 \mathrm{M} \mathrm{NaOH}$ were 312 and $305 \mu \mathrm{A} \mathrm{cm}^{-2}$ Pd, respectively, which are higher than that of $\mathrm{Pd} / \mathrm{C}\left(207 \mu \mathrm{A} / \mathrm{cm}^{-2}{ }_{\mathrm{Pd}}\right)$ and $\mathrm{Pt} / \mathrm{C}\left(103 \mu \mathrm{A} / \mathrm{cm}^{-2}{ }_{\mathrm{Pt}}\right)$. Since the $\mathrm{Pd} / \mathrm{C}$ was prepared by the EG method, its Pd surface is considered clean (very little surfactant effects), the results indicate that small amounts of surfactants (OAm) in the Pd-NLs catalysts will not affect the intrinsic ORR activities in alkaline electrolyte.

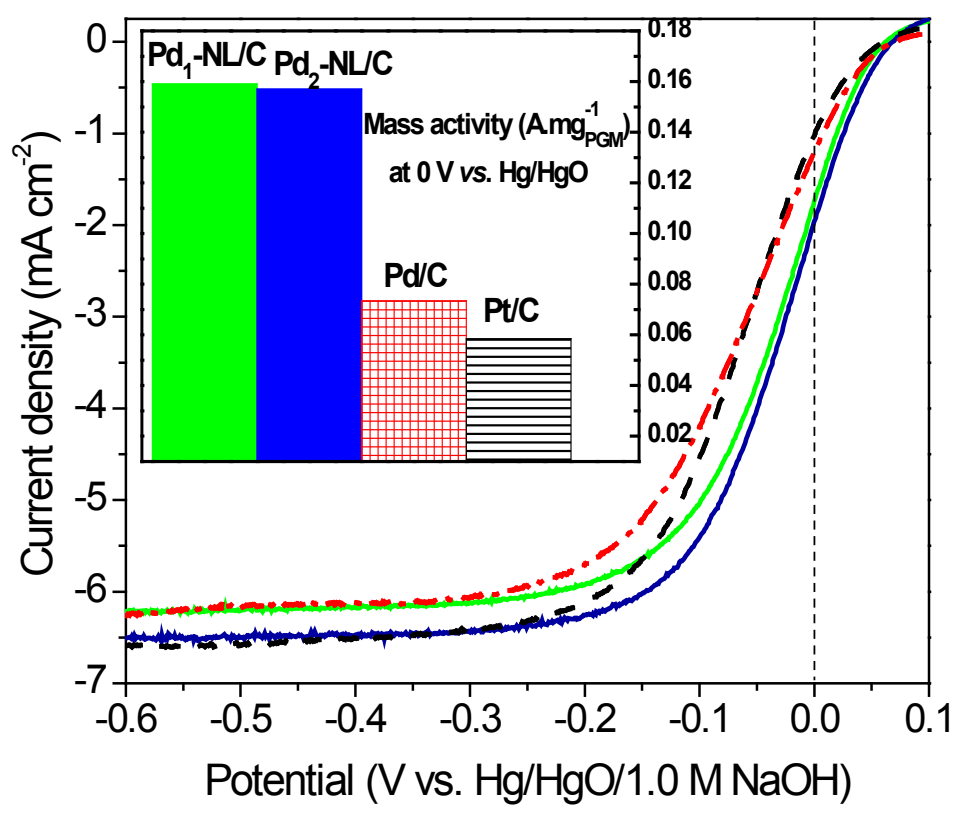

Fig. 4.11 ORR polarization curves of commercial $\mathrm{Pt} / \mathrm{C}, \mathrm{Pd} / \mathrm{C}$ (self-prepared by $\mathrm{EG}$ method), $\mathrm{Pd}_{1}-\mathrm{NL} / \mathrm{C}$ and $\mathrm{Pd}_{2}-\mathrm{NL} / \mathrm{C}$ in $0.1 \mathrm{M} \mathrm{NaOH}, \mathrm{O}_{2}$ bubbling, $10 \mathrm{mV} / \mathrm{s}, 2500 \mathrm{rpm}$, room temperature. 
It has been demonstrated that in acid electrolytes, the intrinsic activity toward ORR on Pd is one magnitude lower than that on $\mathrm{Pt}^{22}$ However, in alkaline electrolytes, Pd is reported to have an ORR activity very close to $\mathrm{Pt}^{119}$ The kinetic current density on $\operatorname{Pd}(111)$ surface plane has been reported only 0.3 times lower than that of $\operatorname{Pt}(111)$ plane at $0.85 \mathrm{~V}$ in $0.1 \mathrm{M} \mathrm{NaOH}$, while the value on commercial $\mathrm{Pd} / \mathrm{C}$ catalyst is also only 0.4 times lower than that of commercial $\mathrm{Pt} / \mathrm{C}$ under the same testing condition. ${ }^{119}$ Jiang, et $\mathrm{al}^{121,122}$ recently reported the apparent ORR activation energies in $0.1 \mathrm{M} \mathrm{KOH}$ for $\mathrm{Pt} / \mathrm{C}$ and $\mathrm{Pd} / \mathrm{C}$ are $48 \mathrm{~kJ} / \mathrm{mol}$ and $40 \mathrm{~kJ} / \mathrm{mol}$, respectively, at an over-potential of $0.3 \mathrm{~V}$, which indicates the ORR kinetics for Pd are similar to Pt. For 0-D nanoparticle catalysts, there typically is an optimum particle size with the highest mass activity, which is a trade-off between surface area, crystalline facets (with different intrinsic activity), and the surface chemical state of Pt and Pd (surface oxidation of Pt and Pd could lead to catalytically inert PtO and $\mathrm{PdO}) .{ }^{121,122}$ As the Pd particle gets smaller than the optimum size, although its surface area increases, the ratio of $\mathrm{Pd}(111)$ to (100) decreases and the surface is more prone to oxidation, therefore, its mass activity drops. The optimum Pd particle size has been found to be $\sim 5.0 \mathrm{~nm}$ for the ORR in an alkaline electrolyte. ${ }^{121} \mathrm{In}$ the present research, the $\mathrm{Pd} / \mathrm{C}$ particle size of $4.2 \mathrm{~nm}$ (which is close to the reported optimum size) shows slightly higher ORR activity than $\mathrm{Pt} / \mathrm{C}$ at $0 \mathrm{~V} \mathrm{Hg} / \mathrm{HgO} / 1.0 \mathrm{M} \mathrm{NaOH}(0.9 \mathrm{~V}$ vs. SHE). When the overpotential increases, the $\mathrm{Pt} / \mathrm{C}$ exhibits a higher current density and reaches a higher limiting current density than $\mathrm{Pd} / \mathrm{C}$. The ORR activity baseline for $\mathrm{Pt} / \mathrm{C}$ and $\mathrm{Pd} / \mathrm{C}$ in the present work is consistent with previous studies.

The much improved ORR activity of Pd-NLs may rise from their unique high surface area, nanoleaves/nanowire structure. Comparing to 0 -D nanoparticles, it has already been reported that 1-D nanowire catalysts, such as Pt-NW and Pt-nanotube (NT) with have an enhanced ORR activity due to the presence of lower surface defects and unique surface electronic properties. ${ }^{57,89}$ However, their large dimensions, i.e. $200 \mathrm{~nm}$ diameter for Pt$\mathrm{NW}^{57}$ and $4-7 \mathrm{~nm}$ wall thickness and $40-50 \mathrm{~nm}$ wall thickness for Pt-NT ${ }^{89}$ resulted in small electro-chemical surface area, thus, limiting their mass activity enhancement. In comparison, the ultra-thin Pd-NWs with a large aspect ratio reported here were uniformly covered by advantageous Pd (111) facet and maintained a large electrochemical surface 
area (i.e. $>50 \mathrm{~m}^{2} / \mathrm{g}$ in this study). In addition, the ultra-thin Pd-NWs were textured in the NLs, which may also enhance the surface oxidation resistance.

\subsection{Conclusion}

In summary, a simple wet chemistry-based solution phase synthesis method has been developed to produce PdFe-nanoleaves. Combined characterizations show that this fantastic structure is Pd-NWs veins assembled with Fe-sheets blades. The side surfaces of the enveloped Pd-NWs are predominantly Pd (111) facet, which was preserved by the Fe sheets and could not be easily restructured. After an acetic acid treatment, the 1-D PdNWs with a diameter around $2 \mathrm{~nm}$ and large surface are of $>50 \mathrm{~m}^{2} \mathrm{~g}^{-1}$ can be exposed on the surface of NLs. The Pd-rich NLs demonstrated high reactivity towards electrocatalytic reduction of oxygen in $0.1 \mathrm{M} \mathrm{NaOH}$ electrolyte: 3.0 times of specific activity and 2.7 times of mass activity higher than a commercial $\mathrm{Pt} / \mathrm{C}$ catalyst (at $0 \mathrm{~V} v s$. $\mathrm{Hg} / \mathrm{HgO} / 1.0 \mathrm{M} \mathrm{NaOH}$ ). The electro-catalytic activity enhancement can be attributed to their unique nanoleaves structure, i.e. more Pd (111) facets, large surface area and more resistance to $\mathrm{Pd}$ oxide formation. The novel PdFe-NLs are a promising new class of cathode catalysts for anion-exchange membrane fuel cells. 


\section{Chapter 5 Pd-Ni electro-catalysts for efficient ethanol oxidation reaction in alkaline electrolyte*}

\subsection{Introduction}

\subsubsection{Background}

Low Temperature $\mathrm{H}_{2}$-fed proton-exchange membrane fuel cells (PEMFCs) have been widely considered as a promising alternative energy technology with high energy conversion efficiency and zero pollutant emissions. However, the production, transport, and storage of $\mathrm{H}_{2}$ are still of great technical challenges. ${ }^{108}$ Comparing to $\mathrm{H}_{2}$ fuel, lignocellulosic biomass-derived ethanol is considered one of the most promising fuel candidates to substitute $\mathrm{H}_{2}$ for supplying future energy needs. ${ }^{160}$ In 2008 , the world bioethanol fuel production stood at more than 17 billion US gallons per year. Blends of gasoline containing $85 \%$ denatured ethanol (E85) have recently appeared at fueling stations in the US, mainly in the Midwest. However, the efficiency of heating engines is confined by Carnot cycle limitations (normally $<35 \%$ ). Direct ethanol fuel cells (DEFCs) are an ideal electro-chemical energy device that can directly convert chemical energy of ethanol into electricity without Carnot limitation. ${ }^{36-38,108,109,164-168}$ Table 5.1 displays the thermodynamic data of $\mathrm{H}_{2-}$ and alcohol-fed fuel cells. Although DEFCs have a lower theoretical potential $(1.14$ vs. $1.23 \mathrm{~V})$ their thermodynamic efficiency of $97 \%$ is higher than that for $\mathrm{H}_{2}$-fuel cells (83\%). ${ }^{169}$ Ethanol has a volumetric energy density of $6.3 \mathrm{kWh}$ $\mathrm{L}^{-1}$, which is higher than hydrogen $\left(2.6 \mathrm{kWh} \mathrm{L}^{-1}\right)$ and methanol $\left(4.8 \mathrm{kWh} \mathrm{L}^{-1}\right)$. Extensive research has been carried out to investigate anode catalysts for proton exchange

\footnotetext{
*The material contained in this chapter was previously published in International Journal of Hydrogen Energy. Reprinted with permission from Journal of Hydrogen Energy 2011; 36, Zhiyong Zhang, Le Xin, Kai Sun, and Wenzhen Li, "Pd-Ni electrocatalysts for efficient ethanol oxidation reaction in alkaline electrolyte", 12686-12697. Copyright 2011 International Association for Hydrogen Energy.
} 
membrane direct ethanol fuel cells (PEM-DEFCs). ${ }^{38,109}$ It has been demonstrated that PtSn-based catalysts are the best among Pt-M (M=Ru, Rh, Sn, W, etc) for ethanol oxidation in acid electrolyte. ${ }^{36,37,165}$ Unfortunately, it was also found that in acid electrolyte, the kinetics of EOR remains sluggish (low activity) and the majority product of EOR is acetic acid $\left(\mathrm{CH}_{3} \mathrm{COOH}\right)$ not $\mathrm{CO}_{2}$ (low catalyst selectivity) even on very expensive PtSn-based catalysts. ${ }^{167,168}$ In addition, expensive Pt-based catalysts are required for a long operation life-time in an acid electrolyte. ${ }^{108}$ The high over-potential of oxygen reduction reaction (ORR) - over $200 \mathrm{mV}$ at the most active Pt surface at the cathode is another long-standing scientific issue to overcome to achieve wide application of PEM-DEFCs. ${ }^{78,105,106,170}$

Recently, some novel high performance solid anion-exchange membranes (AEMs) have been developed, which make alkaline fuel cells more attractive and realistic. ${ }^{109-113,171-176}$ Anion exchange membranes do not contain mobile metal cations, therefore, they address the fatal issues facing conventional alkaline fuel cells: precipitations of carbonate deteriorating electrolyte. ${ }^{109}$ Comparing to the PEM-DEFC, the AEM-DEFC possess enormous advantages: 1) improved kinetics: Slow kinetics of both alcohol oxidation and oxygen reduction reactions can be significantly improved in high $\mathrm{pH}$ media, attributed to enhanced ion transport and facile charge transfer; ${ }^{115,177}$ 2) enhanced life-time: non-Pt catalysts can survive in alkali for a longer time than in acid, due to a less corrosive base environment; ${ }^{15}$ and 3) reduced cost: non-Pt electro-catalysts have demonstrated high activity to ethanol oxidation (i.e. $\mathrm{Pd}, \mathrm{Ni})^{178-184}$ and oxygen reduction reaction (i.e. $\mathrm{Ag}){ }^{172,173}$ attributed to enhanced ion transport and mobile charge transfer in alkaline electrolyte. $^{115}$ 
Table 5.1

Thermodynamic data of Electro-oxidation of various alcohols to fully oxidized products $\left(\mathrm{H}_{2} \mathrm{O}\right.$ and $\left.\mathrm{CO}_{2}\right)$.

\begin{tabular}{cccc}
\hline Fuel & $\mathrm{E}_{0}(\mathrm{~V})$ & $\mathrm{W}_{\mathrm{e}}\left(\mathrm{kW} \mathrm{h} \mathrm{L}^{-1}\right)$ & $\eta(\%)$ \\
\hline Hydrogen $\mathrm{H}_{2}$ & 1.23 & 2.6 (liquid $\left.\mathrm{H}_{2}\right)$ & 83 \\
Methanol $\mathrm{CH}_{3} \mathrm{OH}$ & 1.21 & 4.8 & 97 \\
Ethanol $\mathrm{CH}_{3} \mathrm{CH}_{2} \mathrm{OH}$ & 1.14 & 6.3 & 97 \\
Ethylene glycol $\left(\mathrm{CH}_{2} \mathrm{OH}\right)_{2}$ & 1.22 & 5.9 & 99 \\
Glycerol $\mathrm{HOCH}_{2} \mathrm{CHOHCH}_{2} \mathrm{OH}$ & 1.23 & 6.3 & 98 \\
* $\mathrm{E}_{0}$ : theoretical fuel cell voltage; $\mathrm{W}_{\mathrm{e}}$ : volumetric energy density; $\eta$ : thermodynamic \\
efficiency
\end{tabular}

\subsubsection{Pd-based ethanol electro-oxidation catalysts}

Although Pd is nearly inert to EOR in an acid electrolyte, it has demonstrated competitive EOR activity ${ }^{179,184}$ and slightly better ability to break the C-C bond of ethanol in high $\mathrm{pH}$ media, as compared to Pt-based catalysts. ${ }^{182}$ Comparing to the deficiency of $\mathrm{Pt}$ in the earth's crust $(0.003 \mathrm{ppb})$, the abundance of $\mathrm{Pd}$ is 200 times higher $(0.6 \mathrm{ppb})$. The comparatively low price of $\mathrm{Pd}$ (only $30 \%-40 \%$ compared to $\mathrm{Pt}$ ) makes it attractive as high efficiency anode catalyst for AEM-DEFC.

Numerous publications have concentrated on developing high efficient Pd-based EOR catalysts. A second transition metal, $\mathrm{Sn},{ }^{186} \mathrm{Ni},{ }^{187,188} \mathrm{Ru},{ }^{189,190}$ or $\mathrm{Ag},{ }^{191}$ was chosen to be incorporated with $\mathrm{Pd}$, in order to facilitate the removal of poisonous intermediates. In addition, catalyst supports, including $\mathrm{Ni},{ }^{189,190} \mathrm{Ti}^{192}, \mathrm{TiO}_{2} / \mathrm{C},{ }^{193} \mathrm{Ni}-\mathrm{Zn} / \mathrm{C},{ }^{183} \mathrm{CeO}_{2} / \mathrm{C},{ }^{194}$ WC, ${ }^{195,196}$, carbon nanotube $(\mathrm{CNT}),{ }^{197}$, activated carbon fiber (ACF), ${ }^{195,197}$ carbon nanofiber (CNF), ${ }^{188,198-200}$ graphene, ${ }^{191}$ have also been widely investigated to further increase the mass transfer and charge transfer. On the other hand, the DFT examinations have also been carried out to help optimize the catalytic activity of Pd-based catalysts, 
which predict that Pd-Ni may have a high EOR activity due to its tuned electronic properites. $^{201}$

\subsubsection{Mechanism of ethanol electro-oxidation on Pd catalyst}

\subsubsection{EOR in AEM-DEFC}

In the case of completely oxidation to $\mathrm{CO}_{2}$, the electro-oxidation of ethanol at the anode takes place as follows: ${ }^{169}$

$$
\mathrm{C}_{2} \mathrm{H}_{5} \mathrm{OH}+12 \mathrm{OH}^{-} \rightarrow 2 \mathrm{CO}_{2}+9 \mathrm{H}_{2} \mathrm{O}+12 e^{-} \quad E^{o}=-0.741 \mathrm{~V} \text { vs. SHE }
$$

On the cathode side: ${ }^{83}$

$$
3 \mathrm{O}_{2}+6 \mathrm{H}_{2} \mathrm{O}+12 e^{-} \longrightarrow 12 \mathrm{OH}^{-} \quad E^{o}=0.401 \mathrm{~V} \text { vs. SHE }
$$

Therefore, the overall reaction of an AEM-DGFC is

$$
\mathrm{C}_{2} \mathrm{H}_{5} \mathrm{OH}+3 \mathrm{O}_{2} \longrightarrow 2 \mathrm{CO}_{2}+3 \mathrm{H}_{2} \mathrm{O} \quad E^{o}=1.145 \mathrm{~V}
$$

The generated $\mathrm{CO}_{2}$ will further react with $\mathrm{OH}^{-}$to generate carbonate, leading to the continuous consumption of $\mathrm{OH}^{-}$in the alkaline electrolyte at the anode:

$$
\mathrm{C}_{2} \mathrm{H}_{5} \mathrm{OH}+16 \mathrm{OH}^{-} \rightarrow 2 \mathrm{CO}_{3}^{2-}+11 \mathrm{H}_{2} \mathrm{O}+12 e^{-} \quad E^{o}=-0.841 \mathrm{~V} \text { vs. SHE }
$$

And the overall reaction will be:

$$
\mathrm{C}_{2} \mathrm{H}_{5} \mathrm{OH}+3 \mathrm{O}_{2}+4 \mathrm{OH}^{-} \longrightarrow 2 \mathrm{CO}_{3}^{2-}+5 \mathrm{H}_{2} \mathrm{O} \quad E^{o}=1.242 \mathrm{~V} \text { vs. SHE }
$$

Indeed, in the real alkaline electrolyte ethanol oxidation reaction, both the in situ FTIR spectroscopic studies ${ }^{182,202,203}$ and HPLC analyses ${ }^{204}$ have demonstrated that the main product is acetate, while only a little amount of $\mathrm{CO}_{2}$ or carbonate was detected. As a result, the anode reaction of ethanol oxidation will be rewritten as:

$$
\mathrm{C}_{2} \mathrm{H}_{5} \mathrm{OH}+5 \mathrm{OH}^{-} \rightarrow \mathrm{CH}_{3} \mathrm{COO}^{-}+4 \mathrm{H}_{2} \mathrm{O}+4 e^{-} \quad E^{o}=-0.926 \mathrm{~V} \text { vs. SHE }
$$

Then the overall reaction will be:

$$
\mathrm{C}_{2} \mathrm{H}_{5} \mathrm{OH}+\mathrm{O}_{2}+\mathrm{OH}^{-} \longrightarrow \mathrm{CH}_{3} \mathrm{COO}^{-}+2 \mathrm{H}_{2} \mathrm{O} \quad E^{o}=1.327 \mathrm{~V} \text { vs. SHE }
$$




\subsubsection{Ethanol electro-oxidation pathway on Pd catalyst}

The oxidation mechanism of ethanol has been widely studied in alkaline media with different techniques, including cyclic voltammetery, ${ }^{30,192,205}$ in situ Fourier Transform Infrared Spectroscopy (FTIRS), ${ }^{202,206,207}$ Surface Enhanced Raman Spectroscopy, Differential Electro-chemical Mass Spectrometry, ${ }^{203}$ and High Performance Liquid Chronometry (HPLC), ${ }^{204}$ etc. A general accepted ethanol electro-oxidation mechanism on Pd is as follows: ${ }^{208}$

$$
\begin{gathered}
\mathrm{Pd}+\mathrm{CH}_{3} \mathrm{CH}_{2} \mathrm{OH} \longleftrightarrow \mathrm{Pd}-\left(\mathrm{CH}_{3} \mathrm{CH}_{2} \mathrm{OH}\right)_{a d s} \\
\mathrm{Pd}-\left(\mathrm{CH}_{3} \mathrm{CH}_{2} \mathrm{OH}\right)_{a d s}+3 \mathrm{OH}^{-} \longrightarrow \mathrm{Pd}-\left(\mathrm{CH}_{3} \mathrm{CO}\right)_{a d s}+3 \mathrm{H}_{2} \mathrm{O}+3 e^{-} \\
\mathrm{Pd}-\left(\mathrm{CH}_{3} \mathrm{CO}\right)_{a d s}+\mathrm{Pd}-\mathrm{OH}_{a d s} \stackrel{r . d . s}{\longrightarrow} \mathrm{Pd}-\mathrm{CH}_{3} \mathrm{COOH}+\mathrm{Pd} \\
\mathrm{Pd}-\mathrm{CH}_{3} \mathrm{COOH}+\mathrm{OH}^{-} \longrightarrow \mathrm{Pd}+\mathrm{CH}_{3} \mathrm{COO}^{-}+\mathrm{H}_{2} \mathrm{O}
\end{gathered}
$$

Within these four steps, reaction (5-10) is the rate determine step (r.d.s.).

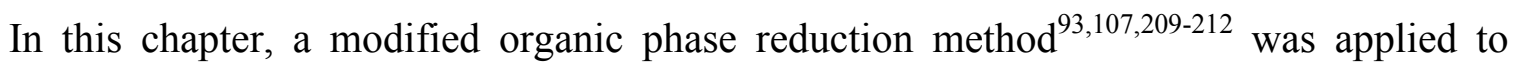
prepare carbon supported Pd-Ni nanoparticles with different Pd-Ni compositions. The asprepared catalysts were characterized by XRD, TEM, HR-TEM, TGA, ICP-AES. The characterizations reveal that these Pd-Ni catalysts have small diameters of $\sim 3 \mathrm{~nm}$ and narrow size distributions. The catalytic activities towards EOR were in $1.0 \mathrm{M} \mathrm{NaOH}+$ $1.0 \mathrm{M} \quad \mathrm{C}_{2} \mathrm{H}_{5} \mathrm{OH}$ by cyclic voltammetry, linear scan voltammetry, and chonoammeperometry, and higher EOR mass activity and stability on $\mathrm{Pd}_{\mathrm{x}} \mathrm{Ni}_{\mathrm{y}} / \mathrm{C}$ catalysts have been demonstrated. We found the EOR activity is strongly correlated with Pd-Ni composition and structure, especially the Pd-Ni interaction/contact on catalyst surface. 


\subsection{Experimental section}

\subsubsection{Preparation of $\mathrm{Pd} / \mathrm{C}, \mathrm{Pd}_{\mathrm{x}} \mathrm{Ni}_{\mathrm{y}} / \mathrm{C}$, and $\mathrm{Pd}_{1} \mathrm{Ni}_{1} / \mathrm{C}-\mathrm{NaBH}_{4}$ catalysts}

The $\mathrm{Pd}_{\mathrm{x}} \mathrm{Ni}_{\mathrm{y}} / \mathrm{C}$ catalysts (x:y is the atomic ratio of $\mathrm{Pd}: \mathrm{Ni}$ ) were synthesized through a modified organic solution phase-based reduction method. ${ }^{33,211,212}$ A typical synthesis procedure for $\mathrm{Pd}_{1} \mathrm{Ni}_{1} / \mathrm{C}$ (atomic ratio of $\mathrm{Pd} \mathrm{Ni}=1: 1$ ) with a $\mathrm{Pd}$ loading of $\sim 20 \mathrm{wt} \%$ is presented as follows. $75.15 \mathrm{mg}$ of $\mathrm{Pd}(\mathrm{acac})_{2}(0.25 \mathrm{mmol}), 73 \mathrm{mg}$ of $\mathrm{Ni}(\mathrm{acac})_{2} \cdot 2 \mathrm{H}_{2} \mathrm{O}(0.25$ $\mathrm{mmol}$ ), and $91 \mathrm{mg}$ of carbon black were mixed in $20 \mathrm{ml}$ of benzyl ether solvent, and heated rapidly up to $100^{\circ} \mathrm{C}$ under a $\mathrm{N}_{2}$ blanket. As the temperature increased to $100^{\circ} \mathrm{C}$, $100 \mu 1$ of oleic acid and $100 \mu 1$ of oleylamine were injected into the system, followed by a quick injection of $1 \mathrm{ml}$ of $\operatorname{LiBet}_{3} \mathrm{H}$. The temperature was held at $100^{\circ} \mathrm{C}$ for 20 minutes, and then slowly raised to $180^{\circ} \mathrm{C}$ and was held there for an additional 30 minutes. The final product $\mathrm{Pd}_{1} \mathrm{Ni}_{1} / \mathrm{C}$ was collected by filtration, washed with copious ethanol ( $>800$ $\mathrm{mL}$ ), dried at $50^{\circ} \mathrm{C}$ overnight in an oven. Following a similar procedure, $\mathrm{Pd} / \mathrm{C}$ and other $\mathrm{Pd}_{\mathrm{x}} \mathrm{Ni}_{\mathrm{y}} / \mathrm{C}$ (including $\mathrm{Pd}_{4} \mathrm{Ni}_{1} / \mathrm{C}, \mathrm{Pd}_{2} \mathrm{Ni}_{1} / \mathrm{C}, \mathrm{Pd}_{4} \mathrm{Ni}_{5} / \mathrm{C}$ and $\mathrm{Pd}_{2} \mathrm{Ni}_{3} / \mathrm{C}$ ) catalysts with the same Pd loading were prepared by adjusting the ratio of metal precursors and the amount of reducing agent $\left(\mathrm{LiBEt}_{3} \mathrm{H}\right)$.

Serving as a control sample, $\mathrm{Pd}_{1} \mathrm{Ni}_{1} / \mathrm{C}$ catalyst with a $\mathrm{Pd}$ loading of $\sim 20 \%$ was also synthesized through a widely used $\mathrm{NaBH}_{4}$ reduction method, ${ }^{187,188,213}$ which can be briefly described as follows: $44 \mathrm{mg}$ of carbon black, $28.5 \mathrm{mg}$ of $\mathrm{NiCl}_{2} \cdot 2 \mathrm{H}_{2} \mathrm{O}$, and 21.3 $\mathrm{mg}$ of $\mathrm{PdCl}_{2}$ were first dispersed in $100 \mathrm{ml}$ deionized (DI) water under a vigorous stirring. After a homogeneous suspension was formed, $30 \mathrm{ml}$ of $\mathrm{NaBH}_{4}(0.02 \mathrm{M})$ aqueous solution was added into the system dropwisely. The reaction was taken place under a $\mathrm{N}_{2}$ blanket at room temperature for 24 hours. The resulted product was collected by filtration, washed with hot DI water, and dried at $70^{\circ} \mathrm{C}$ in an oven, and was named $\mathrm{Pd}_{1} \mathrm{Ni}_{1} / \mathrm{C}$ $\mathrm{NaBH}_{4}$. 


\subsubsection{Physical characterizations}

The composition, morphology, and structure of $\mathrm{Pd} / \mathrm{C}$ and $\mathrm{Pd}_{\mathrm{x}} \mathrm{Ni}_{\mathrm{y}} / \mathrm{C}$ catalysts were analyzed by X-ray diffraction (XRD), transmission election microscopy (TEM), High resolution-TEM (HR-TEM), inductively coupled plasma atomic emission spectroscopy (ICP-AES), and thermogravimetric analysis (TGA).

\subsubsection{Electro-chemical characterizations}

Cyclic voltammetry (CV), linear scan voltammetry (LSV), chronoamperometry (CA) testings of the as-prepared $\mathrm{Pd} / \mathrm{C}$ and $\mathrm{Pd}_{\mathrm{x}} \mathrm{Ni}_{\mathrm{y}} / \mathrm{C}$ catalysts were performed in half cell setups (see Section 2.3.1) at room temperature, with a $\mathrm{Hg} / \mathrm{HgO} / 1.0 \mathrm{M} \mathrm{NaOH}$ reference electrode ( $0.140 \mathrm{~V} v$ s. NHE), while tris(2,4,6-trimethoxyphenyl) polysulfone-methylene quaternary phosphonium hydroxide (TPQPOH) ${ }^{112}$ was applied as the anion-conductive ionomer. The electro-chemical surface area (ECSA) of $\mathrm{Pd} / \mathrm{C}$ and $\mathrm{Pd}_{\mathrm{x}} \mathrm{Ni}_{\mathrm{y}} / \mathrm{C}$ catalysts was studied by a $\mathrm{CV}$ test performed through the procedure detailed in Section 4.2.5. The EOR activity was measured by a $\mathrm{CV}$ test from $-0.87-0.20 \mathrm{~V}$ in $1.0 \mathrm{M} \mathrm{NaOH}+1.0 \mathrm{M} \mathrm{EtOH}$, with the sweep rate of $50 \mathrm{mV} \mathrm{s}^{-1}$. A LSV from $-0.87-0.20 \mathrm{~V}$ was conducted on each catalyst with a sweep rate of $1 \mathrm{mV} / \mathrm{s}$ to obtain the onset potential, Tafel slope and exchange current density. The long-term activity of EOR was investigated through a chronoamperometry test at an applied voltage of $-0.5 \mathrm{~V}$ for 10000 seconds.

The Tafel slope and exchange current density were obtained by the procedure in Section 2.3.1.3. using equation (2-8):

$$
\eta=2.303 \frac{R T}{\alpha n F} \log \left(\frac{j}{j_{0}}\right)
$$

As the main product from ethanol electro-oxidation in alkaline electrolyte has been demonstrated to be acetate, $\mathrm{E}_{\text {theory }}$ is set as $-0.926 \mathrm{~V}$ vs. SHE, which is $-1.066 \mathrm{~V}$ 
vs. $\mathrm{Hg} / \mathrm{HgO} / 1.0 \mathrm{M} \mathrm{NaOH}$. The Tafel slope $b=2.303 \frac{R T}{\alpha n F}$ and exchange current density $\eta$ were derived in the low potential range of -0.55 to $-0.35 \mathrm{~V}$.

\subsection{Results and discussion}

The bulk chemical compositions of $\mathrm{Pd} / \mathrm{C}, \mathrm{Pd}_{\mathrm{x}} \mathrm{Ni}_{\mathrm{y}} / \mathrm{C}$, and $\mathrm{Pd}_{1} \mathrm{Ni}_{1} / \mathrm{C}-\mathrm{NaBH}_{4}$ catalysts were studied by both ICP-AES and TEM-EDS, as summarized in Table 5.2. The atomic ratio of $\mathrm{Pd}$ to $\mathrm{Ni}$ in all the $\mathrm{Pd}_{\mathrm{x}} \mathrm{Ni}_{\mathrm{y}} / \mathrm{C}$ catalysts have been determined to be very close to the setting ratio, indicating that both $\mathrm{Pd}$ and $\mathrm{Ni}$ metal precursors have been fully reduced in the syntheses. The Pd loading of each catalyst has also been calculated through the Pd concentration that was detected by ICP-AES. Due to the existence of a little amount of surfactant on the surface of the as-prepared catalysts, and the formation of $\mathrm{NiO}$ and $\mathrm{Ni}(\mathrm{OH})_{2}$ as the sample is exposed to the air, ${ }^{214}$ the Pd metal loading of all the catalysts has been found lower than the setting loading of $\sim 20 \%$ for all the samples.

Fig. 5.1 shows the TGA curves on $\mathrm{Pd} / \mathrm{C}$ and $\mathrm{Pd}_{1} \mathrm{Ni}_{1} / \mathrm{C}$ catalysts. The first two steps were carried out from R. T. to $500^{\circ} \mathrm{C}$ in inert $\mathrm{N}_{2}$ gas, and the third step is from $500-700^{\circ} \mathrm{C}$ in oxidative air (as shown in the Fig. 5.1 inserted). The temperature-time plots on the two catalysts are identical to each other. Due to the oxidation of metal catalysts at high temperature in the air, the metal loadings detected by TGA $(22 \%$ for $\mathrm{Pd} / \mathrm{C}$ and $30 \%$ for $\mathrm{Pd}_{1} \mathrm{Ni}_{1} / \mathrm{C}$ ) have been found higher than that determined by IPC-ACS. The weight loss at around $100-130^{\circ} \mathrm{C}$ in the TGA curve of $\mathrm{Pd} / \mathrm{C}$ belongs to the evaporation/desorption of water absorbed in the catalyst. The slow weight decreasing from thereafter to $500^{\circ} \mathrm{C}$ is assigned to the gradual decomposition of surfactants in $\mathrm{N}_{2}$, the surfactants on the $\mathrm{Pd} / \mathrm{C}$ surface are around $5 \mathrm{wt} \%$. The huge loss from $500-520^{\circ} \mathrm{C}$ is the rapid oxidation of carbon support in air. The presence of $\mathrm{Ni}(\mathrm{OH})_{2}$ is evidenced by the TGA curve of $\mathrm{Pd}_{1} \mathrm{Ni}_{1} / \mathrm{C}$ with the weight loss present from $190-260^{\circ} \mathrm{C}$, which is attributed to the dehydration of $\mathrm{Ni}(\mathrm{OH})_{2}$ according to the following reaction: ${ }^{215}$

$$
\mathrm{Ni}(\mathrm{OH})_{2} \longrightarrow \mathrm{NiO}+\mathrm{H}_{2} \mathrm{O}
$$


Table 5.2

Summary of physical properties of $\mathrm{Pd} / \mathrm{C}, \mathrm{Pd}_{\mathrm{x}} \mathrm{Ni}_{\mathrm{y}} / \mathrm{C}$, and, $\mathrm{Pd}_{1} \mathrm{Ni}_{1} / \mathrm{C}$ catalysts.

\begin{tabular}{|c|c|c|c|c|c|c|}
\hline & \multicolumn{2}{|c|}{ Atomic ratio } & \multirow{2}{*}{$\begin{array}{c}\text { Pd metal } \\
\text { loading } \\
\text { detected } \\
\text { by ICP- } \\
\text { AES }\end{array}$} & \multicolumn{2}{|c|}{ Diameter (nm) } & \multirow{2}{*}{$\begin{array}{c}\text { Lattice } \\
\text { parameter } \\
\text { calculated } \\
\text { from XRD } \\
\text { (A) }\end{array}$} \\
\hline & $\begin{array}{c}\text { Detected } \\
\text { by ICP- } \\
\text { AES }\end{array}$ & $\begin{array}{c}\text { Detected } \\
\text { by TEM- } \\
\text { EDS }\end{array}$ & & $\begin{array}{l}\text { Calculated } \\
\text { from XRD }\end{array}$ & $\begin{array}{c}\text { Measured } \\
\text { by TEM }\end{array}$ & \\
\hline $\mathrm{Pd} / \mathrm{C}$ & - & - & $18 \%$ & 2.2 & 2.7 & 3.9207 \\
\hline $\mathrm{Pd}_{4} \mathrm{Ni}_{1} / \mathrm{C}$ & $\mathrm{Pd}_{7.25} \mathrm{Ni}_{1}$ & $\mathrm{Pd}_{5.7} \mathrm{Ni}_{1}$ & $17 \%$ & 2.5 & 2.6 & 3.9080 \\
\hline $\mathrm{Pd}_{2} \mathrm{Ni}_{1} / \mathrm{C}$ & $\mathrm{Pd}_{1.91} \mathrm{Ni}_{1}$ & $\mathrm{Pd}_{2.3} \mathrm{Ni}_{1}$ & $17 \%$ & 2.6 & 2.6 & 3.9078 \\
\hline $\mathrm{Pd}_{1} \mathrm{Ni}_{1} / \mathrm{C}$ & $\mathrm{Pd}_{1.03} \mathrm{Ni}_{1}$ & $\mathrm{Pd}_{0.8} \mathrm{Ni}_{1}$ & $15 \%$ & 2.4 & 2.4 & 3.9102 \\
\hline $\mathrm{Pd}_{4} \mathrm{Ni}_{5} / \mathrm{C}$ & $\mathrm{Pd}_{3.86} \mathrm{Ni}_{5}$ & $\mathrm{Pd}_{3.8} \mathrm{Ni}_{5}$ & $16 \%$ & 2.5 & 3.0 & 3.8950 \\
\hline $\mathrm{Pd}_{2} \mathrm{Ni}_{3} / \mathrm{C}$ & $\mathrm{Pd}_{1.99} \mathrm{Ni}_{3}$ & $\mathrm{Pd}_{1.8} \mathrm{Ni}_{3}$ & $16 \%$ & 3.0 & 3.2 & 3.8900 \\
\hline $\begin{array}{c}\mathrm{Pd}_{1} \mathrm{Ni}_{1} / \mathrm{C}- \\
\mathrm{NaBH}_{4} \\
\end{array}$ & $\mathrm{Pd}_{1.25} \mathrm{Ni}_{1}$ & $\mathrm{Pd}_{1.1} \mathrm{Ni}_{1}$ & $16 \%$ & 3.9 & 3.8 & 3.8930 \\
\hline
\end{tabular}

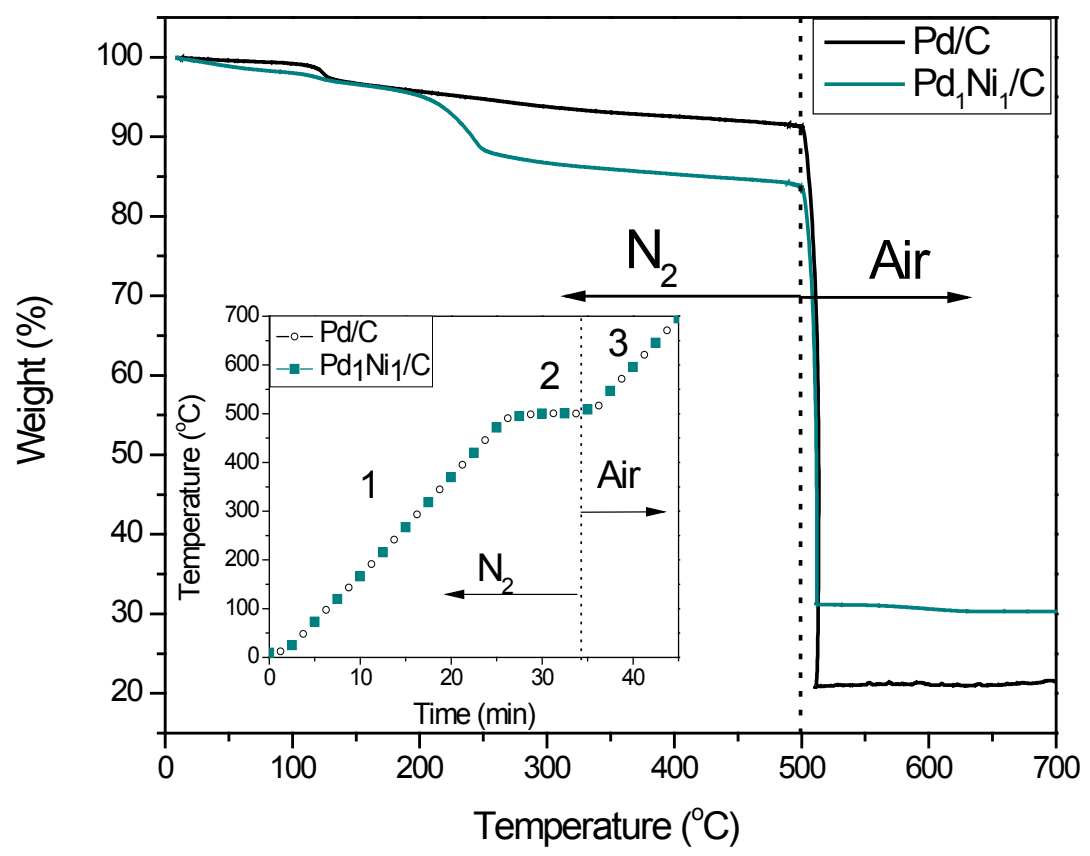

Fig. 5.1 Thermogravimetric analysis plot and temperature plot (inserted) of $\mathrm{Pd} / \mathrm{C}$ and $\mathrm{Pd}_{1} \mathrm{Ni}_{1} / \mathrm{C}$ catalysts. 
The XRD patterns of the $\mathrm{Pd} / \mathrm{C}, \mathrm{Pd}_{\mathrm{x}} \mathrm{Ni}_{\mathrm{y}} / \mathrm{C}$, and $\mathrm{Pd}_{1} \mathrm{Ni}_{1} / \mathrm{C}-\mathrm{NaBH}_{4}$ catalysts are presented in Fig. 5.2 (a) and (b). All of them displayed a typical face-centered cubic (fcc) pattern. The peaks at $39.9^{\circ}, 45.9^{\circ}, 67.9^{\circ}$, and $81.8^{\circ}$ are assigned to the $\mathrm{Pd}(111),(200),(220)$, and (311), respectively, while the peak around $25.2^{\circ}$ is referred to the graphite (002) facet of the carbon support. The Pd (222) diffraction peak at $\sim 86.6^{\circ}$ has also been observed in $\mathrm{Pd}_{1} \mathrm{Ni}_{1} / \mathrm{C}-\mathrm{NaBH}_{4}$ (Fig. 5.2 (b)). No significant peak shift is observed for the $\mathrm{Pd}_{4} \mathrm{Ni}_{1} / \mathrm{C}$, $\mathrm{Pd}_{2} \mathrm{Ni}_{1} / \mathrm{C}$, and $\mathrm{Pd}_{1} \mathrm{Ni}_{1} / \mathrm{C}$, and only small shifts have been detected for the $\mathrm{Pd}_{4} \mathrm{Ni}_{5} / \mathrm{C}$ and $\mathrm{Pd}_{2} \mathrm{Ni}_{3} / \mathrm{C}$ (Fig. 5.2 (a)), and $\mathrm{Pd}_{1} \mathrm{Ni}_{1} / \mathrm{C}-\mathrm{NaBH}_{4}$ (Fig. 5.2 (b)) catalysts, which suggests that $\mathrm{Ni}$ is hard to alloy well with $\mathrm{Pd}$ in the present low preparation temperature. The lattice parameter of the $\mathrm{Pd}_{\mathrm{x}} \mathrm{Ni}_{\mathrm{y}} / \mathrm{C}$ catalyst gets larger (from $3.9080 \AA$ to $3.8900 \AA$ ) with $\mathrm{Ni}$ amount increasing, as shown in Table 5.2. Further, the diffraction peaks of $\mathrm{Pd}_{1} \mathrm{Ni}_{1} / \mathrm{C}$ $\mathrm{NaBH}_{4}$ shift more positively than that of $\mathrm{Pd}_{1} \mathrm{Ni}_{1} / \mathrm{C}$ (Fig. 5.2 (b)), the $\mathrm{Pd}_{1} \mathrm{Ni}_{1} / \mathrm{C}-\mathrm{NaBH}_{4}$ has a lattice parameter of $3.8930 \AA$, which is smaller than $3.9102 \AA$ for $\mathrm{Pd}_{1} \mathrm{Ni}_{1} / \mathrm{C}$. This indicates that the $\mathrm{NaBH}_{4}$ method can facilitate the formation of Pd-Ni alloy. It is reported that a heat treatment at an elevated temperature $\left(>800^{\circ} \mathrm{C}\right)$ will greatly increase the alloy degree of PdNi catalysts. ${ }^{120}$ However, in most cases of synthesis of PdNi catalyst through a $\mathrm{NaBH}_{4}$ reduction method at low temperatures, the alloying between $\mathrm{Pd}$ and $\mathrm{Ni}$ is weak. ${ }^{93,107,211,212}$ Although Ni will be generally oxidized in air, no diffraction peaks of metallic Ni, Ni oxides and Ni hydroxides were observed for all catalysts prepared by the organic solution phase reduction method. This indicates that most of the Ni was amorphous in nature or crystalline only in very small region. ${ }^{214,216}$ The XRD pattern of $\mathrm{Pd}_{1} \mathrm{Ni}_{1} / \mathrm{C}-\mathrm{NaBH}_{4}$ shows two additional peaks at $33.4^{\circ}$ and $59.2^{\circ}$, which are attributed to $\mathrm{Ni}(\mathrm{OH})_{2}(100)$ and (110) facets, respectively. ${ }^{187,217,218}$ This suggests that the presence of $\mathrm{H}_{2} \mathrm{O}$ in the $\mathrm{NaBH}_{4}$ reduction process will facilitate the formation of $\mathrm{Ni}(\mathrm{OH})_{2}$ phase. The average particle sizes are calculated based on Pd (220) peak using Debye-Scherrer formula, and are summarized in Table 5.2. All the $\mathrm{Pd} / \mathrm{C}$ and $\mathrm{Pd}_{\mathrm{x}} \mathrm{Ni}_{\mathrm{y}} / \mathrm{C}$ prepared by the organic solution phase reduction method have a small particle size in the range of $2.2-$ $3.0 \mathrm{~nm}$, while that of $\mathrm{Pd}_{1} \mathrm{Ni}_{1} / \mathrm{C}-\mathrm{NaBH}_{4}$ is $3.9 \mathrm{~nm}$. This strongly suggests the organic solution phase reduction method has more advantages over traditional $\mathrm{NaBH}_{4}$ method in controlling the particle size. 
Typical TEM images of the $\mathrm{Pd} / \mathrm{C}, \mathrm{Pd}_{\mathrm{x}} \mathrm{Ni}_{\mathrm{y}} / \mathrm{C}$, and $\mathrm{Pd}_{1} \mathrm{Ni}_{1} / \mathrm{C}-\mathrm{NaBH}_{4}$ catalysts are shown in Fig. 5.3. The average diameters of all the catalysts are summarized in Table 5.2. The particle sizes measured from TEM images are in good agreement with those calculated by XRD. All the catalysts prepared by the organic solution phase reduction method are spherical and homogeneously dispersed on Vulcan XC-72R with no remarkable observation of agglomeration. The particle size histograms evaluated from 100 random particles in an arbitrarily chosen area present a narrow distribution of $1-6 \mathrm{~nm}$ for all catalysts prepared by the organic solution phase reduction method. In contrast, the particle size distribution of $\mathrm{Pd}_{1} \mathrm{Ni}_{1} / \mathrm{C}-\mathrm{NaBH}_{4}$ is broader $(1-10 \mathrm{~nm})$, with some very large particles in TEM image (as shown in Fig. 5.3 (g)). The HR-TEM images of $\mathrm{Pd}_{1} \mathrm{Ni}_{1} / \mathrm{C}$ and $\mathrm{Pd}_{1} \mathrm{Ni}_{1} / \mathrm{C}-\mathrm{NaBH}_{4}$ are shown in Fig. 5.4. It is clearly observed that $\mathrm{Pd}_{1} \mathrm{Ni}_{1} / \mathrm{C}$ has a smaller particle size than $\mathrm{Pd}_{1} \mathrm{Ni}_{1} / \mathrm{C}-\mathrm{NaBH}_{4}$. In addition, the HR-TEM images show that both two catalysts have the same type of lattice fringe with an interplanar spacing of $\sim 0.24 \mathrm{~nm}$, indicating that they are covered by Pd (111) plane. 

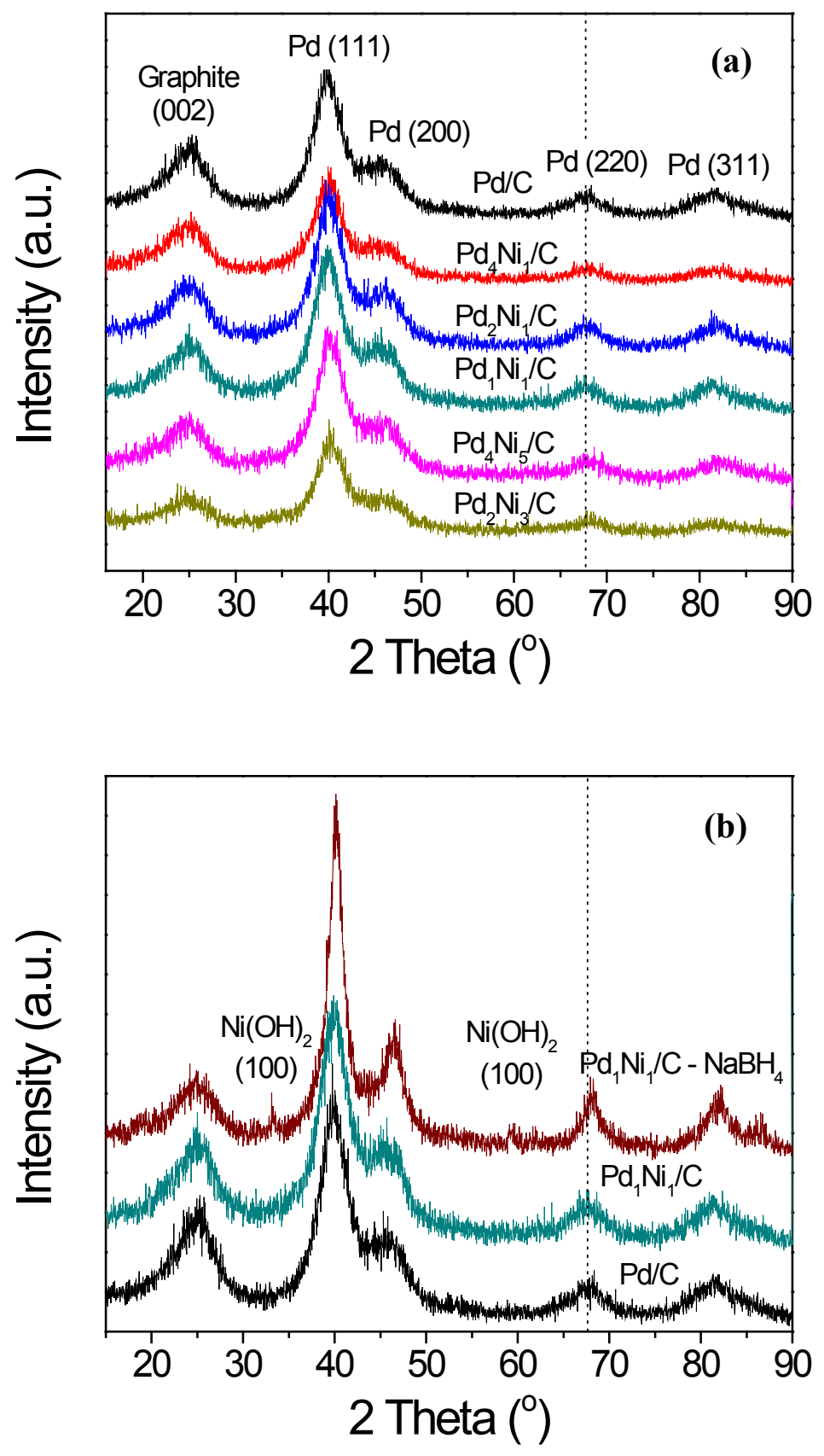

Fig. 5.2 XRD patterns of (a) $\mathrm{Pd} / \mathrm{C}$ and $\mathrm{Pd}_{\mathrm{x}} \mathrm{Ni}_{\mathrm{y}} / \mathrm{C}$ samples with different $\mathrm{Pd}: \mathrm{Ni}$ compositions prepared by the organic solution phase reduction method; and (b) $\mathrm{Pd}_{1} \mathrm{Ni}_{1} / \mathrm{C}$ samples prepared by the organic solution phase reduction and $\mathrm{NaBH}_{4}$ reduction methods. 

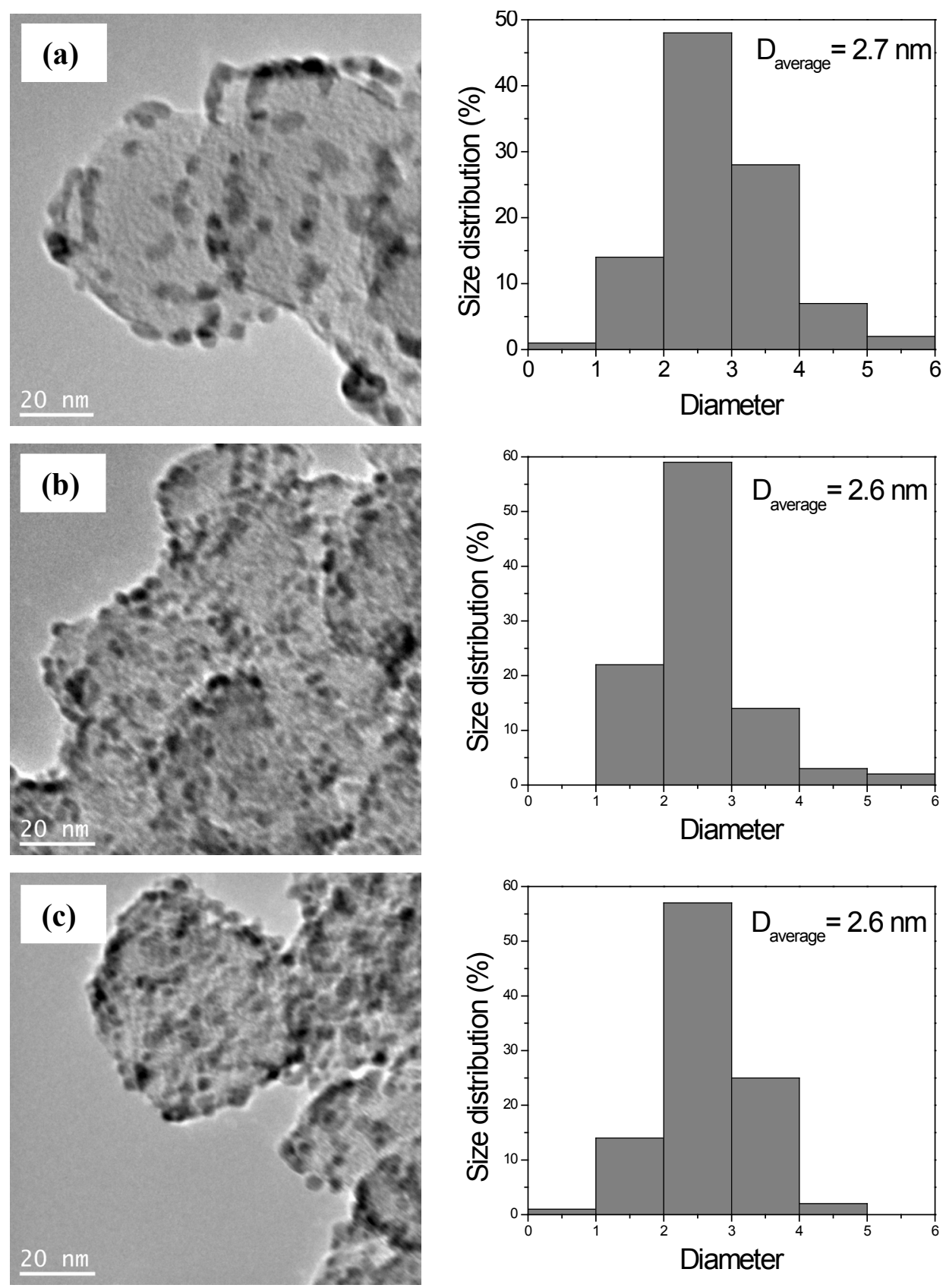

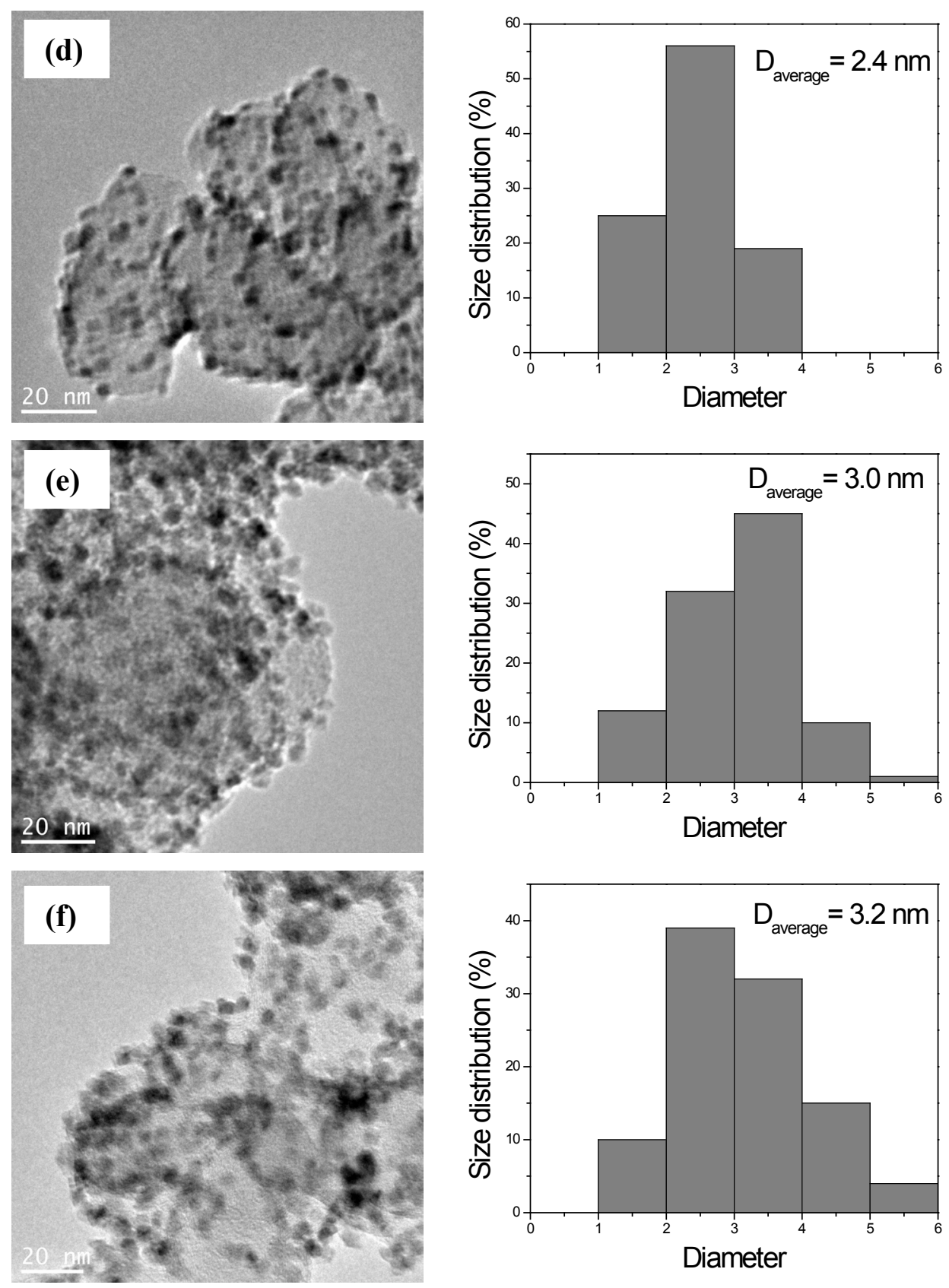

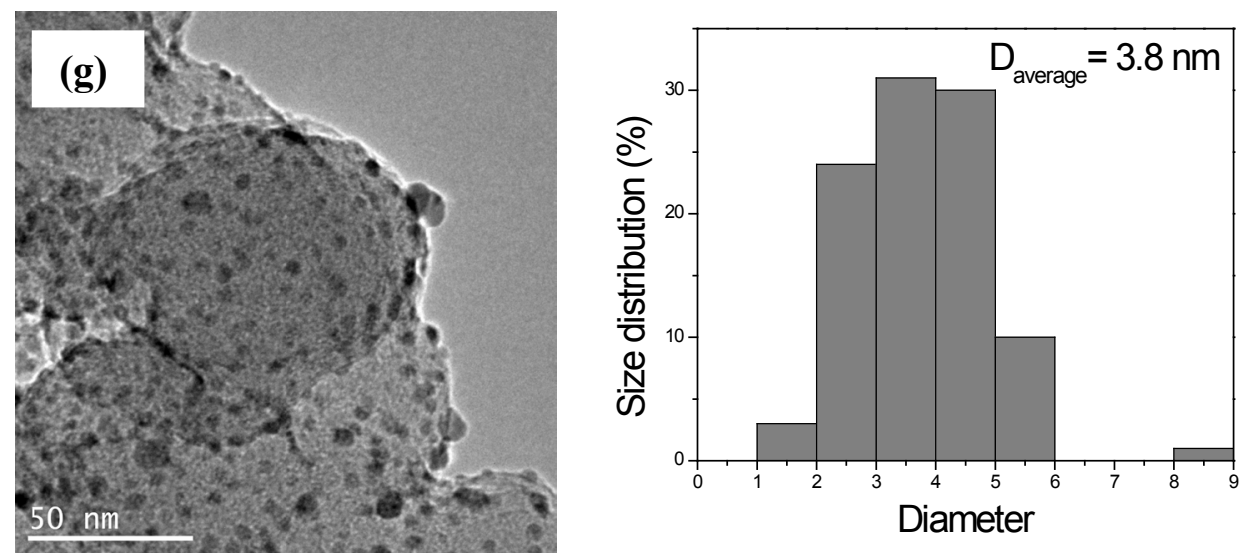

Fig. 5.3 TEM images of (a) $\mathrm{Pd} / \mathrm{C}$, (b) $\mathrm{Pd}_{4} \mathrm{Ni}_{1} / \mathrm{C}$, (c) $\mathrm{Pd}_{2} \mathrm{Ni}_{1} / \mathrm{C}$, (d) $\mathrm{Pd}_{1} \mathrm{Ni}_{1} / \mathrm{C}$, (e) $\mathrm{Pd}_{4} \mathrm{Ni}_{5} / \mathrm{C}$, (f) $\mathrm{Pd}_{2} \mathrm{Ni}_{3} / \mathrm{C}$, and (g) $\mathrm{Pd}_{1} \mathrm{Ni}_{1} / \mathrm{C}-\mathrm{NaBH}_{4}$ catalysts.
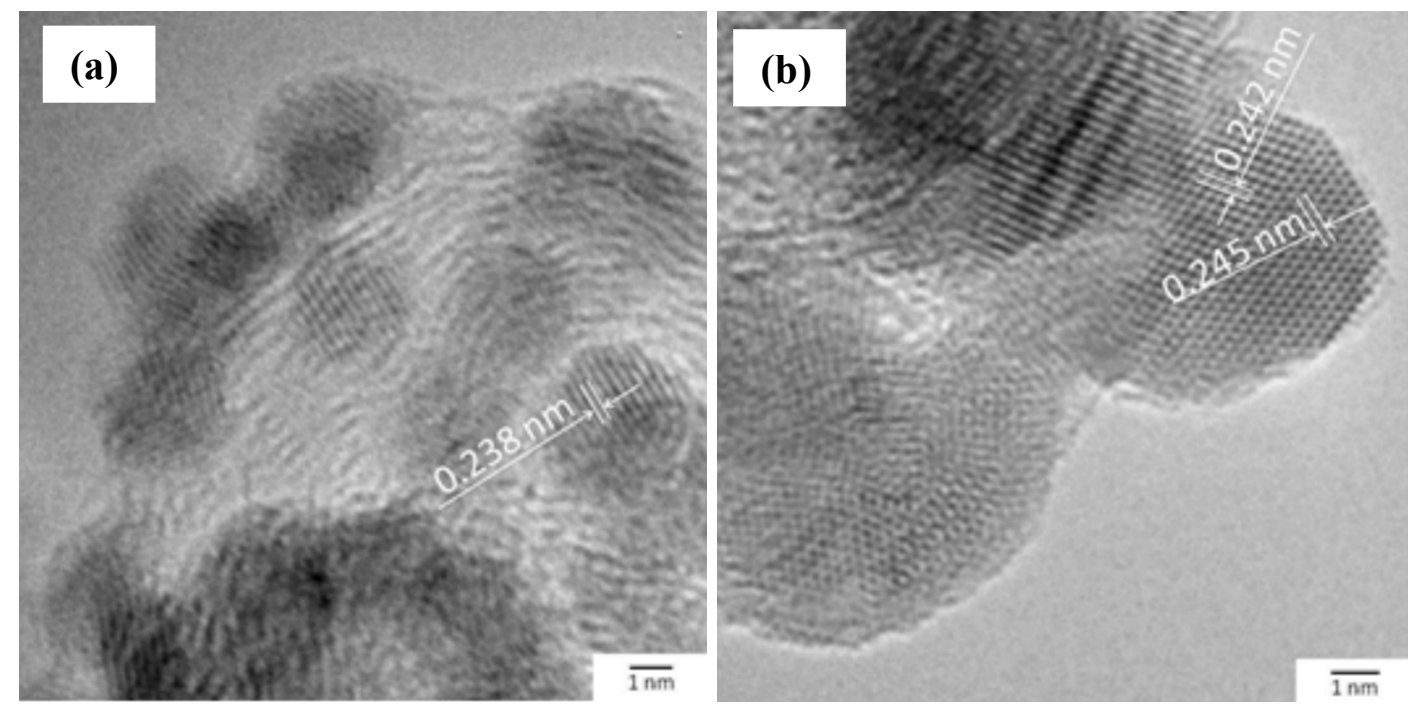

Fig. 5.4 HR-TEM images of (a) $\mathrm{Pd}_{1} \mathrm{Ni}_{1} / \mathrm{C}$ and (b) $\mathrm{Pd}_{1} \mathrm{Ni}_{1} / \mathrm{C}-\mathrm{NaBH}_{4}$, both showing $\mathrm{Pd}$ (111)-rich surface.

The cyclic voltammetries of $\mathrm{Pd} / \mathrm{C}, \mathrm{Pd}_{\mathrm{x}} \mathrm{Ni}_{\mathrm{y}} / \mathrm{C}$, and $\mathrm{Pd}_{1} \mathrm{Ni}_{1} / \mathrm{C}-\mathrm{NaBH}_{4}$ catalysts were investigated in $1.0 \mathrm{M} \mathrm{NaOH}$ solution and are shown in Fig. 5.5 (a) and (b). The polarization curves clearly show that both $\mathrm{Pd}$ and $\mathrm{Ni}$ are present on all $\mathrm{Pd}_{\mathrm{x}} \mathrm{Ni}_{\mathrm{y}} / \mathrm{C}$ and $\mathrm{Pd}_{1} \mathrm{Ni}_{1} / \mathrm{C}-\mathrm{NaBH}_{4}$ catalysts. On the pure $\mathrm{Pd} / \mathrm{C}$ polarization curve, a small peak at $\sim-0.3 \mathrm{~V}$ is ascribed to the water activation on $\mathrm{Pd} .{ }^{216}$ However, when combined with $\mathrm{Ni}$, this peak was suppressed and a broad peak at $\sim-0.53 \mathrm{~V}$ appeared instead, which can be assigned to the $\mathrm{OH}^{-}$adsorption on the surface of the $\mathrm{Pd}_{\mathrm{x}} \mathrm{Ni}_{\mathrm{y}} / \mathrm{C}$ catalysts. The presence of both $\mathrm{Pd}$ and $\mathrm{Ni}$ in the $\mathrm{Pd}_{\mathrm{x}} \mathrm{Ni}_{\mathrm{y}} / \mathrm{C}$ and $\mathrm{Pd}_{2} \mathrm{Ni}_{3} / \mathrm{C}-\mathrm{NaBH}_{4}$ catalysts can also be confirmed by the oxidation 
peak of $\mathrm{Ni}(\mathrm{OH})_{2}$ to $\mathrm{NiOOH}$ in the anodic sweep, and the reduction of $\mathrm{NiOOH}$ to $\mathrm{Ni}(\mathrm{OH})_{2}$ in the cathodic sweep at the region $>0.3 \mathrm{~V},{ }^{189,190,216}$ and the reduction of $\mathrm{PdO}$ to $\mathrm{Pd}$ at $0.3 \mathrm{~V}^{219,220}$ The ECSAs of the $\mathrm{Pd}, \mathrm{Pd}_{\mathrm{x}} \mathrm{Ni}_{\mathrm{y}} / \mathrm{C}$, and $\mathrm{Pd}_{1} \mathrm{Ni}_{1} / \mathrm{C}-\mathrm{NaBH}_{4}$ catalysts were calculated by the charge of the reduction region of $\mathrm{PdO}$ to $\mathrm{Pd}$, and are summarized in Table 5.3. It is clear that $\mathrm{Pd}_{4} \mathrm{Ni}_{1} / \mathrm{C}, \mathrm{Pd}_{2} \mathrm{Ni}_{1} / \mathrm{C}$, and $\mathrm{Pd}_{1} \mathrm{Ni}_{1} / \mathrm{C}$ catalysts possess high ECSAs, which is probably due to their small particle sizes. Meanwhile, a trend of decreasing in ECSA has been found on the $\mathrm{Pd}_{\mathrm{x}} \mathrm{Ni}_{\mathrm{y}} / \mathrm{C}$ with a high $\mathrm{Ni}$ concentration. As discussed above, $\mathrm{Pd}$ and $\mathrm{Ni}$ could not alloy well using the organic solution phase reduction method, the trend of decreasing in ECSA indicated that a portion of the surface $\mathrm{Pd}$ active sites were covered by excessive $\mathrm{Ni}$ or Ni derivatives. The Ni-rich surface on the organic solution phase reduction synthesized $\mathrm{Pd}_{\mathrm{x}} \mathrm{Ni}_{\mathrm{y}} / \mathrm{C}$ catalysts was more obvious when comparing the $\mathrm{CV}$ curves of $\mathrm{Pd}_{1} \mathrm{Ni}_{1} / \mathrm{C}$ and $\mathrm{Pd}_{1} \mathrm{Ni}_{1} / \mathrm{C}-\mathrm{NaBH}_{4}$. Although the HR-TEM images clearly show that the two catalysts have the same Pd (111) surface plane, the CV curve of $\mathrm{Pd}_{1} \mathrm{Ni}_{1} / \mathrm{C}$ presents a pair of $\mathrm{Ni}(\mathrm{OH})_{2}-\mathrm{NiOOH}$ oxidation-reduction peak, which is much larger than that of $\mathrm{Pd}_{1} \mathrm{Ni}_{1} / \mathrm{C}-\mathrm{NaBH}_{4}$ (as shown in Fig. 5.5(b)). This implies that even with the same overall atomic ratio, more $\mathrm{Ni}$ is located on the surface of the organic solution phase reduction synthesized $\mathrm{Pd}_{1} \mathrm{Ni}_{1} / \mathrm{C}$ catalyst. This is consistent with the XRD results. With a better alloy structure, $\mathrm{Pd}_{1} \mathrm{Ni}_{1} / \mathrm{C}-\mathrm{NaBH}_{4}$ has more $\mathrm{Ni}$ inserted into $\mathrm{Pd}$ lattice, leading to a relatively less amount of Ni remaining on the surface. As a benefit of having a small diameter, the organic solution phase reduction method synthesized $\mathrm{Pd}_{1} \mathrm{Ni}_{1} / \mathrm{C}$ catalyst has a larger electro-chemical surface area (ECSA) than $\mathrm{Pd}_{1} \mathrm{Ni}_{1} / \mathrm{C}$ $\mathrm{NaBH}_{4}$, therefore, it has more Pd active sites. 

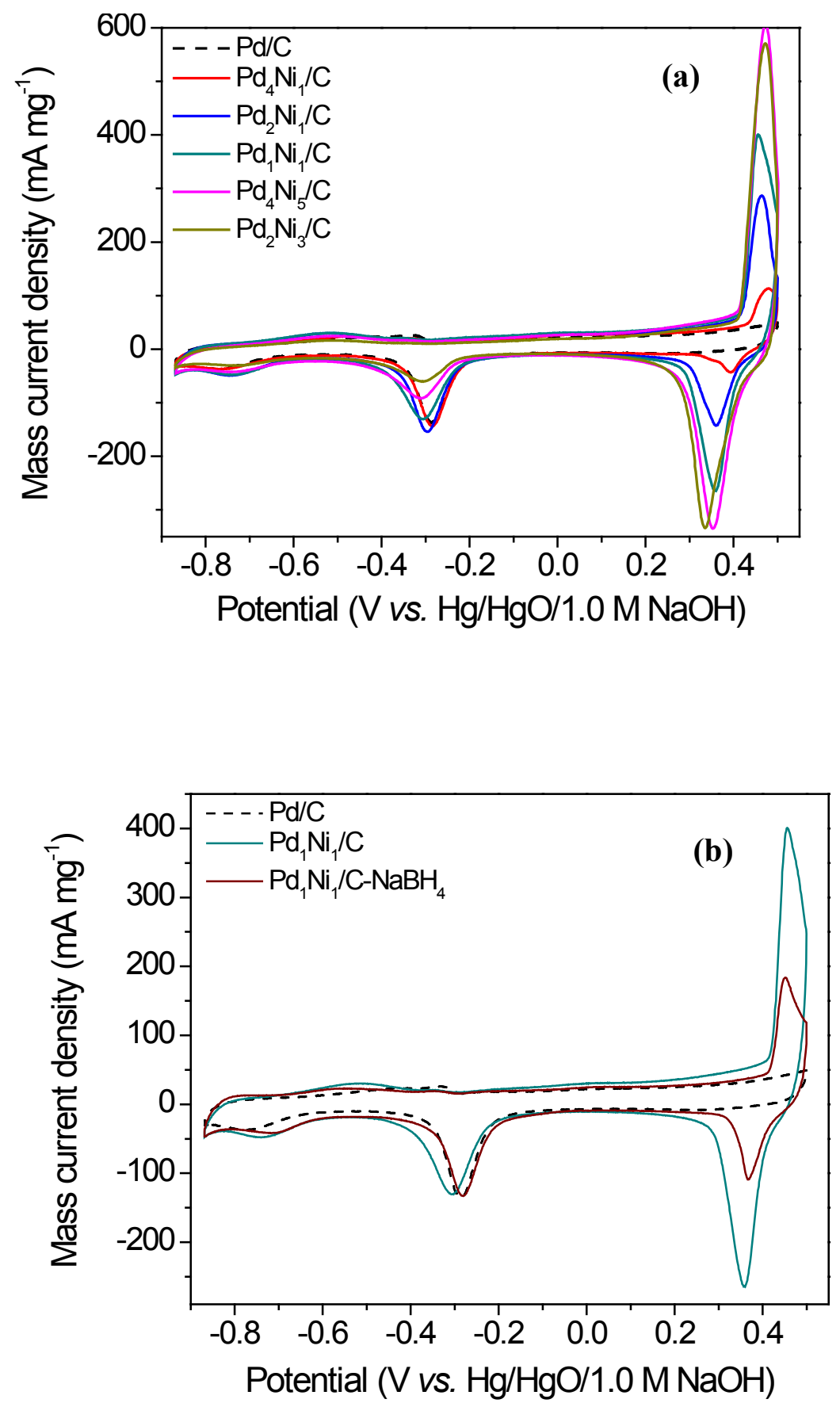

Fig. 5.5 Cyclic voltammograms of (a) $\mathrm{Pd} / \mathrm{C}$ and $\mathrm{Pd}_{\mathrm{x}} \mathrm{Ni}_{\mathrm{y}} / \mathrm{C}$ prepared by the organic solution phase reduction method and (b) $\mathrm{Pd} / \mathrm{C}, \mathrm{Pd}_{1} \mathrm{Ni}_{1} / \mathrm{C}$, and $\mathrm{Pd}_{1} \mathrm{Ni}_{1} / \mathrm{C}-\mathrm{NaBH}_{4}$ in $1.0 \mathrm{M}$ $\mathrm{NaOH}$, at $50 \mathrm{mV} / \mathrm{s}$, room temperature. 

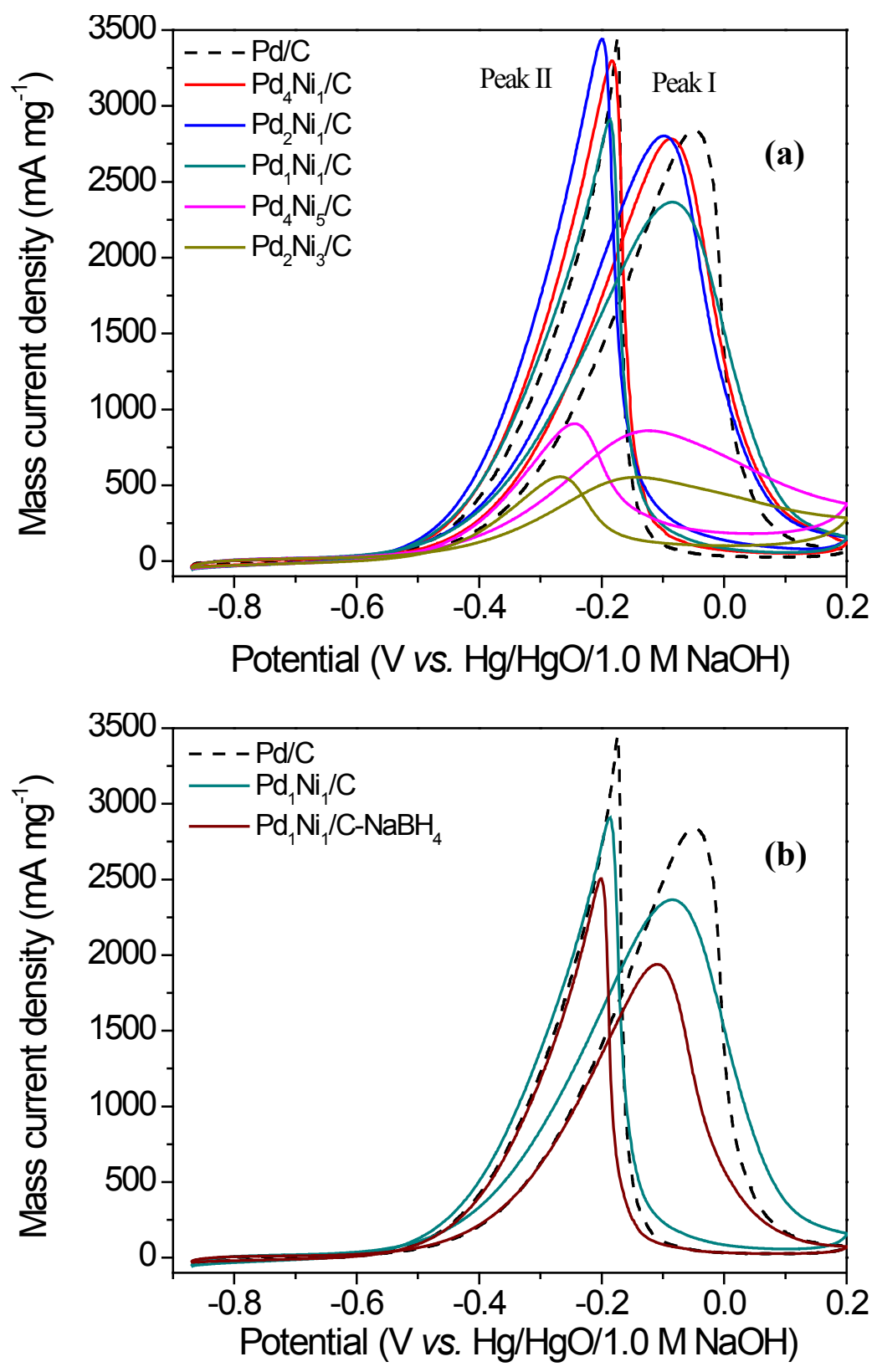

Fig. 5.6 Cyclic voltammograms of ethanol oxidation reaction on (a) $\mathrm{Pd} / \mathrm{C}$ and $\mathrm{Pd}_{\mathrm{x}} \mathrm{Ni}_{\mathrm{y}} / \mathrm{C}$ prepared by the organic solution phase reduction method and (b) $\mathrm{Pd} / \mathrm{C}, \mathrm{Pd}_{1} \mathrm{Ni}_{1} / \mathrm{C}$, and $\mathrm{Pd}_{1} \mathrm{Ni}_{1} / \mathrm{C}-\mathrm{NaBH}_{4}$ in $1.0 \mathrm{M} \mathrm{NaOH}+1.0 \mathrm{M}$ ethanol, $50 \mathrm{mV} \mathrm{s}^{-1}$, room temperature. 


\section{Table 5.3}

Electro-chemical surface area (ECSA), mass activity, and specific activity on $\mathrm{Pd} / \mathrm{C}$, $\mathrm{Pd}_{\mathrm{x}} \mathrm{Ni}_{\mathrm{y}} / \mathrm{C}$, and, $\mathrm{Pd}_{1} \mathrm{Ni}_{1} / \mathrm{C}$ catalysts.

\begin{tabular}{|c|c|c|c|c|c|}
\hline & \multirow{2}{*}{$\begin{array}{l}\text { ECSA } \\
\left(\mathrm{m}^{2} \mathrm{~g}^{-1}\right)\end{array}$} & \multicolumn{2}{|c|}{$\begin{array}{l}\text { MA at Peak I } \\
\left(\mathrm{mA} \mathrm{mg}^{-1} \mathrm{Pd}\right)\end{array}$} & \multicolumn{2}{|c|}{$\begin{array}{c}\text { SA at Peak I } \\
\left(\mathrm{A} \mathrm{m}^{-2}\right)\end{array}$} \\
\hline & & at $50 \mathrm{mV} \mathrm{s}^{-1}$ & at $1 \mathrm{mV} \mathrm{s}^{-1}$ & at $50 \mathrm{mV} \mathrm{s}^{-1}$ & at $1 \mathrm{mV} \mathrm{s}^{-1}$ \\
\hline $\mathrm{Pd} / \mathrm{C}$ & 58.0 & 2831.74 & 729.62 & 48.80 & 12.57 \\
\hline $\mathrm{Pd}_{4} \mathrm{Ni}_{1} / \mathrm{C}$ & 63.8 & 2779.80 & 906.59 & 43.59 & 14.22 \\
\hline $\mathrm{Pd}_{2} \mathrm{Ni}_{1} / \mathrm{C}$ & 68.0 & 2956.62 & 1197.24 & 43.50 & 17.61 \\
\hline $\mathrm{Pd}_{1} \mathrm{Ni}_{1} / \mathrm{C}$ & 67.3 & 2368.22 & 1247.51 & 35.18 & 18.53 \\
\hline $\mathrm{Pd}_{4} \mathrm{Ni}_{5} / \mathrm{C}$ & 48.3 & 856.79 & 444.88 & 17.76 & 9.22 \\
\hline $\mathrm{Pd}_{2} \mathrm{Ni}_{3} / \mathrm{C}$ & 32.9 & 544.22 & 315.62 & 16.56 & 9.60 \\
\hline $\begin{array}{c}\mathrm{Pd}_{1} \mathrm{Ni}_{1} / \mathrm{C}- \\
\mathrm{NaBH}_{4}\end{array}$ & 58.1 & 1938.43 & 960.37 & 33.34 & 16.52 \\
\hline
\end{tabular}

The EOR polarization curves on the $\mathrm{Pd} / \mathrm{C}, \mathrm{Pd}_{\mathrm{x}} \mathrm{Ni}_{\mathrm{y}} / \mathrm{C}$, and $\mathrm{Pd}_{1} \mathrm{Ni}_{1} / \mathrm{C}-\mathrm{NaBH}_{4}$ catalysts are presented in Fig. 5.6 (a) and (b), and are all characterized by two well-defined peaks. The first, designated as Peak I, is centered at $\sim-0.08 \mathrm{~V}$ in the anodic sweep curve, and the second, Peak II, is centered at $\sim-0.17 \mathrm{~V}$ in the cathodic sweep curve. The mass activity (MA) of $\mathrm{Pd} / \mathrm{C}, \mathrm{Pd}_{\mathrm{x}} \mathrm{Ni}_{\mathrm{y}} / \mathrm{C}$, and $\mathrm{Pd}_{1} \mathrm{Ni}_{1} / \mathrm{C}-\mathrm{NaBH}_{4}$ catalysts at peak I and its corresponding specific activity (SA) after being normalized by ECSA are summarized in Table 5.3.

As is shown in Section 5.1.3.2, the ethanol electro-oxidation on Pd taken place as follows:

$$
\begin{gathered}
\mathrm{Pd}+\mathrm{CH}_{3} \mathrm{CH}_{2} \mathrm{OH} \longleftrightarrow \mathrm{Pd}-\left(\mathrm{CH}_{3} \mathrm{CH}_{2} \mathrm{OH}\right)_{a d s} \\
\mathrm{Pd}-\left(\mathrm{CH}_{3} \mathrm{CH}_{2} \mathrm{OH}\right)_{a d s}+3 \mathrm{OH}^{-} \longrightarrow \mathrm{Pd}-\left(\mathrm{CH}_{3} \mathrm{CO}\right)_{a d s}+3 \mathrm{H}_{2} \mathrm{O}+3 e^{-} \\
\mathrm{Pd}-\left(\mathrm{CH}_{3} \mathrm{CO}\right)_{a d s}+\mathrm{Pd}-\mathrm{OH}_{a d s} \stackrel{r . d . s}{\longrightarrow} \mathrm{Pd}-\mathrm{CH}_{3} \mathrm{COOH}+\mathrm{Pd} \\
\mathrm{Pd}-\mathrm{CH}_{3} \mathrm{COOH}+\mathrm{OH}^{-} \longrightarrow \mathrm{Pd}+\mathrm{CH}_{3} \mathrm{COO}^{-}+\mathrm{H}_{2} \mathrm{O}
\end{gathered}
$$

In the course of the anodic sweep, reactions (5-8) and (5-9) are generally accepted to happen at a potential region of $<-0.7 \mathrm{~V}$. The $\mathrm{CH}_{3} \mathrm{CO}_{\text {ads }}$ or other carbonaceous reaction 
intermediates will strongly absorb on the surface of $\mathrm{Pd}$ and block the active site. Reactions (5-10) and (5-11) take place in the region starting from $-0.7 \mathrm{~V}$, where $\mathrm{Pd}$ begins to adsorb $\mathrm{OH}^{-}$. With the adsorption of hydroxyl on $\mathrm{Pd}$, the strongly absorbed carbonaceous species will be quickly stripped away, and result in an increasing current. However, at a higher potential, the formation of $\mathrm{PdO}$ will block the further adsorption of reactive species and lead to a remarkable decrease in current. ${ }^{182,205,221}$ In the cathodic sweep, the previously formed $\mathrm{PdO}$ will be reduced to catalytic active $\mathrm{Pd}$, thus, leading to the recovery of EOR current. Peak II is assigned by some authors to the removal of carbonaceous species that are not completely oxidized in the anodic scan. ${ }^{199,222}$ However, no solid evidence has ever been reported to support their proposed mechanism that the intermediates generated in the forward scan will strongly bond on the surface of $\mathrm{PdO}$ in alkaline solution in high-potential range. Therefore, it is reasonable to believe these intermediates should diffuse into the bulk electrolyte. When PdO was reduced to Pd, the newly-produced catalytic surface should be directly exposed to fresh ethanol. The high potential and the quick adsorption of $\mathrm{OH}^{-}$will benefit the generation of high current density and lead to a sharp anodic peak.

As can be seen in equation (5-10), ethanol oxidation is determined by the degree of coverage of both $\mathrm{CH}_{3} \mathrm{CO}_{\text {ads }}$ and $\mathrm{OH}_{\text {ads }}$. Therefore, when $\mathrm{Ni}$ is involved, the formed $\mathrm{Ni}(\mathrm{OH})_{2}$ on the surface of Pd-based catalysts will facilitate the ethanol oxidation by increasing $\mathrm{OH}$ at lower potential range species, and result in the decrease of onset potential, as shown in Fig 5.6 (a). However, as the Ni amount increases, the specific activity (SA) at Peak I reduces monotonically from $48.80 \mathrm{~A} \mathrm{~m}^{-2}$ for $\mathrm{Pd} / \mathrm{C}$ to $16.56 \mathrm{~A} \mathrm{~m}^{-2}$ for $\mathrm{Pd}_{2} \mathrm{Ni}_{3} / \mathrm{C}$. This degradation may rise for two possible reasons. First, $\mathrm{Ni}(\mathrm{OH})_{2}$ formed during the test will increase the concentration of $\mathrm{OH}^{-}$and/or $\mathrm{OH}_{\mathrm{ads}}$. If the concentration is too high, it will reduce/block the transportation of ethanol to Pd active sites, leading to the reduction of $\mathrm{Pd}-\mathrm{CH}_{3} \mathrm{CO}_{\text {ads. }}$ Second, more $\mathrm{Ni}$ was covered on the surface of the organic solution phase reduction synthesized $\mathrm{Pd}_{\mathrm{x}} \mathrm{Ni}_{\mathrm{y}} / \mathrm{C}$ catalysts, if $\mathrm{Ni}$ is in excess, it will block the Pd active sites, and thus, reduce the overall EOR catalytic activity. 
When compared to the traditional $\mathrm{NaBH}_{4}$ reduction method, the present organic solution phase reduction method shows a great advantage in improving the EOR activity, which can be seen in Fig 5.6 (b) and Table 5.3. The organic solution phase reduction synthesized $\mathrm{Pd}_{1} \mathrm{Ni}_{1} / \mathrm{C}$ possesses both a lower onset potential and higher SA. As examined by the HR-TEM images in Fig. 5.4, both $\mathrm{Pd}_{1} \mathrm{Ni}_{1} / \mathrm{C}$ and $\mathrm{Pd}_{1} \mathrm{Ni}_{1} / \mathrm{C}-\mathrm{NaBH}_{4}$ have the same $\operatorname{Pd}$ (111) surface. Therefore, the geometric effects can be neglected. The main reason for the EOR enhancement on $\mathrm{Pd}_{1} \mathrm{Ni}_{1} / \mathrm{C}$ lies in a special $\mathrm{Pd}-\mathrm{Ni}$ synthetic effect, which is originated from the better contact or more efficient co-operation between $\mathrm{Pd}$ and $\mathrm{Ni}$ on the catalysts. Moreover, due to the small particle size and narrow size distribution, the $\mathrm{MA}$ of $\mathrm{Pd}_{1} \mathrm{Ni}_{1} / \mathrm{C}$ can reach $2368.22 \mathrm{~mA} \mathrm{mg}^{-1}$ Pd, which is $429.79 \mathrm{~mA} \mathrm{mg}^{-1}{ }_{\mathrm{Pd}}$ higher than the corresponding $\mathrm{NaBH}_{4}$ reduced catalyst $\left(1938.43 \mathrm{~mA} \mathrm{mg}^{-1}\right.$ Pd). It needs to be mentioned that the MAs of both the $\mathrm{Pd}_{1} \mathrm{Ni}_{1} / \mathrm{C}$ and $\mathrm{Pd}_{1} \mathrm{Ni}_{1} / \mathrm{C}-\mathrm{NaBH}_{4}$ reported in this study are higher than that of previously reported $\mathrm{PdNi} / \mathrm{C}\left(1136.13 \mathrm{~mA} \mathrm{mg}^{-1}{ }_{\mathrm{Pd}}\right)$ under identical test conditions. ${ }^{187}$ The MAs of the organic solution phase reduction synthesized $\mathrm{Pd}_{4} \mathrm{Ni}_{1} / \mathrm{C}$, $\mathrm{Pd}_{2} \mathrm{Ni}_{1} / \mathrm{C}$ and $\mathrm{Pd}_{1} \mathrm{Ni}_{1} / \mathrm{C}$ catalysts are also higher than other reported results on Pd-based catalysts. ${ }^{179,193,197,198,223}$ Since the $\mathrm{Pd}_{1} \mathrm{Ni}_{1} / \mathrm{C}-\mathrm{NaBH}_{4}$ was prepared by a surfactant-free method, the surface of catalysts is clean. Thus, this catalyst has very little surfactant effects. These results indicate that a small amount of surfactants (OAc and OAm, around $5 \mathrm{wt} \%$ determined by TGA) on $\mathrm{Pd}_{\mathrm{x}} \mathrm{Ni}_{\mathrm{y}} / \mathrm{C}$ will not apparently affect the EOR activities.

To further study the EOR mechanism, a conventional linear sweep voltammogram of EOR has been carried out on $\mathrm{Pd} / \mathrm{C}, \mathrm{Pd}_{\mathrm{x}} \mathrm{Ni}_{\mathrm{y}} / \mathrm{C}, \mathrm{Pd}_{1} \mathrm{Ni}_{1} / \mathrm{C}-\mathrm{NaBH}_{4}$ catalysts at a scan rate of $1 \mathrm{mV} \mathrm{s}^{-1}$ in $1.0 \mathrm{M} \mathrm{NaOH}+1.0 \mathrm{M} \mathrm{C}_{2} \mathrm{H}_{5} \mathrm{OH}$, and the results are shown in Fig. 5.7. It is reasonable to consider the ethanol oxidation reaction taking place on catalysts in such slow sweep rate to be at quasi-steady state, therefore, this method minimizes the mass transfer/diffusion issues. The MA and SA at the peak current of EOR at quasi-steady state are summarized in Table 5.3. The data shows that the addition of $\mathrm{Ni}$ at a certain content can significantly increase the EOR activity on Pd, while too much of $\mathrm{Ni}$ will cause the drop of EOR activity. The surface concentration of Ni also significantly affects the onset potentials. As shown in Table 5.4, the lowest onset potential of $-801 \mathrm{mV}$ has been achieved on $\mathrm{Pd}_{4} \mathrm{Ni}_{5} / \mathrm{C}$, which is $180 \mathrm{mV}$ more negative than that of $\mathrm{Pd} / \mathrm{C}$. In light of 
XRD and TEM analysis, the discrepancies of $\mathrm{Pd}$ and $\mathrm{Pd}_{\mathrm{x}} \mathrm{Ni}_{\mathrm{y}}$ metal particle size and distributions on carbon black support were rather small and contributed little to the enhanced EOR activity. The changes in catalytic activity and onset potential mainly rely on the synergistic effect between $\mathrm{Pd}$ and $\mathrm{Ni}$. The major existing Ni species during the test is $\mathrm{Ni}(\mathrm{OH})_{2}$, which has a point of zero charge $(\mathrm{PZC})$ varying from $\mathrm{pH}=8.8 \sim 11.224-226$ Therefore, $\mathrm{Ni}(\mathrm{OH})_{2}$ in $1.0 \mathrm{M} \mathrm{NaOH}$ solution would absorb $\mathrm{OH}^{-}$and increase the $\mathrm{OH}^{-}$ local concentration around the catalysts nanoparticles. The rise of local $\mathrm{OH}^{-}$ concentration will further lead to the enhancement of $\mathrm{OH}_{\mathrm{ads}}$, which is evidenced by the broad peak on $\mathrm{Pd}_{\mathrm{x}} \mathrm{Ni}_{\mathrm{y}} / \mathrm{C}$ catalysts in Fig. 5.5 (a), centered at $\sim-0.53 \mathrm{~V}$. As the ethanol oxidation is related with both $\mathrm{CH}_{3} \mathrm{CO}_{\text {ads }}$ and $\mathrm{OH}_{\text {ads }}$, the addition of $\mathrm{Ni}$ on surface will increase the coverage of $\mathrm{OH}_{\text {ads }}$ and accelerate the reaction rate to some extent. Since the adsorption of $\mathrm{OH}^{-}$on pure $\mathrm{Pd}$ in alkaline electrolyte is generally accepted to from $-0.7 \mathrm{~V}$ vs. $\mathrm{Hg} / \mathrm{HgO} / 1.0 \mathrm{M} \mathrm{NaOH}$ electrode, the EOR onset potential of $-0.621 \mathrm{~V}$ on the $\mathrm{Pd} / \mathrm{C}$ catalyst is a little above $-0.7 \mathrm{~V}$, indicating that a certain amount of $\mathrm{OH}_{\mathrm{ads}}$ coverage is essential to generate detectable current density. The addition of $\mathrm{Ni}$ will enhance the generation of $\mathrm{OH}_{\text {ads }}$ at relatively negative potential, and therefore lower the onset potential of EOR. On the other hand, equation (5-10) indicates that the 'poisonous' $\mathrm{CH}_{3} \mathrm{CO}_{\text {ads }}$ or other intermediates can be removed by increasing the concentration of $\mathrm{OH}_{\text {ads. }}$. Thus, Ni will also serve to promote refreshing active Pd reactive sites, thus improving the overall reaction rate. Based on the above discussion, equation (5-10) on $\mathrm{Pd}_{\mathrm{x}} \mathrm{Ni}_{\mathrm{y}} / \mathrm{C}$ catalysts can be rewritten as:

$$
\mathrm{Pd}-\left(\mathrm{CH}_{3} \mathrm{CO}\right)_{a d s}+\mathrm{Ni}(\mathrm{OH})_{2}+\mathrm{OH}^{-} \longrightarrow \mathrm{Pd}-\mathrm{CH}_{3} \mathrm{COOH}+\mathrm{Ni}(\mathrm{OH})_{2}+e^{-}
$$

As discussed in the $\mathrm{CV}$ performance in $1.0 \mathrm{M} \mathrm{NaOH}$ solution, $\mathrm{Ni}$ species are more likely to be rich at the surface of organic solution phase reduction synthesized $\mathrm{Pd}_{\mathrm{x}} \mathrm{Ni}_{\mathrm{y}} / \mathrm{C}$ catalysts. Too much Ni will block part of the Pd active sites. Previous work by other groups has already demonstrated that $\mathrm{Ni}$ itself has no activity towards ethanol oxidation in alkaline solution in the potential range we investigated in this study. ${ }^{214}$ Too much $\mathrm{Ni}$ will reduce both the onset potential and MA due to the lack of Pd active sites. At the same time, excessive amount of $\mathrm{Ni}$ will increase the coverage of $\mathrm{OH}_{\mathrm{ads}}$ so much that the 
whole reaction is retarded by the insufficient supply of $\mathrm{CH}_{3} \mathrm{CO}_{\text {ads }}$. In this research, the lowest onset potential and the largest MA have been found on $\mathrm{Pd}_{4} \mathrm{Ni}_{5} / \mathrm{C}$ and $\mathrm{Pd}_{1} \mathrm{Ni}_{1} / \mathrm{C}$, respectively, indicating more efficient contacts or interactions between $\mathrm{Pd}$ and $\mathrm{Ni}$ species can be created through the organic solution phase reduction method.

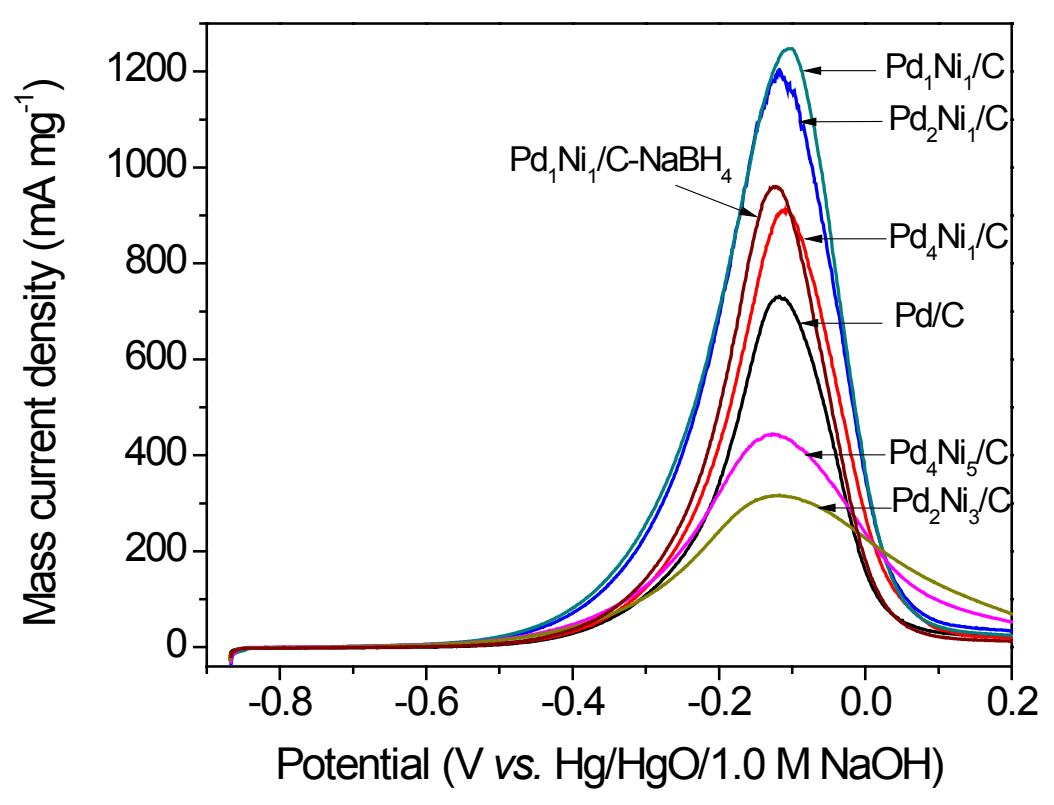

Fig. 5.7 Quasi-steady state linear scan voltammograms of ethanol oxidation reaction on $\mathrm{Pd} / \mathrm{C}$ and $\mathrm{Pd}_{\mathrm{x}} \mathrm{Ni}_{\mathrm{y}} / \mathrm{C}$ and $\mathrm{Pd}_{1} \mathrm{Ni}_{1} / \mathrm{C}-\mathrm{NaBH}_{4}$ catalysts $1.0 \mathrm{M} \mathrm{NaOH}+1.0 \mathrm{M} \mathrm{C}_{2} \mathrm{H}_{5} \mathrm{OH}$, at 1.0 $\mathrm{mV} / \mathrm{s}$, room temperature.

\section{Table 5.4}

Onset potential, Tafel slope and exchange current density of EOR on the $\mathrm{Pd} / \mathrm{C}, \mathrm{Pd}_{\mathrm{x}} \mathrm{Ni}_{\mathrm{y}} / \mathrm{C}$, and, $\mathrm{Pd}_{1} \mathrm{Ni}_{1} / \mathrm{C}$ catalysts (at room temperature).

\begin{tabular}{cccc}
\hline & $\begin{array}{c}\text { Onset potential } \\
(\mathrm{mV})\end{array}$ & $\begin{array}{c}\text { Tafel slope } \\
\left(\mathrm{V} \mathrm{dec}^{-1}\right)\end{array}$ & $\begin{array}{c}\text { Exchange current } \\
\text { density }\left(\times 10^{-9} \mathrm{~A} \mathrm{~cm}^{-2}\right)\end{array}$ \\
\hline $\mathrm{Pd} / \mathrm{C}$ & -621 & 0.13585 & 6.62 \\
$\mathrm{Pd}_{4} \mathrm{Ni}_{1} / \mathrm{C}$ & -718 & 0.15871 & 35.7 \\
$\mathrm{Pd}_{2} \mathrm{Ni}_{1} / \mathrm{C}$ & -758 & 0.17439 & 186 \\
$\mathrm{Pd}_{1} \mathrm{Ni}_{1} / \mathrm{C}$ & -769 & 0.17672 & 211 \\
$\mathrm{Pd}_{4} \mathrm{Ni}_{5} / \mathrm{C}$ & -801 & 0.21098 & 570 \\
$\mathrm{Pd}_{2} \mathrm{Ni}_{3} / \mathrm{C}$ & -750 & 0.21791 & 596 \\
$\mathrm{Pd}_{1} \mathrm{Ni}_{1} / \mathrm{C}-\mathrm{NaBH}_{4}$ & -669 & 0.14532 & 15.7
\end{tabular}


For the purpose of comparing the kinetic activities of $\mathrm{Pd} / \mathrm{C}, \mathrm{Pd}_{\mathrm{x}} \mathrm{Ni}_{\mathrm{y}} / \mathrm{C}$, and $\mathrm{Pd}_{1} \mathrm{Ni}_{1} / \mathrm{C}$ $\mathrm{NaBH}_{4}$ catalysts toward EOR, the Tafel plots were given in Fig. 5.8; the Tafel slopes and the exchange current densities are shown in Table 5.4. The Tafel plots investigation region is chosen from -0.55 to $-0.35 \mathrm{~V}$, which is because in this low potential range, the adsorption of $\mathrm{CH}_{3} \mathrm{CO}_{\mathrm{ad}}$ is independent of the potential and the kinetics of EOR is determined by the adsorption of $\mathrm{OH}^{-}$on the surface of electrode. ${ }^{205}$ The results summarized in Table 5.4 show the exchange current densities towards EOR on $\mathrm{Pd} / \mathrm{C}$ and $\mathrm{Pd}_{\mathrm{x}} \mathrm{Ni}_{\mathrm{y}} / \mathrm{C}$ catalysts follows the same trend of onset potential, with the highest exchange current density achieved on $\mathrm{Pd}_{2} \mathrm{Ni}_{3} / \mathrm{C}$ of $596 \times 10^{-9} \mathrm{~A} \mathrm{~cm}^{-2}$, which is 90 times higher than that of $\mathrm{Pd} / \mathrm{C}\left(6.62 \times 10^{-9} \mathrm{~A} \mathrm{~cm}^{-2}\right)$. The exchange current density on $\mathrm{Pd}_{1} \mathrm{Ni}_{1} / \mathrm{C}\left(221 \times 10^{-9}\right.$ $\mathrm{A} \mathrm{cm}{ }^{-2}$ ) is 33 times and 14 times higher than that of $\mathrm{Pd} / \mathrm{C}$ and $\mathrm{Pd}_{1} \mathrm{Ni}_{1} / \mathrm{C}-\mathrm{NaBH}_{4}$, respectively, indicating that a more efficient catalyst can be prepared through the present organic solution phase reduction method.

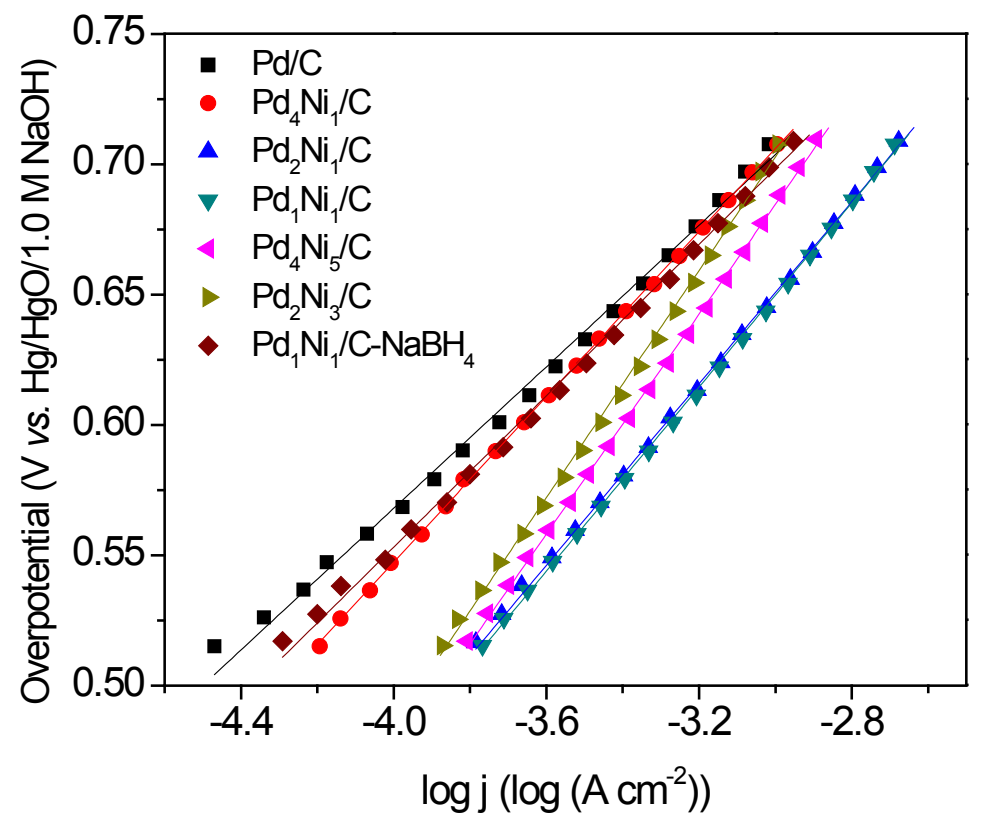

Fig. 5.8 Tafel plots for ethanol electro-oxidation on $\mathrm{Pd} / \mathrm{C}, \mathrm{Pd}_{\mathrm{x}} \mathrm{Ni} / \mathrm{C}$, and $\mathrm{Pd}_{1} \mathrm{Ni}_{1} / \mathrm{C}$ $\mathrm{NaBH}_{4}$ catalysts. 
The long-term reactivity of EOR on $\mathrm{Pd} / \mathrm{C}, \mathrm{Pd}_{\mathrm{x}} \mathrm{Ni}_{\mathrm{y}} / \mathrm{C}$, and $\mathrm{Pd}_{1} \mathrm{Ni}_{1} / \mathrm{C}-\mathrm{NaBH}_{4}$ catalysts have been investigated by chronoamperometry $(\mathrm{CA})$ in a $1.0 \mathrm{M} \mathrm{NaOH}+1.0 \mathrm{M} \mathrm{C}_{2} \mathrm{H}_{5} \mathrm{OH}$ solution, with an applied potential of $-0.5 \mathrm{~V}(v s . \mathrm{Hg} / \mathrm{HgO} / 1.0 \mathrm{M} \mathrm{NaOH})$, which is set in the low potential range of the Tafel study. Different from other groups which mainly studied the stability in a short period of $1800-3600$ seconds, ${ }^{188,198}$ the stability investigation in this work is focused on a longer term of $10000 \mathrm{~s}$. The mass activity time plots are shown in Fig. 5.9. The MA of all Pd-based catalysts at the end of CA and their corresponding mass activities at $-0.5 \mathrm{~V}$ in the quasi-steady-state linear sweep voltammetry curves are summarized in Table 5.5. To setup an evaluation criterion, we defined survival ratio as normalizing the MA after $10000 \mathrm{~s}$ CA test to their corresponding MA (at $-0.5 \mathrm{~V}$ ) in the quasi-steady-state linear sweep (at $1 \mathrm{mV} \mathrm{s}^{-1}$ ), and the results are also summarized in Table 5.5. The survival ratio indicates the ratio of active sites that remain the catalytic ability towards ethanol oxidation without being poisoned after the long-term reactivity test. The results clearly show a strong correlation between Pd-Ni contacts and long-term EOR reactivity. As shown in Fig. 5.9, Pd/C, which has no Ni, and $\mathrm{Pd}_{4} \mathrm{Ni}_{1} / \mathrm{C}$ which has little $\mathrm{Ni}$, were poisoned so heavily that their MAs dropped to $\sim 0 \mathrm{~mA}$ $\mathrm{mg}^{-1}$ at the end of CA test. On the other hand, the MA of $\mathrm{Pd}_{1} \mathrm{Ni}_{1} / \mathrm{C}-\mathrm{NaBH}_{4}$ also dropped to $\sim 0 \mathrm{~mA}$ because its less effective contact between Pd and Ni could not efficiently remove the 'poisonous intermediates' at such low applied potential. Therefore, after a long-term test, all the surface Pd active sites are poisoned. As shown in Table 5.5, the survival ratio on all the organic solution phase reduction method synthesized $\mathrm{Pd}_{\mathrm{x}} \mathrm{Ni}_{\mathrm{y}} / \mathrm{C}$ catalysts clearly shows a monotonically increasing relationship between the long-term EOR reactivity and $\mathrm{Ni}$ concentration. Meanwhile, it is worth noting that the current density will drop quickly in the first 500 seconds if the ratio of Pd to $\mathrm{Ni}$ is less than 1:1, which is probably caused by the lack of Pd active sites. As mentioned above, Ni will block the surface Pd active sites if there is an excessive $\mathrm{Ni}$ concentration using the present organic solution phase reduction method. Therefore, although it could increase its reaction stability, a higher concentration of $\mathrm{Ni}$ will reduce the total active sites and lower the overall EOR activity. 


\section{Table 5.5}

EOR mass activity (MA) at the end of 10000-second chronoamperometry, MA at- $0.5 \mathrm{~V}$ in quasi-steady-state linear sweep voltammetry $\left(1 \mathrm{mV} \mathrm{s}^{-1}\right)$ and survival ratio of $\mathrm{Pd} / \mathrm{C}$, $\mathrm{Pd}_{\mathrm{x}} \mathrm{Ni}_{\mathrm{y}} / \mathrm{C}$, and $\mathrm{Pd}_{1} \mathrm{Ni}_{1} / \mathrm{C}$ catalysts.

\begin{tabular}{cccc}
\hline & $\begin{array}{c}\text { MA at the end of } \\
10000 \text {-second } \mathrm{CA} \\
\left(\mathrm{mA} \mathrm{mg}^{-1}\right)\end{array}$ & $\begin{array}{c}\text { MA at }-0.5 \mathrm{~V} \text { in } \\
\text { quasi-steady state } \\
\text { polarization curve } \\
\left(\mathrm{mA} \mathrm{mg}^{-1}\right)\end{array}$ & $\begin{array}{c}\text { Survival } \\
\text { ratio } \\
(\%)\end{array}$ \\
\hline $\mathrm{Pd} / \mathrm{C}$ & $\sim 0$ & 5.17 & - \\
$\mathrm{Pd}_{4} \mathrm{Ni}_{1} / \mathrm{C}$ & $\sim 0$ & 7.46 & - \\
$\mathrm{Pd}_{2} \mathrm{Ni}_{1} / \mathrm{C}$ & 0.37 & 19.27 & 2 \\
$\mathrm{Pd}_{1} \mathrm{Ni}_{1} / \mathrm{C}$ & 1.33 & 21.89 & 6 \\
$\mathrm{Pd}_{4} \mathrm{Ni}_{5} / \mathrm{C}$ & 1.29 & 15.15 & 9 \\
$\mathrm{Pd}_{2} \mathrm{Ni}_{3} / \mathrm{C}$ & 1.71 & 14.49 & 12 \\
$\mathrm{Pd}_{1} \mathrm{Ni}_{1} / \mathrm{C}-\mathrm{NaBH}$ & 8.08 & - \\
\hline
\end{tabular}

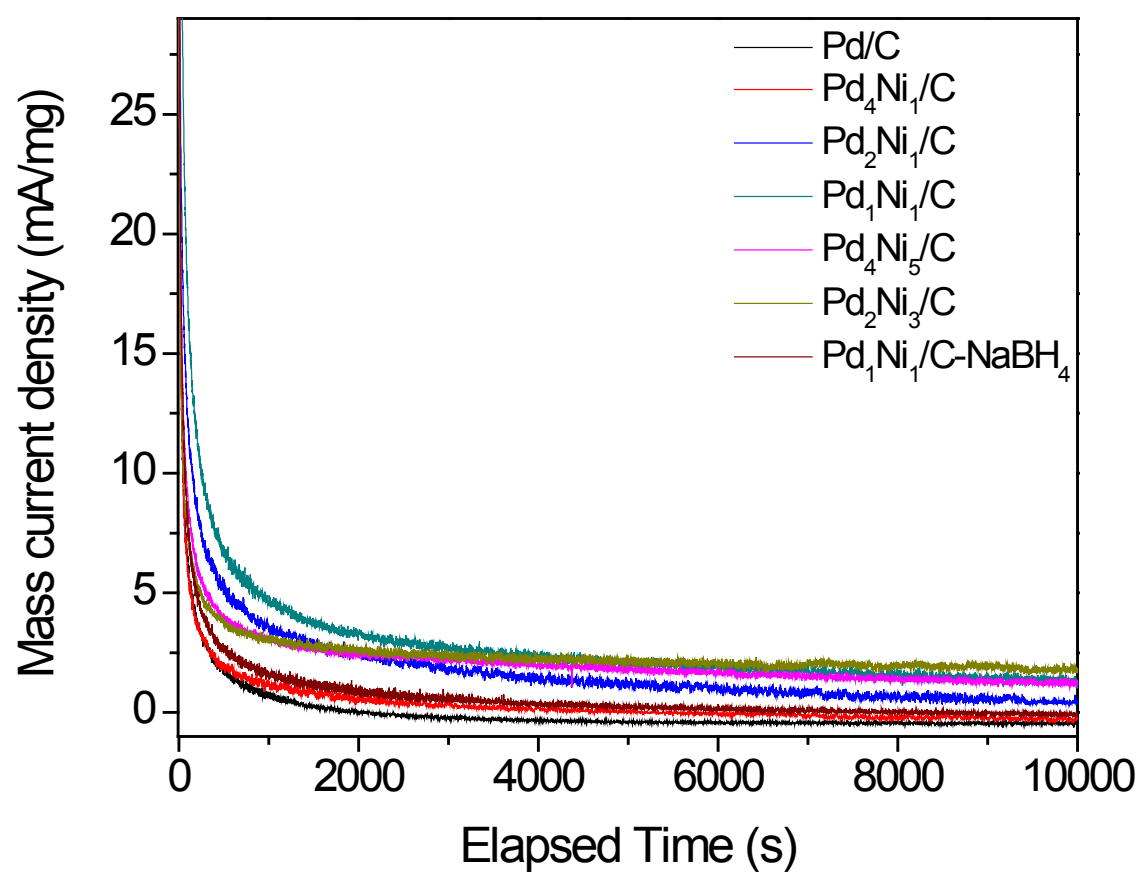

Fig. 5.9 Chronoamperometry curves on $\mathrm{Pd} / \mathrm{C}$ and $\mathrm{Pd}_{\mathrm{x}} \mathrm{Ni}_{\mathrm{y}} / \mathrm{C}$ and $\mathrm{Pd}_{1} \mathrm{Ni}_{1} / \mathrm{C}-\mathrm{NaBH}_{4}$ catalysts in $1.0 \mathrm{M} \mathrm{NaOH}+1 \mathrm{M} \mathrm{C}_{2} \mathrm{H}_{5} \mathrm{OH}$, at electrode potential of $-0.5 \mathrm{~V} v s$. $\mathrm{Hg} / \mathrm{HgO} / 1.0$ $\mathrm{M} \mathrm{NaOH}$ 


\subsection{Conclusion}

In summary, an organic solution phase reduction method has been developed to prepare $\mathrm{Pd}_{\mathrm{x}} \mathrm{Ni}_{\mathrm{y}} / \mathrm{C}$ catalysts with small diameters of $2.4-3.2 \mathrm{~nm}$, narrow size distributions of $1-6$ $\mathrm{nm}$, and large electro-chemical surface areas (i.e. $68.0 \mathrm{~m}^{2} \mathrm{~g}^{-1}$ for $\mathrm{Pd}_{4} \mathrm{Ni}_{1} / \mathrm{C}$ ). $\mathrm{The} \mathrm{Pd}_{\mathrm{x}} \mathrm{Ni}_{\mathrm{y}} / \mathrm{C}$ catalysts have demonstrated high reactivity towards ethanol oxidation reaction in alkaline electrolyte: i.e. the EOR onset potential on $\mathrm{Pd}_{4} \mathrm{Ni}_{5} / \mathrm{C}$ is $180 \mathrm{mV}$ more negative than that of $\mathrm{Pd} / \mathrm{C}$; the exchange current density of $\mathrm{Pd}_{2} \mathrm{Ni}_{3} / \mathrm{C}$ is 90 times higher than that of $\mathrm{Pd} / \mathrm{C}$. After a 10000 -second chronoamperometry test at $-0.5 \mathrm{~V}(v s . \mathrm{Hg} / \mathrm{HgO} / 1.0 \mathrm{M} \mathrm{KOH})$, the mass activity of $\mathrm{Pd}_{2} \mathrm{Ni}_{3} / \mathrm{C}$ survived at $1.71 \mathrm{~mA} \mathrm{mg}^{-1}$, while that of $\mathrm{Pd} / \mathrm{C}$ had dropped to 0 $\mathrm{mA} \mathrm{mg}{ }^{-1}$, which implies a better 'detoxification' ability of $\mathrm{Pd}_{\mathrm{x}} \mathrm{Ni}_{\mathrm{y}} / \mathrm{C}$ catalysts for a longterm ethanol oxidation reaction activity. We propose that surface Ni could serve to promote refreshing active $\mathrm{Pd}$ reactive sites, thus enhancing the overall ethanol oxidation kinetics. The organic solution phase reduction method has a better control over diameter and size distribution of Pd-Ni particles. This method is able to facilitate the formation of more efficient contacts between $\mathrm{Pd}$ and $\mathrm{Ni}$ at the surface, which is the key to improving the EOR activity. The small amount of surfactants was observed to have no apparent negative effects on ethanol oxidation reaction in alkaline electrolyte. 


\section{Chapter $6 \mathrm{Au} / \mathrm{C}$ as anode catalyst for anion- exchange membrane-direct glycerol fuel cell (AEM-DGFC)*}

\subsection{Introduction}

\subsubsection{Background}

The development of sustainable society needs wide-spread applications of renewable, reliable, and cost-effective energy technologies. ${ }^{3,227,228}$ Fuel cells (FCs) are considered a promising alternative electric power device to meet humanity's energy demands. Compared to $\mathrm{H}_{2}$-fed fuel cells, direct alcohol fuel cells (DAFCs) have attracted enormous attention due to the simple production, purification, and storage of the liquid fuels. ${ }^{36,117,168,169,184,229}$ Among all the alcohols, the electro-oxidation of methanol and ethanol have been widely investigated, ${ }^{61,169,184,192,194,195,229}$ due to their simple reaction mechanisms and relatively high volumetric energy density. (4.8 and $6.3 \mathrm{~kW} \mathrm{~h} \mathrm{~L}{ }^{-1}$, respectively, for complete oxidation to $\mathrm{CO}_{2}$ ) However, the toxicity of methanol and high volatility of ethanol, along with their low flash points remain critical issues under practical operation conditions. ${ }^{172}$ Glycerol is a non-toxic, non-volatile, and nonflammable highly functionalized molecule with a theoretical energy density of $6.3 \mathrm{~kW} \mathrm{~h}$ $\mathrm{L}^{-1}$. As a main byproduct of biodiesel production, glycerol is supplied in large quantities at low price. ${ }^{14}$ Therefore, glycerol is highly expected to be used in DAFCs as an inexpensive, renewable, and environmental-friendly fuel. ${ }^{230}$

\footnotetext{
*The material contained in this chapter was previously published in International Journal of Hydrogen Energy. Reprinted with permission from Journal of Hydrogen Energy 2012; 37(11), Zhiyong Zhang, Le Xin, and Wenzhen Li, "Supported gold nanoparticles as anode catalyst for anion-exchange membrane-direct glycerol fuel cell (AEM-DGFC)", 9393-9401. Copyright 2011 International Association for Hydrogen Energy.
} 


\subsubsection{Recent development of anion-exchange membrane direct glycerol fuel cells (AEM-DGFC)}

The investigations of glycerol oxidation in alkaline electrolytes in half cell studies started in 1980s. ${ }^{231,232}$ However, glycerol is treated seriously as a fuel only in recent years, thanks to the development of solid anion-exchange membrane and the blooming of biodiesel production. In half cells, the oxidation of glycerol in alkaline electrolyte was compared with that of methanol, ethanol, ethylene glycol, and 1,2-propanediol on different catalysts. It is found that on Pd-based catalysts, including Pd-NiO/C, ${ }^{194}$ $\mathrm{Pd} / \mathrm{MWCNT},{ }^{233}$ and $\mathrm{Pd} / \mathrm{TiO}_{2},{ }^{234}$ the glycerol oxidation suffers a higher onset potential than other small alcohols, although it can generate a higher peak current density. Different from $\mathrm{Pd}$, on polycrystalline $\mathrm{Au}$ electrode, glycerol has a better oxidation activity in terms of both onset potential and peak current density over other alcohols. ${ }^{235}$ Simoes et al compared the glycerol oxidation on Pt, Pd, Au, PdNi, and PdAu catalyst. It is reported that Pt possesses the lowest onset potential of $0.4 \mathrm{~V} v$ s. SHE, which is $0.15 \mathrm{~V}$ lower than that of $\mathrm{Pd}$ and $\mathrm{Au}$. In the meantime, it is also found that when alloyed together, the onset potential of PdAu catalyst negatively shifts about $0.1 \mathrm{~V}$ comparing to that of $\mathrm{Pd}$ and $\mathrm{Au}$ catalysts, while PdNi has little promotions. In anion-exchange membrane fuel cell (AEMFC) studies, Matsuoka et al. first used glycerol as fuel in a PtRu/C anode catalystbased AEMFC, and obtained a peak power density of $\sim 7 \mathrm{~mW} / \mathrm{cm}^{2}$ at $50^{\circ} \mathrm{C} .{ }^{236}$ Bianchini and co-workers achieved an AEM-DGFC performance of $\sim 118 \mathrm{~mW} / \mathrm{cm}^{2}$ on a Pd-(Ni-Zn$\mathrm{P}) / \mathrm{C}$ anode catalyst at $80^{\circ} \mathrm{C}^{184}$ Ilie et al optimized the membrane electrode assembly (MEA) fabrication method and reaction conditions (i.e. fuel composition, fuel flow rate, etc), and demonstrated an AEM-DGFC peak power density of $\sim 24 \mathrm{~mW} \mathrm{~cm}{ }^{-2}$ with $\mathrm{Pt}$ and Pt-based bimetallic anode catalysts at $60^{\circ} \mathrm{C} .{ }^{237}$ However, most of the previous AEMDGFC studies were focused on Pt- or Pd- based catalysts. Due to the high onset potential (0.55-0.65 V vs. SHE) of glycerol electro-oxidation observed on $\mathrm{Au}$ in half cell studies, ${ }^{72,216}$ it was assumed that a very high overpotential would be inevitably observed on $\mathrm{Au}$ anode catalyst, and thus the fuel cell performance is largely lowered. Therefore, little single cell performance has been reported on Au anode catalyst-based AEM-DGFCs. 


\subsubsection{Glycerol electro-oxidation mechanism in alkaline electrolyte}

From thermodynamic calculations, the fully oxidation of glycerol to $\mathrm{CO}_{2}$ will give a reversible potential of $1.230 \mathrm{~V}^{238}$

$$
\begin{gathered}
\mathrm{CH}_{2}(\mathrm{OH}) \mathrm{CH}(\mathrm{OH}) \mathrm{CH}_{2}(\mathrm{OH})+3.5 \mathrm{O}_{2} \longrightarrow 4 \mathrm{H}_{2} \mathrm{O}+3 \mathrm{CO}_{2} \\
E^{o}=1.230 \mathrm{~V} \text { vs. SHE }
\end{gathered}
$$

With the facilitation of $\mathrm{OH}^{-}$, the fully oxidation of glycerol to $\mathrm{CO}_{3}{ }^{2-}$ will lead to a reversible potential of $1.369 \mathrm{~V}$ :

$$
\begin{gathered}
\mathrm{CH}_{2}(\mathrm{OH}) \mathrm{CH}(\mathrm{OH}) \mathrm{CH}_{2}(\mathrm{OH})+6 \mathrm{OH}^{-}+\frac{7}{2} \mathrm{O}_{2} \rightarrow 3 \mathrm{CO}_{3}^{2-}+7 \mathrm{H}_{2} \mathrm{O} \\
E^{o}=1.369 \mathrm{~V} \text { vs. SHE }
\end{gathered}
$$

However, the real electro-oxidation of glycerol is a very complicated reaction that contains many possible reaction pathways and usually only partially oxidizes glycerol to more than ten kinds of $\mathrm{C}_{3}$ and $\mathrm{C}_{2}$ products. The complex reaction mechanism of glycerol oxidation makes it hard to maximize the fuel cell efficiency of AEM-DGFC. To obtain a better understanding of the glycerol electro-oxidation pathway, investigations have been performed using both in-situ Fourier transform infrared (FTIR) characterizations 216,239,240 and HPLC analyses, ${ }^{72-74}$ based on the half cell tests.

In situ FTIR is an important technique that can simultaneously monitor the reactive intermediates adsorbed on the surface of catalysts during electro-catalytic reactions. Therefore, it is widely used for reaction mechanism investigations. Based on the in situ FTIR study, Simoes proposed a simple reaction pathway of glycerol oxidation in alkaline electrolyte on carbon supported Pt, Pd, and Au catalysts, as shown in Fig. 6.1. Gomes, et al. also unambiguously identified tartronic acid and glyoxylic acid on both polycrystalline Pt and Au electrodes. ${ }^{240}$ In addition, mesoxalic aicd ${ }^{240}$ and $\mathrm{CO}_{2}{ }^{239}$ were also identified by in situ FTIR on polycrystalline Au electrode. Although the in situ FTIR is sensitive in monitoring the changes in organic functional groups, it is not accurate at quantitatively 
analyzing the concentration of each product. In addition, the information given by in situ FTIR is mainly related with the molecular structures on the surface of catalyst. Thus, it is weak in distinguishing stable products from reactive intermediates.

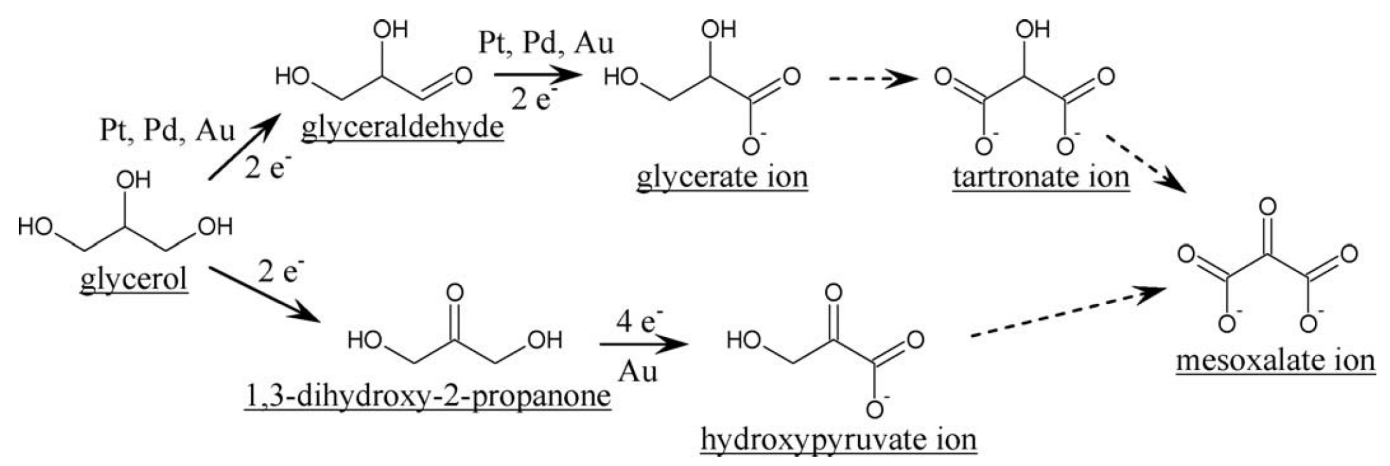

Fig. 6.1 Reaction mechanisms identified for $\mathrm{Pt} / \mathrm{C}, \mathrm{Pd} / \mathrm{C}$, and $\mathrm{Au} / \mathrm{C}$ for glycerol oxidation reaction. Dashed arrows correspond to a possible progress of the reaction ${ }^{216}$.

Comparing to FTIR, HPLC is a powerful technique for quantitative analysis of products concentration in bulk electrolyte. However, the HPLC analysis of each sample usually will take more than 15 minutes. The large gap in timescales between HPLC analysis and half cell voltammetries make it difficult to obtain the instant information of products concentrations in the course of voltammetry scans. By employing an elegant design of on-line collection off-line HPLC analysis instrument, Kwon et al. successfully collected the oxidation products at different potentials on $\mathrm{Pt}$ and $\mathrm{Au}$ polycrystalline electrodes, during a linear sweep voltammetry. Based on the changes of concentration of glycerol and its electro-oxidation products, a mechanism of glycerol oxidation on $\mathrm{Pt}$ and $\mathrm{Au}$ was proposed as shown in Fig. 6.2. Comparing to the in situ FTIR results, the HPLC analysis confirmed that glyceric acid, glycolic acid, and formic acid are bulkily formed on both Pt and $\mathrm{Au}$, while tartronic acid and oxalic acid are only largely produced on Pt. 


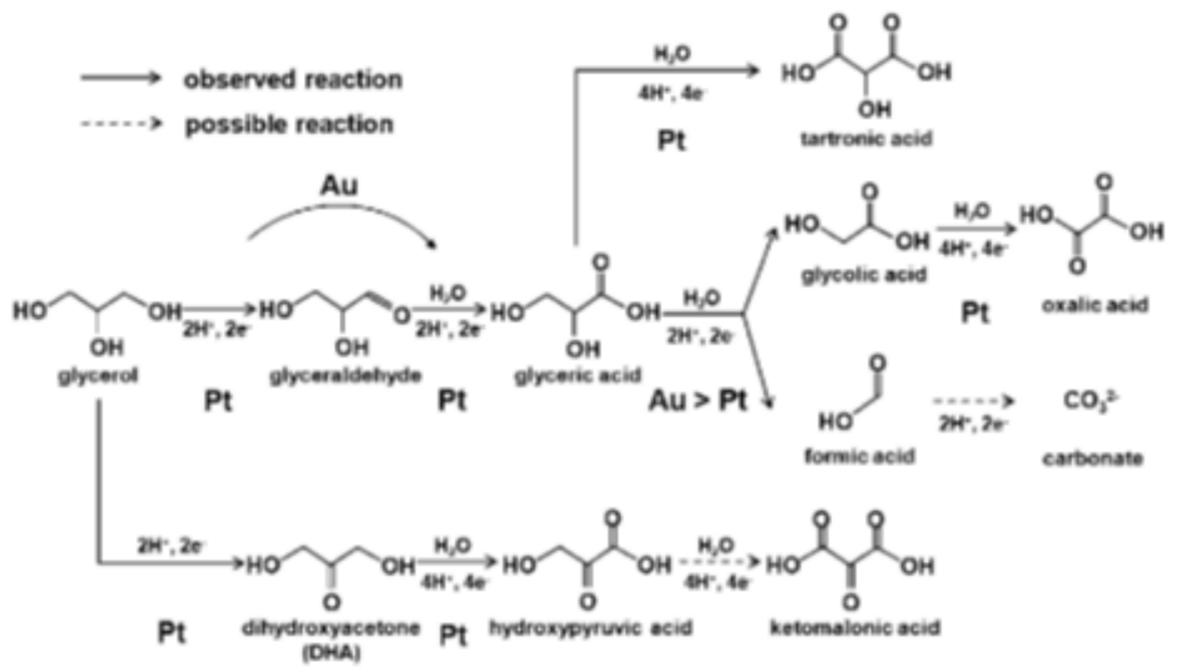

Fig. 6.2 The glycerol oxidation mechanism on Au and Pt electrodes in alkaline media ${ }^{74}$.

In this chapter, a carbon supported Au-NPs catalyst was prepared through the modified organic solution phase reduction method. ${ }^{208}$ The as-prepared $\mathrm{Au} / \mathrm{C}$ catalyst demonstrated a narrow particle size distribution of $2-6 \mathrm{~nm}$. The $\mathrm{Au} / \mathrm{C}$ catalyst was tested in a half cell, and further applied in an AEM-DGFC, demonstrating a high peak power density of 57.9 $\mathrm{mW} \mathrm{cm} \mathrm{cm}^{-2}$ at $80^{\circ} \mathrm{C}$. The AEM-DGFC with crude glycerol fuel under the same test conditions also achieved an OCV of $0.66 \mathrm{~V}$ and a peak power density of $30.7 \mathrm{~mW} \mathrm{~cm} \mathrm{~cm}^{-2}$. The product analysis reveals that in AEM-DGFC the $\mathrm{Au} / \mathrm{C}$ anode catalyst favors the production of deeper oxidized products, such as tartronate, mesoxalate, and oxalate. Based on the product distributions, the Faradic efficiency $\left(\eta_{\mathrm{e}}\right)$ of the AEM-DGFCs with the $\mathrm{Au} / \mathrm{C}$ anode catalyst was investigated.

\subsection{Experimental section}

\subsubsection{Preparation of $\mathrm{Au} / \mathrm{C}$ catalyst}

Au nanoparticles were synthesized through a modified organic solution phase reduction method. ${ }^{92,93,95,107,208,211,212} 0.5 \mathrm{mmol}$ of $\mathrm{AuCl}_{3}(151.7 \mathrm{mg})$ was dissolved in a mixture of 
$16 \mathrm{ml}$ of octadecene and $4 \mathrm{ml}$ of oleylamine under a nitrogen flow. The system was then rapidly heated to $80^{\circ} \mathrm{C}$, subsequently followed by a quick injection of $1.5 \mathrm{ml}$ of $\mathrm{LiBEt}_{3} \mathrm{H}$. After holding the temperature at $80^{\circ} \mathrm{C}$ for 10 minutes, the system was cooled down to room temperature and mixed with $100 \mathrm{ml}$ of carbon black-hexane ink (containing 229.8 $\mathrm{mg}$ of Vulcan XC-72R carbon black). $500 \mathrm{ml}$ of ethanol was then added in dropwisely to precipitate the $\mathrm{Au}$ particles out onto the carbon supports. The as-prepared $30 \mathrm{wt} \% \mathrm{Au} / \mathrm{C}$ catalyst was achieved after filtration, washed with copies of ethanol, and dried in vacuum oven at $50^{\circ} \mathrm{C}$ overnight.

\subsubsection{Physical characterizations}

The morphology, structure, and metal loading of $\mathrm{Au} / \mathrm{C}$ catalyst were analyzed by X-ray diffraction (XRD), transmission election microscopy (TEM), and inductively coupled plasma atomic emission spectroscopy (ICP-AES).

\subsubsection{Half cell test}

The half cell tests were performed by the procedure described in Section 2.3.1. $10 \mu$ of $0.05 \mathrm{wt} \%$ AS4 (Tokuyama) ionomer solution was applied as the ionomer to fix the catalyst. The ECSA was evaluated based on the reduction peak of a monolayer of gold oxide in the polarization curve of a $\mathrm{CV}$ scan in $1.0 \mathrm{M} \mathrm{KOH}$, using equation (2-3):

$$
S_{e}=\frac{Q_{r}}{m \times C}
$$

while the charge density $\mathrm{C}$ is chosen as $0.386 \mathrm{mC} \mathrm{cm}^{-2}$ based on reference $\mathrm{e}^{241}$.

The activity of glycerol electro-oxidation was investigated by a CV scan in $2.0 \mathrm{M} \mathrm{KOH}+$ $0.05 \mathrm{M}$ glycerol, and was compared with that of methanol and EG under the same test condition. In order to further optimize the effects of alkaline and glycerol concentrations, linear scan voltammetry (LSV) was carried out in different concentrations of $\mathrm{KOH}$ and 
glycerol from $-0.9-0.8 \mathrm{~V}$, with a sweep rate of $1 \mathrm{mV} \mathrm{s}^{-1}$ and a rotation speed of 2,500 rpm.

\subsubsection{AEM-DGFC test}

A MEA with a $\mathrm{Au}$ anode $\left(1.0 \mathrm{mg}_{\mathrm{Au}} \mathrm{cm}^{-2}\right)$, an AS-4 anion-exchange ionomer, non-Pt group metal (PGM) HYPERMECTM cathode $\left(1 \mathrm{mg}_{\text {catalyst. }} \mathrm{cm}^{-2}\right)$ was prepared by the procedure in Section 2.4.2.1. The performance of AEM-DGFC was evaluated with a 2.0 $\mathrm{M} \mathrm{KOH}+1.0 \mathrm{M}$ glycerol solution and high purity $\mathrm{O}_{2}(99.999 \%)$ at the fuel cell working temperature from 50 to $80^{\circ} \mathrm{C}$. Serving as control experiments, a proton-exchange membrane - direct glycerol fuel cell (PEM-DGFC) performance was collected at $90^{\circ} \mathrm{C}$, fed with $1.0 \mathrm{M}$ glycerol solution. The MEA employed in the PEM-DGFC was assembled with a PtRu/C-based anode ( $\left.4.0 \mathrm{mg}_{\mathrm{PtRu}} \mathrm{cm}^{-2}\right)$, Nafion $115 \mathrm{membrane}$, and a Pt/C-based cathode $\left(4.0 \mathrm{mg}_{\mathrm{Pt}} \mathrm{cm}^{-2}\right)$. The performances of AEMFCs fed with $2.0 \mathrm{M} \mathrm{KOH}+1.0 \mathrm{M}$ methanol (or EG) were also investigated at $80^{\circ} \mathrm{C}$ for comparison. In order to examine the performance of biomass-derived crude glycerol in $\mathrm{Au} / \mathrm{C}$ anode catalyst-based AEMDGFC, $2.0 \mathrm{M} \mathrm{KOH}+1.0 \mathrm{M}$ crude glycerol was applied as fuel at $80^{\circ} \mathrm{C}$. The durability of $\mathrm{Au} / \mathrm{C}$ anode $\mathrm{AEM}-\mathrm{DGFC}$ fed with crude glycerol was studied by 100 continuous runs of polarization scans under the same test conditions, while the cathode catalyst loading was increased to $2.0 \mathrm{mg} \mathrm{cm}^{-2}$ to minimize the effect of cathode catalyst activity loss.

\subsubsection{Faradic efficiency analysis and product analysis}

The glycerol electro-oxidation products on $\mathrm{Au} / \mathrm{C}$ anode catalyst in AEM-DGFC and the fuel cell's Faradic efficiency were with a $2.0 \mathrm{M} \mathrm{KOH}+1.0 \mathrm{M}$ glycerol solution, following the procedure in Section 2.4.2.3, with a constant cell voltage of 0.5, 0.3, or 0.1 $\mathrm{V}$ applied for 2 hours at $50^{\circ} \mathrm{C}$. The selectivity (S) to each product was calculated by equation (2-9): 


$$
\text { Selectivity }=\frac{\text { Moles of specific product forms }}{\text { Total moles of } C_{2} \text { and } C_{3} \text { products detected }} \times 100 \%
$$

Based on the product distributions, the Faradic efficiency $\left(\eta_{\mathrm{e}}\right)$ was calculated by using the equation (2-10):

$$
\eta_{e}=\sum S_{i} \bullet \eta_{e_{i}}
$$

\subsection{Results and discussion}

\subsubsection{Physical characterizations}

The XRD pattern of $\mathrm{Au} / \mathrm{C}$ catalyst is shown in Fig. 6.3, which presents a typical $\mathrm{Au}$ face centered cubic (FCC) structure (JCPDS card 4-784). The average Au crystal size calculated based on the $\mathrm{Au}$ (220) diffraction peak is $3.4 \mathrm{~nm}$, using the Debye-Scherer formula (equation (2-1)):

$$
L=\frac{0.9 \lambda_{K \alpha}}{B_{2 \theta} \cos \theta_{\max }}
$$

A typical TEM image of $\mathrm{Au} / \mathrm{C}$ is shown in Fig. 6.4 (a). It is evidenced that most Au-NPs are round and uniformly dispersed on the carbon support with only a few agglomerations. The Au average particle size measured from the TEM image is $3.5 \mathrm{~nm}$, showing a good agreement with the XRD result. The histogram of particle sizes evaluated from over 100 particles in an arbitrarily chosen area is shown in Fig. 6.4 (b) which suggests a narrow size distribution of $2-6 \mathrm{~nm}$. The metal loading determined by ICP-AES is $30.8 \mathrm{wt} \%$, indicating all the $\mathrm{Au}$ precursor was fully reduced and deposited on the carbon support. Compared to previous studies, ${ }^{46,242,243}$ the self-prepared $\mathrm{Au} / \mathrm{C}$ catalyst exhibits a smaller diameter and a more narrow size distribution, indicating that the organic solution phase reduction method has a better morphology control capability on Au, even with a high metal loading of $30 \mathrm{wt} \%$. 


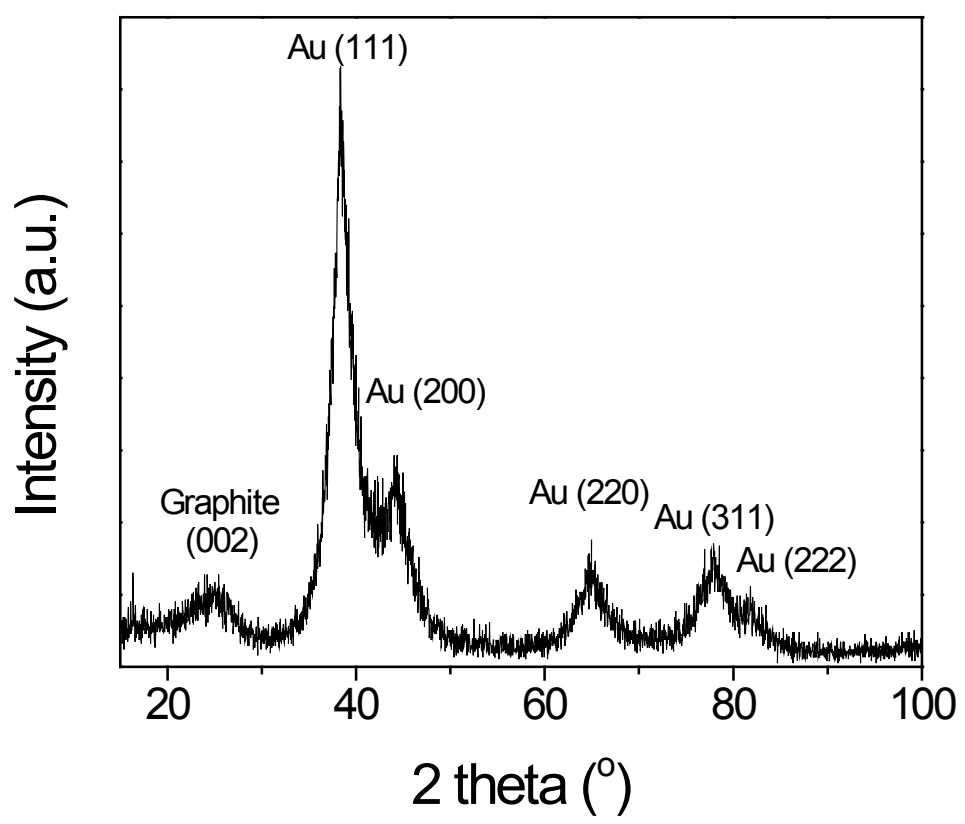

Fig. 6.3 The XRD pattern of $\mathrm{Au} / \mathrm{C}$ catalyst.
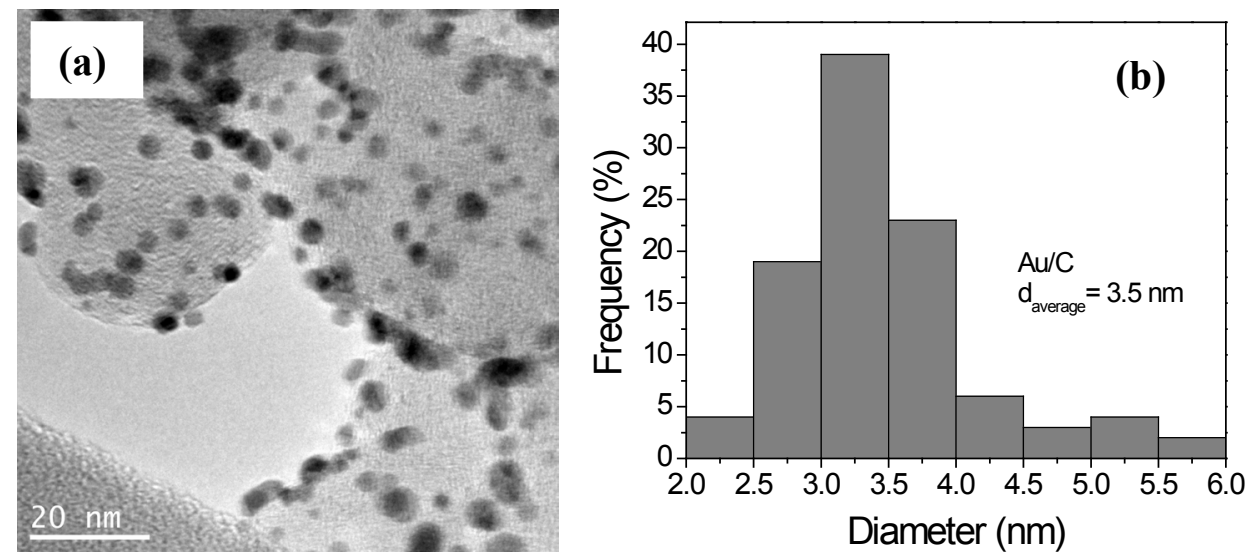

Fig. 6.4 TEM image (a), and particle size histogram (b) of $\mathrm{Au} / \mathrm{C}$.

\subsubsection{Electro-chemical studies in half cell}

In order to obtain the ECSA of the as-prepared $\mathrm{Au} / \mathrm{C}$ catalyst, a 10-cycle $\mathrm{CV}$ scan was performed in $1.0 \mathrm{M} \mathrm{KOH}$ from $-0.9-0.7 \mathrm{~V}$ at $50 \mathrm{mV} \mathrm{s}^{-1}$, and the last cycle is shown in Fig. 6.5 (a). The anodic peak on the forward scan and the cathodic peak on the backward scan are assigned to the formation and reduction of a monolayer of $\mathrm{Au}$ oxide. ${ }^{241} \mathrm{The}$ 
ECSA of Au/C catalyst is $26.8 \mathrm{~m}^{2} \mathrm{~g}^{-1}$, which was evaluated from the reduction peak at $0.13 \mathrm{~V}$ with a double layer correction and a charge density of $0.386 \mathrm{mC} \mathrm{cm}^{-2} .241$

The electro-catalytic oxidation of glycerol in alkaline media on $\mathrm{Au} / \mathrm{C}$ was investigated in 1.0 M KOH + 0.05 M glycerol, and was compared with that of methanol and ethylene glycol (EG) under the same condition. As shown in Fig. 6.5 (b), the shape of CV curves of both EG and glycerol oxidation represents the typical electro-oxidation reaction of alcohols, with two well-defined anodic peaks in forward and backward scans. However, the electro-oxidation of methanol is weak on $\mathrm{Au} / \mathrm{C}$. It is noted that the glycerol oxidation current is less stable than EG oxidation current in range of $0.16-0.3 \mathrm{~V}$. Some authors have attributed this instability to the complex electro-oxidation kinetics. ${ }^{216}$ However, taking into consideration the accelerated reaction rate at this area, it is possible that the fluctuation in current is due to the diffusion issues rising from the fast consumption of glycerol and $\mathrm{KOH}$. Compared to EG and methanol, glycerol possesses a higher activity on $\mathrm{Au} / \mathrm{C}$ catalyst, with both a lower onset potential and higher electro-oxidation currents in the whole investigated potential range. Based on the base catalysis theory, the first deprotonation of $\mathrm{H}_{\alpha}$ in alcohol on Au catalyst is base catalyzed: ${ }^{73}$

$$
\mathrm{H}_{\beta} \mathrm{R}-\mathrm{OH}_{\alpha}+\mathrm{OH}^{-} \rightleftarrows \mathrm{H}_{\beta} \mathrm{R}-\mathrm{O}^{-}+\mathrm{H}_{2} \mathrm{O}
$$

The reaction produces highly reactive alkoxide and follows a Hammett type correlation with the $\mathrm{pK}_{\mathrm{a}}$ of alcohol. Therefore, a lower $\mathrm{pK}_{\mathrm{a}}$ of alcohol will lead to a higher reactivity. As the $\mathrm{pK}_{\mathrm{a}}$ of glycerol is 14.15 , which is lower than that of EG (14.77) and methanol (15.50), it is easier for glycerol to deprotonate into highly reactive glycerolate in high $\mathrm{pH}$ media, resulting in a high overall electro-oxidation activity. Therefore, glycerol is expected to be a promising fuel for Au anode catalyst-based AEM-DGFC.

The effect of alkaline concentration on glycerol electro-oxidation was further investigated through linear voltammetry scans with $0.05 \mathrm{M}$ glycerol, and the results are shown in Fig. 6.5 (c). It is reasonable to consider that the glycerol oxidation on the $\mathrm{Au} / \mathrm{C}$ undergoes a quasi-steady state with negligible mass transfer issue, due to the adopted slow scan rate 
of $1 \mathrm{mVs}^{-1}$ and high electrode rotation speed of 2,500 rpm. With the $\mathrm{KOH}$ concentration increasing, the onset potential of glycerol oxidation shifts negatively, with the value of $0.271,-0.274$, and $-0.374 \mathrm{~V}$ in $0.1,1.0$, and $2.0 \mathrm{M} \mathrm{KOH}$, respectively. It was reported that high $\mathrm{pH}$ will benefit the initial deprotonation of glycerol. ${ }^{75,244}$ Therefore, high $\mathrm{OH}^{-}$ concentration will promote the generation of highly reactive glycerolate through a simple base catalyzed pathway in the electrolyte. ${ }^{73}$ Meanwhile, the recent investigation in DFT calculations also suggests that in an alkaline environment, the adsorbed $\mathrm{OH}_{\mathrm{ad}}$ will enhance the elimination of both $\mathrm{H}_{\alpha}$ and $\mathrm{H}_{\beta}$ of adsorbed alcohols on the Au surface through a metal surface catalyzed process by lowing the activation energy barriers,${ }^{76}$, as shown in equation (6-4) and (6-5), respectively:

$$
\begin{gathered}
H_{\beta} R-\mathrm{OH}_{\alpha, a d}+\mathrm{OH}_{a d} \rightarrow \mathrm{H}_{\beta} R-\mathrm{O}_{a d}+\mathrm{H}_{2} \mathrm{O} \\
\mathrm{H}_{\beta} R-\mathrm{O}_{a d}+\mathrm{OH}_{a d} \rightarrow R=\mathrm{O}_{a d}+\mathrm{H}_{2} \mathrm{O}
\end{gathered}
$$

The higher $\mathrm{pH}$ will increase the $\mathrm{OH}_{\mathrm{ad}}$ coverage rate on the $\mathrm{Au}$ surface and facilitate glycerol electro-oxidation. Also, according to the bi-functional theory, oxidation of primary alcohol requires adsorbed $\mathrm{OH}$ on the catalyst surface to decrease the onset potential, ${ }^{216}$ which will take advantage of high $\mathrm{pH}$ electrolytes. ${ }^{27}$ When the concentration of $\mathrm{KOH}$ further increases to $3.0 \mathrm{M}$, the onset potential shifts positively to $-0.354 \mathrm{~V}$. This is probably because too much $\mathrm{OH}_{\mathrm{ad}}$ on the Au catalyst surface blocks the glycerol adsorption, resulting in a lower reactivity. The $\mathrm{OH}^{-}$concentration also affects the peak current and peak potential. In the case of $\mathrm{KOH}>1.0 \mathrm{M}$, it has been found that the high $\mathrm{OH}_{\mathrm{ad}}$ coverage ratio leads to an insufficient glycerol and/or alkoxy adsorption, which further results in a lower current density. In the meantime, it is noted that the peak potential shifts to the negative direction with $\mathrm{OH}^{-}$concentration increasing. Although this peak shift was assigned by some authors to be an enhancement of glycerol oxidation reactivity, ${ }^{216}$ previous studies of surface Au oxidation in alkaline electrolyte revealed that the sharp decrease in the oxidation currents was due to the formation of a well-developed gold oxide layer. ${ }^{239,245}$ Therefore, the peak shifting indicates that a high $\mathrm{OH}_{\mathrm{ad}}$ coverage rate will enhance the generation of a fully developed $\mathrm{Au}$ oxide layer at the catalyst surface. 
Fig. 6.5 (d) shows the electrooxidation curves of different concentration of glycerol in 2.0 $\mathrm{M} \mathrm{KOH}$. With the glycerol concentration increasing, the onset potential gradually shifts to the negative direction, with the value of $-0.374,-0410,-0.460$ and $-0.480 \mathrm{~V}$ for $0.05,0.1,0.5$ and 1.0 M glycerol, respectively. As glycerol is a weak acid with a $\mathrm{pKa}=$ 14.15, higher glycerol concentration will generate more highly reactive glycerolate, that will further improve the onset potential. With the glycerol concentration increasing, the peak position moves monotonically to the positive direction, leading to higher peak currents. Higher initial glycerol concentration can lead to higher alkoxy or other intermediates adsorbed on the $\mathrm{Au}$ surface, which will reduce the $\mathrm{OH}_{\mathrm{ad}}$ coverage ratio, therefore, delay the formation of gold oxide layer on the catalyst surface. On the other hand, some intermediates, ie, alkoxy and aldehyde, with high reducing activity, could 'protect' the surface Au from being oxidized and losing reactivity. 1.0 M glycerol is such a high concentration that no peak current could be found in the whole investigated potential range. 

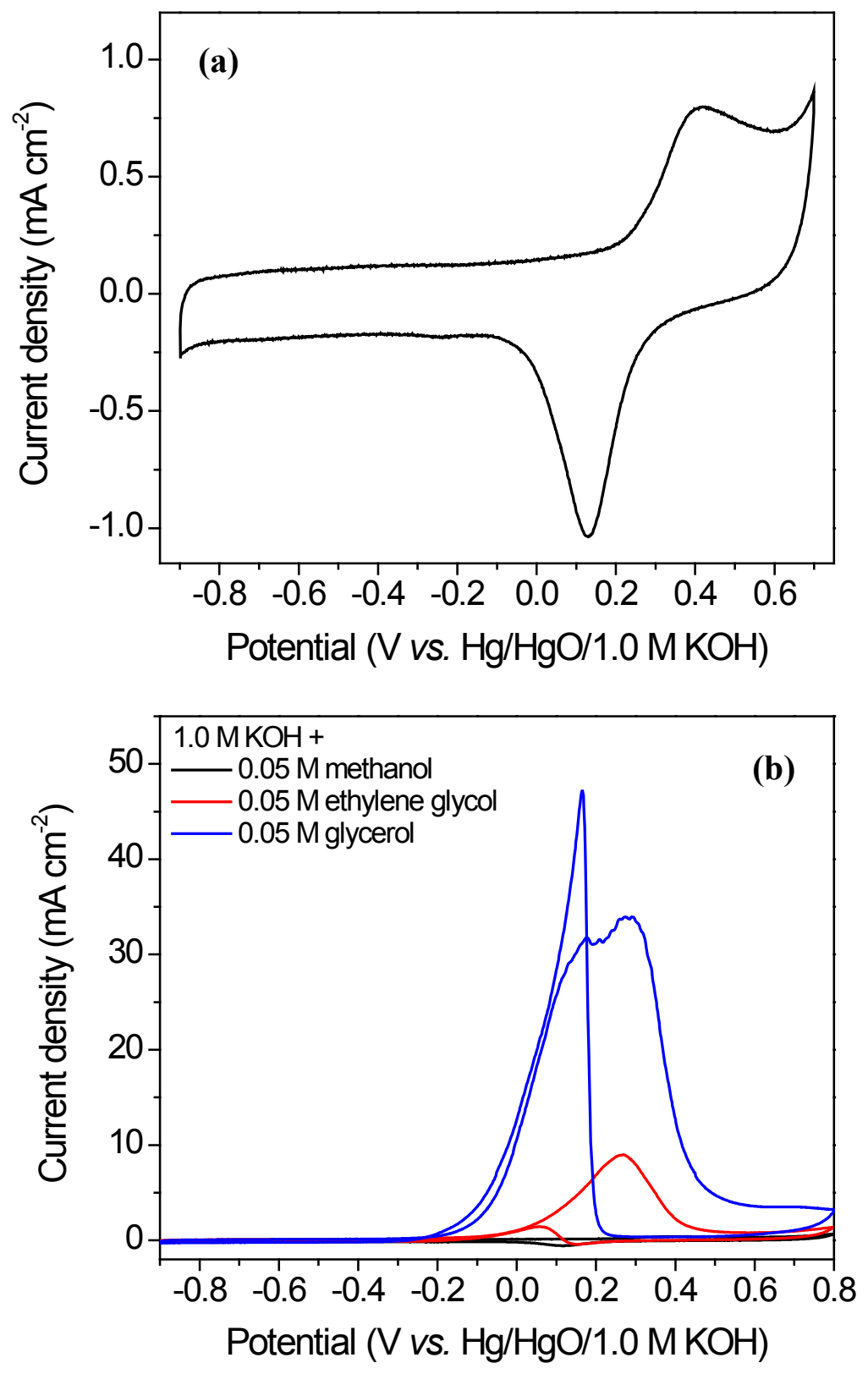

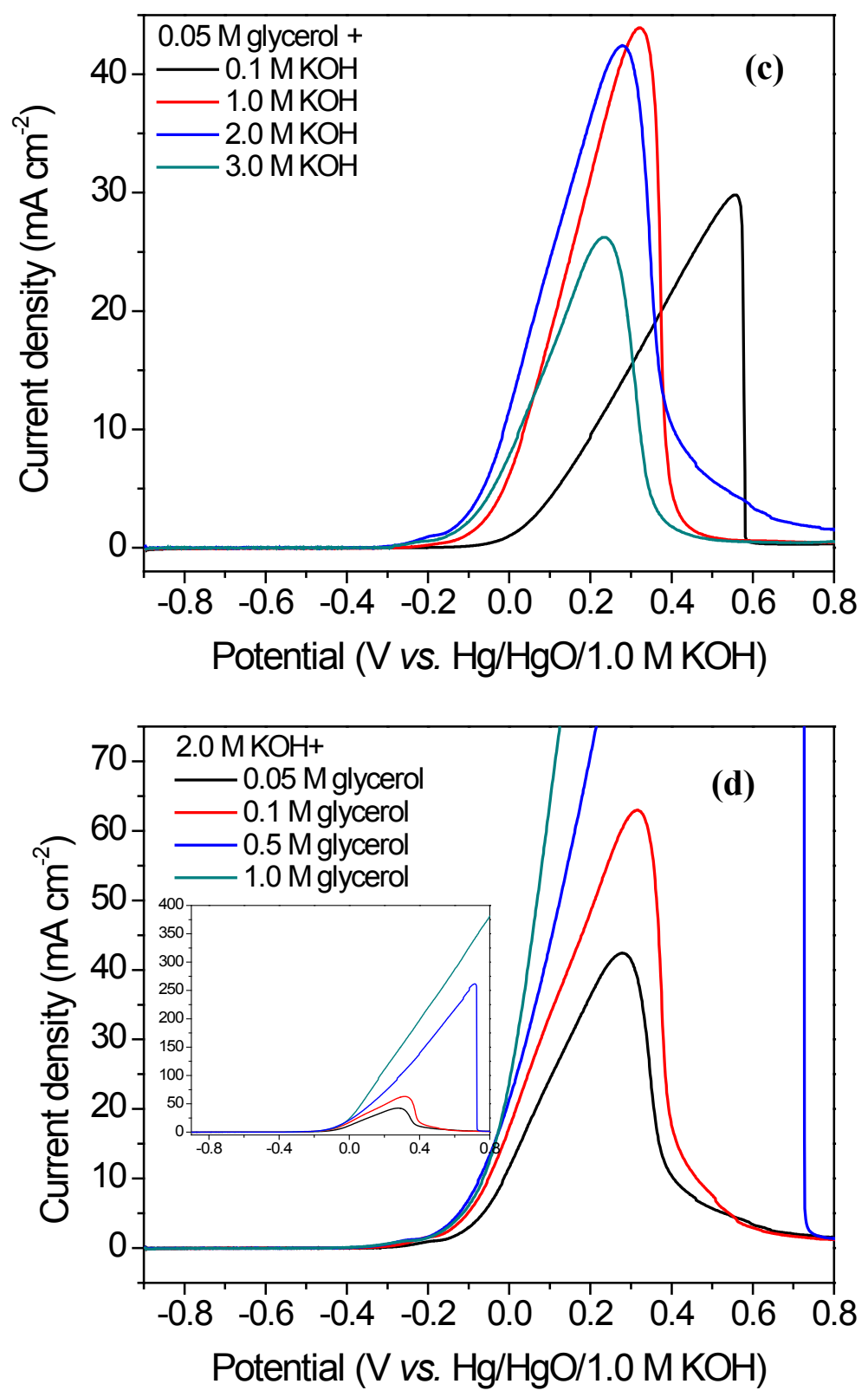

Fig. 6.5 Cyclic voltammograms of $\mathrm{Au} / \mathrm{C}$ in $1.0 \mathrm{M} \mathrm{KOH}, 50 \mathrm{mV} \mathrm{s}^{-1}$ (a), $1.0 \mathrm{M} \mathrm{KOH}+$

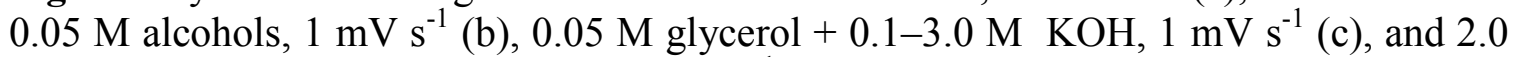
$\mathrm{M} \mathrm{KOH}+0.05 \mathrm{M} \sim 1.0 \mathrm{M}$ glycerol, $1 \mathrm{mV} \mathrm{s}^{-1}$, the inserted zooming out current in y-axis (d), at room temperature. 


\subsubsection{AEM-DGFC studies}

The as-prepared $\mathrm{Au} / \mathrm{C}$ was applied as the anode catalyst for an AEM-DGFC, and demonstrated high electricity generation performance. As shown in Fig. 6.6 (a), when fed with $2.0 \mathrm{M} \mathrm{KOH}+1.0 \mathrm{M}$ glycerol, the AEM-DGFC with a loading of $1.0 \mathrm{mg}_{\mathrm{Au}} \mathrm{cm}^{-2}$ produced an open circuit voltage $(\mathrm{OCV})$ of $0.59 \mathrm{~V}$ and a peak power density of $17.5 \mathrm{~mW}$ $\mathrm{cm}^{-2}$ at $110 \mathrm{~mA} \mathrm{~cm}{ }^{-2}$ at $50^{\circ} \mathrm{C}$. The performance was significantly improved with the temperature increasing. At higher temperatures of 60 and $70^{\circ} \mathrm{C}$, the $\mathrm{OCV}$ and peak power density reached $0.63 \mathrm{~V}$ and $26.3 \mathrm{~mW} \mathrm{~cm}{ }^{-2}$ (at $130 \mathrm{~mA} \mathrm{~cm}^{-2}$ ), and $0.65 \mathrm{~V}$ and $37.1 \mathrm{~mW}$ $\mathrm{cm}^{-2}$ (at $190 \mathrm{~mA} \mathrm{~cm}^{-2}$ ), respectively. When the temperature further increased to $80^{\circ} \mathrm{C}$, the OCV achieved at $0.67 \mathrm{~V}$, while the peak power density reached $57.9 \mathrm{~mW} \mathrm{~cm}{ }^{-2}$. In addition, as the operation temperature was increased, the slope of I-V curve became less negative at the electro-chemical kinetics-controlled low current density region (i.e. 0-50 $\mathrm{mA} \mathrm{cm}{ }^{-2}$ ), indicating the glycerol oxidation kinetics were greatly enhanced at higher temperatures. It is also demonstrated in Fig. 6.6 (a) that the mass transport limiting currents increased from $210 \mathrm{~mA} \mathrm{~cm}{ }^{-2}\left(50^{\circ} \mathrm{C}\right)$ to $389 \mathrm{~mA} \mathrm{~cm}^{-2}\left(80^{\circ} \mathrm{C}\right)$, indicating that better reactant diffusion may be achieved at higher temperatures. The output power density observed in the $\mathrm{Au} / \mathrm{C}$ anode catalyst-based AEM-DGFC is $1-2$ orders higher than the state-of-art biofuel cells with glycerol fuel (normally $<1.0 \mathrm{~mW} \mathrm{~cm}{ }^{-2}$ ). ${ }^{246,247}$ It is also much higher than the performance of PtRu/C anode catalyst-based $\left(2.6 \mathrm{mWcm}^{-2}\right.$ on $5.0 \mathrm{mg}_{\mathrm{PtRu}} \mathrm{cm}^{-2}$ ) proton-exchange membrane-direct glycerol fuel cell (PEM-DGFC). The promising performance of this AEM-DGFC may be attributed to the small $\mathrm{Au}$ nanoparticles $(2-6 \mathrm{~nm})$, which offers a high active surface area, and increased number of Au atoms with higher intrinsic activity at the edge..$^{18,244,248}$

The behavior of AEM-DGFC is also compared with that of AEMFCs fed with methanol and EG under the same test conditions at $80^{\circ} \mathrm{C}$, as shown in Fig. 6.6 (b). When fed with 2.0 M KOH $+1.0 \mathrm{M}$ methanol, the AEMFC only yielded an OCV of $0.29 \mathrm{~V}$ and a peak power density of $0.8 \mathrm{~mW} \mathrm{~cm}^{-2}$ (at $8 \mathrm{~mA} \mathrm{~cm}^{-2}$ ). With the number of hydroxymethyl groups in the fuel molecules increasing, the OCV and peak power density increased significantly: 
$0.58 \mathrm{~V}$ and $20.3 \mathrm{~mW} \mathrm{~cm}{ }^{-2}$ for $1.0 \mathrm{M} \mathrm{EG}$, and $0.67 \mathrm{~V}$ and $57.9 \mathrm{~mW} \mathrm{~cm}{ }^{-2}$ for $1.0 \mathrm{M}$ glycerol. At the same time, the better oxidation kinetics of alcohols with more hydroxymethyl groups are also evidenced by the increase of limiting current, as well as the less steep slope of I-V curve at low current density region. The AEMFC performances with different alcohols are in good agreement with the half cell test results, with the reactivity sequence of glycerol $>$ EG $>$ methanol.

A commercial crude glycerol was directly employed as fuel for the $\mathrm{Au} / \mathrm{C}$ anode catalystbased AEM-DGFC, which demonstrated reasonably high performance at $80^{\circ} \mathrm{C}$. The crude glycerol contains 88.05 wt.\% of glycerol, $5.42 \mathrm{wt} . \%$ of matter organic non glycerol (MONG), 4.16 wt.\% of moisture, 2.37 wt.\% of ash, and $628 \mathrm{ppm}$ of methanol, and was used as purchased without any further treatment. As shown in Fig. 6.6 (c), when fed with $2.0 \mathrm{M} \mathrm{KOH}+1.0 \mathrm{M}$ crude glycerol, the OCV and peak power density of the AEMDGFC reached $0.66 \mathrm{~V}$ and $30.7 \mathrm{~mW} \mathrm{~cm}^{-2}$ (at $140 \mathrm{~mA} \mathrm{~cm}$ ) at $80^{\circ} \mathrm{C}$. The fuel cell performance with crude glycerol is comparable to that with high-purity glycerol $(0.67 \mathrm{~V}$ and $\left.57.9 \mathrm{~mW} \mathrm{~cm}^{-2}\right)$ and higher than that with high-purity EG $(0.58 \mathrm{~V}$ and $20.3 \mathrm{~mW} \mathrm{~cm}$ ). This indicates that $\mathrm{Au} / \mathrm{C}$ is able to serve as a highly active anode catalyst for electrooxidation of biomass-derived crude glycerol in AEM-DGFC, without being significantly poisoned by the impurities.

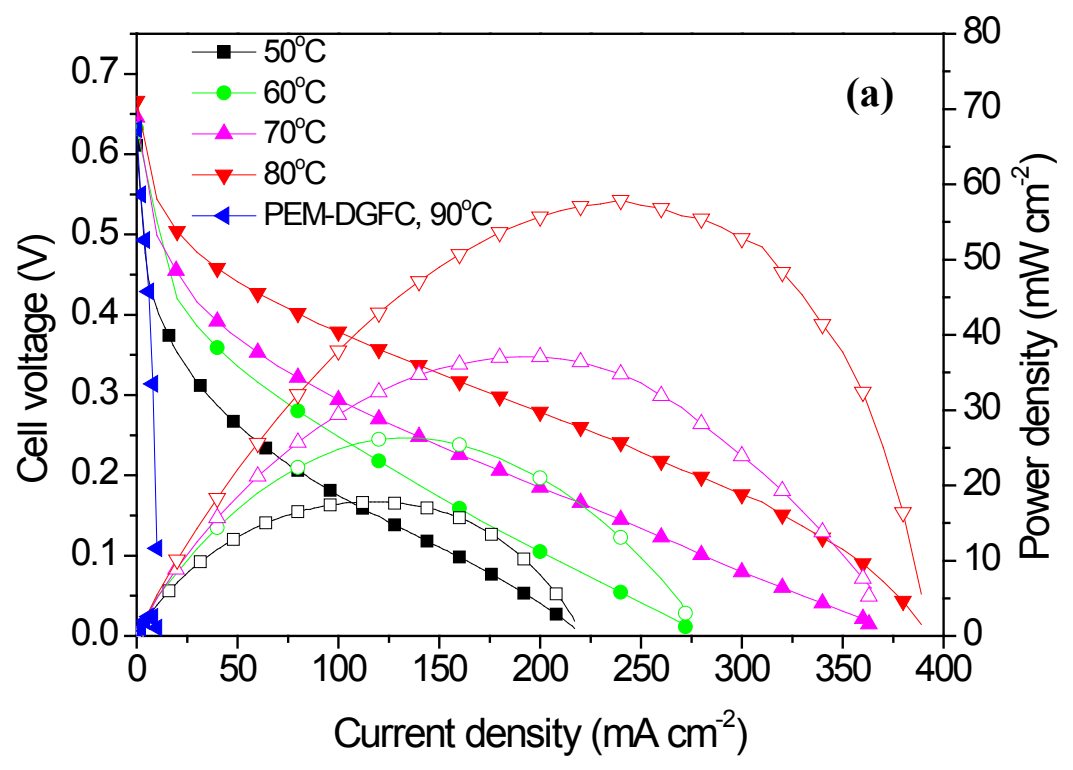



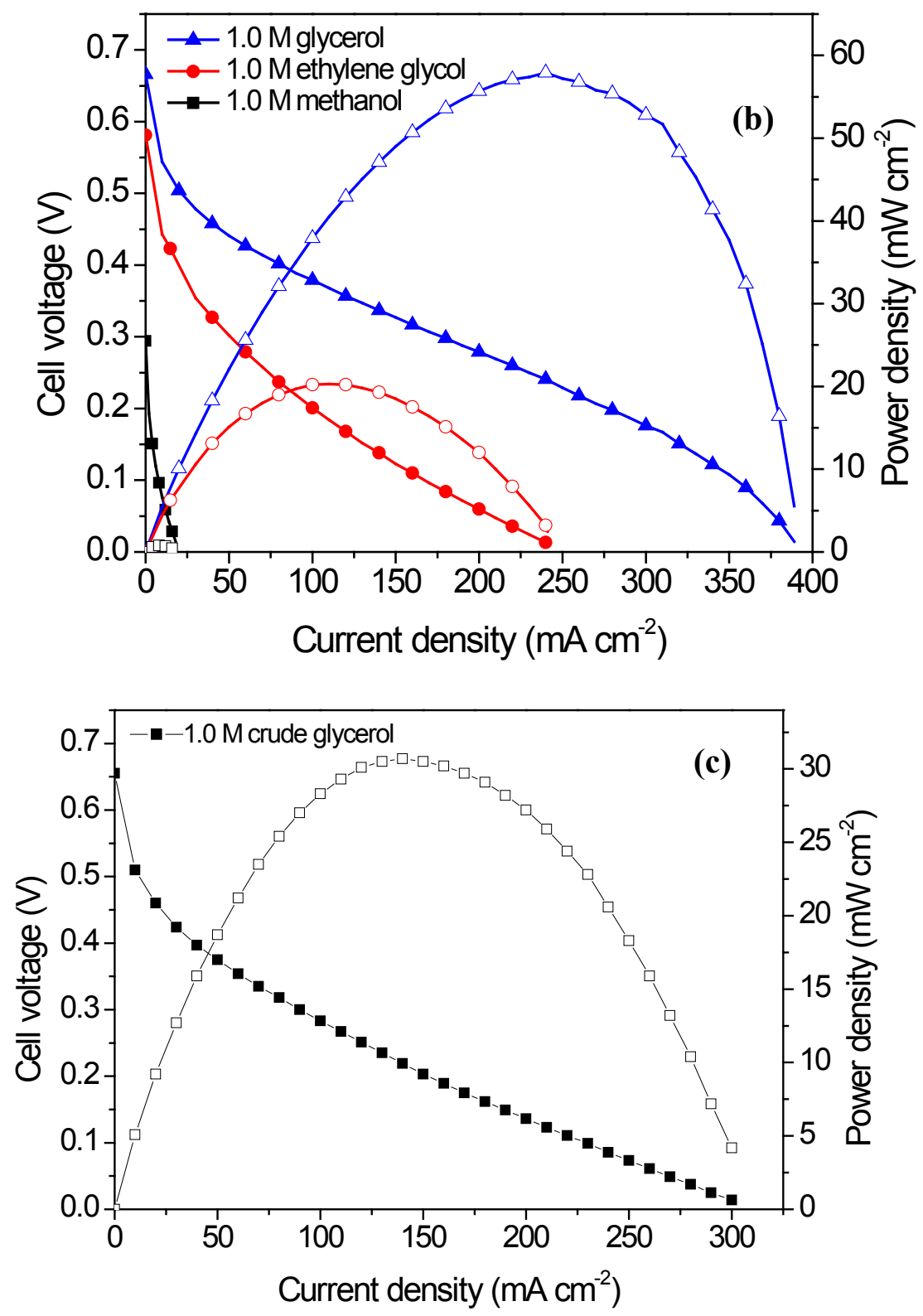

Fig. 6.6 Polarization curves of an AEM-DGFC at operation temperature of 50, 60, 70, and $80^{\circ} \mathrm{C}$, and a proton-exchange membrane direct glycerol fuel cell (PEM-DGFC) at $90^{\circ} \mathrm{C}$ (a), AEMFCs fed with methanol, EG and glycerol at $80^{\circ} \mathrm{C}(\mathrm{b})$, and AEM-DGFC fed with crude glycerol at $80^{\circ} \mathrm{C}$ (c). Test conditions for AEM-DGFC: Anode: $\mathrm{Au} / \mathrm{C}(1.0$ $\mathrm{mg}_{\mathrm{Au}} \mathrm{cm}^{-2}$ ), 2.0 M KOH + 1.0 M alcohol, $4.0 \mathrm{~mL} \mathrm{~min}^{-1}$, cathode: $\mathrm{Fe}-\mathrm{Cu}-\mathrm{N}_{4} / \mathrm{C}$ (Acta 4020, $1.0 \mathrm{mg} \mathrm{cm}$ ) $, \mathrm{O}_{2}, 0.4 \mathrm{Lmin}^{-1}, 30 \mathrm{psi}$, AEM: A201 (28 $\mu \mathrm{m}$, Tokuyama). Test conditions for PEM-DGFC: Anode: PtRu/C (4.0 $\left.\mathrm{mg}_{\mathrm{PtRu}} \mathrm{cm}^{-2}\right), 1.0 \mathrm{M}$ glycerol, $4.0 \mathrm{~mL} \mathrm{~min}^{-1}$, cathode: $\mathrm{Pt} / \mathrm{C}\left(4.0 \mathrm{mg}_{\mathrm{Pt}} \mathrm{cm}^{-2}\right), \mathrm{O}_{2}, 0.4 \mathrm{Lmin}^{-1}, 30$ psi, PEM: Nafion 115 (150 $\mu \mathrm{m}$, Dupont). 
The $\mathrm{Au} / \mathrm{C}$ anode AEM-DGFC with crude glycerol also displayed high durability and stability. Fed with $2.0 \mathrm{M} \mathrm{KOH}+1.0 \mathrm{M}$ crude glycerol, the durability of $\mathrm{Au} / \mathrm{C}$ anode AEM-DGFC was tested through 100 continuous runs of polarization scans at $80^{\circ} \mathrm{C}$. The cathode loading was increased to $2.0 \mathrm{mg} \mathrm{cm}^{-2}$ to minimize the effect of cathode catalyst activity loss within the long-term test at elevated temperature. The initial polarization curve before the durability test in Fig. 6.7 (a) shows a peak power density of $40.1 \mathrm{~mW}$ $\mathrm{cm}^{-2}$, which is $\sim 10 \mathrm{~mW} \mathrm{~cm}{ }^{-2}$ higher than the performance in Fig. 6.6 (c) due to the increase of cathode catalyst loading. The relative peak power densities during the durability test are plotted in Fig. 6.7 (b), which gradually dropped to 53\% of its original value $\left(21.2 \mathrm{~mW} \mathrm{~cm}^{-2}\right)$ after 100 continuous runs. The decrease of peak power density is probably due to the intermediates/poisons generated during the long term reaction which blocked Au surface active sites. After the durability test, the anode was cleaned by flushing with de-ionized water, and the performance was tested again under the same conditions. As shown in Fig. 6.7 (a), the polarization curve demonstrates no drop in electricity generation performance even after 100 continuous runs of durability test, indicating an extremely high stability of the $\mathrm{Au} / \mathrm{C}$ anode catalyst. It is noted that after the durability test, the limiting current increased from $310 \mathrm{~mA} \mathrm{~cm}^{-2}$ to $330 \mathrm{~mA} \mathrm{~cm}^{-2}$, which implies better reactant diffusion was achieved. 

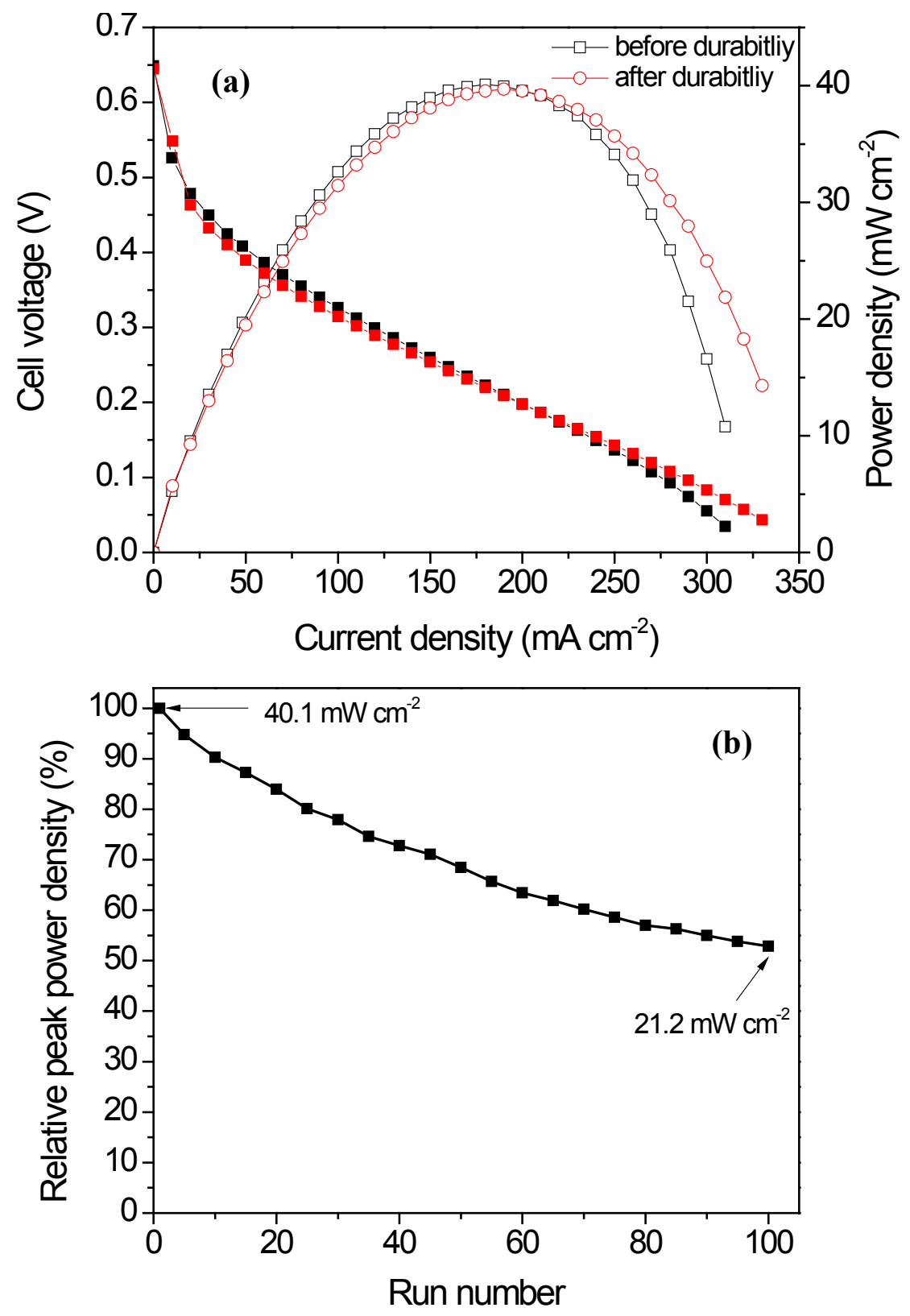

Fig. 6.7 Polarization curves before and after the durability test (a), and the relative peak power density losses within the durability test (b), fed with $2.0 \mathrm{M} \mathrm{KOH}+1.0 \mathrm{M}$ crude glycerol. Test conditions: Anode: $\mathrm{Au} / \mathrm{C}\left(1.0 \mathrm{mg}_{\mathrm{Au}} \mathrm{cm}^{-2}\right), 4.0 \mathrm{mLmin}^{-1}$, cathode: $\mathrm{Fe}-\mathrm{Cu}-$ $\mathrm{N}_{4} / \mathrm{C}$ (Acta 4020, $\left.2.0 \mathrm{mg} \mathrm{cm}^{-2}\right), \mathrm{O}_{2}, 0.4 \mathrm{Lmin}^{-1}, 30 \mathrm{psi}$, AEM: A201 (28 $\mu \mathrm{m}$, Tokuyama), $80^{\circ} \mathrm{C}$. 


\subsubsection{Products analysis and Faradic efficiency investigation}

Table 6. 1 presents the products selectivities analyzed by HPLC under different fuel cell operation voltages. Although the previous studies of glycerol electro-oxidation in traditional three-electrode system by other groups indicate that $\mathrm{Au}$ only produces lightly oxidized products, such as glycerate and glycolate ${ }^{72,74}$, our investigation found that the $\mathrm{Au} / \mathrm{C}$ anode catalyst in AEM-DGFC more favors the generation of deeper-oxidized products, tartronate $(37-49 \%)$ and oxalate $(22-25 \%)$, in the whole fuel cell operation voltage range. At lower cell voltages, the fully oxidized $\mathrm{C}_{3}$ product - mesoxalate was also detected with the selectivity of $19 \%$ and $12 \%$, at 0.3 and $0.1 \mathrm{~V}$, respectively. This is in sharp contrast to heterogeneous catalytic partial oxidation of glycerol over $\mathrm{Au} / \mathrm{C}$ catalysts, through which the main product is glycerate. i.e. Hutchings' group reported a $100 \%$ glycerate selectivity under an optimized condition. ${ }^{17}$ The high selectivity of deeper-oxidized products on $\mathrm{Au} / \mathrm{C}$ in the $\mathrm{AEM}$-DGFC may be attributed to the high catalyst loading and the unique carbon cloth-based liquid diffusion layer, which will elongate the fuel residence time inside the catalyst layer and allow glycerol to undergo deeper oxidations.

\section{Table 6.1}

Product selectivity and Faradic efficiency $\left(\eta_{\mathrm{e}}\right)$ of an AEM-DGFC with $\mathrm{Au} / \mathrm{C}$ anode catalyst under different fuel cell working voltages

\begin{tabular}{ccccccc}
\hline Cell & \multicolumn{5}{c}{ Selectivity (\%) } \\
\cline { 2 - 5 } voltage & Glycerate & Tartronate & Mesoxalate & Glycolate & Oxalate & $\eta_{\mathrm{e}}(\%)$ \\
$(\mathrm{V})$ & & & & & & \\
0.5 & 26 & 49 & 0 & 0 & 25 & 53.3 \\
0.3 & 17 & 39 & 19 & 0 & 25 & 58.6 \\
0.1 & 26 & 37 & 12 & 3 & 22 & 54.1 \\
\hline
\end{tabular}


Based on the product distributions, the Faradic efficiency $\left(\eta_{\mathrm{e}}\right)$ was calculated by equation $(2-12)$ :

$$
\eta_{e}=\sum S_{i} \bullet \eta_{e_{i}}
$$

The higher Faradic efficiency means more electrons are exploited from the fuel, and thus represents a greater utilized fuel energy density. Since full oxidization of glycerol to $\mathrm{CO}_{2}$ yields 14 electrons, the Faradic efficiencies of partial oxidizing glycerol to glycerate (4e-), tartronate $\left(8 \mathrm{e}^{-}\right)$, mesoxalate $\left(10 \mathrm{e}^{-}\right)$, glycolate $\left(6 \mathrm{e}^{-}\right)$, and oxalate $\left(10 \mathrm{e}^{-}\right)$are $28.6 \%, 57.1 \%$, $71.4 \%, 42.9 \%$, and $71.4 \%$, respectively. The calculation is based on that all the $\mathrm{C}_{1}$ product is formic acid. As shown in Table 6.1, the Faradic efficiencies at fuel cell operation voltages of $0.5,0.3$, and $0.1 \mathrm{~V}$ are calculated to be $53.3 \%, 58.6 \%$, and $54.1 \%$, respectively. By comparison, the main oxidation product for direct ethanol fuel cells (DEFCs, ethanol is another important biorenewable alcohol) is acetic acid or acetaldehyde even on the $\mathrm{Pt} / \mathrm{C}$ or $\mathrm{PtSn} / \mathrm{C}$ anode catalyst, due to the difficulty of $\mathrm{C}-\mathrm{C}$ bond cleavage. ${ }^{169,184}$ Therefore, the Faradic efficiency of a DEFC drops down to only $33.3 \%$ (acetic acid), and 16.7\% (acetaldehyde). The AEM-DGFC with $\mathrm{Au} / \mathrm{C}$ anode catalyst has a great advantage in exploiting more electrons from glycerol during its electro-oxidation, and thus improves the fuel efficiency. In order to further study the reaction pathway of glycerol electro-oxidation, a detailed work in Au based electro-catalytic reactors was carried out and described in Chapter 8.

\subsection{Conclusion}

In this chapter, carbon supported $\mathrm{Au}-\mathrm{NPs}(\mathrm{Au} / \mathrm{C})$ catalyst with a small average size of 3.5 $\mathrm{nm}$ was successfully prepared by a modified organic solution phase reduction method. The reactivity of glycerol oxidation on $\mathrm{Au} / \mathrm{C}$ is much higher than that of methanol and EG oxidation in alkaline electrolyte. A subtle balance of glycerol and $\mathrm{OH}^{-}$concentration is required to obtain a high electro-oxidation reactivity. The $\mathrm{Au} / \mathrm{C}$ catalyst has demonstrated a high performance in AEM-DGFC: at $80^{\circ} \mathrm{C}$, the $\mathrm{OCV}$ and peak power density can reach $0.67 \mathrm{~V}$ and $57.9 \mathrm{mWcm}^{-2}$, respectively. Even directly fed with crude 
glycerol, the OCV and peak power density of the AEM-DGFC can still achieve $0.66 \mathrm{~V}$ and $30.7 \mathrm{~mW} \mathrm{~cm}^{-2}$, respectively. The $\mathrm{Au} / \mathrm{C}$ anode also demonstrated high durability: after 100 runs of polarization scans at $80^{\circ} \mathrm{C}$, the $\mathrm{Au} / \mathrm{C}$ anode $\mathrm{AEM}-\mathrm{DGFC}$ shows no obvious performance loss when fed with $2.0 \mathrm{M} \mathrm{KOH}+1.0 \mathrm{M}$ crude glycerol. The product analysis shows electro-oxidation of glycerol on the $\mathrm{Au} / \mathrm{C}$ anode catalyst in AEM-DGFCs favors the formation of deeper-oxidized products: tartronate, mesoxalate, and oxalate, which leads to higher fuel cell's Faradic efficiency. 


\section{Chapter 7 Electro-catalytic oxidation of glycerol on $\mathrm{Pt} / \mathrm{C}$ in anion-exchange membrane fuel cell: Cogeneration of electricity and valuable chemicals*}

\subsection{Introduction}

\subsubsection{Biomass derived glycerol}

The depletion of traditional fossil resources has spurred both the academic and industrial researchers to find non-fossil transportation fuels. Driven by political rather than the economic decisions, the production of biomass derived alternative energy carriers, bioethanol and biodiesel, has increased dramatically in recent years. While bioethanol is mainly obtained from the microorganism fermentation process of biomass, the production of biodiesel is based on a chemical process of transesterification of vegetable oils, or of animal or waste fats. As shown in Fig. 7.1, catalyzed by an acid or base catalyst, the reaction simultaneously cleaves the fatty acids from the glycerol backbone and transforms them into methyl esters, which leaves the glycerol as an inevitable byproduct (10 wt\%). As a result, the market for glycerol has quickly become saturated, leading to a low price of glycerol (0.3 US\$ kg-1 for crude glycerol; $0.6 \mathrm{US} \$ \mathrm{~kg}^{-1}$ for purified glycerol). ${ }^{14}$

\footnotetext{
*The material contained in this chapter was previously published in Applied Catalysis B: Environmental. Reprinted with permission from Applied Catalysis B: Environmental, 2012, 119-120, Zhiyong Zhang, Le Xin, and Wenzhen Li, "Electrocatalytic oxidation of glycerol on $\mathrm{Pt} / \mathrm{C}$ in anion-exchange membrane fuel cell: Cogeneration of electricity and valuable chemicals", 40-48. Copyright 2011 Elsevier.
} 

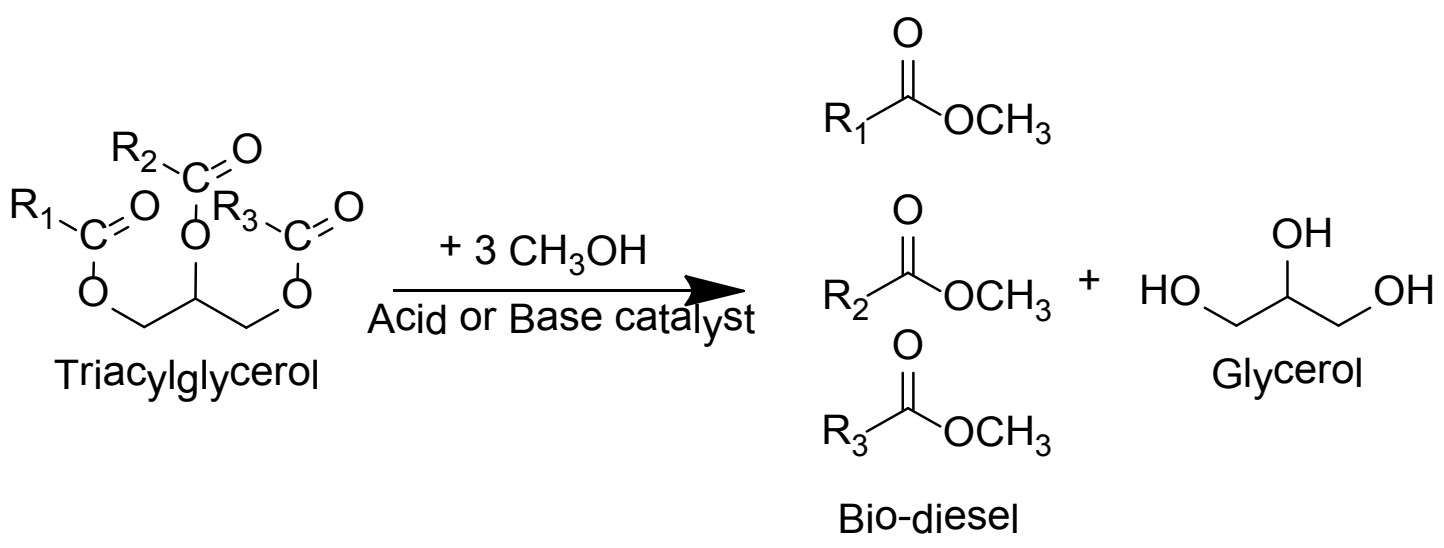

Fig. 7.1 Transesterification of vegetable oils or fats to biodiesel and byproduct glycerol.

\subsubsection{Selective heterogeneous catalytic oxidation of glycerol}

With a highly active triol structure and a low marketing price, glycerol has a great potential to serve as a main building block for the future production of higher-valued oxygenated chemicals, including glyceric acid, tartronic acid, mesoxalic acid, and glycolic acid, et al. ${ }^{13,15}$ However, currently these value-added oxygenates are mostly produced through either costly and non-environmental-friendly stoichiometric oxidation processes, ${ }^{249}$ or slow fermentation processes with low product yields. ${ }^{250}$

To replace these out-of-date processes, extensive researches have been carried out on selective oxidation of glycerol through "green" and fast heterogeneous catalysis using molecular oxygen with mono-metallic catalysts, such as $\mathrm{Pt},{ }^{19,242,249,251-253}$ $\mathrm{Pd},{ }^{19,21,242,249,251,254}$ and $\mathrm{Au},{ }^{17,18,21,76,242,244,249,254-260}$ and multi-metallic catalysts, such as $\mathrm{PtPd},{ }^{261} \mathrm{PtAu},{ }^{262-264} \mathrm{AuPd},{ }^{254,263,265-268} \mathrm{PtBi}^{20,269} \mathrm{PtCu}^{270}$ and $\mathrm{PtPdBi} .{ }^{271}$ It has been found that the activity and product distribution of glycerol oxidation depend on both the catalyst, such as particle size, loading, support, etc, and the reaction conditions, such as $\mathrm{pH}$, glycerol:catalyst ratio, $\mathrm{O}_{2}$ pressure, etc. Gallezot and his co-workers studied glycerol oxidation on $\mathrm{Pt}$ and $\mathrm{Pd}$ at different $\mathrm{pHs}$ and observed that the initial glycerol oxidation rate increased significantly with increased $\mathrm{pH}$ of reaction media on both catalysts. ${ }^{19,251,272}$ They also found that the oxidation of primary $-\mathrm{OH}$ is more favorable than that of 
secondary - $\mathrm{OH}$ in alkaline solutions. Groups of Hutchings and Prati separately studied glycerol oxidation on Au and achieved very high selectivity to glycerate (the salt form of glyceric acid) under their optimized conditions. ${ }^{17,18}$ Hutchings et al also investigated the effects of $\mathrm{O}_{2}$ pressure and catalyst loading on glycerol oxidation on $\mathrm{Pt} / \mathrm{C}$ in basic environments, and found that lower $\mathrm{O}_{2}$ pressure and higher catalyst loading favor the oxidative cleavage of $\mathrm{C}-\mathrm{C}$ bonds in glycerol and reaction intermediates to yield $\mathrm{C}_{1}$ products. ${ }^{249}$ Despite great progress in the oxidation of glycerol, previous research was heavily focused on selective oxidation of one hydroxyl group to glyceric acid (glycerate in alkaline solution) or dihydroacetone, and $\mathrm{C}-\mathrm{C}$ bond breaking to glycolic acid (glycolate in alkaline solution). Glycerate is the only $\mathrm{C}_{3}$ product that has shown high selectivity through heterogeneous catalysis in alkaline media. It is hard to obtain further oxidized $\mathrm{C}_{3}$ products (tartronate and mesoxalate). Tartronate is usually a low selectivity byproduct when oxidizing glycerol to glycerate. ${ }^{249}$ Mesoxalate has rarely been reported as a product from catalytic oxidation of glycerol on the metallic catalysts in batch reactors in high $\mathrm{pH}$ media.

\subsubsection{Relationship between heterogeneous catalysis and fuel cell reactions}

Recently, Davis and co-workers' elegant work revealed the roles of $\mathrm{OH}^{-}$and $\mathrm{O}_{2}$ on metallic catalyst (Au or Pt) surfaces based on HPLC-MS analysis, ${ }^{18} \mathrm{O}$ isotope tracing, and DFT calculation. ${ }^{76}$ They found that $\mathrm{OH}^{-}$in the reaction media can greatly facilitate glycerol oxidation, and the role of $\mathrm{O}_{2}$ is simply to facilitate the $\mathrm{OH}^{-}$regeneration loop via a 2-electron-transfer process on $\mathrm{Au}$ (or a 4-electron-transfer process on $\mathrm{Pt}$ ). The function of $\mathrm{O}_{2}$ in heterogeneous catalytic oxidation of glycerol is similar to the $\mathrm{O}_{2}$ reduction reaction (ORR) at the fuel cell cathode. However, due to restrictions in the design and nature of traditional batch reactors, the chemical energy stored in glycerol $\left(6.3 \mathrm{kWh} \mathrm{L}^{-1}\right)$ has been wasted in the catalytic oxidation process (it is just converted to thermal energy in the oxidation). From energy conservation, economic, and environmental aspects, it is 
desirable to develop new catalytic processes to cogenerate both energy and value-added chemicals from these biorenewable compounds.

In this chapter, cogeneration of electricity and higher-valued chemicals from glycerol electro-catalytic oxidation was successfully achieved in a single AEMFC by separating the $\mathrm{O}_{2}$ reduction reaction (cathode) from the glycerol catalytic oxidation (anode). Carbon supported Pt nanoparticles $(1-4 \mathrm{~nm})$ served as the catalyst for glycerol electrooxidation, ${ }^{92,93,107,208,211,212}$ which not only demonstrated decent electricity generation performance $\left(124.5 \mathrm{~mW} \mathrm{~cm}{ }^{-2}\right.$ at $\left.80^{\circ} \mathrm{C}\right)$, but also showed unique catalytic selectivity towards higher-valued chemicals, such as glycerate, glycolate, and tartronate. It is interesting to find that the fuel cell operation voltage (anode overpotential) could regulate the product distributions. In addition, the fully oxidized $\mathrm{C}_{3}$ acid, mesoxalate, was directly produced in this alkaline cogeneration system.

\subsection{Experimental}

\subsubsection{Preparation of Pt/C catalysts}

$\mathrm{Pt} / \mathrm{C}$ catalyst was synthesized through an organic solution phase reduction method. ${ }^{92,208,209,212}$ In detail, $196.7 \mathrm{mg}$ of $\mathrm{Pt}(\mathrm{acac})_{2}(0.5 \mathrm{mmol}), 200 \mu 1$ of oleylamine, and $200 \mu 1$ of oleic acid were dissolved in a mixture of $146.3 \mathrm{mg}$ of carbon black and $40 \mathrm{ml}$ of benzyl ether (Acros Organics, 99\%) at $60^{\circ} \mathrm{C}$ in an inert $\mathrm{N}_{2}$ atmosphere. As the temperature increased to $120^{\circ} \mathrm{C}, 1.0 \mathrm{ml}$ of $\mathrm{LiBEt}_{3} \mathrm{H}$ ( $1 \mathrm{M}$ in THF, Acros Organics) was quickly injected into the system. The temperature was held constant for 30 minutes, slowly increased to $180^{\circ} \mathrm{C}$, and held there for another 30 minutes. The final $\mathrm{Pt} / \mathrm{C}$ catalyst (40 wt\%) was obtained by filtration, washed with copious ethanol, and dried in a vacuum oven at $50^{\circ} \mathrm{C}$ overnight. Following a similar procedure, a $4.6 \mathrm{wt} \% \mathrm{Pt} / \mathrm{C}$ catalyst was also prepared. 


\subsubsection{Physical characterizations}

X-ray diffraction (XRD), transmission electron microscopy (TEM) were employed to analyze the structure and morphology of $\mathrm{Pt} / \mathrm{C}$.

\subsubsection{MEA fabrication and electro-oxidation of glycerol in AEM-DGFC}

The MEA was fabricated and tested by the procedure detailed in Section 2.4.2.1 and

2.4.2.2. The cathode catalyst loading was maintained at $1.0 \mathrm{mg}_{\text {catalyst }} \mathrm{cm}^{-2}$, while the anode catalyst loading was controlled at 1.0 or $0.1 \mathrm{mg}_{\mathrm{Pt}} \mathrm{cm}^{-2}$. The electricity generation performances were evaluated with a $2.0 \mathrm{M} \mathrm{KOH}+1.0 \mathrm{M}$ glycerol solution and highpurity $\mathrm{O}_{2}(99.999 \%)$ at 50 and $80^{\circ} \mathrm{C}$. The glycerol electro-oxidation and product analysis were performed by the procedure in Section 2.4.2.3. During the glycerol oxidation test, the anode overpotential was monitored with a $\mathrm{Hg} / \mathrm{HgO} / 1.0 \mathrm{M} \mathrm{KOH}$ electrode, and reported $v s$. SHE for convenience. All the products investigated are in their deprotonated (salt) forms in alkaline media.

\subsubsection{Electro-oxidation of glycerol in half cell with online sample collection system}

The online sample collection was performed by the procedure in Section 2.3.1.4, in both $0.1 \mathrm{M} \mathrm{KOH}+0.1 \mathrm{M}$ glycerol and 1.0 M KOH $+1.0 \mathrm{M}$ glycerol solutions. $\mathrm{A} \mathrm{Hg} / \mathrm{HgO} / 1.0$ $\mathrm{M} \mathrm{KOH}$ was employed as the reference electrode. However, the potential is reported $v s$. SHE to keep consistent with the AEMFC investigations. Prior to the tests, $2.0 \mathrm{mg}$ of Pt/C catalyst were dispersed in $1.0 \mathrm{ml}$ isopropanol by sonication to form a uniform ink. The working electrode was prepared by dropping $40 \mu \mathrm{l}$ of the ink onto the glassy carbon electrode. $20 \mu \mathrm{l}$ of $0.05 \mathrm{wt} \%$ AS-4 anion conductive ionomer solution was then added on the top to affix the catalyst. 


\subsubsection{Products analysis}

The product distribution was analyzed by the procedure described in Section 2.4.2.3. The selectivity $(\mathrm{S})$ is calculated by equation (2-9):

$$
\text { Selectivity }=\frac{\text { Moles of specific product forms }}{\text { Total moles of } C_{2} \text { and } C_{3} \text { products detected }} \times 100 \%
$$

The carbon balance is calculated by equation (2-11):

$$
\text { Carbon balance }=\frac{M_{G_{i}}-M_{C_{3}}-M_{C_{2}}-M_{G_{f}}}{M_{G_{i}}} \times 100 \%
$$

where $\mathrm{M}_{\mathrm{Gi}}$ and $\mathrm{M}_{\mathrm{Gf}}$ are the initial and final moles of glycerol in the electrolyte, $\mathrm{M}_{\mathrm{C} 3}$ and $\mathrm{M}_{\mathrm{C} 2}$ are the moles of $\mathrm{C}_{3}$ products (glycerate, tartronate, and mesoxalate) and $\mathrm{C}_{2}$ products (glycolate and oxalate), respectively. A smaller carbon balance indicates less $\mathrm{C}_{2}$ chemicals were further oxidized to $\mathrm{C}_{1}$ products

\subsection{Results and discussion}

\subsubsection{Physical characterization}

The XRD pattern of Pt/C catalyst is shown in Fig. 7.2 (a), which displayed a typical facecentered cubic (FCC) pattern. The average metal crystal size of $\mathrm{Pt} / \mathrm{C}$ catalyst calculated based on the Pt (220) diffraction peak is $1.9 \mathrm{~nm}$, using the Debye-Scherrer formula (equation (2-1):

$$
L=\frac{0.9 \lambda_{K \alpha}}{B_{2 \theta} \cos \theta_{\max }}
$$

A typical TEM image of Pt/C and its corresponding histogram are shown in Fig. 7.2 (b). It is observed that most of the nanoparticles are round in shape and are uniformly dispersed on carbon support with only few agglomerations. The average particle size evaluated from the TEM image is $2.4 \mathrm{~nm}$ for $\mathrm{Pt} / \mathrm{C}$ catalyst, which is in good agreement 
with the XRD result. The histogram of particle sizes (Fig. 7.2 (c)) counted from 100 randomly chosen particles in an arbitrary area shows a narrow size distribution of $1-4$ $\mathrm{nm}$.

\subsubsection{Electricity generation performance of anion exchange membrane direct glycerol fuel cells (AEM-DGFCs)}

$\mathrm{Pt} / \mathrm{C}$ has demonstrated high activity towards electro-catalytic oxidation of glycerol in AEM-DGFC. As shown in Fig. 7.3, fed with an anode fuel of $2.0 \mathrm{M} \mathrm{KOH}+1.0 \mathrm{M}$ glycerol, the AEM-DGFC with an anode catalyst loading of $1.0 \mathrm{mg}_{\mathrm{Pt}} \mathrm{cm}^{-2}$ yields an open circuit voltage (OCV) of $0.796 \mathrm{~V}$ and a peak power density of $58.6 \mathrm{~mW} \mathrm{~cm}^{-2}$ at $50^{\circ} \mathrm{C}$. At a higher temperature of $80^{\circ} \mathrm{C}$, the $\mathrm{OCV}$ and peak power density can reach to $0.850 \mathrm{~V}$, $124.5 \mathrm{~mW} \mathrm{~cm}^{-2}$, respectively, due to the benefits of better reaction kinetics and fuel diffusion. When the anode catalyst loading is reduced to $0.1 \mathrm{mg}_{\mathrm{Pt}} \mathrm{cm}^{-2}$ with $\mathrm{Pt} / \mathrm{C}$ (4.6 $\mathrm{wt} \%$ ) the peak power density of AEM-DGFC remains $69.1 \mathrm{~mW} \mathrm{~cm}{ }^{-2}$ at $80^{\circ} \mathrm{C}$. The demonstrated power density represents $2-3$ orders of magnitude higher than that of the current biofuel cells, ${ }^{246,247}$ and is also higher than the published results with Pd-based anode catalysts, ${ }^{184,233}$ which indicate Pt/C catalyst with small particles size $(1-4 \mathrm{~nm})$ possesses a high electro-catalytic activity toward glycerol oxidation in real fuel cell operations. In addition, the performance observed in AEMFC is over an order of magnitude higher than that of the proton exchange membrane - direct glycerol fuel cell (PEM-DGFC) with the PtRu/C anode and Pt/C cathode catalysts with heavy loadings (8 $\mathrm{mg}_{\mathrm{PGM}} \mathrm{cm}^{-2}$ MEA $)$. The comparison of electrical performances of AEM- and PEM- DGFCs is consistent with the results found in heterogeneous catalysis: the glycerol oxidation will be facilitated in high $\mathrm{OH}^{-}$concentrations. ${ }^{76,251}$ 

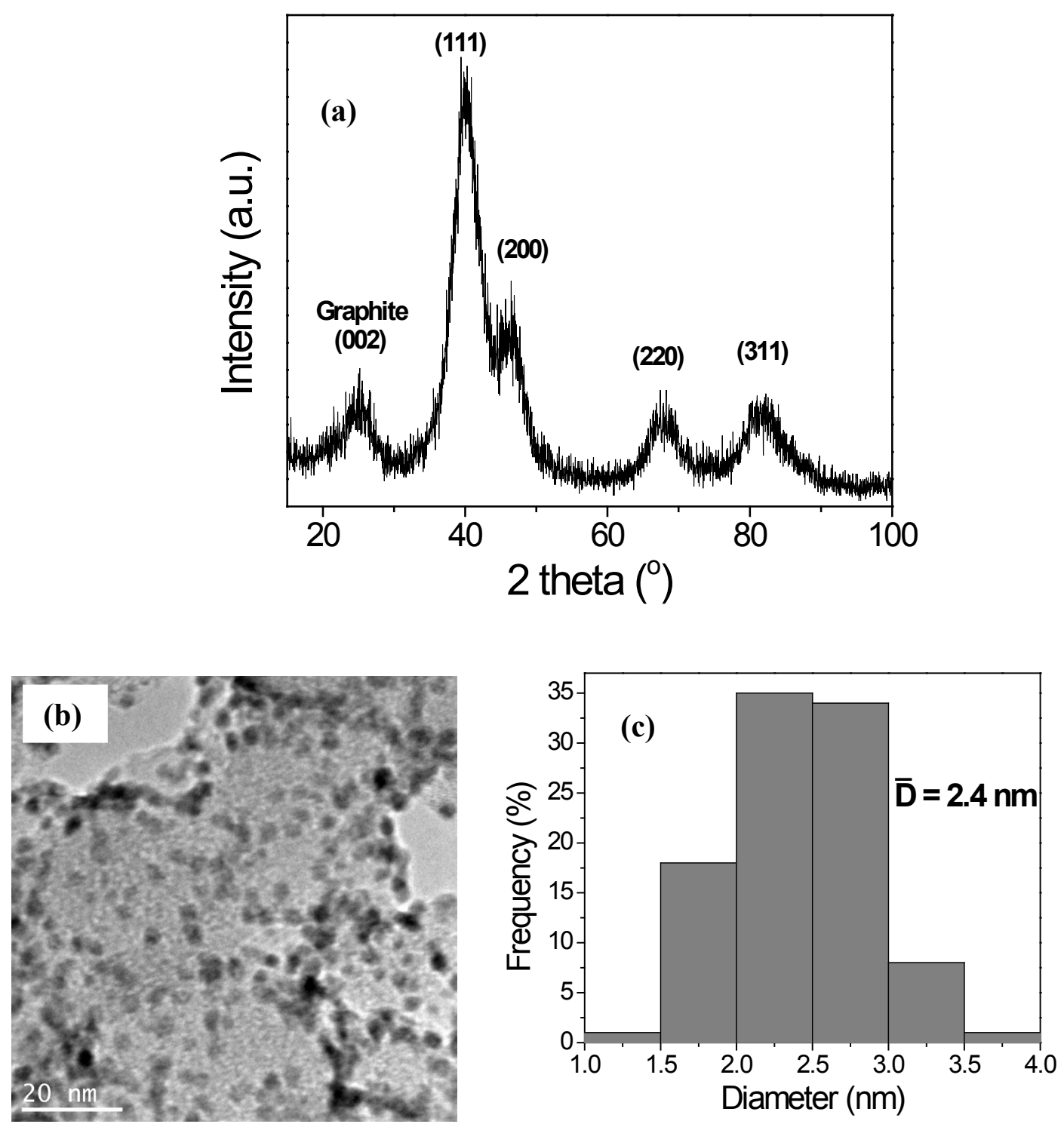

Fig. 7.2 Morphology characterizations: (a) XRD pattern, (b) TEM image, and (c) particle size distribution of $\mathrm{Pt} / \mathrm{C}$ catalyst. 


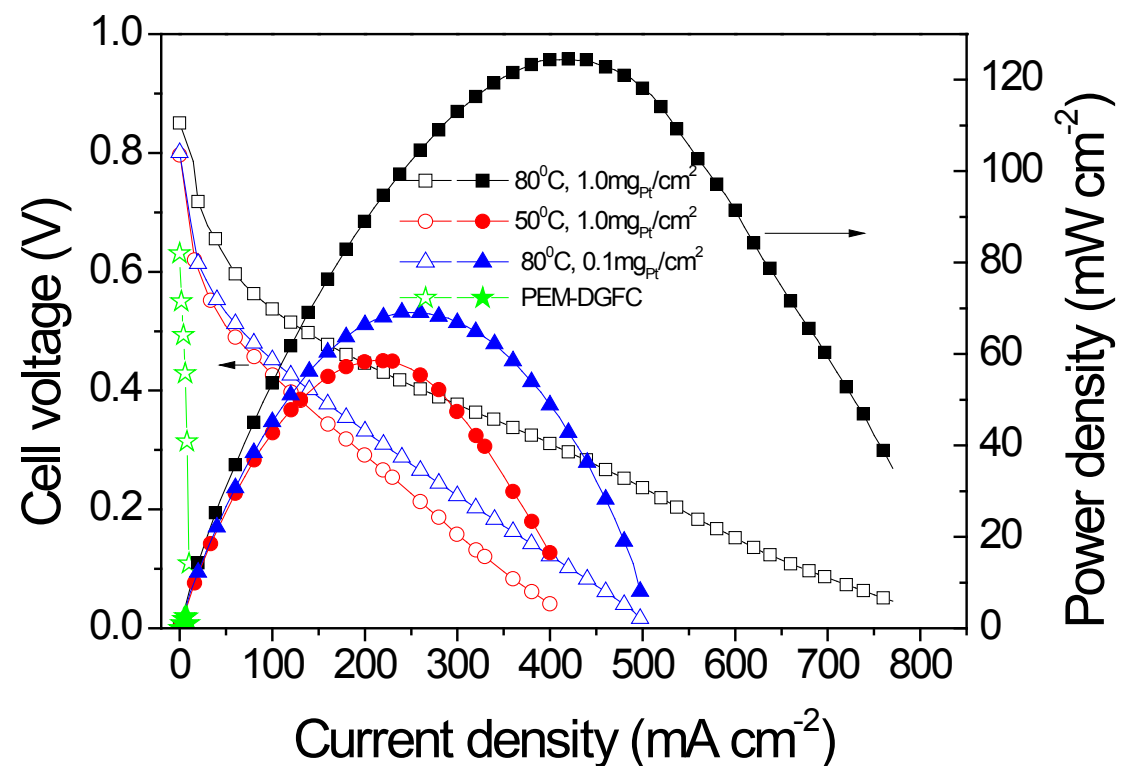

Fig. 7.3 Polarization curves of AEM-DGFC at operation temperature of $50^{\circ} \mathrm{C}$ and $80^{\circ} \mathrm{C}$. Anode: $\mathrm{Pt} / \mathrm{C}(40 \mathrm{wt} \%), 1.0 \mathrm{mg}_{\mathrm{Pt}} \mathrm{cm}^{-2}$, or Pt/C (5 wt\%), $0.1 \mathrm{mg}_{\mathrm{Pt}} \mathrm{cm}^{-2}$; cathode: $\mathrm{Fe}-\mathrm{Cu}-$ $\mathrm{N}_{4} / \mathrm{C}$ (Acta 4020) $1.0 \mathrm{mg} \mathrm{cm}^{-2}$, Membrane: Tokuyama A201, $28 \mu \mathrm{m} .2 .0 \mathrm{M} \mathrm{KOH}+1.0$ $\mathrm{M}$ glycerol. $\mathrm{O}_{2}: 0.4 \mathrm{~L} \mathrm{~min}{ }^{-1}, 30$ psi. PEM-DGFC: Anode: PtRu/C $\left(4.0 \mathrm{mg}_{\mathrm{PtRu}} \mathrm{cm}^{-2}\right)$, cathode: PtRu/C (4.0 $\left.\mathrm{mg}_{\mathrm{Pt}} \mathrm{cm}^{-2}\right)$, membrane: Nafion 115 .

\subsubsection{Electro-catalytic oxidation of glycerol in AEM-DGFCs}

\subsubsection{Cogeneration of electricity and higher-valued chemicals}

To investigate the cogeneration of electricity and valuable products on $\mathrm{Pt} / \mathrm{C}$ in AEMDGFC, $55 \mathrm{ml} 2.0 \mathrm{M} \mathrm{KOH}+1.0 \mathrm{M}$ glycerol was continuously looped from an anode fuel vessel into the anode for 2 hours. The fuel cell operation voltage was controlled at 0.7 , $0.5,0.3$, and $0.1 \mathrm{~V}$, to represent the operation in the close $\mathrm{OCV}$, high working voltage, high power density and high current density conditions. As summarized in Fig. 7.4 (a), the average power density and current density (within 2 hours) are $6.6 \mathrm{~mA} \mathrm{~cm}^{-2}$ and 4.5 $\mathrm{mW} \mathrm{cm}{ }^{-2}, 50.0 \mathrm{~mA} \mathrm{~cm}{ }^{-2}$ and $25.0 \mathrm{~mW} \mathrm{~cm}^{-2}, 158.9 \mathrm{~mA} \mathrm{~cm}^{-2}$ and $47.6 \mathrm{~mW} \mathrm{~cm}^{-2}$, and $136.3 \mathrm{~mA} \mathrm{~cm}^{-2}$ and $32.5 \mathrm{~mW} \mathrm{~cm}^{-2}$, for fuel cell operation voltage at $0.7,0.5,0.3$, and 0.1 $\mathrm{V}$, respectively. The average power density and current density are slightly lower than the values shown in Fig. 7.3 (regular I-V scan with open fuel-feeding), because the glycerol 
concentration gradually decreased during the long reaction time ( 2 hours), due to cycled fuel-feeding. The high and stable AEMFC performance further suggests that fast kinetics of glycerol oxidation is not necessarily associated with complete oxidation of glycerol to $\mathrm{CO}_{2}$ (as what has been achieved in biofuel cells).

Table 7.1

Electro-oxidation of glycerol over Pt/C in AEM-DGFC with different base / glycerol concentrations at different fuel cell operation voltages.

\begin{tabular}{|c|c|c|c|c|c|c|c|c|c|}
\hline & \multirow{2}{*}{$\begin{array}{c}\text { Cell } \\
\text { voltage } \\
(\mathrm{V})\end{array}$} & \multicolumn{6}{|c|}{ Selectivity $^{\mathrm{a}}(\%)$} & \multirow{2}{*}{$\begin{array}{c}\text { Glycerol } \\
\text { conversion } \\
(\%)\end{array}$} & \multirow{2}{*}{$\begin{array}{l}\text { Power } \\
\text { density } \\
(\mathrm{mW} \\
\left.\mathrm{cm}^{-2}\right)\end{array}$} \\
\hline & & $\mathrm{C}_{3}$ & GLY & TAR & MES & GLC & OXA & & \\
\hline \multirow{4}{*}{$\begin{array}{c}2.0 \mathrm{M} \\
\mathrm{KOH} \\
+ \\
1.0 \mathrm{M} \\
\text { glycerol }\end{array}$} & 0.7 & 84 & 47 & 37 & 0 & 16 & 0 & 4.4 & 4.5 \\
\hline & 0.5 & 81 & 41 & 40 & 0 & 4 & 15 & 10.5 & 25.0 \\
\hline & 0.3 & 79 & 44 & 33 & 2 & 5 & 16 & 21.5 & 47.6 \\
\hline & 0.1 & 70 & 34 & 33 & 3 & 8 & 22 & 37.1 & 32.5 \\
\hline \multirow{3}{*}{$\begin{array}{c}4.0 \mathrm{M} \\
\mathrm{KOH} \\
+ \\
1.0 \mathrm{M} \\
\text { glycerol }\end{array}$} & 0.7 & 83 & 46 & 37 & 0 & 17 & 0 & 3.1 & 4.5 \\
\hline & 0.5 & 87 & 41 & 45 & 1 & 5 & 8 & 10.7 & 26.8 \\
\hline & 0.3 & 85 & 40 & 42 & 3 & 5 & 10 & 23.7 & 58.4 \\
\hline \multirow{3}{*}{$\begin{array}{c}0.5 \mathrm{M} \\
\mathrm{KOH} \\
+ \\
1.0 \mathrm{M} \\
\text { glycerol }\end{array}$} & 0.7 & 78 & 44 & 34 & 0 & 22 & 0 & 0.6 & 1.3 \\
\hline & 0.5 & 71 & 38 & 33 & 0 & 15 & 14 & 3.1 & 8.9 \\
\hline & 0.3 & 70 & 49 & 21 & 0 & 13 & 17 & 9.9 & 20.8 \\
\hline \multirow{3}{*}{$\begin{array}{c}2.0 \mathrm{M} \\
\mathrm{KOH} \\
+ \\
0.1 \mathrm{M} \\
\text { glycerol }\end{array}$} & 0.7 & 91 & 41 & 50 & 0 & 9 & 0 & 4.7 & 0.7 \\
\hline & 0.5 & 76 & 40 & 36 & 0 & 8 & 16 & 14.8 & 7.7 \\
\hline & 0.3 & 62 & 21 & 34 & 7 & 10 & 28 & 63.7 & 17.0 \\
\hline${ }^{\mathrm{a}} \mathrm{GLY}=\mathrm{g}$ & rate; T & $\mathrm{R}=\mathrm{t}$ & trona & MES & meso & ate; & $\mathrm{C}=\mathrm{gly}$ & late: $\mathrm{OXA}=$ & xalate \\
\hline
\end{tabular}



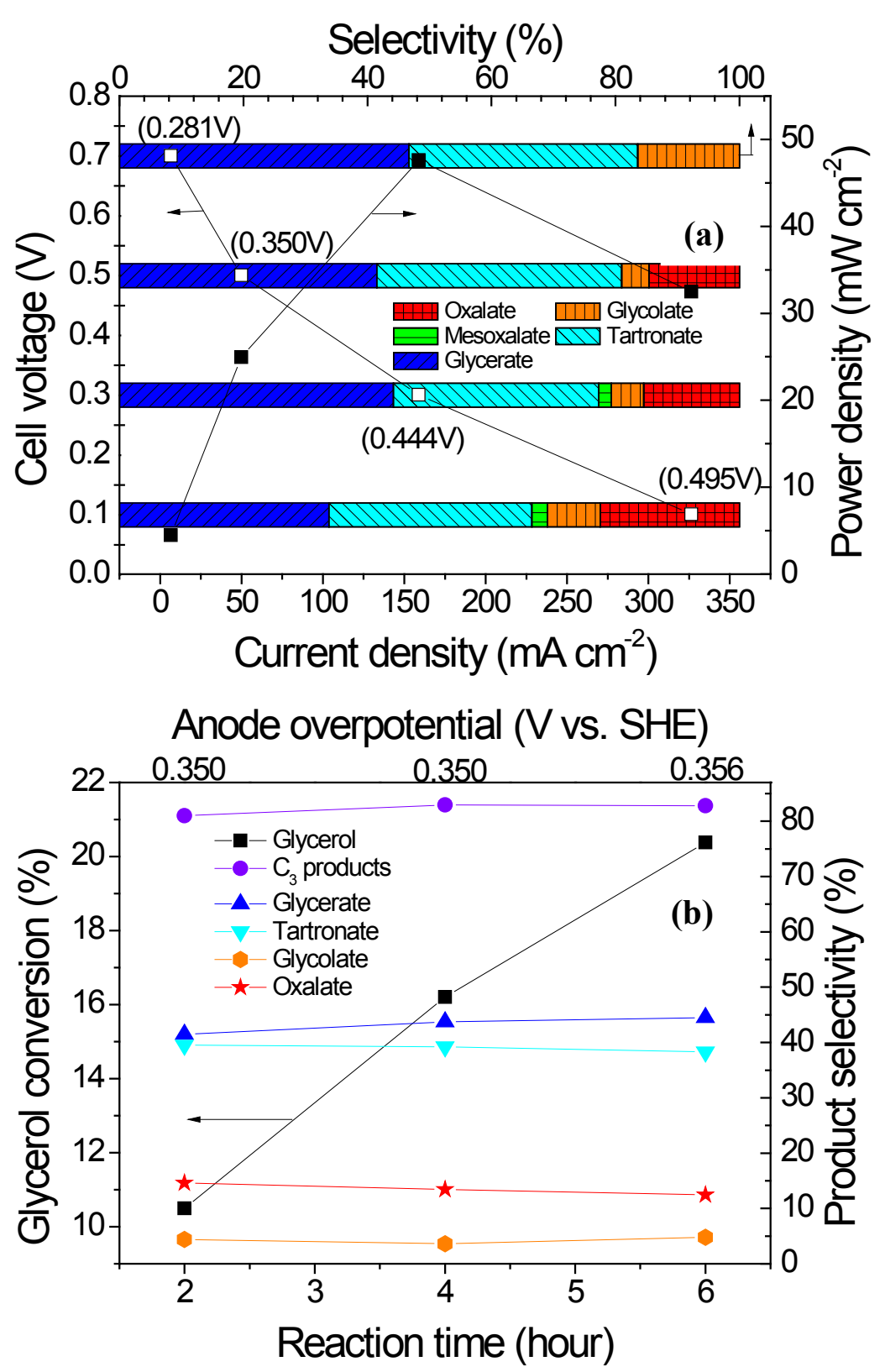

Fig. 7.4 (a) Electricity generation and products distribution from electro-catalytic oxidation of glycerol in AEMFC with $2.0 \mathrm{M} \mathrm{KOH}+1.0 \mathrm{M}$ glycerol at $50^{\circ} \mathrm{C}$, at cell operation voltage of $0.7,0.5,0.3$ and $0.1 \mathrm{~V}$ with an operation duration of 2 hours, anode overpotential (vs. SHE) marked in parenthesis; (b) Products distribution with different operation duration at $50^{\circ} \mathrm{C}$ and the cell operation voltage of $0.5 \mathrm{~V}$.

The products were collected after 2 hours of reaction and analyzed by HPLC. The selectivity to each product was calculated by equation (2-9). The oxidation products distributions under different operation voltages are summarized in Fig. 7.4 (a) and Table 
7.1. Traditional heterogeneous catalysis of glycerol oxidation in basic environment has been inefficient in the generation of deeper oxidized $\mathrm{C}_{3}$ products (tartronate and mesoxalate). Tartronate selectivity is normally $<7 \%$ on Pt/C catalyst in traditional batch reactors with a $\mathrm{OH}^{-}$to glycerol ratio of $2: 1^{76,249}$ Even at an extremely high glycerol: catalyst ratio of 100:1 $\left(\mathrm{mol} \mathrm{mol}^{-1}\right)$, the tartronate selectivity in batch reactor is usually lower than $30 \% .{ }^{249}$ Although a high selectivity of mesoxalic acid of $70 \%$ is reported by oxidizing tartronic acid in acid $(\mathrm{pH}=1.5),{ }^{273}$ to the best of our knowledge, no mesoxalate has ever been reported on metallic catalysts in basic environment batch reactor operations, due to low reactivity of the secondary hydroxyl. However, different from the traditional catalytic oxidation of glycerol in batch reactor, the fuel cell reactor uniquely facilitates deeper oxidized $\mathrm{C}_{3}$ acids. The selectivity of tartronate can reach around $33-40 \%$ in the whole fuel cell operation voltage range. In addition, it is interesting to find that at the fuel cell operation voltage of $<0.3 \mathrm{~V}, 2-3 \%$ of mesoxalate was collected in the AEMFC anode. The high selectivity of tartronate, together with the existence of fully oxidized $\mathrm{C}_{3}$ products, mesoxalate, strongly suggests that AEM-DGFC has unique ability to facilitate deeply oxidizing glycerol without breaking $\mathrm{C}-\mathrm{C}$ bonds, as compared with glycerol oxidation in traditional heterogeneous catalytic batch reactors. In addition, more electrons transferred in producing deeper-oxidized products leads to a higher Faradic efficiency of fuel cell operation.

On the other hand, the results clearly show the fuel cell operation voltage has an ability to control the product distribution: as the fuel cell voltage reduces, a clear trend of the $\mathrm{C}_{3}$ product selectivity drop has been observed from $84 \%$ to $70 \%$. Moreover, the fuel cell voltage also affected the $\mathrm{C}_{2}$ product selectivity. At the cell voltage of $0.7 \mathrm{~V}$, the only $\mathrm{C}_{2}$ product was glycolate $(16 \%)$. With the operation voltage decreasing to $0.5 \mathrm{~V}$, the main $\mathrm{C}_{2}$ product was oxalate $(15 \%)$. As the fuel cell voltage operated at $0.1 \mathrm{~V}$, the selectivity of oxalate further increased to $22 \%$. To investigate the effects of fuel cell operation voltage on the product selectivity, a $\mathrm{Hg} / \mathrm{HgO} / 1.0 \mathrm{M} \mathrm{KOH}$ electrode was used to monitor the anode overpotentials, which are $0.281,0.350,0.444$, and $0.495 \mathrm{~V} v s$. SHE at the fuel cell operation voltages of $0.7,0.5,0.3$ and $0.1 \mathrm{~V}$, respectively. The higher potential (electrical energy) applied on the anode obviously leads to deeper oxidations of glycerol, resulting 126 
in the formation of more oxalate and mesoxalate. Thus, it provides a feasible way to tune the product distributions through controlling the cell operation voltage (anode overpotential).

To further study the voltage effect on catalyst selectivity, $55 \mathrm{ml} 2.0 \mathrm{M} \mathrm{KOH}+1.0 \mathrm{M}$ glycerol solution was cycled into the anode for a longer reaction time (6 hours) at the cell voltage of $0.5 \mathrm{~V}$. It can be seen from Table 7.2 that while glycerol conversion increased linearly during the entire test duration, power density decreased linearly due to the decreasing glycerol concentration. However, as shown in Fig. 7.4 (b), the anode overpotential was stable in the range of $0.350-0.356 \mathrm{~V}$, indicating that the anode overpotential could be controlled by regulating the fuel cell operation voltage. During the test, a $0.5 \mathrm{ml}$ sample was taken from the system every 2 hours for product analysis. The results as a function of time are shown in Fig. 7.4 (b). All product selectivities kept almost constant with time, and no mesoxalate or other products were found in the system at the fuel cell voltage of $0.5 \mathrm{~V}$ during the whole operation. This strongly indicated that the product selectivity can be well controlled by the cell operation voltage (anode overpotential).

Table 7.2

Electro-oxidation of glycerol over Pt/C in AEM-DGFC with 2.0M KOH $+1.0 \mathrm{M}$ glycerol at the fuel cell voltage of $0.5 \mathrm{~V}$ for different time.

\begin{tabular}{|c|c|c|c|c|c|c|c|c|}
\hline \multirow{2}{*}{$\begin{array}{l}\text { Reactio } \\
\mathrm{n} \\
\text { duration } \\
\text { (hour) }\end{array}$} & \multicolumn{6}{|c|}{ Selectivity $^{\mathrm{a}}(\%)$} & \multirow{2}{*}{$\begin{array}{c}\text { Glycerol } \\
\text { conversion } \\
(\%)\end{array}$} & \multirow{2}{*}{$\begin{array}{l}\text { Power density } \\
\left.(\mathrm{mW} \mathrm{cm})^{-2}\right)\end{array}$} \\
\hline & $\mathrm{C}_{3}$ & GLY & TAR & MES & GLC & OXA & & \\
\hline 2 & 81 & 41 & 40 & 0 & 4 & 15 & 10.5 & 25.0 \\
\hline 4 & 83 & 44 & 39 & 0 & 4 & 13 & 16.2 & 21.9 \\
\hline 6 & 83 & 45 & 38 & 0 & 5 & 12 & 20.4 & 19.3 \\
\hline
\end{tabular}


After the 6 hour test, the volume of the electrolyte slightly increased to $\sim 56 \mathrm{ml}$, which is higher than the original volume of $55 \mathrm{ml}$, due to the continuous generation of $\mathrm{H}_{2} \mathrm{O}$ at the anode during the test. The glycerol and oxidation products trapped in the reaction system (mainly in catalyst layer and diffusion layer) were collected by flushing with de-ionized water until the OCV dropped to $0.01 \mathrm{~V}$. The overall carbon balance is calculated by the equation (2-11):

$$
\text { Carbon balance }=\frac{M_{G_{i}}-M_{C_{3}}-M_{C_{2}}-M_{G_{f}}}{M_{G_{i}}} \times 100 \%
$$

where $\mathrm{M}_{\mathrm{C} 3}, \mathrm{M}_{\mathrm{C} 2}$ and $\mathrm{M}_{\mathrm{Gf}}$ also include the amount of trapped chemicals. By this method, the carbon balance for the AEM-DGFC operated at a voltage of $0.5 \mathrm{~V}, 6$ hours is $6.5 \%$. The carbon balances for the AEM-DGFC operation voltage at $0.7,0.3$, and $0.1 \mathrm{~V}$ are $4.3 \%, 14.0 \%$, and $26.1 \%$, respectively. The carbon balance is high at low fuel cell voltage, indicating some $\mathrm{C}_{2}$ products (glycolate and oxalate) may be further oxidized to $\mathrm{C}_{1}$ products (formic acid or carbonic acid) on the highly active $\mathrm{Pt} / \mathrm{C}$ catalyst.

\subsubsection{Effects of base concentration}

To evaluate the $\mathrm{KOH}$ effects, $1.0 \mathrm{M}$ glycerol mixed with $4.0 \mathrm{M}$ or $0.5 \mathrm{M} \mathrm{KOH}$ as fuel was cycled into the anode for 2 hours, and the results are shown in Fig. 7.5. Comparison between Fig. 7.4 (a) and Fig. 7.5 reveals that higher $\mathrm{KOH}$ concentration will lead to higher electricity generation performance. The average power density at $0.3 \mathrm{~V}$ with $4.0 \mathrm{M}$ $\mathrm{KOH}+1.0 \mathrm{M}$ glycerol is $58.4 \mathrm{~mW} \mathrm{~cm}{ }^{-2}$, which is almost three times of that with $0.5 \mathrm{M}$ $\mathrm{KOH}+1.0 \mathrm{M}$ glycerol $\left(20.8 \mathrm{~mW} \mathrm{~cm}{ }^{-2}\right)$. This can be attributed to the following reasons. First, the higher $\mathrm{OH}^{-}$concentration will improve $\mathrm{OH}^{-}$diffusion at the anode, thus, increasing the fuel cell electricity performance. ${ }^{274}$ Second, according to the bi-functional theory, the oxidation of alcohol is governed by the coverage degree of both $-\mathrm{RO}_{\mathrm{ads}}$ and $\mathrm{OH}_{\text {ads. }}$. High $\mathrm{OH}^{-}$concentration in bulk electrolyte will increase $\mathrm{OH}_{\text {ads }}$ on Pt catalyst surface. Third, it was reported that high $\mathrm{pH}$ would benefit the initial dehydrogenation of alcohol. ${ }^{75}$ Therefore, high $\mathrm{OH}^{-}$concentration will promote the generation of alkoxy intermediate adsorbed on Pt catalyst surface by lowing the activation energy barrier. ${ }^{76}$ As 
a result, faster reaction kinetics will be achieved in a higher $\mathrm{pH}$ electrolyte. This is evidenced by the lower anode overpotential observed in a higher $\mathrm{KOH}$ concentration electrolyte.
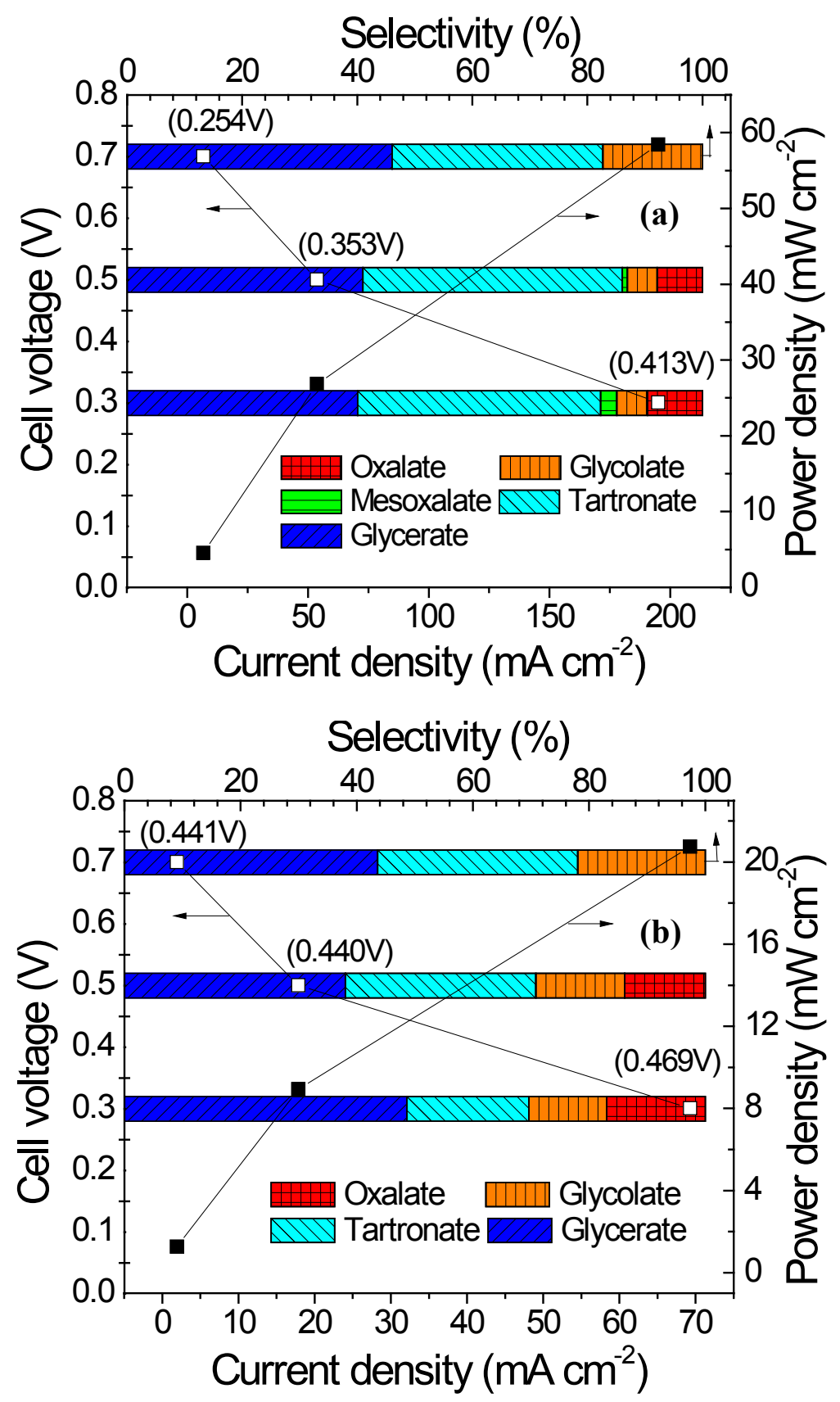

Fig. 7.5 Electricity generation and product distribution from electro-catalytic oxidation of glycerol in AEMFC with $1.0 \mathrm{M}$ glycerol + (a) $4.0 \mathrm{M} \mathrm{KOH}$ and (b) $0.5 \mathrm{M} \mathrm{KOH}$ fuel for an operation duration of 2 hours, anode overpotential ( $v s$. SHE) was marked in parenthesis. The cell operation temperature was $50^{\circ} \mathrm{C}$. 
As the $\mathrm{O}-\mathrm{H}$ bond activation barrier is greatly reduced in high $\mathrm{pH}$ media, ${ }^{76}$ it is more favorable to oxidize hydroxyl group to carboxyl other than break $\mathrm{C}-\mathrm{C}$ bond. Therefore, higher concentrations of $\mathrm{KOH}$ have been found to slightly benefit the $\mathrm{C}_{3}$ products formation. When $0.5 \mathrm{M} \mathrm{KOH}$ was used (Fig. 7.5 (b)), the $\mathrm{C}_{3}$ products selectivity varies from $70-78 \%$ with the fuel cell voltage from 0.7 to $0.3 \mathrm{~V}$. As $\mathrm{KOH}$ concentration increased to $2.0 \mathrm{M}$ (Fig. 7.4 (a)), the $\mathrm{C}_{3}$ products selectivity is $79-84 \%$. When the $\mathrm{KOH}$ increased to $4.0 \mathrm{M}$ (Fig. 7.5 (a)), the $\mathrm{C}_{3}$ products selectivity is $83-87 \%$. As the $\mathrm{O}-\mathrm{H}$ bond activation barrier drops in higher $\mathrm{pH}$ media, mesoxalate production, which requires the oxidation of the secondary hydroxyl, was observed even at the operation voltage of $0.5 \mathrm{~V}$ in the 4.0 M KOH $+1.0 \mathrm{M}$ glycerol test. On the contrary, when $0.5 \mathrm{M} \mathrm{KOH}+1.0$ M glycerol was used, no mesoxalate was collected even at the fuel cell operation voltage of $0.3 \mathrm{~V}$, indicating a strong $\mathrm{KOH}$ concentration effect on the product selectivity.

\subsubsection{Effects of glycerol concentration}

Since glycerol oxidation is related to both $-\mathrm{RO}_{\mathrm{ads}}$ and $\mathrm{OH}_{\mathrm{ads}}$ coverage degree on the $\mathrm{Pt}$ catalyst surface, when glycerol concentration decreased from $2.0 \mathrm{M}$ to $0.1 \mathrm{M}$, both the current density and power density remarkably decreased, and the anode overpotential shifted positively. As shown in Fig. 7.6 and Table 7.1, glycerol concentration strongly affects the glycerol conversion rate. Due to the reduced amount (concentration) of glycerol, glycerol conversion in $2.0 \mathrm{M} \mathrm{KOH}+0.1 \mathrm{M}$ glycerol is higher than that obtained in $2.0 \mathrm{M} \mathrm{KOH}+1.0 \mathrm{M}$ glycerol. This is especially apparent at a fuel cell operation voltage of $0.3 \mathrm{~V}$, where the glycerol conversion could reach $63.7 \%$, which is 3 times of that observed in $1.0 \mathrm{M}$ glycerol $(21.5 \%)$. The limitation of fuel feeding also affects the product selectivity. At the cell voltage of $0.7 \mathrm{~V}$, a high tartronate selectivity of $50 \%$ and a total $\mathrm{C}_{3}$ products selectivity of $91 \%$ were achieved. As the cell voltage decreased to $0.3 \mathrm{~V}$, the total $\mathrm{C}_{3}$ products selectivity decreased to $62 \%$, while the glycerate dropped to $21 \%$. However in the meantime, very high mesoxalate and oxalate selectivities reached $7 \%$ and $28 \%$, respectively. This indicates that with a low glycerol concentration, the high output 
power density at $0.3 \mathrm{~V}$ requires deeper oxidation of glycerol, resulting in high mesoxalate (fully oxidized $\mathrm{C}_{3}$ product) and oxalate (fully oxidized $\mathrm{C}_{2}$ product) selectivities.

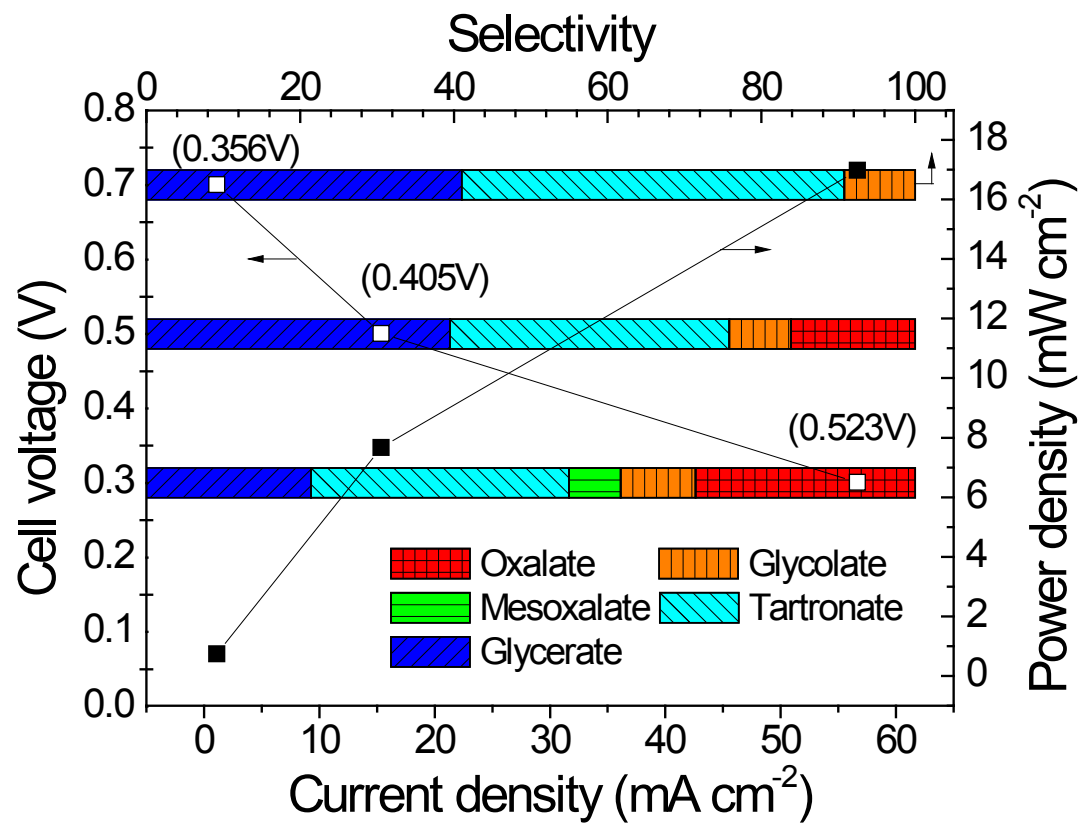

Fig. 7.6 Electricity generation and product distribution from electro-catalytic oxidation of glycerol in AEMFC with 2.0 M KOH $+0.1 \mathrm{M}$ glycerol as the fuel for an operation duration of 2 hours, anode overpotential (vs. SHE) marked in parenthesis. The cell operation temperature was $50^{\circ} \mathrm{C}$.

\subsubsection{Stability of $\mathrm{Pt} / \mathrm{C}$ anode catalyst}

The stability of $\mathrm{Pt} / \mathrm{C}$ catalyst was determined through ten 2-hour runs of glycerol oxidation with 2.0 M KOH $+1.0 \mathrm{M}$ glycerol under the same test conditions. The fuel cell operation voltage was kept at $0.1 \mathrm{~V}$, at which the anode catalyst suffers the highest overpotential and the fuel cell generate the greatest current density. The cathode catalyst loading was increased to $1.3 \mathrm{mg} \mathrm{cm}^{-2}$ to minimize the effect of cathode catalyst activity decreasing. After each run, the anode was cleaned by flushing with de-ionized water until the OCV drops down to $0.01 \mathrm{~V}$. As is shown in Fig. 7.7, the selectivity to each product also almost kept constant during the ten runs of stability tests, which demonstrates a stable selective catalytic activity of $\mathrm{Pt} / \mathrm{C}$ during repetitively operations. In the meantime, 
the $\mathrm{Pt} / \mathrm{C}$ also presents a high stability against deactivation. The glycerol conversion dropped slightly from $39.4 \%$ to $37.6 \%$ after the first run, and stabilized at $32-33 \%$ after four consecutive runs. The $\mathrm{Pt} / \mathrm{C}$ catalyst maintained $81.2 \%$ of its initial catalytic activity after 10 runs (a total 20 hours of operation), indicating an excellent stability and reusability of the $\mathrm{Pt} / \mathrm{C}$ for anode catalyst of the AEM-DGFC.

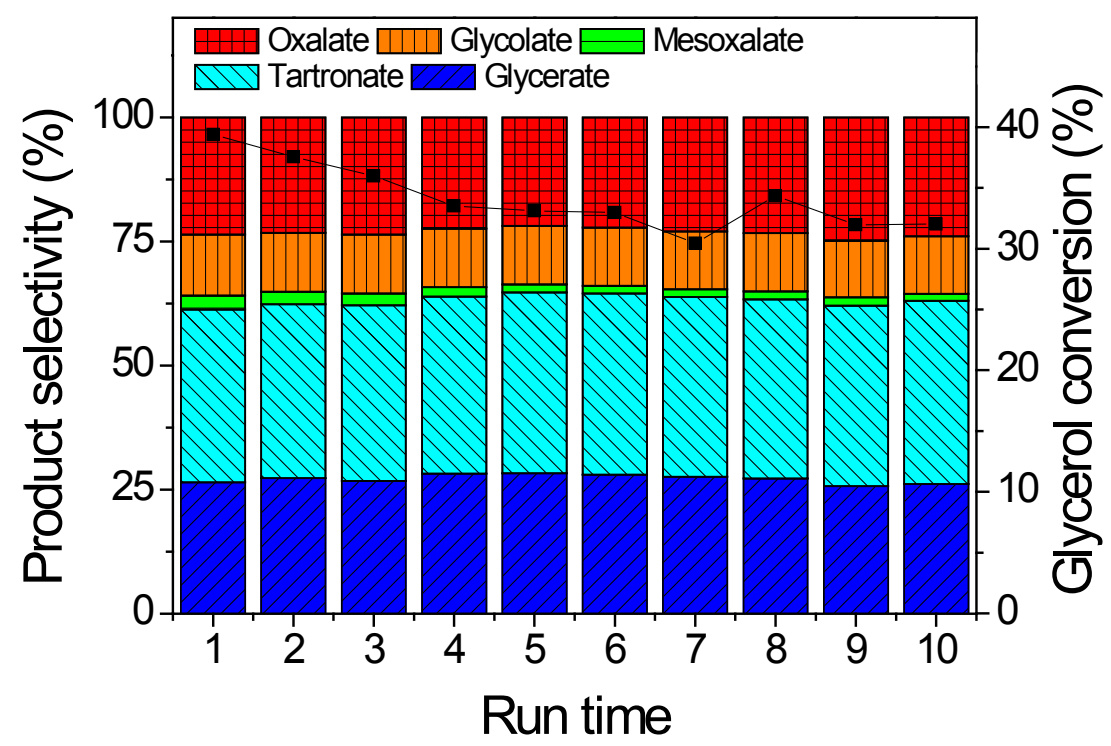

Fig. 7.7 Reusability results of Pt/C catalyst in AEM-DGFC with $2.0 \mathrm{M} \mathrm{KOH}+1.0 \mathrm{M}$ glycerol at the cell operation voltage of $0.1 \mathrm{~V}$, cathode: $\mathrm{Fe}-\mathrm{Cu}-\mathrm{N}_{4} / \mathrm{C}$ (Acta 4020$) 1.3 \mathrm{mg}$ $\mathrm{cm}^{-2}$, reaction time: 2 hours, cell operation temperature: $50^{\circ} \mathrm{C}$.

\subsubsection{Reaction sequence of electro-oxidation of glycerol on $\mathrm{Pt} / \mathrm{C}$ in half cell}

The combination of half cell voltammetry techniques with HPLC analysis to study the kinetics and mechanism of glycerol electro-oxidation was reported by Lamy's group in the 1990s. However, due to the large gap in timescales of these two analysis methods, Lamy's early research is limited to studying reaction products in long-time electrolysis. ${ }^{232}$ Recently, Koper's group developed an online collection offline HPLC analysis system, 
through which the glycerol electro-oxidation products on polycrystalline $\mathrm{Pt}$ and $\mathrm{Au}$ electrode surface were continuously collected under different potentials during a linear voltammetry scan in dilute glycerol solution (e.g. $0.1 \mathrm{M} \mathrm{NaOH}+0.1 \mathrm{M}$ glycerol), and analyzed thereafter by HPLC. ${ }^{72,74}$ In light of Koper's work, a similar sample collection set-up was designed and employed in linear staircase scans on supported Pt nanoparticle catalyst in both $0.1 \mathrm{M} \mathrm{KOH}+0.1 \mathrm{M}$ glycerol and $1.0 \mathrm{M} \mathrm{KOH}+1.0 \mathrm{M}$ glycerol, with a potential increment of $100 \mathrm{mV} 10 \mathrm{~min}^{-1}$. The goal was to investigate the reaction sequence of glycerol oxidation on supported Pt catalysts with high concentration fuel solution.

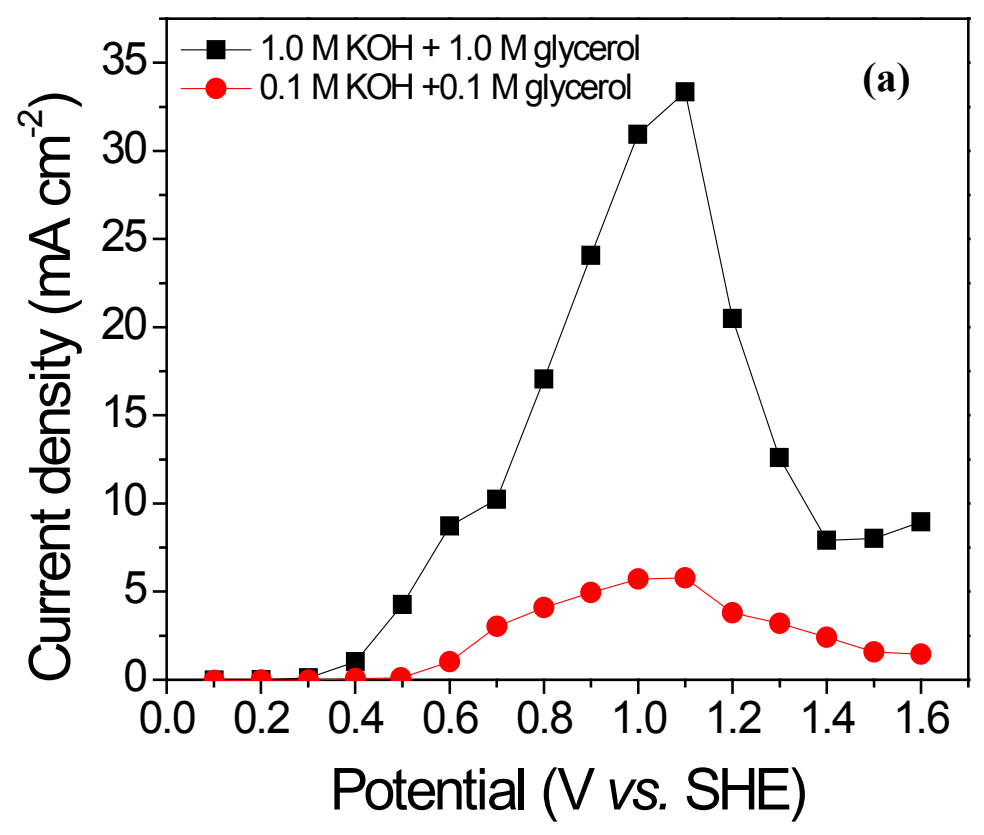



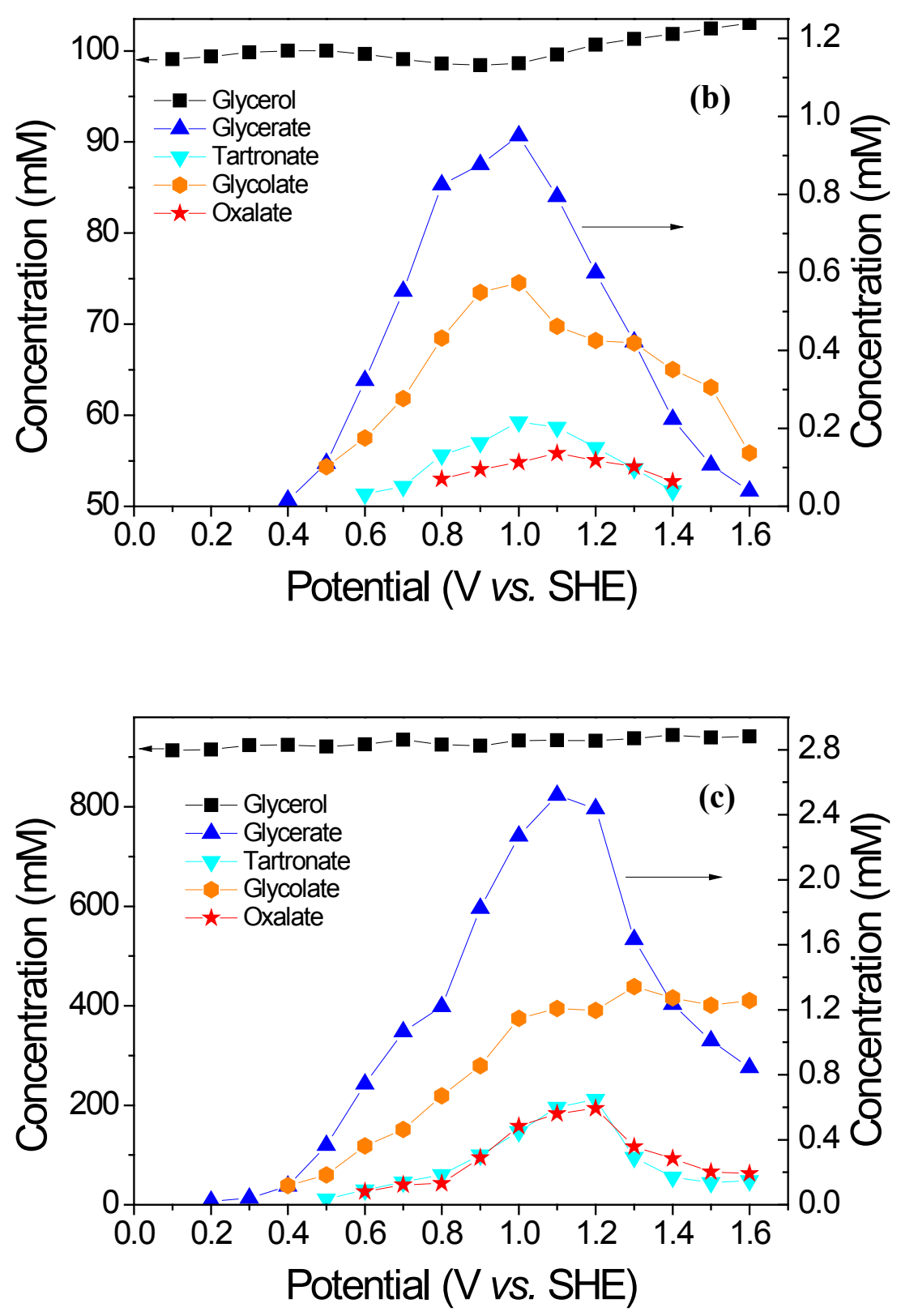

Fig. 7.8 Electro-catalytic oxidation of glycerol on Pt/C catalyst: (a) polarization curves in $0.1 \mathrm{M} \mathrm{KOH}+0.1 \mathrm{M}$ glycerol and 1.0 M KOH $+1.0 \mathrm{M}$ glycerol, and oxidation products concentration profiles in (b) $0.1 \mathrm{M} \mathrm{KOH}+0.1 \mathrm{M}$ glycerol and (c) $1.0 \mathrm{M} \mathrm{KOH}+1.0 \mathrm{M}$ glycerol.

The polarization curves are shown in Fig. 7.8 (a). The current generation started at $0.4 \mathrm{~V}$, with a peak current at $1.1 \mathrm{~V}$ in $0.1 \mathrm{M} \mathrm{KOH}+0.1 \mathrm{M}$ glycerol. A steep drop in current density was observed at potential $>1.1 \mathrm{~V}$, which is due to the deactivation caused by the 
oxidation of surface Pt. When the concentration of $\mathrm{KOH}$ and glycerol increased to $1.0 \mathrm{M}$, the onset potential negatively shifted to $0.2 \mathrm{~V}$, while the peak current density increased to $33.4 \mathrm{~mA} \mathrm{~cm}{ }^{-2}$, which is 6 times higher than that evidenced in $0.1 \mathrm{M} \mathrm{KOH}+0.1 \mathrm{M}$ glycerol $\left(5.8 \mathrm{~mA} \mathrm{~cm}^{-2}\right)$. This indicated higher kinetics could be achieved in higher $\mathrm{KOH}$ and glycerol concentrations, which is in good agreement with the single AEMFC results.

The oxidation products under each applied potential were collected by a needle positioned within $0.5 \mathrm{~mm}$ to the center of the working electrode with a collection rate of $50 \mu 1 \mathrm{~min}^{-1}$. The concentration profiles for $0.1 \mathrm{M} \mathrm{KOH}+0.1 \mathrm{M}$ glycerol and $1.0 \mathrm{M} \mathrm{KOH}$ $+1.0 \mathrm{M}$ glycerol are summarized in Fig. 7.8 (b) and (c), respectively. As only small amount of catalyst was deposited on the glassy carbon electrode, the diffusion issue is negligible as compared with that in single cell. Therefore, the samples collected from the half cell could be used to present the instantaneous products concentration around the catalyst surface. As shown in Fig. 7.8 (b), the oxidation products were detected in the sequence of glycerate, glycolate, tartronate, and oxalate. This observation agrees with the results on polycrystalline platinum disk recently studied by Koper's group, ${ }^{72}$ indicating that glycerol oxidation sequence on supported Pt nanoparticle catalyst is similar to that on the bulk polycrystalline platinum electrode. The products sequence in the half cell is also in agreement with the products distribution examined from the fuel cell reactor, where oxalate is the product that was not found at relatively low anode overpotential. The product concentration profile in Fig. 7.8 (b) shows a volcano shape on each product, with glyceric acid having the highest concentration in low potentials. However, different from what Kwon has reported, at potentials $>1.3 \mathrm{~V}$, the concentration of glycolate in the collected samples exceeded that of glycerate, suggesting that the $\mathrm{C}-\mathrm{C}$ bond cleavage dominates on the PtO surface.

As both $\mathrm{KOH}$ and glycerol concentrations increased to $1.0 \mathrm{M}$, the product concentration profile is shown in Fig. 7.8 (c). While the oxidation products were detected in the same sequence as that in $0.1 \mathrm{M} \mathrm{KOH}+0.1 \mathrm{M}$ glycerol, the initial detected potential for each product moved negatively, and the product concentration collected at each potential increased significantly. This indicates that a higher catalyst reactivity is achieved in a 
concentrated electrolyte. The effect of fuel concentration has also been observed in AEM-DGFC tests: at high concentrations of glycerol or $\mathrm{KOH}$, the anode overpotential decreased and the power density increased.

However, there are still some inconsistences between these two electro-catalytic reaction systems. In the AEM-DGFC test with $2.0 \mathrm{M} \mathrm{KOH}+1.0 \mathrm{M}$ glycerol, tartronate and oxalate were observed at anode overpotential of 0.281 and $0.350 \mathrm{~V} v s$. SHE, respectively. These anode overpotentials are much lower than the 'initial' detected potentials in half cell (tartronate at $0.5 \mathrm{~V}$, oxalate at $0.6 \mathrm{~V}$, vs. SHE, in $1.0 \mathrm{M} \mathrm{KOH}+1.0 \mathrm{M}$ glycerol). At the same time, the concentration of tartronate in the AEM-DGFC is much higher than that in the half cell. No mesoxalate was detected in our half cell tests, nor in previous published work by FTIR, ${ }^{240}$ or by HPLC. ${ }^{72,74}$ Three possible reasons may explain these discrepancies. First, the molar ratio of glycerol to catalyst in the AEM-DGFC (2.0 M $\mathrm{NaOH}+1.0 \mathrm{M}$ glycerol) is $2146: 1$ (mol:mol), which is 57 times smaller than the ratio in the half cell test in $1.0 \mathrm{M} \mathrm{KOH}+1.0 \mathrm{M}$ glycerol (121928:1). The higher catalyst loading in AEM-DGFC leads to a thicker catalyst layer and causes some diffusion difficulty. Therefore, some glycerol and glycerol oxidation intermediates could be trapped in the diffusion and catalyst layers, which may lead to formation of deeper oxidized products, i.e. tartronate and mesoxalate. The deeper oxidized product, tartronate, has also been reported in previous publication of electrolysis of glycerol, in which a glycerol to catalyst ratio similar to ours was employed. ${ }^{275}$ Secondly, the product concentration profile obtained from the half cell tests represents the instantaneous local products concentration around the Pt catalyst, which is not an equilibrated product distribution. However, the products distribution in the AEM-DGFC is the stable bulk concentration after a long reaction time. Thirdly, the tartronate was produced much greater in the AEM-DGFC than in the half cell. As shown in Fig. 5, increasing the base concentration will lead to the products generated at a lower potential. Therefore, when the $\mathrm{KOH}$ concentration further increases to $2.0 \mathrm{M}$, it is possible that these deeper-oxidized products are generated on dense catalyst nanoparticles at even lower potentials. Higher concentration of tartronate will lead to its further oxidation to mesoxalate in the AEM-DGFC reaction environment. The inconsistencies between these two systems imply that glycerol oxidation reactors and 136 
processes may strongly influence the products distribution. The unique catalytic environment in AEM-DGFC may offer unique opportunities to selectively generate deeper- oxidized products, which have not been detected in previous half cell tests, and are difficult to be produced through heterogeneous catalytic oxidation processes.

\subsection{Conclusion}

In summary, an organic solution phase reduction method was used to prepare $\mathrm{Pt} / \mathrm{C}$ catalysts with a small diameter of $2.4 \mathrm{~nm}$ and a narrow size distribution of $1-4 \mathrm{~nm}$. The $\mathrm{Pt} / \mathrm{C}$ catalyst has demonstrated unique electro-catalytic function towards cogeneration of both electricity $\left(124.5 \mathrm{~mW} \mathrm{~cm}^{-2}\right.$ at $\left.80^{\circ} \mathrm{C}\right)$ and valuable chemicals $\left(91 \% \mathrm{C}_{3}\right.$ acids selectivity at $0.7 \mathrm{~V}, 2.0 \mathrm{M} \mathrm{KOH}+1.0 \mathrm{M}$ glycerol), as well as excellent stability in AEMDGFC. Compared to heterogeneous catalytic oxidation of glycerol in traditional batch reactors, our study showed unique fuel cell operation voltage (anode overpotential) regulated product distributions: high tartronate selectivity $(50 \%$ at $0.7 \mathrm{~V}, 2.0 \mathrm{M} \mathrm{KOH}+$ $0.1 \mathrm{M}$ glycerol). In addition, the fully oxidized $\mathrm{C}_{3}$ acid- mesoxalate with the highest selectivity of $7 \%(0.3 \mathrm{~V}, 2.0 \mathrm{M} \mathrm{KOH}+0.1 \mathrm{M}$ glycerol $)$ was first reported on metallic catalyst in high $\mathrm{pH}$ media. The reaction mechanism study based on glycerol oxidation in half-cell using an online collection, offline HPLC analysis technique indicates a similar glycerol oxidation sequence as revealed in AEM-DGFC. However, the inconsistencies between the two systems still exist, possibly due to the quite different reaction environments, such as electrode structure, glycerol: catalyst ratio, and residence time of reactants. 


\section{Chapter 8 Potential regulated electro-oxidation of glycerol to value-added products on supported Au catalysts*}

\subsection{Introduction}

\subsubsection{Background}

Recently, glycerol attracts immense research interests as a biorenewable feedstock with a low price. ${ }^{14}$ As a highly functionalized polyol, glycerol plays a crucial role in the future biorefineries. Its oxygenated derivatives, dihydroxyacetone, glyceric acid, tartronic acid, mesoxalic acid, and glycolic acid, et al, all have practical value. Among these valueadded products, tartronic acid is used in pharmaceuticals for osteoporosis and obesity. It is also used as an anti-corrosive agent in high temperature applications and as an oxygen scavenger in the food industry. ${ }^{276}$ Mesoxalic acid is found to be used in the treatment of diabetes, and also has potential applications as a complexing agent and as a precursor to synthesize 4-chlorophenylhydrazoned mesoxalic acid, which is demonstrated as an antiHIV agent. ${ }^{277}$ Glycolic acid has a broad range of cleanser applications due to its high acidity (pKa 3.83) and chelation properties with metal ions. ${ }^{21,278,279}$ It is also widely used in textile dyeing, leather tanning, personal care products, and the preparation of polyglycolic acid (PGA), which is a macromolecule for dissolvable sutures, ${ }^{280}$ drug delivery materials, ${ }^{281,282}$ and gas barrier packaging materials. ${ }^{283}$

*The material contained in this chapter was previously published in Green Chemistry, 2012, 14, Zhiyong Zhang, Le Xin, Ji Qi, Zhichao Wang, and Wenzhen Li, "Selective electro-conversion of glycerol to glycolate on carbon nanotube supported gold catalyst", 2150-2152. Reproduced by permission of The Royal Society of Chemistry. Copyright 2012 The Royal Society of Chemistry. 
However, up until now, tartronic acid is mainly produced by a non-environment-benign stoichiometric oxidation of maleic acid with permanganate as the oxidizing agent. Mesoxalic acid is mainly synthesized through the hydrolysis of alloxan with baryta water, hydrolysis of caffuric acid with lead acetate, and stoichiometric oxidation of glycerol diacetate with concentrated nitric acid. The out-of-date production methods lead to the extremely high prices of these chemicals, which strongly restricts the potential application of tartronic and mesoxalic acids. Meanwhile, glycolic acid has mainly been

produced by the acid-catalyzed reaction of formaldehyde and carbon monoxide, ${ }^{284-288}$ or by hydrolysis of glycolonitrile (a production from formaldehyde and hydrogen cyanide), ${ }^{279,289-291}$ both of which involve highly toxic chemicals in the processes. It is urgent to develop more efficient, eco-benign, and renewable processes to selectively convert cheap biomass waste glycerol into these valuable chemicals.

\subsubsection{Glycerol oxidation on Au-based catalyst}

Although bulk $\mathrm{Au}$ is one of the most inert/stable metallic materials in the world, the development of nano-technologies has found that the nanoscaled $\mathrm{Au}$ is exceptionally active as a catalyst. As a result, the Au catalysis has emerged as one of the most exciting research areas in chemistry. ${ }^{292,293}$ The aqueous-phase oxidation of glycerol by using molecular oxygen has been extensively studied over $\mathrm{Au}^{17,18,75,242,244,248,249,264}$ and its bimetallic alloys, such as $\mathrm{AuPt}^{262}$ and AuPd. ${ }^{254,265,267,268,294}$ While Au shows no catalytic activity towards glycerol oxidation in acidic environments, it has demonstrated a unique ability to enhance the selectivity to glycerate in alkaline media. Hutchings and his coworkers reported a $100 \%$ selectivity to glycerate at $54-56 \%$ glycerol conversions under optimized conditions. ${ }^{17}$ Parti's group reported that on $\mathrm{Au} / \mathrm{TiO}_{2}$ catalyst, the second primary hydroxyl group will be oxidized, resulting in a tartronate selectivity of $28 \%$. In addition, $\mathrm{H}_{2} \mathrm{O}_{2}$ was also employed as the oxidant instead of molecular $\mathrm{O}_{2}$, which improved the selectivity to glycolate. ${ }^{21,75}$ The influence of the Au particle size has been investigated separately by several groups. ${ }^{248,294}$ Small Au particles are found to have a higher initial activity, but suffer from poor durability. Conversely, larger Au particles are 
less active but have a more-stable reactivity. Until now, the predominant products from direct glycerol oxidation on $\mathrm{Au}$ catalysts in the aqueous alkaline phase have been glycerate and glycolate, whereas the selectivity to tartronate has typically been $<30 \%$ and no mesoxalate has been reported.

\subsubsection{Cogeneration of value-added chemicals and electricity in Au-anode AEM-DGFC}

Although some in-situ FTIR investigations have demonstrated the formation of tartronate and mesoxalate on the surface of the Au catalyst in the course of the glycerol electrooxidation process, ${ }^{216,240}$ it is hard to detect them in the bulk electrolyte. ${ }^{72,74}$ Recently, in a Au-anode $\left(5.0 \mathrm{mg}_{\mathrm{Au}} \mathrm{cm}^{-2}\right.$ ) AEM-DGFC, our group successfully demonstrated that tartronate and mesoxalate can be cogenerated with electrical energies. ${ }^{238}$ At the fuel cell operation voltage of $0.3 \mathrm{~V}$, a $19 \%$ selectivity to tartronate and a $46 \%$ selectivity to mesoxalate were obtained together with a power density of $22.7 \mathrm{~mW} \mathrm{~cm}^{-2}$. Similar to the case of Pt-anode AEM-DGFC, the product distributions in a Au-anode AEM-DGFC are also strongly related with the cell operation voltage and the anode overpotentials. However, restricted by the design and nature of fuel cell, the anode overpotential is not directly controlled, and will increase at higher glycerol consumptions. In addition, the anode overpotential is narrowed by the theoretical AEM-DGFC voltage and the huge cathode overpotential. The highest anode overpotential obtained in this research is only $0.633 \mathrm{~V} v s$. SHE.

To more accurately study the effects of potential on the selective electro-oxidation of glycerol and over a wider potential range, in this chapter, two kinds of electro-catalytic conversion reactors were designed. Based on a flow plate design with an active area of 5 $\mathrm{cm}^{2}$, which is similar to the fuel cell reactor, the potential regulated oxidation of glycerol to tartronate and mesoxalate was accurately studied in the low potential range. The investigation clearly demonstrated a switch potential of $0.45 \mathrm{~V}$ from tartronate to mesoxalate. In order to study the glycerol electro-oxidation at higher potentials, an 
electro-catalytic reactor with a smaller active area of $1 \mathrm{~cm}^{-2}$ was designed. The result shows that while the lower applied potentials favor the generation of continuous oxidation of $-\mathrm{OH}$ products (either tartronate or mesoxalate), the higher potentials lead to a high selectivity to C-C bond cleavage product (glycolate).

\subsection{Experimental}

\subsubsection{Preparation of $\mathrm{Au} / \mathrm{C}$ and $\mathrm{Au} / \mathrm{CNT}$ catalysts}

$151.7 \mathrm{mg}$ of $\mathrm{AuCl}_{3}(0.5 \mathrm{mmol})$ was first dissolved in a mixture of $16 \mathrm{ml}$ of octadecene and $4 \mathrm{ml}$ of oleylamine under a nitrogen flow. The system was then rapidly heated to $80^{\circ} \mathrm{C}$, followed by a quick injection of $1.5 \mathrm{ml}$ of $\mathrm{LiBEt}_{3} \mathrm{H}$. After holding the temperature for 10 minutes, the Au nanoparticles (NPs) were achieved after quickly cooling down the solution to room temperature and separated by centrifugation.

The as-prepared Au-NPs were then dispersed into $50 \mathrm{ml}$ of Hexanes and slowly dropped into an ethanol solution of carbon black $(148.0 \mathrm{mg})$. The final product $\mathrm{Au} / \mathrm{C}$ catalyst (40 wt $\%$ ) was obtained after the filtration and washed with copious amounts of ethanol.

The surface of CNT was functionalized in a $4.0 \mathrm{~N} \mathrm{H}_{2} \mathrm{SO}_{4}-\mathrm{HNO}_{3}$ mixture for 4 hours at $80^{\circ} \mathrm{C} .{ }^{100} \mathrm{~A} 40 \mathrm{wt} \% \mathrm{Au} / \mathrm{CNT}$ catalyst was then prepared following a similar procedure.

\subsubsection{Physical characterizations}

The morphology and structure of $\mathrm{Au} / \mathrm{C}$ and $\mathrm{Au} / \mathrm{CNT}$ catalyst were analyzed by X-ray diffraction (XRD) and transmission election microscopy (TEM). 


\subsubsection{Electro-catalytic oxidation of glycerol}

Two electro-catalytic reactors were designed and fabricated for the investigation of glycerol oxidation at lower and higher potentials, respectively. For the glycerol electrooxidation taking place at lower applied potentials, the reactor was assembled as the scheme shown in Fig. 8.1 (a), with an active cross-sectional area of $5 \mathrm{~cm}^{2}$. At the anode side, a $\mathrm{Au} / \mathrm{C}$ isopropanol ink was directly sprayed on a untreated carbon cloth (Fuel Cell store) liquid diffusion layer to obtain a catalyst loading of $5.0 \mathrm{mg}_{\mathrm{Au}} \mathrm{cm}^{-2}$, while at the cathode side, an untreated carbon cloth with $1.0 \mathrm{mg}_{\mathrm{Pt}} \mathrm{cm}^{-2}$ of Pt/C catalyst was prepared through the same procedure. A solid anion-exchange membrane (FAA, $110 \mu \mathrm{m})$ was employed to separate the anode fuel and cathode electrolyte. The temperature was controlled at $50^{\circ} \mathrm{C}$, which is consistent with that applied in the Au-anode fuel cells in our previous work. ${ }^{238}$ During each run, $8.0 \mathrm{ml}$ of glycerol $\mathrm{KOH}$ electrolyte was introduced into a plastic fuel vessel and pumped into the anode through a closed loop by a peristaltic pump. At the same time, a $\mathrm{KOH}$ solution was cycled through the cathode. $\mathrm{A} \mathrm{Hg} / \mathrm{HgO} / 1.0$ $\mathrm{M} \mathrm{KOH}$ reference electrode was dipped into the anode chamber, through which the anode applied potential was accurately controlled by a potentiostats (Versastat MC, Princeton Applied Research) for a certain reaction time. 

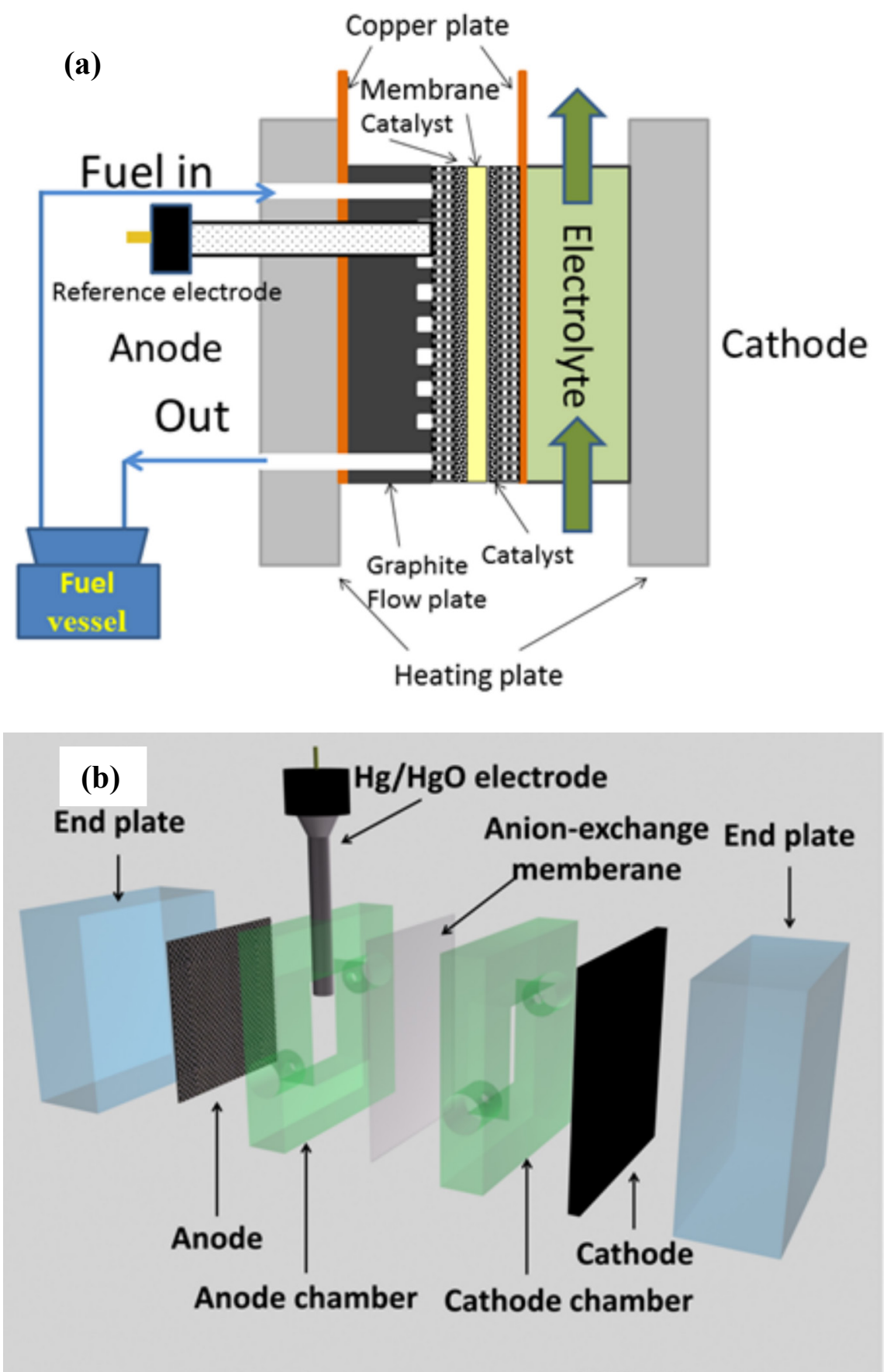

Fig. 8.1 Schematic illustration of the anion exchange membrane-based electro-catalytic reactors.

The glycerol electro-oxidation at higher applied potentials was carried out in the reactor assembled as the scheme in Fig. 8.1 (b). The active area was reduced to $1.0 \mathrm{~cm}^{2}$ in order to avoid the current overload in the potentiostats at the high applied potentials. The anode 
liquid diffusion electrode was prepared by spraying a $\mathrm{Au} / \mathrm{CNT}$ isopropanol ink (containing $10 \mathrm{wt} \%$ of Teflon) onto a treated carbon cloth (Fuel Cell store, containing 10 $\mathrm{wt} \%$ of Teflon), while the cathode and the membrane are kept the same. The reaction was carried out through the same procedure, while room temperature was applied instead of $50^{\circ} \mathrm{C}$. To elucidate the reaction pathway, the oxidation of glycolate and oxalate were also investigated under the same conditions.

\subsubsection{Products analysis}

For glycerol oxidation, the product selectivity is calculated by equation (2-9):

$$
\text { Selectivity }=\frac{\text { Moles of specific product forms }}{\text { Total moles of } C_{2} \text { and } C_{3} \text { products detected }} \times 100 \%
$$

The carbon balance is calculated by the equation (2-11):

$$
\text { Carbon balance }=\frac{M_{G_{i}}-M_{C_{3}}-M_{C_{2}}-M_{G_{f}}}{M_{G_{i}}} \times 100 \%
$$

where $\mathrm{M}_{\mathrm{Gi}}$ and $\mathrm{M}_{\mathrm{Gf}}$ are the initial and final moles of glycerol in the electrolyte, $\mathrm{M}_{\mathrm{C} 3}$ and $\mathrm{M}_{\mathrm{C} 2}$ are the moles of $\mathrm{C}_{3}$ products (glycerate, tartronate, and mesoxalate), and $\mathrm{C}_{2}$ products (glycolate, glyoxylate, and oxalate), respectively. A smaller carbon balance indicates less $\mathrm{C}_{2}$ chemicals were further oxidized to $\mathrm{C}_{1}$ products (formate and carbonate).

For glycolate oxidation, the selectivity was calculated as follows:

$$
\text { Selectivity }=\frac{\text { Moles of specific product forms }}{\text { Total moles of } C_{1} \text { and } C_{2} \text { products detected }} \times 100 \%
$$

The carbon balance was based on:

$$
\text { Carbon balance }=\frac{2 M_{C_{i}}-2 M_{C_{2}}-M_{C_{1}}-2 M_{C_{f}}}{2 M_{C_{i}}} \times 100 \%
$$

If assuming that no formate was further oxidized to carbonate $\left(\mathrm{CO}_{2}\right.$ combined with $\mathrm{OH}^{-}$ in high $\mathrm{pH}$ media) then, 


$$
M_{C_{1}}=M_{C_{F M}}
$$

Therefore:

$$
\text { Carbon balance }=\frac{M_{C_{i}}-M_{C_{2}}-1 / 2 M_{C_{F M}}-M_{C_{f}}}{M_{C_{i}}} \times 100 \%
$$

where $\mathrm{M}_{\mathrm{Ci}}$ and $\mathrm{M}_{\mathrm{Cf}}$ are the initial and final moles of glycolate in the electrolyte. $\mathrm{M}_{\mathrm{C} 2}, \mathrm{M}_{\mathrm{C} 1}$, and $\mathrm{M}_{\mathrm{CFM}}$ are the moles of $\mathrm{C}_{2}$ products (glyoxylate and oxalate), $\mathrm{C}_{1}$ products (formate and carbonate), and formate respectively. A smaller carbon balance indicates less formate was further oxidized to carbonate.

\subsection{Results and discussion}

\subsubsection{Physical characterizations}

The XRD patterns of $\mathrm{Au} / \mathrm{C}$ and $\mathrm{Au} / \mathrm{CNT}$ catalysts are shown in Fig. 8.2. The peak at $25.2^{\circ}$ is assigned to the graphite (002) facet, which is stronger in the XRD pattern of $\mathrm{Au} / \mathrm{CNT}$ due to the high graphite degree of CNT. The average metal crystal sizes of these two catalysts are calculated based on Au (220) diffraction peaks, using the Debye-Scherrer formula (equation (2-1)):

$$
L=\frac{0.9 \lambda_{K \alpha}}{B_{2 \theta} \cos \theta_{\max }}
$$

which yields the results of $2.7 \mathrm{~nm}$ for $\mathrm{Au} / \mathrm{C}$ and $2.6 \mathrm{~nm}$ for $\mathrm{Au} / \mathrm{CNT}$ catalysts.

The TEM images of $\mathrm{Au} / \mathrm{C}$ and $\mathrm{Au} / \mathrm{CNT}$ and their corresponding histograms are shown in Fig. 8.3. It is observed that most of the nanoparticles are round in shape and uniformly dispersed on the supports. The average particle sizes evaluated from the TEM image are 3.5 and $2.5 \mathrm{~nm}$ for $\mathrm{Au} / \mathrm{C}$ and $\mathrm{Au} / \mathrm{CNT}$, respectively, which are in good agreement with the XRD results. The histogram of particle sizes counted from 100 randomly chosen particles show a narrow size distribution for both $\mathrm{Au} / \mathrm{C}$ and $\mathrm{Au} / \mathrm{CNT}$ catalysts, indicating the organic solution phase reduction method has a good control over the Au nanoparticle morphology. 


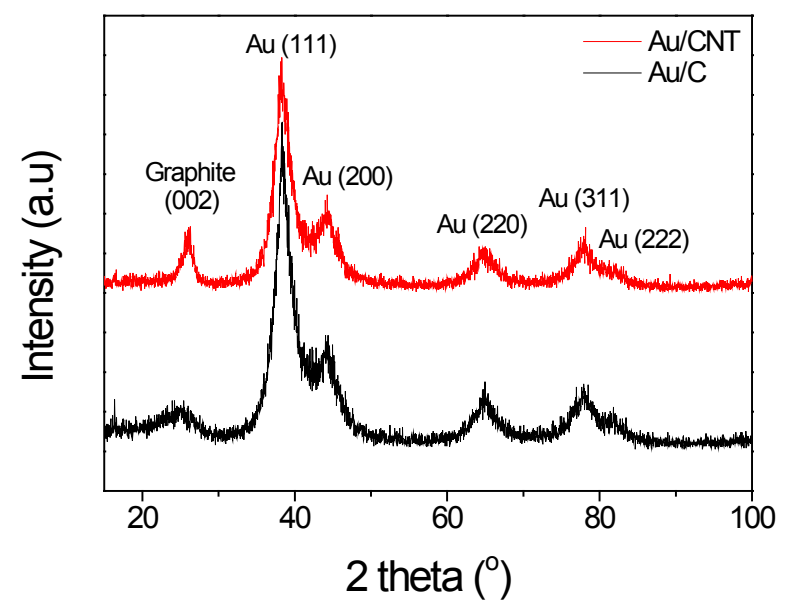

Fig. 8.2 XRD patterns of $\mathrm{Au} / \mathrm{C}$ and $\mathrm{Au} / \mathrm{CNT}$ catalysts.
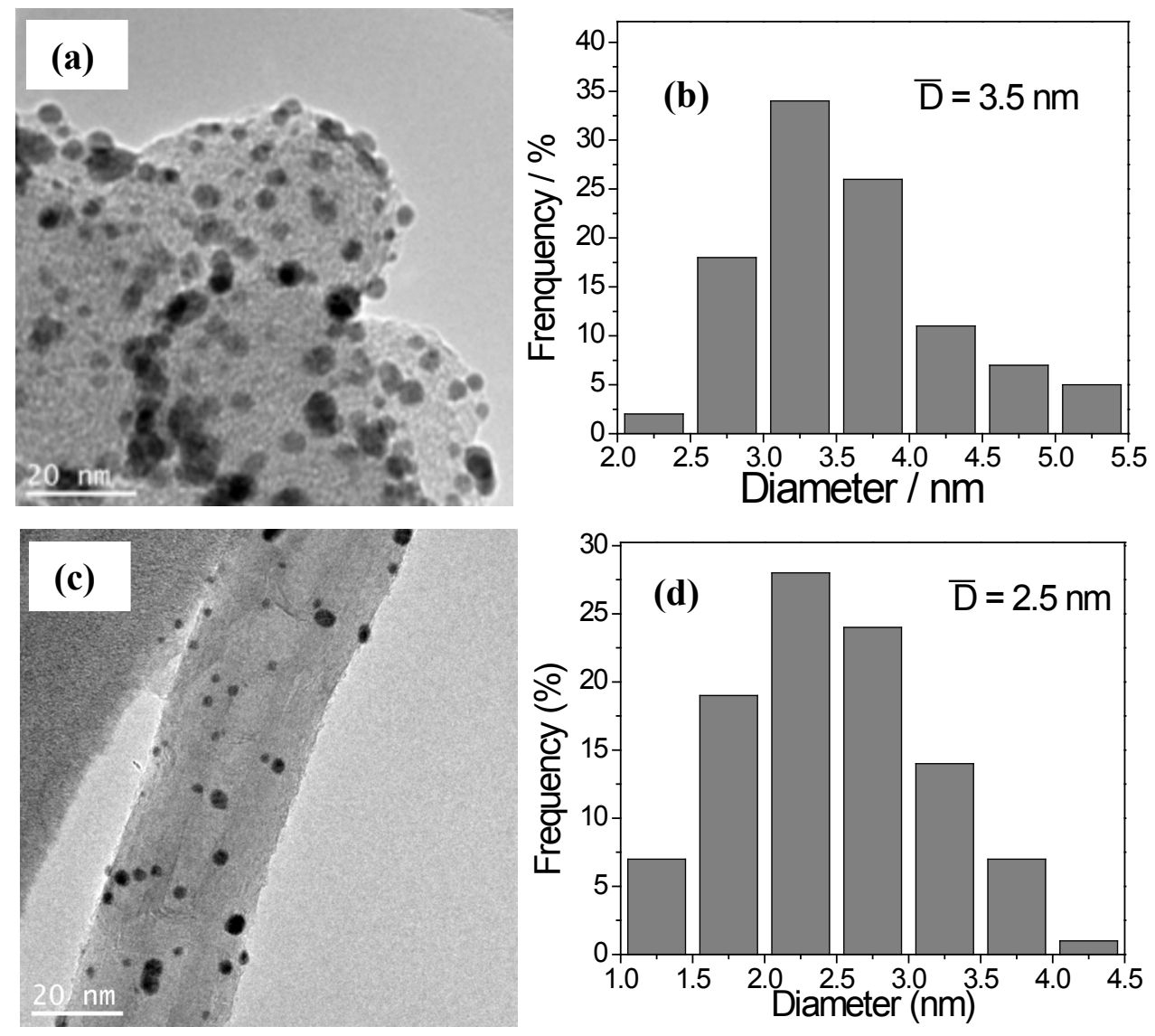

Fig. 8.3 The TEM images of $\mathrm{Au} / \mathrm{C}$ and $\mathrm{Au} / \mathrm{CNT}$ ((a) and (c)), and their corresponding particle-size histograms ((b) and (d)). 


\subsubsection{Potential controlled selective electro-oxidation of glycerol to tartronate and mesoxalate}

The potential controlled oxidation of glycerol at the lower applied potential was investigated in the electro-catalytic reactor illustrated in Fig. 8.1 (a). The product distributions under different applied potentials after 1 hour at $50^{\circ} \mathrm{C}$ were summarized in Fig. 8.4 and clearly demonstrated the selectivity of each product was strongly regulated on the applied potentials. At applied potentials lower than $0.4 \mathrm{~V}$, the main product is tartronate, with a selectivity of $79 \%$, while no mesoxalate was observed. Mesoxalate was obtained from the applied potential of $0.45 \mathrm{~V}$. Its selectivity gradually increased with the increasing of applied potentials, and reached the highest selectivity of $57 \%$ at $0.65 \mathrm{~V}$. In the meantime, the selectivity to tartronate gradually decreased to $26 \%$ (at $0.65 \mathrm{~V}$ ). The trend strongly suggests a potential controlled conversion from tartronate to mesoxalate, which takes place at $0.45 \mathrm{~V}$, and can be further enhanced at higher potentials. When further increasing the anode applied potential to $0.7 \mathrm{~V}$, the selectivity to mesoxaliate decreased to $55 \%$, while the selectivity to oxalate increased from $5 \%$ (at $0.65 \mathrm{~V}$ ) to $8 \%$, indicating some mesoxalate was over-oxidized to oxalate.

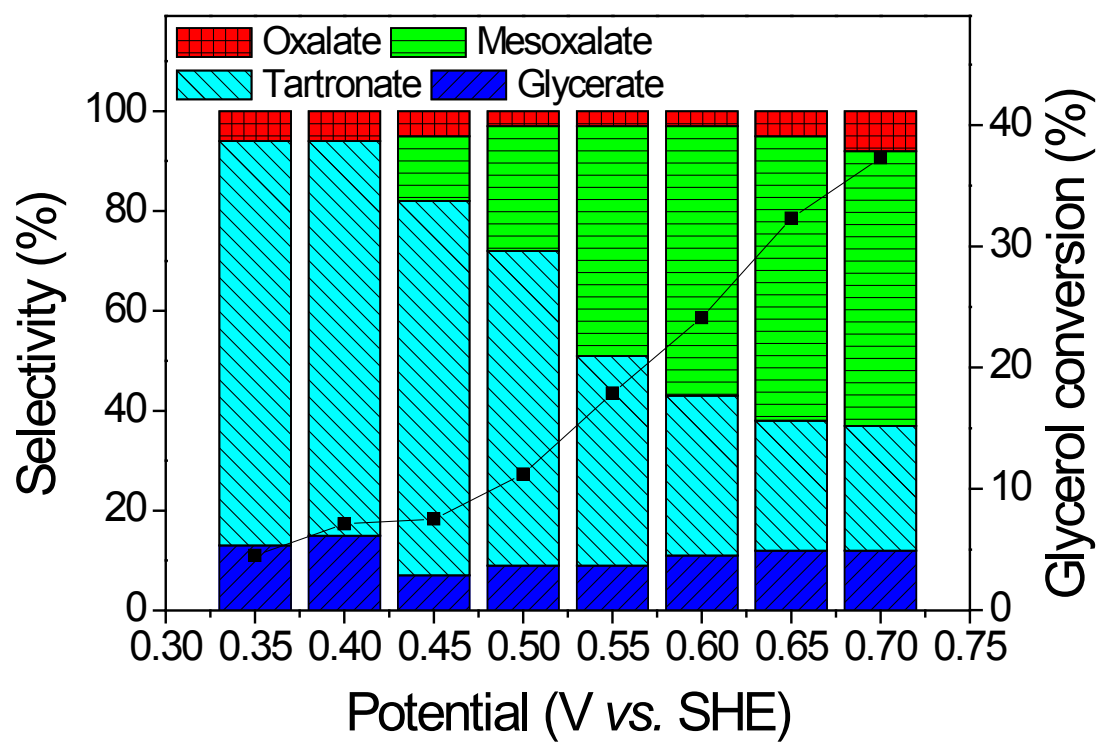

Fig. 8.4 Electro-oxidation of glycerol $(2.0 \mathrm{M} \mathrm{KOH}+1.0 \mathrm{M}$ glycerol $)$ on $\mathrm{Au} / \mathrm{C}$ under different applied potentials for 1 hour at $50^{\circ} \mathrm{C}$. 
The potential-regulation effect was further confirmed at both the lower anode applied potential of $0.4 \mathrm{~V}$ and the higher one of $0.65 \mathrm{~V}$ by elongating the reaction time. As shown in Fig. 8.5 (a), applied with an anode potential of $0.4 \mathrm{~V}$, the glycerol conversion continuously increased with the elongation of reaction time and reached $35 \%$ after 18 hours. However, the selectivity to tartronate still stabilized at $\sim 78 \%$, which implies that the selectivity to tartronate is mainly controlled by the applied potential, and has a limited relationship with the reaction time. It also needs to mention that the selectivity to oxalate slightly increased for a longer reaction time. This is possibly due to the slow oxidation of tartronate to glyoxylate, which is then quickly oxidized to oxalate. No mesoxalate was observed even after 18 hours' reaction, indicating that the oxidation from tartronate to mesoxalate was firmly regulated by the applied potential, and can only take place at potentials higher than $0.45 \mathrm{~V}$ at this specific condition. It is noted that a trace amount of glycolate was observed $(<1 \%)$ after the 18 hours' reaction. Although glycolic acid can be formed from tartronic acid through a non-Faradic decarboxylation process in a nonoxidizing, low $\mathrm{pH}$ environment, ${ }^{21}$ it is not favored on polarized $\mathrm{Au}$ catalysts in an alkaline electrolyte. ${ }^{238}$ Therefore, the observation of a small amount of glycolate after 18 hours of reaction indicates that an oxidation of glycerate to glycolate takes place very slowly at this low applied potential through a C-C bond cleavage.

The potential-regulating effect was also confirmed at a higher applied potential of $0.65 \mathrm{~V}$. Fed with $2.0 \mathrm{M} \mathrm{KOH}+1.0 \mathrm{M}$ glycerol, the selectivities to tartronate and mesoxalate were $26 \%$ and $57 \%$, respectively, while the conversion of glycerol was $32 \%$. When the reaction time increased to 6 hours, the selectivities to tartronate and mesoxalate only slightly decreased to $24 \%$ and $55 \%$, respectively, even at the high glycerol conversion of $78 \%$. This strongly indicates that the selectivity to the main products, tartronate and mesoxalate, is controlled by the applied anode potential, and is only weakly affected by the reaction time or glycerol conversion. The slight decrease in tartronate and mesoxalate selectivities is probably due to the over-oxidation to oxalate, which can be demonstrated by the increase in the selectivity to the byproduct oxalate from $5 \%$ (after 1 hour) to $9 \%$ (after 6 hours). 

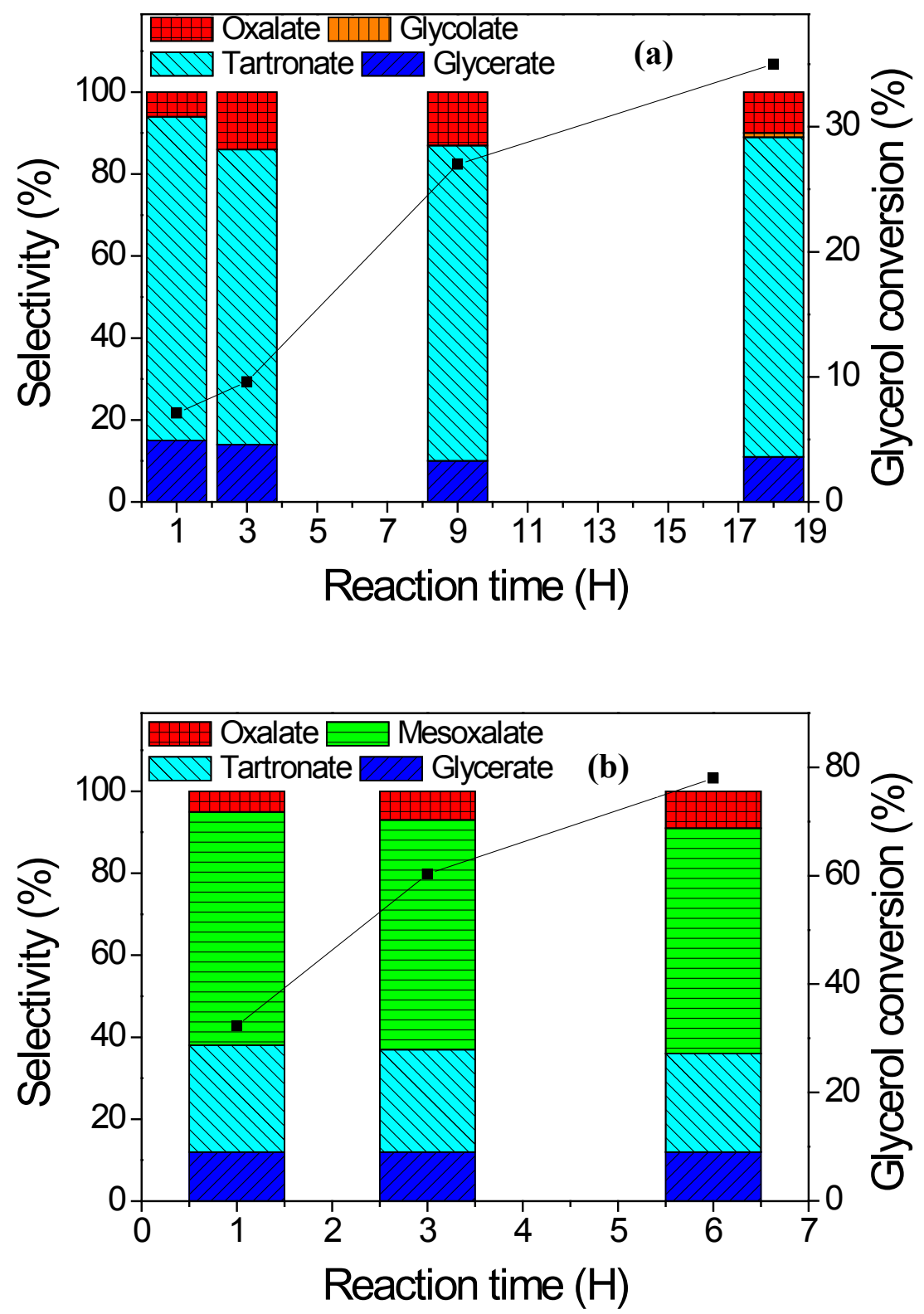

Fig. 8.5 Electro-oxidation of glycerol (2.0 M KOH + 1.0 M glycerol) on $\mathrm{Au} / \mathrm{C}$ under (a) $0.4 \mathrm{~V}$ and (b) $0.65 \mathrm{~V}$ at $50^{\circ} \mathrm{C}$ for different reaction times. 

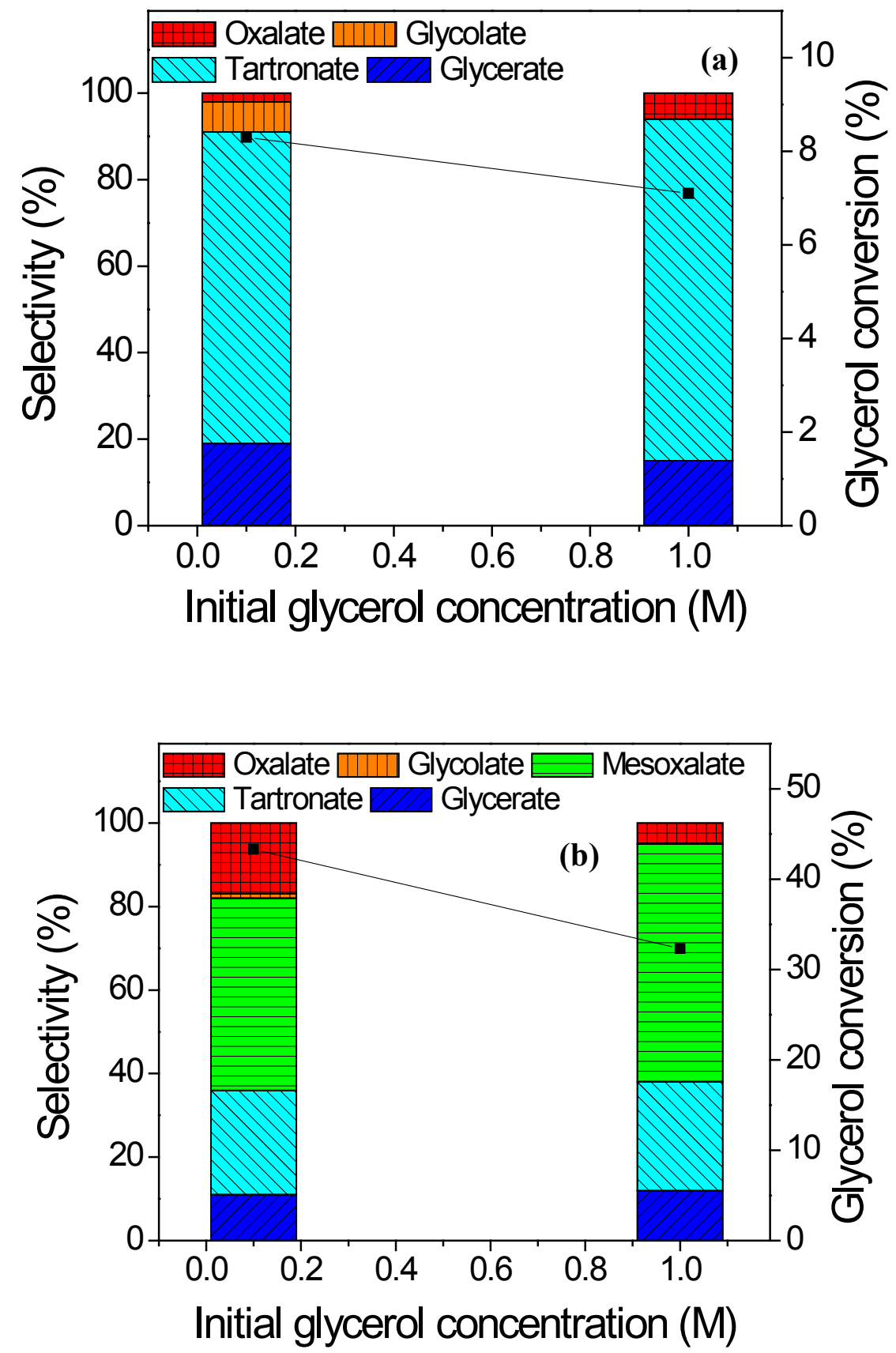

Fig. 8.6 Initial glycerol concentration effects, at the applied potential of (a) $0.4 \mathrm{~V}$ and (b) $0.65 \mathrm{~V}$, in $2.0 \mathrm{M} \mathrm{KOH}$ for 1 hour at $50^{\circ} \mathrm{C}$.

The electro-oxidation of glycerol was investigated with different glycerol initial concentrations, by fixing the $\mathrm{KOH}$ concentration at $2.0 \mathrm{M}$. The results are summarized in Fig. 8.6, which indicate that a lower glycerol initial concentration will increase the 
selectivity to $\mathrm{C}_{2}$ products (glycolate or oxalate). As shown in Fig. 8.6 (a), at the applied anode potential of $0.4 \mathrm{~V}$, in $2.0 \mathrm{M} \mathrm{KOH}+0.1 \mathrm{M}$ glycerol, a selectivity of $7 \%$ to glycolate was observed after 1 hour's reaction. However, when $2.0 \mathrm{M} \mathrm{KOH}+1.0 \mathrm{M}$ glycerol was used, only $<1 \%$ of glycolate was detected even after 18 hours' reaction (Fig. 8.5 (a)). This indicates that a lower glycerol initial concentration will facilitate the oxidation of glycerate to glycolate. The initial glycerol concentration effect was also investigated at the anode applied potential of $0.65 \mathrm{~V}$, at which there was the highest selectivity to mesoxalate after 1 hour's reaction. As shown in Fig. 8.6 (b), when the initial glycerol concentration reduced 1.0 to $0.1 \mathrm{M}$, the selectivity to oxalate increased from $5 \%$ to $17 \%$, while that to mesoxalate decreased from $57 \%$ to $46 \%$, indicating the oxidation of mesoxalate to oxalate was enhanced at a lower initial glycerol concentration. In addition, a trace amount of glycolate was also observed, due to the enhanced oxidation rate of glycerate to glycolate at the lower initial glycerol concentration.

\subsubsection{Selective electro-oxidation of glycerol to glycolate}

Due to the current limitation of the potentiostats, the electro-catalytic reactor was redesigned with an active area of $1.0 \mathrm{~cm}^{2}$ to investigate the electro-oxidation of glycerol at higher applied potentials. CNT is used as the catalyst support instead of carbon black due to its better durability under high potentials. ${ }^{44,98,100,101,165,295-298}$ In addition, $10 \mathrm{wt} \%$ of Teflon was also employed in the catalyst layer to prevent the catalyst loss under high potentials. The product distributions after 3 hours of reaction at room temperature at different applied potentials were summarized in Fig. 8.7. In general, while the lower applied potentials favor the generation of tartronate and mesoxalate, the higher applied potentials have been found to facilitate the $\mathrm{C}_{2}$ products, especially glycolate. At the applied potential of $1.0 \mathrm{~V}$, the selectivity to glycolate was only $41 \%$. However, when the applied potential increased to $1.6 \mathrm{~V}$, the glycolate selectivity increased up to $85 \%$. On the contrary, the selectivity to tartronate gradually decreased from $17 \%$ (at $1.0 \mathrm{~V}$ ) to $4 \%$ (at 1.6 V). This suggests that the higher applied potentials will promote the $\mathrm{C}-\mathrm{C}$ bond cleavage of glycerate to generate glycolate, other than the oxidation of the second 
primary hydroxyl group to tartronate. Meanwhile, at the applied potential of $1.0 \mathrm{~V}$, a glyoxylate selectivity of $2 \%$ was observed, which increased to $4 \%$ at $1.2 \mathrm{~V}$. The observation of glyoxylate indicates the slow conversion from tartronate to glyoxylate at the lower applied potentials has been accelerated at the higher potentials. However, the selectivity to glyoxylate decreased at potentials higher than $1.2 \mathrm{~V}$, which is probably due to the reduction of tartronate selectivity and the enhanced oxidation of glyoxylate to oxalate. No mesoxalate was detected at the higher applied potentials, indicating the fully oxidized $\mathrm{C}_{3}$ product is not a stable product under these conditions. Meanwhile, while the carbon balance of all the tests at lower applied potentials are within $10 \%$, the carbon balance calculated by equation (2-11) slightly increased from $10 \%$ (at $1.0 \mathrm{~V}$ ) to $13 \%$ (at $1.6 \mathrm{~V}$ ), indicating more $\mathrm{C}_{2}$ products (glycolate, glyoxylate, and oxalate) were oxidized to $\mathrm{C}_{1}$ products (formate and carbonate) at the higher applied potentials. To elucidate this mechanism, 1.0 M glycolate was oxidized at $1.6 \mathrm{~V}$ for 3 hours. The results summarized in Fig. 8.8 clearly show the formation of formate, with selectivities of $62 \%$ and $73 \%$ in 2.0 and $1.0 \mathrm{M} \mathrm{KOH}$ electrolytes, respectively. In addition, the corresponding carbon balances were $15 \%$ and $16 \%$, indicating formate may be further oxidized to carbonate. We also considered the oxidation of oxalate in the electro-catalytic reactor. When $2.0 \mathrm{M}$ $\mathrm{KOH}+1.0 \mathrm{M}$ oxalate was employed, a stable anodic current and a carbon balance of $12 \%$ were observed after 6 hours reaction at $1.6 \mathrm{~V}$, indicating that the $\mathrm{C}-\mathrm{C}$ bond cleavage of oxalate also accounts for the formation of carbonate. The glycerol conversions after 3 hours' reaction at each applied potential were within 35\%. This is lower than the glycerol conversion at $0.7 \mathrm{~V}$ after 1 hour's reaction (Section 8.2.2), which is probably due to the reduction in the active area and the reaction temperature. 


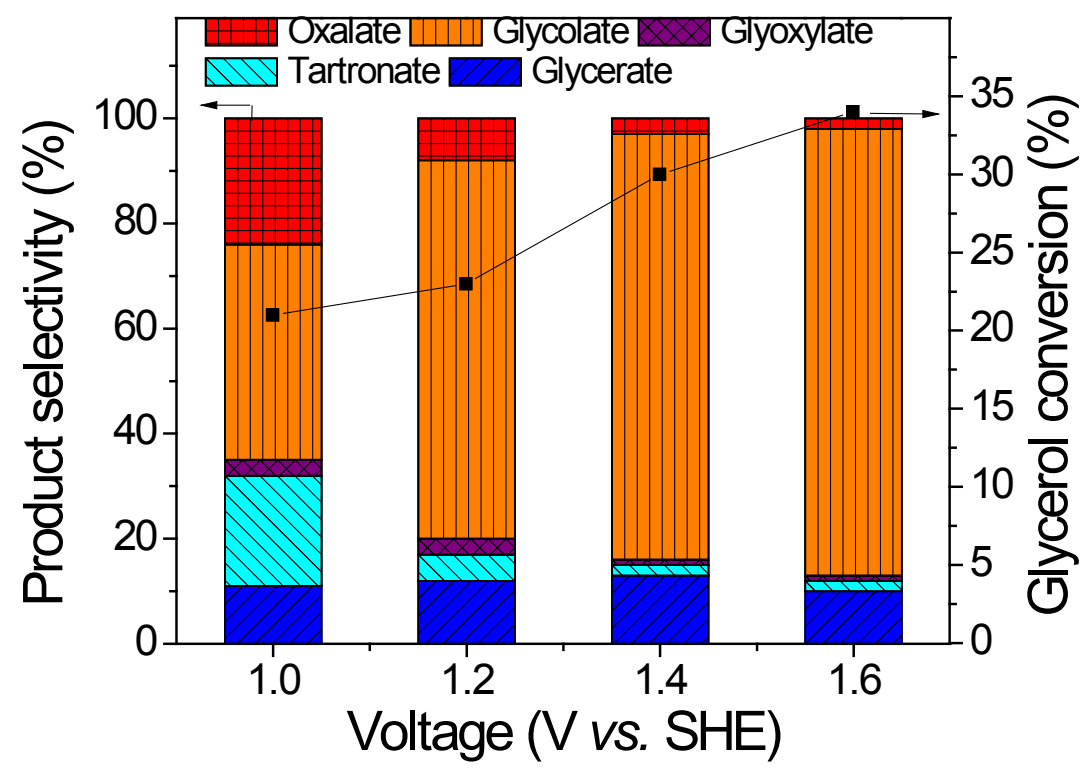

Fig. 8.7 Electro-oxidation of glycerol (2.0 M KOH + 1.0 M glycerol) on Au/CNT under different applied potentials for 3 hours

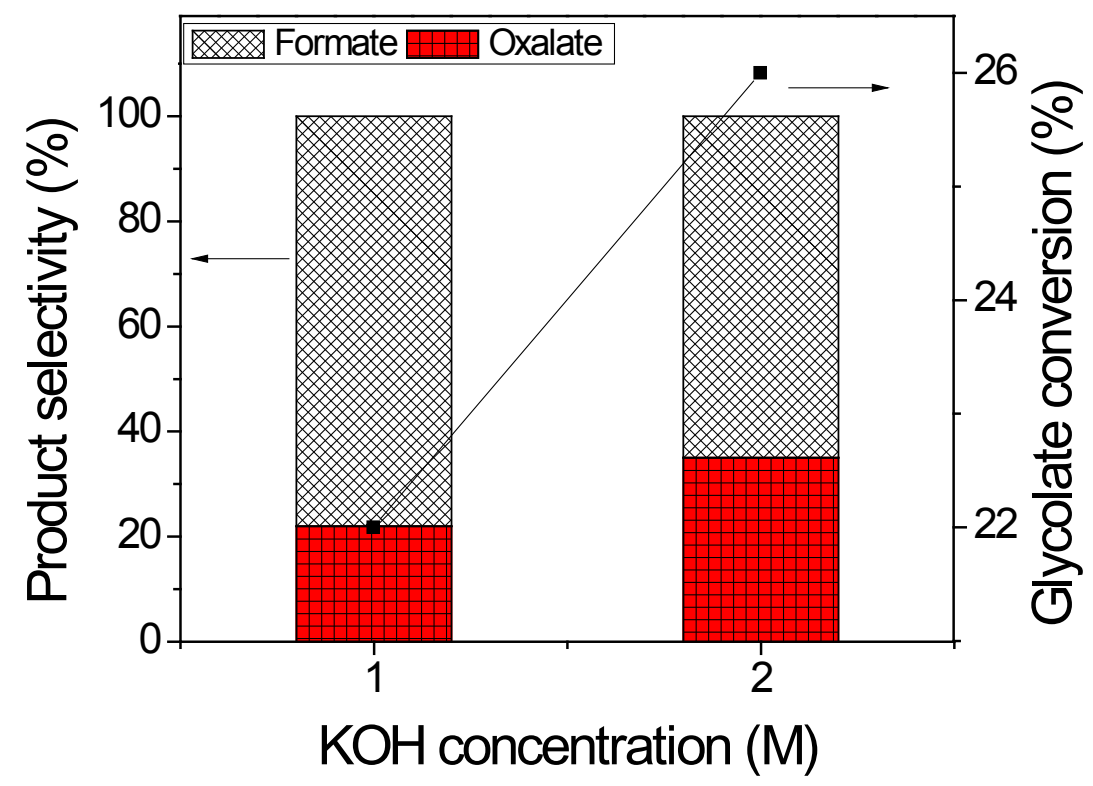

Fig. 8.8 Electro-oxidation of glycolate $(1.0 \mathrm{M})$ on $\mathrm{Au} / \mathrm{CNT}$ catalyst under different $\mathrm{KOH}$ concentrations at room temperature for 3 hours. The applied potential is $1.6 \mathrm{~V} v s$. SHE.

The concentration effects of $\mathrm{KOH}$ and glycerol were evaluated at $1.6 \mathrm{~V}$ for 3 hours, and the results are summarized in Table 8.1. It is obvious that higher concentrations of $\mathrm{KOH}$ 
would enhance the reaction rate. As the $\mathrm{KOH}$ concentration increased from $0.5 \mathrm{M}$ to 4.0 $\mathrm{M}$, the glycerol conversion jumped from $16 \%$ to $43 \%$, due to the promoted deprotonation of glycerol in higher $\mathrm{pH}$ environments. ${ }^{73,299}$ Higher $\mathrm{KOH}$ concentrations also facilitate the oxidation of hydroxyl groups in glycerol, leading to higher selectivities of tartronate and oxalate in the experiment with $4.0 \mathrm{M} \mathrm{KOH}$. Meanwhile, the initial glycerol concentration also affects the product distribution. With a lower initial glycerol concentration of $0.5 \mathrm{M}$, a larger amount of deeper-oxidized products (glycolate: $87 \%$ and oxalate: $5 \%$ ) were obtained. When the initial glycerol concentration was increased to 2.0 $\mathrm{M}$, more glycerate was observed instead. This is consistent with the observations at lower applied potentials: a lower initial glycerol concentration will favor the generation of glycolate.

Table 8.1

Electro-oxidation of glycerol on $\mathrm{Au} / \mathrm{CNT}$ at $1.6 \mathrm{~V}$ for 3 hours

\begin{tabular}{|c|c|c|c|c|c|c|c|}
\hline \multirow{2}{*}{$\begin{array}{c}\mathrm{KOH} \text { to } \\
\text { glycerol ratio }\end{array}$} & \multicolumn{5}{|c|}{ Selectivity (\%) } & \multirow{2}{*}{$\begin{array}{c}\text { Glycerol } \\
\text { conversion } \\
(\%)\end{array}$} & \multirow{2}{*}{$\begin{array}{c}\text { Carbon } \\
\text { balance } \\
(\%)\end{array}$} \\
\hline & Glycerate & Tartronate & Glyoxylate & Glycolate & Oxalate & & \\
\hline $\begin{array}{l}\text { 4.0 M KOH + } \\
1.0 \mathrm{M} \text { Glycerol }\end{array}$ & 4 & 8 & 0 & 80 & 8 & 43 & 9 \\
\hline $\begin{array}{l}2.0 \mathrm{M} \mathrm{KOH}+ \\
1.0 \mathrm{M} \text { Glycerol }\end{array}$ & 10 & 2 & 1 & 85 & 2 & 34 & 13 \\
\hline $\begin{array}{l}1.0 \mathrm{M} \mathrm{KOH}+ \\
1.0 \mathrm{M} \text { Glycerol }\end{array}$ & 14 & 2 & 1 & 81 & 2 & 26 & 19 \\
\hline $\begin{array}{l}0.5 \mathrm{M} \mathrm{KOH}+ \\
1.0 \mathrm{M} \text { Glycerol }\end{array}$ & 14 & 3 & 2 & 79 & 2 & 16 & 12 \\
\hline $\begin{array}{l}2.0 \mathrm{M} \mathrm{KOH}+ \\
2.0 \mathrm{M} \text { Glycerol }\end{array}$ & 16 & 2 & 2 & 78 & 2 & 19 & 10 \\
\hline $\begin{array}{l}2.0 \mathrm{M} \mathrm{KOH}+ \\
0.5 \mathrm{M} \text { Glycerol }\end{array}$ & 5 & 3 & 0 & 87 & 5 & 29 & 14 \\
\hline
\end{tabular}


Fig. 8.9 shows the results of $2.0 \mathrm{M} \mathrm{KOH}+1.0 \mathrm{M}$ glycerol oxidation carried out at $1.6 \mathrm{~V}$ for up to 12 hours. It is apparent that the selectivity to each product was kept almost constant during the whole reaction period, demonstrating that the reaction time has limited influences on the product distribution. This observation also indicates that the glycerol electro-oxidation product selectivity is strongly dependent on the applied potentials. The conversion of glycerol stabilized at 50\% after 6 hours reaction. However, small anodic currents were still recorded with the reaction time increasing, which may be attributed to the continuous generation of $\mathrm{C}_{1}$ products. With the reaction time increasing from 6 to 12 hours, the carbon balance gradually increased from $25 \%$ to $31 \%$. At the same time, the concentration of each observed $\mathrm{C}_{3}$ (glycerate and tartronate) and $\mathrm{C}_{2}$ products gradually decreased with the reaction time increasing, which also demonstrated the decomposition of $\mathrm{C}_{3}$ and $\mathrm{C}_{2}$ products to $\mathrm{C}_{1}$ products.

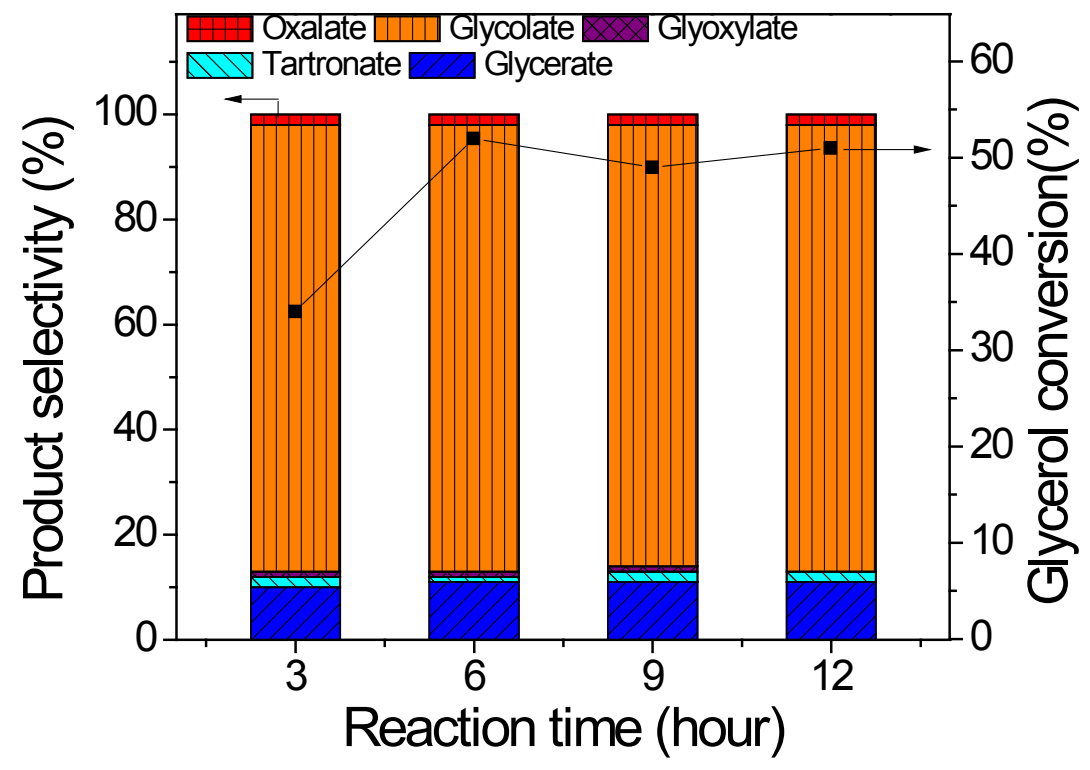

Fig. 8.9 Electro-oxidation of glycerol (2.0 M KOH $+1.0 \mathrm{M}$ glycerol) on $\mathrm{Au} / \mathrm{CNT}$ catalysts at $1.6 \mathrm{~V}$ for different reaction times. 


\subsubsection{Reaction mechanism of the electro-catalytic oxidation of glycerol}

Based on the production distributions under each applied potential, a reaction pathway was proposed for the Au-catalyzed electro-oxidation of glycerol in alkaline solution (Fig. 8.10). Glycerol is first oxidized to glycerate, which is observed from $0.35 \mathrm{~V}$ (Fig. 8.4) at $50^{\circ} \mathrm{C}$. It is noted that the selectivity to glycerate is always stable at $10-20 \%$, which is almost not affected by the applied potential, $\mathrm{KOH}$ to glycerol ratio, or reaction time. This indicates that the selectivity to glycerate in the electro-catalytic reactor is probably diffusion controlled: Glycerol first diffuses from the bulk electrolyte into the catalyst layer and is adsorbed on the surface of the Au catalyst, where one of its primary alcohol groups is oxidized to form glycerate. While some part of glycerate dissolves from the catalyst layer into the bulk electrolyte, most of it is still "trapped" in the thick catalyst layer due to the high Au loading $\left(5.0 \mathrm{mg} \mathrm{cm}^{-2}\right)$. The trapped glycerate is further quickly oxidized either to tartronate through the oxidation of the second primary alcohol group (favored at lower applied potential), or to glycolate through the $\mathrm{C}-\mathrm{C}$ bond cleavage (favored at higher applied potential). The percentage of glycerate dissolved into the bulk electrolyte is mainly controlled by the diffusion in the system. As a result, the observed glycerate selectivity in the bulk electrolyte is always stable and not affected by the applied potential, $\mathrm{KOH}$ to glycerol ratio, or the reaction time. As shown in Table 6.1, in the $\mathrm{Au}$ anode AEM-DGFC with a lower Au loading of $1.0 \mathrm{mg}_{\mathrm{Au}} \mathrm{cm}^{-2}$ (the catalyst layer is thinner), the glycerate selectivity is $17-26 \%$.

At the lower applied potentials, the trapped glycerate is then quickly oxidized to tartronate (the green arrow pathway). Due to the similar structure of the first primary alcohol group and second primary alcohol group (the one in glycerate), it is reasonable to believe the activation energies for their oxidation are close and require a similar overpotential to take place in the electro-catalytic process. Therefore, tartronate is also observed from $0.35 \mathrm{~V}$. The trapped glycerate is also oxidized to glycolate through a C-C bond breakage reaction. This step is very slow at lower applied potentials (Fig. 8.5 (a)). However, it becomes overwhelming at higher applied potentials, even at room 
temperature (Fig. 8.7). The obtained glycolate is also slowly oxidized to oxalate and formate (not listed in the reaction pathway), which is proved by Fig. 8.8. Comparing to the oxidation of glycerate to tartronate, the oxidation of the alcohol group in tartronate is more potentially sensitive, which requires a higher anode applied potential of $>0.45 \mathrm{~V}$ at $50^{\circ} \mathrm{C}$. The oxidation rate of tartronate to mesoxalate is improved when the anode applied potential is further increased, which is evidenced by the continuous increasing of the mesoxalate selectivity and the corresponding decrease in tartronate selectivity (Fig. 8.4). Mesoxalate is also slowly over-oxidized to oxalate, leading to a slight increase in the selectivity to oxalate at a longer reaction time (Fig. 8.5 (b)). At lower applied potentials, tartronate is also slowly oxidized to glyoxylate, which is then quickly oxidized to oxalate. As a result of this step, oxalate was observed before $0.4 \mathrm{~V}$ without any detection of glyoxylate. It is also important to mention that the oxidation of tartronate to glyoxylate is also enhanced at higher potentials, which is evidenced by the selectivity of $4 \%$ to glyoxylate at $1.2 \mathrm{~V}$ at room temperature.

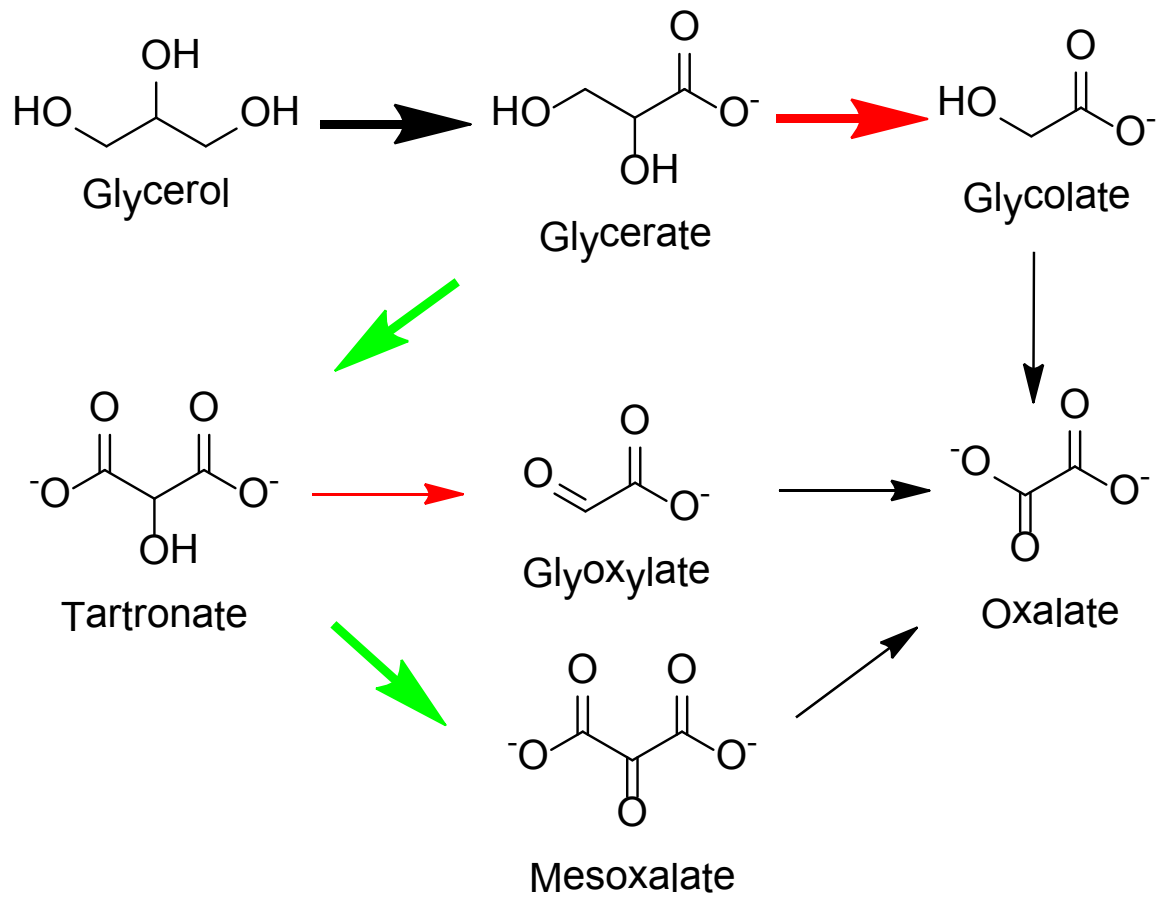

$\begin{array}{ll}\text { Bold arrow: main reactions } & \text { Green: favored at lower } \text { potentials } \\ \text { Normal arrow: minor reactions } & \text { Red: favored at higher potentials } \\ { }^{*} \mathrm{C}_{1} \text { products are not included in the scheme }\end{array}$

Fig. 8.10 Proposed reaction pathway for electro-oxidation of glycerol on Au catalyst in alkaline electrolyte. 


\subsection{Conclusion}

In this chapter, $\mathrm{Au} / \mathrm{C}$ and $\mathrm{Au} / \mathrm{CNT}$ catalysts were prepared through a solution phase synthesis method, and were successfully assembled into two electro-catalytic reactors for the accurate investigation of glycerol electro-oxidation at lower and higher applied potentials, respectively. The work clearly clarified that the product distribution is strongly controlled by the anode applied potential. At potentials $<0.4 \mathrm{~V}$, the main product is tartronate ( $78 \%$ at up to $35 \%$ glycerol conversion), with no mesoxalate detected; while at $0.65 \mathrm{~V}$, the main product was potentially switched to mesoxalate $(57 \%$ at up to $78 \%$ glycerol conversion). When the anode applied potential increased to $1.6 \mathrm{~V}$, the main product further switched to glycolate ( $85 \%$ at up to $50 \%$ glycerol conversion). Based on the results, a reaction pathway for glycerol electro-oxidation on $\mathrm{Au}$ catalysts was proposed, which can guide the selective production of a series of high value chemicals from the oxidation of biorenewable glycerol. As the electro-catalytic process takes place under mild reaction conditions $\left(<50^{\circ} \mathrm{C}\right.$, atmosphere pressure, water as the solvent), it implies a more efficient alternative green approach to the current syntheses of tartronate, mesoxalate, and glycolate. 


\section{Chapter 9 Recommendations and future work}

My Ph.D work has successfully developed a wet chemistry-based organic phase reduction route. Through the method, a series of advanced nanostructured catalysts were prepared and demonstrated high electro-catalytic activity for electricity generation and biorenewable alcohol conversion. However, there still are many improvement need to be done in the future.

In Chapter 3, 4 and 5, I prepared the Pt-Fe NWs, Pd-Fe NLs, and Pd-Ni NPs catalyst. The Pt-Fe NWs have shown high durability in acidic electrolytes towards oxygen reduction reaction; the Pd-Fe have been found as a highly active catalyst towards oxygen reduction reaction in alkaline electrolytes; Pd-Ni NPs have demonstrated as an efficient catalyst toward ethanol electro-oxidation in alkaline electrolyte. However, all of the tests were done in half cells. In the future work, the performances of these catalysts in single fuel cells are still under investigations.

In Chapter 7, I demonstrated the idea of cogenerating both electricity and valuable chemicals based on a Pt-anode AEM-DGFC. The work is just the beginning of the cogeneration project. The future work is still needed in different fuels, catalysts, and scale-up. First, other fuels besides glycerol should be considered, for example, 1,2propandiol, ethylene glycol, sorbitol, glucose, etc. to obtain different products. Second, multi-metallic catalysts should be prepared and applied as the anode, to investigate the composition effects on the product selectivity. Third, the cogeneration concept can be applied as a self-powered chemical production pilot-plant. However, in my Ph.D work, the reaction was restricted in the lab-scale. In order to scale it up, the design and fabrication of larger reactors are required. Works are also needed to address to the mass and heat transfer issues in the large scale applications.

In Chapter 8, I demonstrated the concept of electro-catalytic reactor, and demonstrated the potential regulated electro-oxidation of glycerol. This project can be extended to the 
electro-catalytic conversion of other biomass derived feedstock. The investigations of different monometallic and bimetallic catalysts are also needed. Since my finished work is focused on the oxidation reaction in the alkaline electrolytes, in the future work, the investigation of lower pHs and the reduction reaction are also of research interests. The scale-up is also a research project before the wide application of this green alternative chemical production route. 


\section{References}

1. Smalley RE. Top ten problems of humanity for next 50 years. Energy \& Nano Technology Conference. Rice University2003.

2. Central Intelligence Agency [Internet]. Washington D.C: Central Intelligence Agency. The World Factbook; 2012 [updated 2012 Jul. 10, cited 2012 Jul 23]. Available from: $\quad$ https://www.cia.gov/library/publications/the-worldfactbook/geos/xx.html.

3. Dresselhaus MS, Thomas IL. Alternative energy technologies. Nature 2001;414(6861):332-337.

4. Carrette L, Friedrich KA, Stimming U. Fuel cells - fundamentals and applications. Fuel Cells 2001;1(1):5-39.

5. Lawrence Livermore National Laboratory [Internet]. Livermore (CA): Lawrence Livermore National Laboratory. Estimated Energy Use in 2010; 2011 [cited 2012 Jul 20]. Available from:

https://flowcharts.1lnl.gov/content/energy/energy_archive/energy_flow_2010/LL NLUSEnergy2010.png.

6. Biodiesel [Internet]. Jefferson City (MO): National Biodiesel Board. Biodiesel production statistics. 2012 [cited 2012 July 21]. Available from: $<\underline{\text { http://www.biodiesel.org/production/production-statistics }>\text {. }}$

7. Gallezot P. Alternative value chains for biomass conversion to chemicals. Topics in Catalysis 2010;53(15-18):1209-1213. 
8. Bozell JJ, Petersen GR. Technology development for the production of biobased products from biorefinery carbohydrates-the US Department of Energy's "Top 10" revisited. Green Chemistry 2010;12(4):539-554.

9. Vispute TP, Zhang HY, Sanna A, Xiao R, Huber GW. Renewable chemical commodity feedstocks from integrated catalytic processing of pyrolysis oils. Science 2010;330(6008):1222-1227.

10. Zakzeski J, Bruijnincx PCA, Jongerius AL, Weckhuysen BM. The catalytic valorization of lignin for the production of renewable chemicals. Chemical Reviews 2010;110(6):3552-3599.

11. Maher KD, Bressler DC. Pyrolysis of triglyceride materials for the production of renewable fuels and chemicals. Bioresource Technology 2007;98(12):2351-2368.

12. Johnson DT, Taconi KA. The glycerin glut: Options for the value-added conversion of crude glycerol resulting from biodiesel production. Environmental Progress 2007;26(4):338-348.

13. Pagliaro M, Ciriminna R, Kimura H, Rossi M, Della Pina C. From glycerol to value-added products. Angewandte Chemie International Edition 2007;46(24):4434-4440.

14. Katryniok B, Kimura H, Skrzynska E, Girardon J-S, Fongarland P, Capron M, Ducoulombier R, Mimura N, Paul S, Dumeignil F. Selective catalytic oxidation of glycerol: perspectives for high value chemicals. Green Chemistry 2011;13(8):1960-1979. 
15. Zhou CHC, Beltramini JN, Fan YX, Lu GQM. Chemoselective catalytic conversion of glycerol as a biorenewable source to valuable commodity chemicals. Chemical Society Reviews 2008;37(3):527-549.

16. Behr A, Eilting J, Irawadi K, Leschinski J, Lindner F. Improved utilisation of renewable resources: New important derivatives of glycerol. Green Chemistry 2008;10(1):13-30.

17. Carrettin S, McMorn P, Johnston P, Griffin K, Hutchings GJ. Selective oxidation of glycerol to glyceric acid using a gold catalyst in aqueous sodium hydroxide. Chemical Communications 2002(7):696-697.

18. Porta F, Prati L. Selective oxidation of glycerol to sodium glycerate with gold-oncarbon catalyst: an insight into reaction selectivity. Journal of Catalysis 2004;224(2):397-403.

19. Gallezot P. Selective oxidation with air on metal catalysts. Catalysis Today 1997;37(4):405-418.

20. Hu WB, Knight D, Lowry B, Varma A. Selective oxidation of glycerol to dihydroxyacetone over $\mathrm{Pt}-\mathrm{Bi} / \mathrm{C}$ catalyst: optimization of catalyst and reaction conditions. Industrial \& Engineering Chemistry Research 2010;49(21):1087610882.

21. Sankar M, Dimitratos N, Knight DW, Carley AF, Tiruvalam R, Kiely CJ, Thomas D, Hutchings GJ. Oxidation of glycerol to glycolate by using supported gold and palladium nanoparticles. Chemsuschem 2009;2(12):1145-1151.

22. Markovic NM, Ross PN. Surface science studies of model fuel cell electrocatalysts. Surface Science Reports 2002;45(4-6):121-229. 
23. Markovic NM, Gasteiger HA, Ross PN. Oxygen reduction on platinum low-index single-crystal surfaces in sulfuric acid solution: Rotating ring-Pt(hkl) disk studies. The Journal of Physical Chemistry 1995;99(11):3411-3415.

24. Markovic NM, Gasteiger HA, Philip N. Oxygen reduction on platinum low-index single-crystal surfaces in alkaline solution: Rotating ring $\operatorname{disk}(\mathrm{Pt}(\mathrm{hkl}))$ studies. Journal of Physical Chemistry 1996;100(16):6715-6721.

25. Savinova ER, Kraft P, Pettinger B, Doblhofer K. In situ Raman spectroscopy studies of the interface between silver(111) electrodes and alkaline $\mathrm{NaF}$ electrolytes. Journal of Electroanalytical Chemistry 1997;430(1-2):47-56.

26. Jerkiewicz G. Hydrogen sorption at/in electrodes. Progress in Surface Science 1998;57(2):137-186.

27. Chen AC, Lipkowski J. Electrochemical and spectroscopic studies of hydroxide adsorption at the $\mathrm{Au}(111)$ electrode. Journal of Physical Chemistry B 1999;103(4):682-691.

28. Climent V, Markovic NM, Ross PN. Kinetics of oxygen reduction on an epitaxial film of palladium on $\mathrm{Pt}(111)$. Journal of Physical Chemistry B 2000;104(14):3116-3120.

29. Markovic NM, Schmidt TJ, Stamenkovic V, Ross PN. Oxygen reduction reaction on Pt and Pt bimetallic surfaces: A selective review. Fuel Cells 2001;1(2):105-116.

30. Tripkovic AV, Popovic KD, Lovic JD. The influence of the oxygen-containing species on the electrooxidation of the $\mathrm{C}_{1}-\mathrm{C}_{4}$ alcohols at some platinum single crystal surfaces in alkaline solution. Electrochimica Acta 2001;46(20-21):31633173. 
31. Schmidt TJ, Stamenkovic V, Arenz M, Markovic NM, Ross Jr PN. Oxygen electrocatalysis in alkaline electrolyte: $\mathrm{Pt}(\mathrm{hkl}), \mathrm{Au}(\mathrm{hkl})$ and the effect of Pdmodification. Electrochimica Acta 2002;47(22-23):3765-3776.

32. Gonzalez ER, Antolini E, Salgado JRC. The stability of Pt-M (M=first row transition metal) alloy catalysts and its effect on the activity in low temperature fuel cells. Journal of Power Sources 2006;160(2):957-968.

33. Yano H, Kataoka M, Yamashita H, Uchida H, Watanabe M. Oxygen reduction activity of carbon-supported $\mathrm{Pt}-\mathrm{M}(\mathrm{M}=\mathrm{V}, \mathrm{Ni}, \mathrm{Cr}, \mathrm{Co}$, and $\mathrm{Fe})$ alloys prepared by nanocapsule method. Langmuir 2007;23(11):6438-6445.

34. Wang JX, Inada H, Wu LJ, Zhu YM, Choi YM, Liu P, Zhou WP, Adzic RR. Oxygen reduction on well-defined core-shell nanocatalysts: Particle size, facet, and Pt shell thickness effects. Journal of the American Chemical Society 2009;131(47):17298-17302.

35. Jayasayee K, Veen JARV, Manivasagam TG, Celebi S, Hensen EJM, de Bruijn FA. Oxygen reduction reaction (ORR) activity and durability of carbon supported PtM (Co, Ni, Cu) alloys: Influence of particle size and non-noble metals. Applied Catalysis B: Environmental 2012;111-112:515-526.

36. Zhou WJ, Zhou ZH, Song SQ, Li WZ, Sun GQ, Tsiakaras P, Xin Q. Pt based anode catalysts for direct ethanol fuel cells. Applied Catalysis B: Environmental 2003;46(2):273-285.

37. Zhou WJ, Li WZ, Song SQ, Zhou ZH, Jiang LH, Sun GQ, Xin Q, Poulianitis K, Kontou S, Tsiakaras P. Bi- and tri-metallic Pt-based anode catalysts for direct ethanol fuel cells. Journal of Power Sources 2004;131(1-2):217-223. 
38. Kowal A, Li M, Shao M, Sasaki K, Vukmirovic MB, Zhang J, Marinkovic NS, Liu P, Frenkel AI, Adzic RR. Ternary Pt/Rh/SnO2 electrocatalysts for oxidizing ethanol to CO2. Nature Materials 2009;8(4):325-330.

39. Kang YJ, Qi L, Li M, Diaz RE, Su D, Adzic RR, Stach E, Li J, Murray CB. Highly active $\mathrm{Pt}_{3} \mathrm{~Pb}$ and core-shell $\mathrm{Pt}_{3} \mathrm{~Pb}-\mathrm{Pt}$ electrocatalysts for formic acid oxidation. Acs Nano 2012;6(3):2818-2825.

40. Lee HJ, Habas SE, Somorjai GA, Yang PD. Localized Pd overgrowth on cubic Pt nanocrystals for enhanced electrocatalytic oxidation of formic acid. Journal of the American Chemical Society 2008;130(16):5406-5407.

41. Chen W, Kim J, Sun SH, Chen SW. Electro-oxidation of formic acid catalyzed by FePt nanoparticles. Physical Chemistry Chemical Physics 2006;8(23):2779-2786.

42. Choi JH, Jeong KJ, Dong Y, Han J, Lim TH, Lee JS, Sung YE. Electro-oxidation of methanol and formic acid on PtRu and PtAu for direct liquid fuel cells. Journal of Power Sources 2006;163(1):71-75.

43. Chen W, Kim JM, Sun SH, Chen SW. Composition effects of FePt alloy nanoparticles on the electro-oxidation of formic acid. Langmuir 2007;23(22):11303-11310.

44. Winjobi O, Zhang ZY, Liang CH, Li WZ. Carbon nanotube supported platinumpalladium nanoparticles for formic acid oxidation. Electrochimica Acta 2010;55(13):4217-4221.

45. Ozin GA. Nanochemistry: Synthesis in diminishing dimensions. Advanced Materials 1992;4(10):612-649. 
46. Zhang S, Shao Y, Yin G, Lin Y. Electrostatic self-assembly of a Pt-around-Au nanocomposite with high activity towards formic acid oxidation. Angewandte Chemie International Edition 2010;49(12):2211-2214.

47. Wang SY, Wang X, Jiang SP. Controllable self-assembly of Pd nanowire networks as highly active electrocatalysts for direct formic acid fuel cells. Nanotechnology 2008;19(45): 455602.

48. Martin CR. Nanomaterials - a membrane-based synthetic approach. Science 1994;266(5193):1961-1966.

49. C. Hulteen J, Martin CR. A general template-based method for the preparation of nanomaterials. Journal of Materials Chemistry 1997;7(7):1075-1087.

50. Marković NM, Schmidt TJ, Grgur BN, Gasteiger HA, Behm RJ, Ross PN. Effect of temperature on surface processes at the $\operatorname{Pt}(111)$-liquid interface: hydrogen adsorption, oxide Formation, and $\mathrm{CO}$ oxidation. The Journal of Physical Chemistry B 1999;103(40):8568-8577.

51. Dong S, Zhou S. Photochemical synthesis of colloidal gold nanoparticles. Materials Science and Engineering: B 2007;140(3):153-159.

52. Dong S, Tang C, Zhou H, Zhao H. Photochemical synthesis of gold nanoparticles by the sunlight radiation using a seeding approach. Gold Bulletin 2004;37(3):187195.

53. Suslick KS, Fang M, Hyeon T. Sonochemical synthesis of iron colloids. Journal of the American Chemical Society 1996;118(47):11960-11961.

54. Treguer M, de Cointet C, Remita H, Khatouri J, Mostafavi M, Amblard J, Belloni J, de Keyzer R. Dose rate effects on radiolytic synthesis of gold-silver bimetallic 
clusters in solution. The Journal of Physical Chemistry B 1998;102(22):43104321.

55. Bron M, Bogdanoff $\mathrm{P}$, Fiechter S, Hilgendorff M, Radnik J, Dorbandt I, Schulenburg H, Tributsch H. Carbon supported catalysts for oxygen reduction in acidic media prepared by thermolysis of $\mathrm{Ru}_{3}(\mathrm{CO})_{12}$. Journal of Electroanalytical Chemistry 2001;517(1-2):85-94.

56. Xia Y, Xiong Y, Lim B, Skrabalak SE. Shape-controlled synthesis of metal nanocrystals: simple chemistry meets complex physics? Angewandte Chemie International Edition 2009;48(1):60-103.

57. Zhou H, Zhou W, Adzic RR, Wong SS. Enhanced electrocatalytic performance of one-dimensional metal nanowires and arrays generated via an ambient, surfactantless synthesis. Journal of Physical Chemistry C 2009:5460-5466.

58. Huang XQ, Zheng NF. One-pot, high-yield synthesis of 5-Fold twinned Pd nanowires and nanorods. Journal of the American Chemical Society 2009;131(13):4602-4603.

59. Xiong YJ, Cai HG, Wiley BJ, Wang JG, Kim MJ, Xia YN. Synthesis and mechanistic study of palladium nanobars and nanorods. Journal of the American Chemical Society 2007;129(12):3665-3675.

60. Xu D, Liu Z, Yang H, Liu Q, Zhang J, Fang J, Zou S, Sun K. Solution-based evolution and enhanced methanol oxidation activity of monodisperse PlatinumCopper nanocubes. Angewandte Chemie International Edition 2009;121(23):4281-4285. 
61. Han S, Song Y, Lee J, Kim J, Park K. Platinum nanocube catalysts for methanol and ethanol electrooxidation. Electrochemistry Communications 2008;10(7):1044-1047.

62. Huang L, Wang M, Zhang Y, Guo Z, Sun J, Gu N. Synthesis of gold nanotadpoles by a temperature-reducing seed approach and the dielectrophoretic manipulation. The Journal of Physical Chemistry C 2007;111(44):16154-16160.

63. Lim B, Jiang MJ, Camargo PHC, Cho EC, Tao J, Lu XM, Zhu YM, Xia YA. PdPt bimetallic nanodendrites with high activity for oxygen reduction. Science 2009;324(5932):1302-1305.

64. Guo SJ, Dong SJ, Wang EW. Three-dimensional Pt-on-Pd bimetallic nanodendrites supported on graphene nanosheet: facile synthesis and used as an advanced nanoelectrocatalyst for methanol oxidation. Acs Nano 2010;4(1):547555.

65. Hao R, Xing RJ, Xu ZC, Hou YL, Gao S, Sun SH. Synthesis, functionalization, and biomedical applications of multifunctional magnetic nanoparticles. Advanced Materials 2010;22(25):2729-2742.

66. Wang C, Sun SH. Facile synthesis of ultrathin and single-crystalline Au nanowires. Chemistry-an Asian Journal 2009;4(7):1028-1034.

67. Sun SH. Recent advances in chemical synthesis, self-assembly, and applications of FePt nanoparticles. Advanced Materials 2006;18(4):393-403.

68. Xia YN, Yang PD, Sun YG, Wu YY, Mayers B, Gates B, Yin YD, Kim F, Yan YQ. One-dimensional nanostructures: Synthesis, characterization, and applications. Advanced Materials 2003;15(5):353-389. 
69. Tao AR, Habas S, Yang PD. Shape control of colloidal metal nanocrystals. Small $2008 ; 4(3): 310-325$.

70. Bard AJ, Faulkner LR. Electrochemical methods: fundamentals and applications. $2^{\text {nd }}$ ed. New York (NY): Wiley; 2001.

71. Elezovic NR, Babic BM, Vracar LJM, Krstajic NV. Oxygen reduction at platinum nanoparticles supported on carbon cryogel in alkaline solution. Journal of the Serbian Chemical Society 2007;72(7):699-708.

72. Kwon Y, Koper MTM. Combining voltammetry with HPLC: application to electro-oxidation of glycerol. Analytical Chemistry 2010;82(13):5420-5424.

73. Koper MTM, Kwon Y, Lai SCS, Rodriguez P. Electrocatalytic oxidation of alcohols on gold in alkaline media: Base or gold catalysis? Journal of the American Chemical Society 2011;133(18):6914-6917.

74. Kwon Y, Schouten KJP, Koper MTM. Mechanism of the catalytic oxidation of glycerol on polycrystalline gold and platinum electrodes. Chemcatchem 2011;3(7):1176-1185.

75. Ketchie WC, Murayama M, Davis RJ. Promotional effect of hydroxyl on the aqueous phase oxidation of carbon monoxide and glycerol over supported $\mathrm{Au}$ catalysts. Topics in Catalysis 2007;44(1-2):307-317.

76. Zope BN, Hibbitts DD, Neurock M, Davis RJ. Reactivity of the gold/water interface during selective oxidation catalysis. Science 2010;330(6000):74-78.

77. Wroblowa HS, Yen Chi P, Razumney G. Electroreduction of oxygen: A new mechanistic criterion. Journal of Electroanalytical Chemistry and Interfacial Electrochemistry 1976;69(2):195-201. 
78. Norskov JK, Rossmeisl J, Logadottir A, Lindqvist L, Kitchin JR, Bligaard T, Jonsson H. Origin of the overpotential for oxygen reduction at a fuel-cell cathode. Journal of Physical Chemistry B 2004;108(46):17886-17892.

79. Savadogo O, Lee K, Oishi K, Mitsushima S, Kamiya N, Ota KI. New palladium alloys catalyst for the oxygen reduction reaction in an acid medium. Electrochemistry Communications 2004;6(2):105-109.

80. Fernandez JL, Raghuveer V, Manthiram A, Bard AJ. Pd-Ti and Pd-Co-Au electrocatalysts as a replacement for platinum for oxygen reduction in proton exchange membrane fuel cells. Journal of the American Chemical Society 2005;127(38):13100-13101.

81. Sarkar A, Murugan AV, Manthiram A. Synthesis and characterization of nanostructured Pd-Mo electrocatalysts for oxygen reduction reaction in fuel cells. Journal of Physical Chemistry C 2008;112(31):12037-12043.

82. Ang S-Y, Walsh DA. Palladium-vanadium alloy electrocatalysts for oxygen reduction: Effect of heat treatment on electrocatalytic activity and stability. Applied Catalysis B: Environmental 2010;98(1-2):49-56.

83. Adzic RR. Recent advances in the kinetics of oxygen reduction reaction. In: Lipkowski J, Ross PN, editors. Electrocatalysis. New York (NY): Wiley-VCH; 1998.

84. Borup R, Meyers J, Pivovar B, Kim YS, Mukundan R, Garland N, Myers D, Wilson M, Garzon F, Wood D and others. Scientific aspects of polymer electrolyte fuel cell durability and degradation. Chemical Reviews 2007;107(10):3904-3951. 
85. Jian X, Wood DL, More KL, Atanassov P, Borup RL. Microstructural changes of membrane electrode assemblies during PEFC durability testing at high humidity conditions. Journal of the Electrochemical Society 2005;152(5):A1011-20.

86. Ferreira PJ, la O GJ, Shao-Horn Y, Morgan D, Makharia R, Kocha S, Gasteiger HA. Instability of Pt/C electrocatalysts in proton exchange membrane fuel cells A mechanistic investigation. Journal of the Electrochemical Society 2005;152(11):A2256-A2271.

87. Shao-Horn Y, Sheng WC, Chen S, Ferreira PJ, Holby EF, Morgan D. Instability of supported platinum nanoparticles in low-temperature fuel cells. Topics in Catalysis 2007;46(3-4):285-305.

88. Zhang J, Sasaki K, Sutter E, Adzic RR. Stabilization of platinum oxygenreduction electrocatalysts using gold clusters. Science 2007;315(5809):220-222.

89. Chen ZW, Waje M, Li WZ, Yan YS. Supportless Pt and PtPd nanotubes as electrocatalysts for oxygen-reduction reactions. Angewandte Chemie International Edition 2007;46(22):4060-4063.

90. Tan Y, Fan J, Chen G, Zheng N, Xie Q. Au/Pt and Au/Pt3Ni nanowires as selfsupported electrocatalysts with high activity and durability for oxygen reduction. Chemical Communications 2011;47(42):11624-11626.

91. Yano H, Akiyama T, Bele P, Uchida H, Watanabe M. Durability of Pt/graphitized carbon catalysts for the oxygen reduction reaction prepared by the nanocapsule method. Physical Chemistry Chemical Physics 2010;12(15):3806-3814.

92. Zhang ZY, Li MJ, Wu ZL, Li WZ. Ultra-thin PtFe-nanowires as durable electrocatalysts for fuel cells. Nanotechnology 2011;22(1): 015602. 
93. Li WZ, Haldar P. Supportless PdFe nanorods as highly active electrocatalyst for proton exchange membrane fuel cell. Electrochemistry Communications 2009;11(6):1195-1198.

94. Wang C, Hou YL, Kim JM, Sun SH. A general strategy for synthesizing FePt nanowires and nanorods. Angewandte Chemie International Edition 2007;46(33):6333-6335.

95. Li WZ, Xin Q, Yan YS. Nanostructured Pt-Fe/C cathode catalysts for direct methanol fuel cell: The effect of catalyst composition. International Journal of Hydrogen Energy 2010;35(6):2530-2538.

96. Paulus UA, Wokaun A, Scherer GG, Schmidt TJ, Stamenkovic V, Radmilovic V, Markovic NM, Ross PN. Oxygen reduction on carbon-supported Pt-Ni and Pt-Co alloy catalysts. Journal of Physical Chemistry B 2002;106(16):4181-4191.

97. Sun SH, Fullerton EE, Weller D, Murray CB. Compositionally controlled FePt nanoparticle materials. Ieee Transactions on Magnetics 2001;37(4):1239-1243.

98. Li WZ, Liang CH, Qiu JS, Li HQ, Zhou WJ, Sun GQ, Xin Q. Multi-walled carbon nanotubes supported Pt-Fe cathodic catalyst for direct methanol fuel cell. Reaction Kinetics and Catalysis Letters 2004;82(2):235-240.

99. Li WZ, Zhou WJ, Li HQ, Zhou ZH, Zhou B, Sun GQ, Xin Q. Nano-stuctured Pt$\mathrm{Fe} / \mathrm{C}$ as cathode catalyst in direct methanol fuel cell. Electrochimica Acta 2004;49(7):1045-1055.

100. Li WZ, Liang CH, Zhou WJ, Qiu JS, Zhou ZH, Sun GQ, Xin Q. Preparation and characterization of multiwalled carbon nanotube-supported platinum for cathode 
catalysts of direct methanol fuel cells. Journal of Physical Chemistry B 2003;107(26):6292-6299.

101. Li WZ, Liang CH, Qiu JS, Zhou WJ, Han HM, Wei ZB, Sun GQ, Xin Q. Carbon nanotubes as support for cathode catalyst of a direct methanol fuel cell. Carbon 2002;40(5):791-794.

102. Burkert T, Eriksson O, Simak SI, Ruban AV, Sanyal B, Nordström L, Wills JM. Magnetic anisotropy of $\mathrm{L}_{0} \quad \mathrm{FePt}$ and $\mathrm{Fe}_{1-\mathrm{x}} \mathrm{Mn}_{\mathrm{x}} \mathrm{Pt}$. Physical Review $\mathrm{B}$ 2005;71(13):134411.

103. Brown G, Kraczek B, Janotti A, Schulthess TC, Stocks GM, Johnson DD. Competition between ferromagnetism and antiferromagnetism in FePt. Physical Review B 2003;68(5):052405.

104. Toda T, Igarashi H, Uchida H, Watanabe M. Enhancement of the electroreduction of oxygen on Pt alloys with $\mathrm{Fe}, \mathrm{Ni}$, and Co. Journal of the Electrochemical Society 1999;146(10):3750-3756.

105. Gasteiger HA, Kocha SS, Sompalli B, Wagner FT. Activity benchmarks and requirements for Pt, Pt-alloy, and non-Pt oxygen reduction catalysts for PEMFCs. Applied Catalysis B: Environmental 2005;56(1-2):9-35.

106. Stamenkovic VR, Fowler B, Mun BS, Wang GF, Ross PN, Lucas CA, Markovic NM. Improved oxygen reduction activity on $\mathrm{Pt}_{3} \mathrm{Ni}(111)$ via increased surface site availability. Science 2007;315(5811):493-497.

107. Li WZ, Haldar P. Highly active carbon supported core-shell PtNi@Pt Nanoparticles for oxygen reduction reaction. Electrochemical and Solid State Letters 2010;13(5):B47-B49. 
108. Vielstich W, Lamm A, Gasteiger HA. Handbook of Fuel Cells: Fundamentals, Technology, Applications. New York: Wiley; 2003.

109. Varcoe JR, Slade RCT. Prospects for alkaline anion-exchange membranes in low temperature fuel cells. Fuel Cells 2005;5(2):187-200.

110. Agel E, Bouet J, Fauvarque JF. Characterization and use of anionic membranes for alkaline fuel cells. Journal of Power Sources 2001;101(2):267-274.

111. Lu SF, Pan J, Huang AB, Zhuang L, Lu JT. Alkaline polymer electrolyte fuel cells completely free from noble metal catalysts. Proceedings of the National Academy of Sciences of the United States of America 2008;105(52):20611-20614.

112. Gu S, Cai R, Luo T, Chen Z, Sun M, Liu Y, He G, Yan Y. A soluble and highly conductive ionomer for high-performance hydroxide exchange membrane fuel cells. Angewandte Chemie International Edition 2009;48(35):6499-6502.

113. Gu S, Cai R, Luo T, Jensen K, Contreras C, Yan YS. Quaternary phosphoniumbased polymers as hydroxide exchange membranes. Chemsuschem 2010;3(5):555-558.

114. Yu EH, Krewer U, Scott K. Principles and materials aspects of direct alkaline alcohol fuel cells. Energies 2010;3(8):1499-1528.

115. Spendelow JS, Wieckowski A. Electrocatalysis of oxygen reduction and small alcohol oxidation in alkaline media. Physical Chemistry Chemical Physics 2007;9(21):2654-2675.

116. Christensen PA, Hamnett A, Linares-Moya D. Oxygen reduction and fuel oxidation in alkaline solution. Physical Chemistry Chemical Physics 2011;13(12):5206-5214. 
117. Antolini E, Gonzalez ER. Alkaline direct alcohol fuel cells. Journal of Power Sources 2010;195(11):3431-3450.

118. Meadowcroft DB. Low-cost oxygen electrode material. Nature 1970;226:2.

119. Lima FHB, Zhang J, Shao MH, Sasaki K, Vukmirovic MB, Ticianelli EA, Adzic RR. Catalytic activity-d-band center correlation for the $\mathrm{O}_{2}$ reduction reaction on platinum in alkaline solutions. Journal of Physical Chemistry C 2007;111(1):404410.

120. Li B, Prakash J. Oxygen reduction reaction on carbon supported palladium-nickel alloys in alkaline media. Electrochemistry Communications 2009;11(6):11621165.

121. Jiang L, Hsu A, Chu D, Chen R. Size-dependent Activity of palladium nanoparticles for oxygen electroreduction in alkaline solutions. Journal of the Electrochemical Society 2009;156(5):B643-B649.

122. Jiang L, Hsu A, Chu D, Chen R. Oxygen reduction reaction on carbon supported Pt and Pd in alkaline solutions. Journal of the Electrochemical Society 2009;156(3):B370-B376.

123. Sepa DB, Vojnovic MV, Vracar LM, Damjanovic A. Different views regarding the kinetics and mechanisms of oxygen reduction at $\mathrm{Pt}$ and $\mathrm{Pd}$ electrodes. Electrochimica Acta 1987;32(1):129-134.

124. Seo MH, Choi SM, Kim HJ, Kim WB. The graphene-supported Pd and Pt catalysts for highly active oxygen reduction reaction in an alkaline condition. Electrochemistry Communications 2011;13(2):182-185. 
125. Sun W, Hsu A, Chen R. Palladium-coated manganese dioxide catalysts for oxygen reduction reaction in alkaline media. Journal of Power Sources 2011;196(10):4491-4498.

126. Vogel WM. The reduction of oxygen on rhodium and nickel in concentrated potassium hydroxide. Electrochimica Acta 1968;13(8):1821-1826.

127. Anastasijević N, Dimitrijević ZM, Adžić RR. Oxygen reduction on a modified ruthenium electrode. Electrochimica Acta 1992;37(3):457-464.

128. Neergat M, Gunasekar V, Rahul R. Carbon-supported Pd-Fe electrocatalysts for oxygen reduction reaction (ORR) and their methanol tolerance. Journal of Electroanalytical Chemistry 2011;658(1-2):25-32.

129. Tang Y, Cao S, Chen Y, Lu T, Zhou Y, Lu L, Bao J. Effect of Fe state on electrocatalytic activity of $\mathrm{Pd}-\mathrm{Fe} / \mathrm{C}$ catalyst for oxygen reduction. Applied Surface Science 2010;256(13):4196-4200.

130. Lee C-L, Huang Y-C, Kuo L-C, Oung J-C, Wu F-C. Preparation and characterization of $\mathrm{Pd} / \mathrm{Ag}$ and $\mathrm{Pd} / \mathrm{Ag} / \mathrm{Au}$ nanosponges with network nanowires and their high electroactivities toward oxygen reduction. Nanotechnology 2006;17(9):2390-2395.

131. Nagaiah TC, Maljusch A, Chen XX, Bron M, Schuhmann W. Visualization of the local catalytic activity of electrodeposited Pt-Ag catalysts for oxygen reduction by means of SECM. Chemphyschem 2009;10(15):2711-2718.

132. Lee C-L, Chiou H-P, Chang K-C, Huang C-H. Carbon nanotubes-supported colloidal $\mathrm{Ag}-\mathrm{Pd}$ nanoparticles as electrocatalysts toward oxygen reduction 
reaction in alkaline electrolyte. International Journal of Hydrogen Energy 2011;36(4):2759-2764.

133. Jiang L, Hsu A, Chu D, Chen R. A highly active Pd coated Ag electrocatalyst for oxygen reduction reactions in alkaline media. Electrochimica Acta 2010;55(15):4506-4511.

134. Zhang X-G, Hu F-P, Xiao F, Zhang J-L. Oxygen reduction on $\mathrm{Ag}-\mathrm{MnO}_{2} / \mathrm{SWNT}$ and $\mathrm{Ag}-\mathrm{MnO}_{2} / \mathrm{AB}$ electrodes. Carbon 2005;43(14):2931-2936.

135. Blizanac BB, Ross PN, Markovic NM. Oxygen reduction on silver low-index single-crystal surfaces in alkaline solution: Rotating ring $\operatorname{disk}(\operatorname{Ag}(\mathrm{hkl}))$ studies. Journal of Physical Chemistry B 2006;110(10):4735-4741.

136. Guo J, Hsu A, Chu D, Chen R. Improving oxygen reduction reaction activities on carbon-supported Ag nanoparticles in alkaline solutions. The Journal of Physical Chemistry C 2010;114(10):4324-4330.

137. Kuai L, Geng B, Wang S, Zhao Y, Luo Y, Jiang H. Silver and gold icosahedra: one-pot water-based synthesis and their superior performance in the electrocatalysis for oxygen reduction reactions in alkaline media. Chemistry - A European Journal 2011;17(12):3482-3489.

138. Dong G, Huang M, Guan L. Iron phthalocyanine coated on single-walled carbon nanotubes composite for the oxygen reduction reaction in alkaline media. Physical Chemistry Chemical Physics 2012;14(8):2557-2559.

139. Wu J, Zhang D, Wang Y, Wan Y, Hou B. Catalytic activity of graphene-cobalt hydroxide composite for oxygen reduction reaction in alkaline media. Journal of Power Sources 2012;198:122-126. 
140. Guo J, Li H, He H, Chu D, Chen R. CoPc- and CoPcF16-modified Ag nanoparticles as novel catalysts with tunable oxygen reduction activity in alkaline media. The Journal of Physical Chemistry C 2011;115(17):8494-8502.

141. He Q, Yang X, Ren X, Koel BE, Ramaswamy N, Mukerjee S, Kostecki R. A novel $\mathrm{CuFe}$-based catalyst for the oxygen reduction reaction in alkaline media. Journal of Power Sources 2011;196(18):7404-7410.

142. Li X, Popov BN, Kawahara T, Yanagi H. Non-precious metal catalysts synthesized from precursors of carbon, nitrogen, and transition metal for oxygen reduction in alkaline fuel cells. Journal of Power Sources 2011;196(4):1717-1722.

143. Gong K, Du F, Xia Z, Durstock M, Dai L. Nitrogen-doped carbon nanotube arrays with high electrocatalytic activity for oxygen reduction. Science 2009;323(5915):760-764.

144. Li H, Liu H, Jong Z, Qu W, Geng D, Sun X, Wang H. Nitrogen-doped carbon nanotubes with high activity for oxygen reduction in alkaline media. International Journal of Hydrogen Energy 2011;36(3):2258-2265.

145. Mo Z, Liao S, Zheng Y, Fu Z. Preparation of nitrogen-doped carbon nanotube arrays and their catalysis towards cathodic oxygen reduction in acidic and alkaline media. Carbon 2012;50(7):2620-2627.

146. Morozan A, Jégou P, Pinault M, Campidelli S, Jousselme B, Palacin S. Metal-free nitrogen-containing carbon nanotubes prepared from triazole and tetrazole derivatives show high electrocatalytic activity towards the oxygen reduction reaction in alkaline media. Chemsuschem 2012;5(4):647-651. 
147. Zhou X, Yang Z, Nie H, Yao Z, Zhang L, Huang S. Catalyst-free growth of large scale nitrogen-doped carbon spheres as efficient electrocatalysts for oxygen reduction in alkaline medium. Journal of Power Sources 2011;196(23):9970-9974.

148. Nagaiah TC, Bordoloi A, Sánchez MD, Muhler M, Schuhmann W. Mesoporous nitrogen-rich carbon materials as catalysts for the oxygen reduction reaction in alkaline solution. Chemsuschem 2012;5(4):637-641.

149. Qu L, Liu Y, Baek J-B, Dai L. Nitrogen-doped graphene as efficient metal-free electrocatalyst for oxygen reduction in fuel cells. Acs Nano 2010;4(3):1321-1326.

150. Yao Z, Nie H, Yang Z, Zhou X, Liu Z, Huang S. Catalyst-free synthesis of iodine-doped graphene via a facile thermal annealing process and its use for electrocatalytic oxygen reduction in an alkaline medium. Chemical Communications 2012;48(7):1027-1029.

151. Resources for electrochemistry [Internet]. Fernandina Beach (FL): Research Solution \& Resources LLC. Potentials of Common Reference Electrodes; 2012 [updated 2012 Apr 20, cited 2012 Jul 21]. Available from: http://www.consultrsr.com/resources/ref/refpotls.htm.

152. Mazumder V, Sun SH. Oleylamine-mediated synthesis of Pd nanoparticles for catalytic formic acid oxidation. Journal of the American Chemical Society 2009;131(13):4588-4589.

153. Chen M, Kim J, Liu JP, Fan HY, Sun SH. Synthesis of FePt nanocubes and their oriented self-assembly. Journal of the American Chemical Society 2006;128(22):7132-7133. 
154. Lim B, Jiang MJ, Tao J, Camargo PHC, Zhu YM, Xia YN. Shape-controlled synthesis of Pd nanocrystals in aqueous solutions. Advanced Functional Materials 2009;19(2):189-200.

155. Xiong YJ, Xia YN. Shape-controlled synthesis of metal nanostructures: The case of palladium. Advanced Materials 2007;19(20):3385-3391.

156. Peng $\mathrm{ZM}, \mathrm{Wu} \mathrm{JB}$, Yang $\mathrm{H}$. Synthesis and oxygen reduction electrocatalytic property of platinum hollow and platinum-on-silver nanoparticles. Chemistry of Materials 2010;22(3):1098-1106.

157. Groppi G, Cristiani C, Lietti L, Ramella C, Valentini M, Forzatti P. Effect of ceria on palladium supported catalysts for high temperature combustion of $\mathrm{CH}_{4}$ under lean conditions. Catalysis Today 1999;50(2):399-412.

158. Nguyen ST, Law HM, Nguyen HT, Kristian N, Wang SY, Chan SH, Wang X. Enhancement effect of $\mathrm{Ag}$ for $\mathrm{Pd} / \mathrm{C}$ towards the ethanol electro-oxidation in alkaline media. Applied Catalysis B: Environmental 2009;91(1-2):507-515.

159. Basic research needs for the hydrogen economy. U.S. Department of Energy, Office of Basic Science; 2004.

160. Farrell AE, Plevin RJ, Turner BT, Jones AD, O'Hare M, Kammen DM. Ethanol can contribute to energy and environmental goals. Science 2006;311(5760):506508.

161. Breaking the Biological Barriers to Cellulosic Ethanol: A Joint Research Agenda A Research Roadmap Resulting from the Biomass to Biofuels Workshop Sponsored by the US DOE, December 7-9, Rockville, Maryland (2005). 
162. Breaking the chemical and engineering barriers to lignocellulosic biofuels: next generation hydrocarbon biorefineries, A Joint Research Agenda: A Research Roadmap for making lignocellulosic biofuels a practical reality, Workshop Sponsored by the NSF, ACS and US DOE, June 25-26, Washington, D.C. (2007).

163. Growth Energy Market Development [Internet].Trackside Marketing Group. LLC. [cited 2012 Jul 21]. Available from:http://www.e85refueling.com/index.php.

164. Lamy C, Belgsir EM, Leger JM. Electrocatalytic oxidation of aliphatic alcohols: Application to the direct alcohol fuel cell (DAFC). Journal of Applied Electrochemistry 2001;31(7):799-809.

165. Zhao XS, Li WZ, Jiang LH, Zhou WJ, Xin Q, Yi BL, Sun GQ. Multi-wall carbon nanotube supported Pt-Sn nanoparticles as an anode catalyst for the direct ethanol fuel cell. Carbon 2004;42(15):3263-3265.

166. Lamy C, Rousseau S, Belgsir EM, Coutanceau C, Leger JM. Recent progress in the direct ethanol fuel cell: development of new platinum-tin electrocatalysts. Electrochimica Acta 2004;49(22-23):3901-3908.

167. Antolini E. Catalysts for direct ethanol fuel cells. Journal of Power Sources 2007;170(1):1-12.

168. Wang Q, Sun GQ, Jiang LH, Xin Q, Sun SG, Jiang YX, Chen SP, Jusys Z, Behm RJ. Adsorption and oxidation of ethanol on colloid-based $\mathrm{Pt} / \mathrm{C}, \mathrm{PtRu} / \mathrm{C}$ and Pt3Sn/C catalysts: In situ FTIR spectroscopy and on-line DEMS studies. Physical Chemistry Chemical Physics 2007;9(21):2686-2696.

169. Lamy C, Coutanceau C, Leger J-M. The Direct Ethanol Fuel Cell: a Challenge to Convert Bioethanol Cleanly into Electric Energy. In: Barbaro P, Bianchini C, 
editors. Catalysis for Sustainable Energy Production. Germany: Wiley-VCH Verlag GmbH \& Co. KGaA; 2009. p 3-46.

170. Yeager E. Electrocatalysts for $\mathrm{O}_{2}$ reduction. Electrochimica Acta 1984;29(11):1527-1537.

171. Yu EH, Scott K. Development of direct methanol alkaline fuel cells using anion exchange membranes. Journal of Power Sources 2004;137(2):248-256.

172. Matsuoka K, Iriyama Y, Abe T, Matsuoka M, Ogumi Z. Electro-oxidation of methanol and ethylene glycol on platinum in alkaline solution: Poisoning effects and product analysis. Electrochimica Acta 2005;51(6):1085-1090.

173. Varcoe JR, Slade RCT, Lam How Yee E. An alkaline polymer electrochemical interface: a breakthrough in application of alkaline anion-exchange membranes in fuel cells. Chemical Communications 2006(13):1428-1429.

174. Park JS, Park SH, Yim SD, Yoon YG, Lee WY, Kim CS. Performance of solid alkaline fuel cells employing anion-exchange membranes. Journal of Power Sources 2008;178(2):620-626.

175. Antolini E, Gonzalez ER. A simple model to assess the contribution of alloyed and non-alloyed platinum and tin to the ethanol oxidation reaction on $\mathrm{Pt}-\mathrm{Sn} / \mathrm{C}$ catalysts: Application to direct ethanol fuel cell performance. Electrochimica Acta 2010;55(22):6485-6490.

176. Li YS, Zhao TS, Liang ZX. Effect of polymer binders in anode catalyst layer on performance of alkaline direct ethanol fuel cells. Journal of Power Sources 2009;190(2):223-229. 
177. Nam J-H, Jang Y-Y, Kwon Y-U, Nam J-D. Direct methanol fuel cell Pt-carbon catalysts by using SBA-15 nanoporous templates. Electrochemistry Communications 2004;6(7):737-741.

178. $\mathrm{Xu} \mathrm{CW}$, Shen PK. Electrochemical oxidation of ethanol on $\mathrm{Pt}-\mathrm{CeO}_{2} / \mathrm{C}$ catalysts. Journal of Power Sources 2005;142(1-2):27-29.

179. Cui GF, Song SQ, Shen PK, Kowal A, Bianchini C. First-Principles Considerations on Catalytic Activity of Pd toward Ethanol Oxidation. Journal of Physical Chemistry C 2009;113(35):15639-15642.

180. Jin G, Ding Y, Zheng P. Electrodeposition of nickel nanoparticles on functional MWCNT surfaces for ethanol oxidation. Journal of Power Sources 2007;166(1):80-86.

181. Xu C, Hu Y, Rong J, Jiang S, Liu Y. Ni hollow spheres as catalysts for methanol and ethanol electrooxidation. Electrochemistry Communications 2007;9(8):20092012.

182. Zhou Z-Y, Wang Q, Lin J-L, Tian N, Sun S-G. In situ FTIR spectroscopic studies of electrooxidation of ethanol on Pd electrode in alkaline media. Electrochimica Acta 2010;55(27):7995-7999.

183. Bambagioni V, Bianchini C, Filippi J, OberhauserIal W, Marchionni A, Vizza F, Psaro R, Sordelli L, Foresti ML, Innocenti M. Ethanol oxidation on electrocatalysts obtained by spontaneous deposition of palladium onto nickel-zinc materials. Chemsuschem 2009;2(1):99-112. 
184. Bianchini C, Shen PK. Palladium-based electrocatalysts for alcohol oxidation in half cells and in direct alcohol fuel cells. Chemical Reviews 2009;109(9):41834206.

185. EnvironmentalChemistry.com. [Internet]. Periodical Table of Element; 2011 [updated 2011 Dec 2; cited 2012 Jul 21]. Available from: http://environmentalchemistry.com/yogi/periodic/.

186. Du W, Mackenzie KE, Milano DF, Deskins NA, Su D, Teng X. Palladium-tin alloyed catalysts for the ethanol oxidation reaction in an alkaline medium. ACS Catalysis 2012;2(2):287-297.

187. Shen SY, Zhao TS, Xu JB, Li YS. Synthesis of PdNi catalysts for the oxidation of ethanol in alkaline direct ethanol fuel cells. Journal of Power Sources 2010;195(4):1001-1006.

188. Maiyalagan T, Scott K. Performance of carbon nanofiber supported Pd-Ni catalysts for electro-oxidation of ethanol in alkaline medium. Journal of Power Sources 2010;195(16):5246-5251.

189. Bagchi J, Bhattacharya SK. Electrocatalytic activity of binary palladium ruthenium anode catalyst on Ni-support for ethanol alkaline fuel cells. Transition Metal Chemistry 2007;32(1):47-55.

190. Bagchi J, Bhattacharya SK. Studies of the electrocatalytic activity of binary palladium ruthenium anode catalyst on Ni support for ethanol alkaline fuel cells. Transition Metal Chemistry 2008;33(1):113-120. 
191. Liu J, Zhou H, Wang Q, Zeng F, Kuang Y. Reduced graphene oxide supported palladium-silver bimetallic nanoparticles for ethanol electro-oxidation in alkaline media. Journal of Materials Science 2012;47(5):2188-2194.

192. Liu JP, Ye JP, Xu CW, Jiang SP, Tong YX. Kinetics of ethanol electrooxidation at Pd electrodeposited on Ti. Electrochemistry Communications 2007;9(9):23342339.

193. Hu FP, Ding FW, Song SQ, Shen PK. Pd electrocatalyst supported on carbonized $\mathrm{TiO}_{2}$ nanotube for ethanol oxidation. Journal of Power Sources 2006;163(1):415419.

194. Shen PK, Xu CW. Alcohol oxidation on nanocrystalline oxide $\mathrm{Pd} / \mathrm{C}$ promoted electrocatalysts. Electrochemistry Communications 2006;8(1):184-188.

195. Fengping H, Guofeng C, Zidong W, Pei Kang S. Improved kinetics of ethanol oxidation on $\mathrm{Pd}$ catalysts supported on tungsten carbides/carbon nanotubes. Electrochemistry Communications 2008:1303-1306.

196. Hu FP, Shen PK. Ethanol oxidation on hexagonal tungsten carbide single nanocrystal-supported Pd electrocatalyst. Journal of Power Sources 2007;173(2):877-881.

197. Zheng HT, Li YL, Chen SX, Shen PK. Effect of support on the activity of Pd electrocatalyst for ethanol oxidation. Journal of Power Sources 2006;163(1):371375.

198. Qin YH, Yang HH, Zhang XS, Li P, Ma CA. Effect of carbon nanofibers microstructure on electrocatalytic activities of Pd electrocatalysts for ethanol 
oxidation in alkaline medium. International Journal of Hydrogen Energy 2010;35(15):7667-7674.

199. Qin YH, Yang HH, Zhang XS, Li P, Zhou XG, Niu L, Yuan WK. Electrophoretic deposition of network-like carbon nanofibers as a palladium catalyst support for ethanol oxidation in alkaline media. Carbon 2010;48(12):3323-3329.

200. Hu G, Nitze F, Barzegar HR, Sharifi T, Mikołajczuk A, Tai C-W, Borodzinski A, Wågberg T. Palladium nanocrystals supported on helical carbon nanofibers for highly efficient electro-oxidation of formic acid, methanol and ethanol in alkaline electrolytes. Journal of Power Sources 2012;209:236-242.

201. Demirci UB. Theoretical means for searching bimetallic alloys as anode electrocatalysts for direct liquid-feed fuel cells. Journal of Power Sources 2007;173(1):11-18.

202. Lai SCS, Kleijn SEF, Ozturk FTZ, Vellinga VCV, Koning J, Rodriguez P, Koper MTM. Effects of electrolyte $\mathrm{pH}$ and composition on the ethanol electro-oxidation reaction. Catalysis Today 2010;154(1-2):92-104.

203. Lai SCS, Koper MTM. Ethanol electro-oxidation on platinum in alkaline media. Physical Chemistry Chemical Physics 2009;11(44):10446.

204. Santasalo-Aarnio A, Kwon Y, Ahlberg E, Kontturi K, Kallio T, Koper MTM. Comparison of methanol, ethanol and iso-propanol oxidation on Pt and Pd electrodes in alkaline media studied by HPLC. Electrochemistry Communications 2011;13(5):466-469. 
205. Liang ZX, Zhao TS, Xu JB, Zhu LD. Mechanism study of the ethanol oxidation reaction on palladium in alkaline media. Electrochimica Acta 2009;54(8):22032208.

206. Zhou Z-Y, Tian N, Chen Y-J, Chen S-P, Sun S-G. In situ rapid-scan timeresolved microscope FTIR spectroelectrochemistry: study of the dynamic processes of methanol oxidation on a nanostructured Pt electrode. Journal of Electroanalytical Chemistry 2004;573(1):111-119.

207. Fang X, Wang L, Shen PK, Cui G, Bianchini C. An in situ Fourier transform infrared spectroelectrochemical study on ethanol electrooxidation on $\mathrm{Pd}$ in alkaline solution. Journal of Power Sources 2010;195(5):1375-1378.

208. Zhang Z, Xin L, Sun K, Li W. Pd-Ni electrocatalysts for efficient ethanol oxidation reaction in alkaline electrolyte. International Journal of Hydrogen Energy 2011;36(20):12686-12697.

209. Sun SH, Murray CB, Weller D, Folks L, Moser A. Monodisperse FePt nanoparticles and ferromagnetic FePt nanocrystal superlattices. Science 2000;287(5460):1989-1992.

210. Sun SH, Anders S, Thomson T, Baglin JEE, Toney MF, Hamann HF, Murray CB, Terris BD. Controlled synthesis and assembly of FePt nanoparticles. Journal of Physical Chemistry B 2003;107(23):5419-5425.

211. Li WZ, Chen ZW, Xu LB, Yan Y. A solution-phase synthesis method to highly active $\mathrm{Pt}-\mathrm{Co} / \mathrm{C}$ electrocatalysts for proton exchange membrane fuel cell. Journal of Power Sources 2010;195(9):2534-2540. 
212. Zhang ZY, More KL, Sun K, Wu ZL, Li WZ. Preparation and characterization of PdFe nanoleaves as electrocatalysts for oxygen reduction reaction. Chemistry of Materials 2011;23(6):1570-1577.

213. Singh RN, Singh A, Anindita. Electrocatalytic activity of binary and ternary composite films of Pd, MWCNT, and Ni for ethanol electro-oxidation in alkaline solutions. Carbon 2009;47(1):271-278.

214. Medway SL, Lucas CA, Kowal A, Nichols RJ, Johnson D. In situ studies of the oxidation of nickel electrodes in alkaline solution. Journal of Electroanalytical Chemistry 2006;587(1):172-181.

215. Freitas MBJG. Nickel hydroxide powder for $\mathrm{NiO} \cdot \mathrm{OH} / \mathrm{Ni}(\mathrm{OH})_{2}$ electrodes of the alkaline batteries. Journal of Power Sources 2001;93(1-2):163-173.

216. Simoes M, Baranton S, Coutanceau C. Electro-oxidation of glycerol at Pd based nano-catalysts for an application in alkaline fuel cells for chemicals and energy cogeneration. Applied Catalysis B: Environmental 2010;93(3-4):354-362.

217. Xiao L, Lu JT, Liu PF, Zhuang L, Yan JW, Hu YG, Mao BW, Lin CJ. Proton diffusion determination and dual structure model for nickel hydroxide based on potential step measurements on single spherical beads. Journal of Physical Chemistry B 2005;109(9):3860-3867.

218. Wang CB, Gau GY, Gau SJ, Tang CW, Bi JL. Preparation and characterization of nanosized nickel oxide. Catalysis Letters 2005;101(3-4):241-247.

219. Jeong MC, Pyun CH, Yeo IH. Voltammetric studies on the palladium oxides in alkaline media. Journal of the Electrochemical Society 1993;140(7):1986-1989. 
220. Grden M, Lukaszewski M, Jerkiewicz G, Czerwinski A. Electrochemical behaviour of palladium electrode: Oxidation, electrodissolution and ionic adsorption. Electrochimica Acta 2008;53(26):7583-7598.

221. Wang L, Bambagioni V, Bevilacqua M, Bianchini C, Filippi J, Lavacchi A, Marchionni A, Vizza F, Fang X, Shen PK. Sodium borohydride as an additive to enhance the performance of direct ethanol fuel cells. Journal of Power Sources 2010;195(24):8036-8043.

222. Hu FP, Wang Z, Li Y, Li C, Zhang X, Shen PK. Improved performance of Pd electrocatalyst supported on ultrahigh surface area hollow carbon spheres for direct alcohol fuel cells. Journal of Power Sources 2008;177(1):61-66.

223. Xu CW, Wang H, Shen PK, Jiang SP. Highly ordered Pd nanowire arrays as effective electrocatalysts for ethanol oxidation in direct alcohol fuel cells. Advanced Materials 2007;19(23):4256-4259.

224. Durandkeklikian L, Haq I, Matijevic E. Preparation and characterization of welldefined colloidal nickel compounds. Colloids and Surfaces a-Physicochemical and Engineering Aspects 1994;92(3):267-275.

225. Parks GA. The isoelectric points of solid oxides, solid hydroxides, and aqueous hydroxo complex systems. Chemical Reviews 1965;65(2):177-198.

226. Moriwaki H, Yoshikawa Y, Morimoto T. Oxide-films on iron and nickel ultrafine particles studied with zero-point of charge measurements. Langmuir 1990;6(4):847-850.

227. Huber GW, Iborra S, Corma A. Synthesis of transportation fuels from biomass: Chemistry, catalysts, and engineering. Chemical Reviews 2006;106(9):4044-4098. 
228. Kamat PV. Meeting the clean energy demand: Nanostructure architectures for solar energy conversion. Journal of Physical Chemistry C 2007;111(7):2834-2860.

229. Aricò AS, Baglio V, Antonucci V. Direct methanol fuel cells: History, status and perspectives. In: Zhang JJ, Liu HS, editors. Electrocatalysis of Direct Methanol Fuel Cells. Germany: Wiley-VCH Verlag GmbH \& Co. KGaA; 2009. p 1-78.

230. Kim HJ, Choi SM, Green S, Tompsett GA, Lee SH, Huber GW, Kim WB. Highly active and stable PtRuSn/C catalyst for electrooxidations of ethylene glycol and glycerol. Applied Catalysis B: Environmental 2011;101(3-4):366-375.

231. Kahyaoglu A, Beden B, Lamy C. Oxydation electrocatalitique du glycerol sur electrodes d'or et de platine en milieu aqueux. Electrochimica Acta 1984;29(10):1489-1492.

232. Roquet L, Belgsir EM, Leger JM, Lamy C. Kinetics and mechanisms of the electrocatalytic oxidation of glycerol as investigated by chromatographic analysis of the reaction-products - potential and $\mathrm{Ph}$ effects. Electrochimica Acta 1994;39(16):2387-2394.

233. Bambagioni V, Bianchini C, Marchionni A, Filippi J, Vizza F, Teddy J, Serp P, Zhiani M. Pd and Pt-Ru anode electrocatalysts supported on multi-walled carbon nanotubes and their use in passive and active direct alcohol fuel cells with an anion-exchange membrane (alcohol $=$ methanol, ethanol, glycerol). Journal of Power Sources 2009;190(2):241-251.

234. Su L, Jia WZ, Schempf A, Lei Y. Palladium/titanium dioxide nanofibers for glycerol electrooxidation in alkaline medium. Electrochemistry Communications 2009;11(11):2199-2202. 
235. Zhang J-h, Liang Y-j, Li N, Li Z-y, Xu C-w, Jiang SP. A remarkable activity of glycerol electrooxidation on gold in alkaline medium. Electrochimica Acta 2012;59:156-159.

236. Matsuoka K, Iriyama Y, Abe T, Matsuoka M, Ogumi Z. Alkaline direct alcohol fuel cells using an anion exchange membrane. Journal of Power Sources $2005 ; 150: 27-31$.

237. Ilie A, Simoes M, Baranton S, Coutanceau C, Martemianov S. Influence of operational parameters and of catalytic materials on electrical performance of direct glycerol solid alkaline membrane fuel cells. Journal of Power Sources 2011;196(11):4965-4971.

238. Xin L, Zhang ZY, Wang ZC, Li WZ. Simultaneous generation of mesoxalic acid and electricity from glycerol on Au anode catalyst in anion-exchange membrane fuel cells. ChemCatChem 2012;4(8):1105-1114.

239. Jeffery DZ, Camara GA. The formation of carbon dioxide during glycerol electrooxidation in alkaline media: First spectroscopic evidences. Electrochemistry Communications 2010;12(8):1129-1132.

240. Gomes J, Tremiliosi-Filho G. Spectroscopic Studies of the glycerol electrooxidation on polycrystalline $\mathrm{Au}$ and $\mathrm{Pt}$ surfaces in acidic and alkaline Media. Electrocatalysis 2011;2(2):96-105.

241. Burke LD, Moran J, Nugent P. Cyclic voltammetry responses of metastable gold electrodes in aqueous media. Journal of Solid State Electrochemistry 2003;7(9):529-538. 
242. Bianchi CL, Canton P, Dimitratos N, Porta F, Prati L. Selective oxidation of glycerol with oxygen using mono and bimetallic catalysts based on $\mathrm{Au}, \mathrm{Pd}$ and $\mathrm{Pt}$ metals. Catalysis Today 2005;102:203-212.

243. Yan $\mathrm{S}$, Zhang $\mathrm{S}$. Investigation of methanol electrooxidation on $\mathrm{Au} / \mathrm{C}$ catalyst in alkaline medium. International Journal of Hydrogen Energy 2011;36(21):1339213397.

244. Carrettin S, McMorn P, Johnston P, Griffin K, Kiely CJ, Attard GA, Hutchings GJ. Oxidation of glycerol using supported gold catalysts. Topics in Catalysis 2004;27(1-4):131-136.

245. de Lima RB, Varela H. Catalytic oxidation of ethanol on gold electrode in alkaline media. Gold Bulletin 2008;41(1):15-22.

246. Arechederra RL, Treu BL, Minteer SD. Development of glycerol $/ \mathrm{O}_{2}$ biofuel cell. Journal of Power Sources 2007;173(1):156-161.

247. Arechederra RL, Minteer SD. Complete oxidation of glycerol in an enzymatic biofuel cell. Fuel Cells 2009;9(1):63-69.

248. Ketchie W, Fang Y, Wong M, Murayama M, Davis R. Influence of gold particle size on the aqueous-phase oxidation of carbon monoxide and glycerol. Journal of Catalysis 2007;250(1):94-101.

249. Carrettin S, McMorn P, Johnston P, Griffin K, Kiely CJ, Hutchings GJ. Oxidation of glycerol using supported Pt, Pd and Au catalysts. Physical Chemistry Chemical Physics 2003;5(6):1329-1336. 
250. Hekmat D, Bauer R. Development of a transient segregated mathematical model of the semicontinuous microbial production process of dihydroxyacetone. Biotechnology Progress 2006;22(1):278-284.

251. Garcia R, Besson M, Gallezot P. Chemoselective catalytic oxidation of glycerol with air on platinum metals. Applied Catalysis A: General 1995;127(1-2):165-176.

252. Gao J, Liang D, Chen P, Hou ZY, Zheng XM. Oxidation of glycerol with oxygen in a base-free aqueous solution over Pt/AC and Pt/MWNTs catalysts. Catalysis Letters 2009;130(1-2):185-191.

253. Liang D, Gao J, Wang JH, Chen P, Hou ZY, Zheng XM. Selective oxidation of glycerol in a base-free aqueous solution over different sized Pt catalysts. Catalysis Communications 2009;10(12):1586-1590.

254. Dimitratos N, Porta F, Prati L. Au, Pd (mono and bimetallic) catalysts supported on graphite using the immobilisation method - Synthesis and catalytic testing for liquid phase oxidation of glycerol. Applied Catalysis A: General 2005;291(12):210-214.

255. Abad A, Concepción P, Corma A, García H. A Collaborative Effect between Gold and a Support Induces the Selective Oxidation of Alcohols. Angewandte Chemie International Edition 2005;44(26):4066-4069.

256. Hughes MD, Xu Y-J, Jenkins P, McMorn P, Landon P, Enache DI, Carley AF, Attard GA, Hutchings GJ, King F and others. Tunable gold catalysts for selective hydrocarbon oxidation under mild conditions. Nature 2005;437(7062):1132-1135.

257. Villa A, Wang D, Su DS, Prati L. Gold sols as catalysts for glycerol oxidation: The role of stabilizer. Chemcatchem 2009;1(4):510-514. 
258. Villa A, Gaiassi A, Rossetti I, Bianchi CL, van Benthem K, Veith GM, Prati L. $\mathrm{Au}$ on MgAl2O4 spinels: The effect of support surface properties in glycerol oxidation. Journal of Catalysis 2010;275(1):108-116.

259. Villa A, Veith GM, Prati L. Selective oxidation of glycerol under acidic conditions using gold catalysts. Angewandte Chemie International Edition 2010;49(26):4499-4502.

260. Rodrigues EG, Pereira MFR, Chen X, Delgado JJ, Orfao JJM. Influence of activated carbon surface chemistry on the activity of $\mathrm{Au} / \mathrm{AC}$ catalysts in glycerol oxidation. Journal of Catalysis 2011;281(1):119-127.

261. Grace AN, Pandian K. Pt, Pt-Pd and Pt-Pd/Ru nanoparticles entrapped polyaniline electrodes - A potent electrocatalyst towards the oxidation of glycerol. Electrochemistry Communications 2006;8(8):1340-1348.

262. Shen YH, Zhang SH, Li HJ, Ren Y, Liu HC. Efficient synthesis of lactic acid by aerobic oxidation of glycerol on $\mathrm{Au}-\mathrm{Pt} / \mathrm{TiO}_{2}$ Catalysts. Chemistry-a European Journal 2010;16(25):7368-7371.

263. Brett GL, He Q, Hammond C, Miedziak PJ, Dimitratos N, Sankar M, Herzing AA, Conte M, Lopez-Sanchez JA, Kiely CJ and others. Selective oxidation of glycerol by highly active bimetallic catalysts at ambient temperature under base-free conditions. Angewandte Chemie International Edition 2011;50(43):10136-10139.

264. Dimitratos N, Messi C, Porta F, Prati L, Villa A. Investigation on the behaviour of $\operatorname{Pt}(0) /$ carbon and $\operatorname{Pt}(0), \operatorname{Au}(0) /$ carbon catalysts employed in the oxidation of glycerol with molecular oxygen in water. Journal of Molecular Catalysis A: Chemical 2006;256(1-2):21-28. 
265. Ketchie W, Murayama M, Davis R. Selective oxidation of glycerol over carbonsupported AuPd catalysts. Journal of Catalysis 2007;250(2):264-273.

266. Dimitratos N, Lopez-Sanchez JA, Anthonykutty JM, Brett G, Carley AF, Tiruvalam RC, Herzing AA, Kiely CJ, Knight DW, Hutchings GJ. Oxidation of glycerol using gold-palladium alloy-supported nanocrystals. Physical Chemistry Chemical Physics 2009;11(25):4952-4961.

267. Dimitratos N, Villa A, Prati L. Liquid phase oxidation of glycerol using a single phase (Au-Pd) alloy supported on activated carbon: Effect of reaction conditions. Catalysis Letters 2009;133(3-4):334-340.

268. Wang D, Villa A, Porta F, Prati L, Su DS. Bimetallic gold/palladium catalysts: Correlation between nanostructure and synergistic effects. Journal of Physical Chemistry C 2008;112(23):8617-8622.

269. Hu W, Lowry B, Varma A. Kinetic study of glycerol oxidation network over PtBi/C catalyst. Applied Catalysis B: Environmental 2011;106(1-2):123-132.

270. Liang D, Gao J, Wang J, Chen P, Wei Y, Hou Z. Bimetallic Pt-Cu catalysts for glycerol oxidation with oxygen in a base-free aqueous solution. Catalysis Communications 2011;12(12):1059-1062.

271. Simões M, Baranton S, Coutanceau C. Enhancement of catalytic properties for glycerol electrooxidation on $\mathrm{Pt}$ and $\mathrm{Pd}$ nanoparticles induced by $\mathrm{Bi}$ surface modification. Applied Catalysis B: Environmental 2011;110(0):40-49.

272. Besson M, Gallezot P. Selective oxidation of alcohols and aldehydes on metal catalysts. Catalysis Today 2000;57(1-2):127-141. 
273. Fordham P, Besson M, Gallezot P. Catalytic oxidation with air of tartronic acid to mesoxalic acid on bismuth-promoted platinum. Catalysis Letters 1997;46(34):195-199.

274. Bunazawa H, Yamazaki Y. Influence of anion ionomer content and silver cathode catalyst on the performance of alkaline membrane electrode assemblies (MEAs) for direct methanol fuel cells (DMFCs). Journal of Power Sources 2008;182(1):48-51.

275. Bambagioni V, Bevilacqua M, Bianchini C, Filippi J, Lavacchi A, Marchionni A, Vizza F, Shen PK. Self-sustainable production of hydrogen, chemicals, and energy from renewable alcohols by electrocatalysis. Chemsuschem 2010;3(7):851-855.

276. Bizot PM, Bailey BR, Hicks PD, inventros; Nalco Chemical Company, assignee. Use of tartronic acid as an oxygen scavenger. US patent 5,750,037. 1998 May 12.

277. Davis WR, Tomsho J, Nikam S, Cook EM, Somand D, Peliska JA. Inhibition of HIV-1 Reverse Transcriptase-Catalyzed DNA Strand Transfer Reactions by 4Chlorophenylhydrazone of Mesoxalic Acid. Biochemistry 2000;39(46):1427914291.

278. Ohshima T, Yamamoto Y, Takaki U, Inoue Y, Saeki T, Itou K, Maegawa Y, Iwasaki $\mathrm{T}$, Mashima $\mathrm{K}$. Theoretical study of $\mathrm{Al}(\mathrm{III})$-catalyzed conversion of glyoxal to glycolic acid: dual activated 1,2-hydride shift mechanism by protonated $\mathrm{Al}(\mathrm{OH})_{3}$ species. Chemical Communications 2009(19):2688-2690. 
279. Panova A, Mersinger LJ, Liu Q, Foo T, Roe DC, Spillan WL, Sigmund AE, BenBassat A, Wagner LW, O'Keefe DP and others. Chemoenzymatic synthesis of glycolic acid. Advanced Synthesis \& Catalysis 2007;349(8-9):1462-1474.

280. Hayes MJ, Lauren MD. Chemical stress-relaxation of polyglycolic acid suture. Journal of Applied Biomaterials 1994;5(3):215-220.

281. Shawe S, Buchanan F, Harkin-Jones E, Farrar D. A study on the rate of degradation of the bioabsorbable polymer polyglycolic acid (PGA). Journal of Materials Science 2006;41(15):4832-4838.

282. Park J-H, Allen MG, Prausnitz MR. Biodegradable polymer microneedles: Fabrication, mechanics and transdermal drug delivery. Journal of Controlled Release 2005;104(1):51-66.

283. Wada M, Mochizuki D, Takahashi H, Morishige T, Takahashi K, inventors; Mitsui Chemicals Inc., assignee. Process for producing hydroxycarboxylic acid. WO 2,005,106,005. 2005 Nov 10.

284. Larson AT, inventors; E. I. du Pont de Nemours \& Company, assignee. Process for the preparation of glycolic acid. US patent 2,153,064. 1939 Apr 4.

285. Loder DJ, inventors; E. I. du Pont de Nemours \& Company, assignee. Process for Manufacture of Glycolic Acid US patent 2,152,852. 1939 Apr 4.

286. Shattuck MT, inventors; E. I. du Pont de Nemours \& Company, assignee. Continuous glycolic acid process. US patent 2,443,482. 1948 Jun 15.

287. Lapporte SJ, Toland WG, inventors; Chevron Research Company, assignee. Glycolic acid production. US patent 3,754,028. 1973 Aug 21. 
288. Scardigno S, Rivolta L, Caprars G, Cassar L, inventors; Montedison S.p.A., Milan, Italy, assignee. Process for Preparing glycolic acid and its polymers. US patent 4,052,452. 1977 Oct 4 .

289. DiCosimo R, Panova A, Thompson JS, Fallon RD, Gallagher FG, Foo T, Li X, Fox GC, Zaher JJ, Payne MS, O'Keefe DP, inventros; E. I. du Pont de Nemours and Company, assignee. Process for producing glycolic acid from formaldehyde and hydrogen cyanide. US patent 7,939,303 B2. 2011 May 10.

290. Hinago H, Nagahara H, Aoki T, inventors; Asohi Kasei Chemicals corporation, assignee. Method for producing glycolic acid. US patent 8,106,238 B2. 2012 Jan 31.

291. Ben-Bassat A, Walls AM, Plummer MA, Sigmund AE, Spillan WL, DiCosimo R. Optimization of biocatalyst specific activity for glycolic acid production. Advanced Synthesis \& Catalysis 2008;350(11-12):1761-1769.

292. Corma A, Iborra S, Velty A. Chemical routes for the transformation of biomass into chemicals. Chemical Reviews 2007;107(6):2411-2502.

293. Hashmi ASK, Hutchings GJ. Gold catalysis. Angewandte Chemie International Edition 2006;45(47):7896-7936.

294. Dimitratos N, Lopez-Sanchez J, Lennon D, Porta F, Prati L, Villa A. Effect of particle size on monometallic and bimetallic $(\mathrm{Au}, \mathrm{Pd}) / \mathrm{C}$ on the liquid phase oxidation of glycerol. Catalysis Letters 2006;108(3):147-153.

295. Che G, Lakshmi BB, Fisher ER, Martin CR. Carbon nanotubule membranes for electrochemical energy storage and production. Nature 1998;393(6683):346-349. 
296. Li WZ, Wang X, Chen ZW, Waje M, Yan YS. Pt-Ru supported on double-walled carbon nanotubes as high-performance anode catalysts for direct methanol fuel cells. Journal of Physical Chemistry B 2006;110(31):15353-15358.

297. Wang X, Li WZ, Chen ZW, Waje M, Yan YS. Durability investigation of carbon nanotube as catalyst support for proton exchange membrane fuel cell. Journal of Power Sources 2006;158(1):154-159.

298. Tang JM, Jensen K, Waje M, Li W, Larsen P, Pauley K, Chen Z, Ramesh P, Itkis ME, Yan Y and others. High performance hydrogen fuel cells with ultralow Pt loading carbon nanotube thin film catalysts. Journal of Physical Chemistry C 2007;111(48):17901-17904.

299. Zhang ZY, Xin L, Li WZ. Supported gold nanoparticles as anode catalyst for anion-exchange membrane-direct glycerol fuel cell (AEM-DGFC). International Journal of Hydrogen Energy 2012;37(11):9393-9401. 


\section{Appendix A Copyright permission of Fig 1.1}

Fig. 1.1 used in Chapter 1 of this dissertation was initially published on wesite: https://flowcharts.1lnl.gov/content/energy/energy archive/energy flow_2010/LLNLUSE nergy2010.png. A copy of the granting permission for reproduction is shown below.

Zhiyong Zhang

$\begin{array}{ll}\text { From: } & \text { Simon, A.J. } \\ \text { Sent: } & \text { 2012年8月15日星期三 16:41 } \\ \text { To: } & \text { Zhiyong Zhang } \\ \text { Subject: } & \text { RE: Ask for the permission of reusing a figure from your website }\end{array}$

Dear Zhiyong,

Yes, you may use that figure. It is licensed for unlimited reproduction.

We only ask that you credit LLNL when you use it.

-A.J.

From: Zhiyong Zhang [mailto:zhiyong@mtu.edu]

Sent: Wednesday, August 15, 2012 11:22 AM

To: ajsimon@\|lnl.gov

Subject: Ask for the permission of reusing a figure from your website

Dear Sir or Madam,

This is Zhiyong Zhang, and a Ph.D candidate in Chemical Engineering Department, Michigan Technological University. I am writing to ask for your permission of using a "U.S. Energy Flow" figure in my Ph.D dissertation. The figure was initially published on your website,"

https://flowcharts.llnl.gov/content/energy/energy archive/energy flow 2010/LLNLUSEnergy2010.png".

I look forward to hearing from you.

Best Regards,

Zhiyong

$* * * * * * * * * * * * * * * * * * * * * * * * * * * * * * * * * * * *$

Zhiyong Zhang (智勇 张)

Ph.D Candidate

Room 401, Chem-Sci Building

Department of Chemical Engineering

Michigan Technological University

phone:(906)370-6673

email:zhivong@mtu.edu

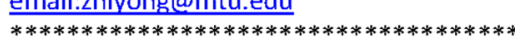




\section{Appendix B Copyright permission of Fig 3.2}

Fig. 3.2 used in Chapter 3 of this dissertation was initially published in Surface Science Reports, "Surface science studies of model fuel cell electrocatalysts", Volume 45, 2002, 121-229. Permission to reuse material from the published work was obtained with kind permission from Elsevier. A copy of the granting permission for reproduction is shown below.

This is a License Agreement between Zhiyong Zhang ("You") and Elsevier ("Elsevier") provided by Copyright Clearance Center ("CCC"). The license consists of your order details, the terms and conditions provided by Elsevier, and the payment terms and conditions.

Supplier

Registered Company Number

Customer name

Customer address

License number

License date

Licensed content publisher

Licensed content publication

Licensed content title

Licensed content author

Licensed content date

Licensed content volume number

Licensed content issue number

Number of pages
Elsevier Limited

The Boulevard,Langford Lane

Kidlington,Oxford,OX5 1GB,UK

1982084

Zhiyong Zhang

Rm 401, Bldg 19, 1400 Townsend Drive

Houghton, MI 49931

2970350938160

Aug 15, 2012

Elsevier

Surface Science Reports

Surface science studies of model fuel cell electrocatalysts

N.M. Marković,P.N. Ross

April 2002

45

4-6

113 
Start Page

End Page

Type of Use

Portion

Number of figures/tables/illustrations

Format

Are you the author of this Elsevier article?

Will you be translating?

Order reference number

Title of your thesis/dissertation

Expected completion date

Estimated size (number of pages)

Elsevier VAT number

Permissions price

VAT/Local Sales Tax

Total
117

229

reuse in a thesis/dissertation

figures/tables/illustrations

1

both print and electronic

No

No

Advanced nanostructured electro-catalysts for electricity generation and biorenewable alcohol conversion

Aug 2012

200

GB 494627212

0.00 USD

$0.0 \mathrm{USD} / 0.0 \mathrm{GBP}$

0.00 USD 


\section{Appendix C Copyright permission of Fig. 3.3}

Fig. 3.3 used in Chapter 3 of this dissertation was initially published in Topics in Catalysis, "Instability of Supported Platinum Nanoparticles in Low-Temperature Fuel Cells", Volume 46, 2007, 285-305. Permission to reuse material from the published work was obtained with kind permission from Springer. A copy of the granting permission for reproduction is shown below.

This is a License Agreement between Zhiyong Zhang ("You") and Springer ("Springer") provided by Copyright Clearance Center ("CCC"). The license consists of your order details, the terms and conditions provided by Springer, and the payment terms and conditions.

License Number

License date

Licensed content publisher

Licensed content publication

Licensed content title

Licensed content author

Licensed content date

Volume number

Issue number

Type of Use

Portion

Author of this Springer article

Order reference number
2970351264434

Aug 15, 2012

Springer

Topics in Catalysis

Instability of Supported Platinum Nanoparticles in Low-Temperature Fuel Cells

Y. Shao-Horn

Dec 1, 2007

46

3

Thesis/Dissertation

Figures

No 
Title of your thesis /dissertation

Expected completion date

Estimated size (pages)

Total 0.00 USD
Advanced nanostructured electro-catalysts for electricity generation and biorenewable alcohol conversion

Aug 2012

200 


\section{Appendix D Copyright permission of Fig. 4.1}

Fig. 4.1 used in Chapter 4 of this dissertation was initially published in Electrochimica Acta, "Oxygen electrocatalysis in alkaline electrolyte: Pt(hkl), Au(hkl) and the effect of Pd-modification", Volume 47, 2002, 3765-3776. Permission to reuse material from the published work was obtained with kind permission from Elsevier. A copy of the granting permission for reproduction is shown below.

This is a License Agreement between Zhiyong Zhang ("You") and Elsevier ("Elsevier") provided by Copyright Clearance Center ("CCC"). The license consists of your order details, the terms and conditions provided by Elsevier, and the payment terms and conditions.

Supplier

Registered Company Number

Customer name

Customer address

License number

License date

Licensed content publisher

Licensed content publication

Licensed content title

Licensed content author

Licensed content date
Elsevier Limited

The Boulevard,Langford Lane

Kidlington,Oxford,OX5 1GB,UK

1982084

Zhiyong Zhang

Rm 401, Bldg 19, 1400 Townsend Drive

Houghton, MI 49931

2970351471033

Aug 15, 2012

Elsevier

Electrochimica Acta

Oxygen electrocatalysis in alkaline electrolyte: Pt(hkl), Au(hkl) and the effect of Pd-modification

T.J. Schmidt,V. Stamenkovic,M. Arenz,N.M. Markovic,P.N. Ross

30 August 2002 
Licensed content volume number

Licensed content issue number

Number of pages

Start Page

End Page

Type of Use

Intended publisher of new work

Portion

Number of figures/tables/illustrations

Format

Are you the author of this Elsevier article?

Will you be translating?

Order reference number

Title of your thesis/dissertation

Expected completion date

Estimated size (number of pages)

Elsevier VAT number

Permissions price

VAT/Local Sales Tax

Total
47

$22-23$

12

3765

3776

reuse in a thesis/dissertation

other

figures/tables/illustrations

1

both print and electronic

No

No

Advanced nanostructured electro-catalysts for electricity generation and biorenewable alcohol conversion

Aug 2012

200

GB 494627212

0.00 USD

$0.0 \mathrm{USD} / 0.0 \mathrm{GBP}$

0.00 USD 


\section{Appendix E Copyright permission of Fig. 6.1}

Fig. 6.1 used in Chapter 6 of this dissertation was initially published in Topics in Catalysis, "Electro-oxidation of glycerol at Pd based nano-catalysts for an application in alkaline fuel cells for chemicals and energy cogeneration”, Volume 93, 2010, 354-362. Permission to reuse material from the published work was obtained with kind permission from Elsevier. A copy of the granting permission for reproduction is shown below.

This is a License Agreement between Zhiyong Zhang ("You") and Elsevier ("Elsevier") provided by Copyright Clearance Center ("CCC"). The license consists of your order details, the terms and conditions provided by Elsevier, and the payment terms and conditions

Supplier

Registered Company Number

Customer name

Customer address

License number

License date

Licensed content publisher

Licensed content publication

Licensed content title

Licensed content author
Elsevier Limited

The Boulevard,Langford Lane

Kidlington,Oxford,OX5 1GB,UK

1982084

Zhiyong Zhang

Rm 401, Bldg 19, 1400 Townsend Drive

Houghton, MI 49931

2970360201305

Aug 15, 2012

Elsevier

Applied Catalysis B: Environmental

Electro-oxidation of glycerol at $\mathrm{Pd}$ based nano-catalysts for an application in alkaline fuel cells for chemicals and energy cogeneration

Mario Simoes, Steve Baranton, Christophe Coutanceau 
Licensed content date

Licensed content volume number

Licensed content issue number

Number of pages

Start Page

End Page

Type of Use

Intended publisher of new work

Portion

Number of figures/tables/illustrations

Format

Are you the author of this Elsevier article?

Will you be translating?

Order reference number

Title of your thesis/dissertation

Expected completion date

Estimated size (number of pages)

Elsevier VAT number

Permissions price

VAT/Local Sales Tax

Total
12 January 2010

93

3-4

9

354

362

reuse in a thesis/dissertation

other

figures/tables/illustrations

1

both print and electronic

No

No

Advanced nanostructured electro-catalysts for electricity generation and biorenewable alcohol conversion

Aug 2012

200

GB 494627212

0.00 USD

$0.0 \mathrm{USD} / 0.0 \mathrm{GBP}$

0.00 USD 


\section{Appendix F Copyright permission of Fig. 6.2}

Fig. 6.2 used in Chapter 6 of this dissertation was initially published in Topics in Catalysis, "Mechanism of the Catalytic Oxidation of Glycerol on Polycrystalline Gold and Platinum Electrodes", Volume 3, 2011, 1176-1185. Permission to reuse material from the published work was obtained with kind permission from John Wiley and Sons. A copy of the granting permission for reproduction is shown below.

This is a License Agreement between Zhiyong Zhang ("You") and John Wiley and Sons ("John Wiley and Sons") provided by Copyright Clearance Center ("CCC"). The license consists of your order details, the terms and conditions provided by John Wiley and Sons, and the payment terms and conditions.

License Number

License date

Licensed content publisher

Licensed content publication

Licensed content title

Licensed content author

Licensed content date

Start page

End page

Type of use

Requestor type

Format

Portion

Number of figures/tables
2970360678176

Aug 15, 2012

John Wiley and Sons

ChemCatChem

Mechanism of the Catalytic Oxidation of Glycerol on Polycrystalline Gold and Platinum Electrodes

Youngkook Kwon, Klaas Jan P. Schouten, Marc T. M. Koper

May 27, 2011

1176

1185

Dissertation/Thesis

University/Academic

Print and electronic

Figure/table

1 
Number of extracts

Original Wiley figure/table number(s) Scheme 1

Will you be translating?

No

Order reference number

Total

0.00 USD 


\section{Appendix G Copyright permission of Chapter 3}

Chapter 3 in this dissertation was initially published in Nanotechnology, "Ultra-thin PtFe-nanowires as durable electrocatalysts for fuel cells", Volume 22, 2011, 015602. Permission to reuse material from the published work was obtained with kind permission from IOP Publishing Ltd. A copy of the granting permission for reproduction is shown below. 
To: info@ioppubusa.com

From: Zhiyong Zhang <zhlyongemtu.edu>

Date: 08/21/2012 01:52PM

Subject: Asking for reuse permission of my arbicie in Nanotochnology

To whom it may concern,

I am Zhlyong Zhang, and a Ph.D candidate in Chemical Engineering Department, Michigan Technological university, $f$ am preparing my Ph.D dissertation titled "Advanced nanostructured electro-catalysts for electncily generation and biorenewable alcohol conversion". I would appreciate permission to reproduce the full article "Ultra-thin PtF-o-nanowires as durable electrocatalysts for fuel cells" I initally published in Nanclechnology 2011; 22(1), 015602 DOI: 10.1088/0957-4484/22/1/1515002. It witit be used in both print and electronic ediltona of my dissertation.

I am the first author of this publication.

Thank you for your prompt aftertion to this request.

Yours sincerely

Zhlyong

\section{Zhiyong Zhang (it)}

Ph.D Candidate

Room 401, Chem-Scl Bullding

Department of Chemical Engineering

Michigan Technological University

phone:(906)370-6673

emailizhivengentu.edu

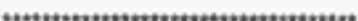

PERMISSION TO REPRODUCE AS REQUESTED IS GNEN PROVIDED THAT:

(0) the eencent of the auther(e) Ho obtained

(b) the source of the material including author, title of article, title of journal, volume number, issue number (If relevant), page range (or first page if this is the only information avallable), date and publisher is acknowledged.

DOI).

\section{IOP Publishing Lidd \\ Temple Circus Temple Way BRISTOL \\ BS1 6BE}

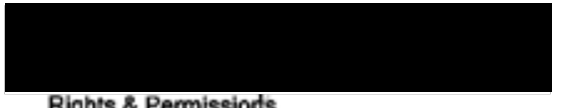

Rights \& Permissionts 


\section{Appendix H Copyright permission of Chapter 4}

Chapter 4 in this dissertation was initially published in Chemistry of Materials, "Preparation and Characterization of PdFe Nanoleaves as Electrocatalysts for Oxygen Reduction Reaction", Volume 23, 2011, 1570-1577. Permission to reuse material from the published work was obtained with kind permission from American Chemical Society. A copy of the granting permission for reproduction is shown below.

Title:

Preparation and Characterization of $\mathrm{PdFe}$ Nanoleaves as Electrocatalysts for Oxygen Reduction Reaction

Author: Zhiyong Zhang, Karren L. More, Kai Sun, Zili $\mathrm{Wu}$, and Wenzhen $\mathrm{Li}$

Publication: Chemistry of Materials

Publisher: American Chemical Society

Date:

Mar 1, 2011

Copyright . 2011, American Chemical Society

\section{PERMISSION/LICENSE IS GRANTED FOR YOUR ORDER AT NO CHARGE}

This type of permission/license, instead of the standard Terms \& Conditions, is sent to you because no fee is being charged for your order. Please note the following:

Permission is granted for your request in both print and electronic formats, and translations.

If figures and/or tables were requested, they may be adapted or used in part.

Please print this page for your records and send a copy of it to your publisher/graduate school. 
Appropriate credit for the requested material should be given as follows: "Reprinted (adapted) with permission from (COMPLETE REFERENCE CITATION). Copyright (YEAR) American Chemical Society." Insert appropriate information in place of the capitalized words.

One-time permission is granted only for the use specified in your request. No additional uses are granted (such as derivative works or other editions). For any other uses, please submit a new request. 


\section{Appendix I Copyright permission of Chapter 5 and 6}

Chapter 5 in this dissertation was initially published in International Journal of Hydrogen Energy, "Pd-Ni electrocatalysts for efficient ethanol oxidation reaction in alkaline electrolyte", Volume 36, 2011, 12686-12697. Chapter 6 in this dissertation was initially published in International Journal of Hydrogen Energy, "Supported gold nanoparticles as anode catalyst for anion-exchange membrane-direct glycerol fuel cell (AEM-DGFC)", Volume 37, 2012, 9393-9401. Permission to reuse material from the published work was obtained with kind permission from the International Association for Hydrogen Energy. A copy of the granting permission for reproduction is shown below.

To: Zhiyong Zhang [zhiyong@mtu.edu]

Cc: Emre A. Veziroglu [emrev1@cox.net]

Subject: Copyright Permission

Dear Zhiyong:

Thank you very much for your email of 16 August 2012. In accordance with your request, we are happy to give you permission to reproduce both in print and also electronically the following articles for your Ph.D. Thesis entitled "Advanced nanostructured electrocatalysts for electricity generation and biorenewable alcohol conversion":

"Pd-Ni electrocatalysts for efficient ethanol oxidation reaction in alkaline electrolyte", published in International Journal of Hydrogen Energy, 2011, 36, 12686-12697. The authors are Zhang, Zhiyong; Xin, Le; Sun, Kai; and Li, Wenzhen. DOI: 10.1016/j.jijhydene.2011.06.141 
"Supported gold nanoparticles as anode catalyst for anion-exchange membrane-direct glycerol fuel cell (AEM-DGFC)", published in International Journal of Hydrogen Energy, 2012, 37, 9393-9401. The authors are Zhang, Zhiyong; Xin, Le; and Li, Wenzhen. DOI: 10.1016/j.ijhydene.2012.03.019

Wishing you all the best in your endeavors, I remain

Sincerely yours,

T. Nejat Veziroglu

Founding Editor-in-Chief

International Journal of Hydrogen Energy (IJHE)

5794 SW 40 St. \#303

Miami, Fl 33155, USA

Tel: $1-305-456-9353$

Fax: 1-305-675-3295

Email: veziroglu@,iahe.org 


\section{Appendix J Copyright permission of Chapter 7}

Chapter 7 in this dissertation was initially published in Applied Catalysis B: Environmental, "Electrocatalytic oxidation of glycerol on $\mathrm{Pt} / \mathrm{C}$ in anion-exchange membrane fuel cell: Cogeneration of electricity and valuable chemicals", Volume 119$120,2012,40-48$. Permission to reuse material from the published work was obtained with kind permission from Elsevier. A copy of the granting permission for reproduction is shown below.

This is a License Agreement between Zhiyong Zhang ("You") and Elsevier ("Elsevier") provided by Copyright Clearance Center ("CCC"). The license consists of your order details, the terms and conditions provided by Elsevier, and the payment terms and conditions.

Supplier

Registered Company Number

Customer name

Customer address

License number

License date

Licensed content publisher

Licensed content publication

Licensed content title

Licensed content author
Elsevier Limited

The Boulevard,Langford Lane

Kidlington,Oxford,OX5 1GB,UK

1982084

Zhiyong Zhang

Rm 401, Bldg 19, 1400 Townsend Drive

Houghton, MI 49931

2970941501937

Aug 16, 2012

Elsevier

Applied Catalysis B: Environmental

Electrocatalytic oxidation of glycerol on $\mathrm{Pt} / \mathrm{C}$ in anion-exchange membrane fuel cell: Cogeneration of electricity and valuable chemicals

Zhiyong Zhang,Le Xin,Wenzhen Li 
Licensed content

Licensed content volume number

Licensed content issue number

Number of pages

Start Page

End Page

Type of Use

Intended publisher of new work

Portion

Format

Are you the author of this Elsevier article?

Will you be translating?

Order reference number

Title of your thesis/dissertation

Expected completion date

Estimated size (number of pages)

Elsevier VAT number

Permissions price

VAT/Local Sales Tax

Total date 30 May 2012

119-120

9

40

48

reuse in a thesis/dissertation

other

full article

both print and electronic

Yes

No

Advanced nanostructured electro-catalysts for electricity generation and biorenewable alcohol conversion

Aug 2012

200

GB 494627212

0.00 USD

$0.0 \mathrm{USD} / 0.0 \mathrm{GBP}$

0.00 USD 


\section{Appendix K Copyright permission of Chapter 8}

Chapter 8 in this dissertation was initially published in Green Chemistry: Environmental, "Selective electro-conversion of glycerol to glycolate on carbon nanotube supported gold catalyst", Volume 14, 2012, 2150-2152. Permission to reuse material from the published work was obtained with kind permission from The Royal Society of Chemistry. A copyright term regarding the reproduction is shown below.

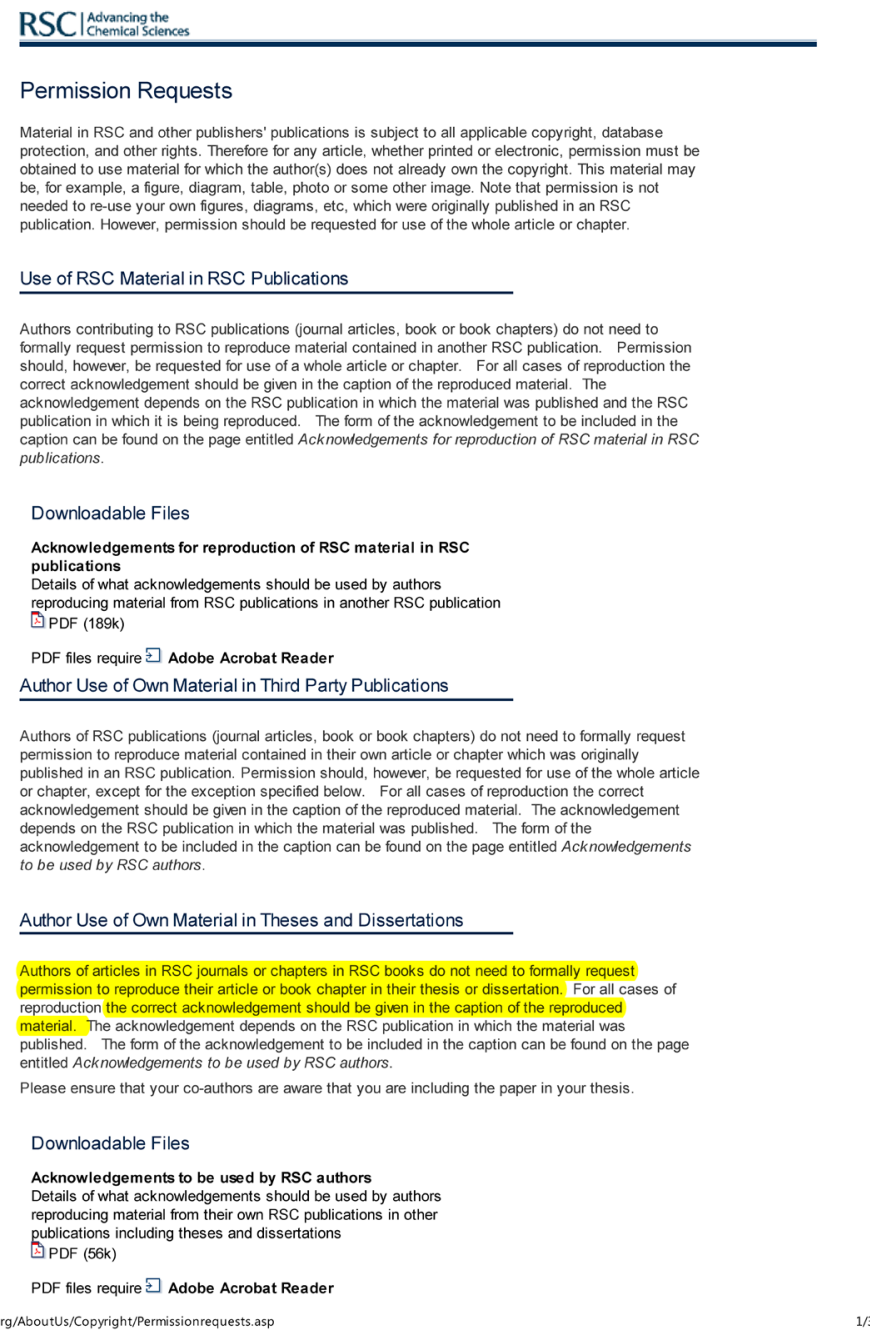

